\title{
Alternative Ultrafiltration Membrane Testing For The SRS Baseline Process
}

\author{
N. R. Mann \\ R. S. Herbst \\ T.G. Garn \\ M. R. Poirier \\ S. D. Fink
}

June 2004

Idaho National Engineering and Environmental Laboratory Bechtel BWXT Idaho, LLC 



\title{
Alternative Ultrafiltration Membrane Testing for the SRS Baseline Process
}

\author{
N. R. Mann \\ R. S. Herbst \\ T. G. Garn \\ Idaho National Engineering and Environmental Laboratory \\ Idaho Falls, ID \\ M. R. Poirier \\ S. D. Fink \\ Savannah River National Laboratory \\ Westinghouse Savannah River Company \\ Aiken, SC
}

June 2004

Idaho National Engineering and Environmental Laboratory

Idaho Falls, Idaho 83415

Prepared for the

U.S. Department of Energy

Under DOE Idaho Operations Office

Contract DE-AC07-99ID13727 



\section{Alternative Ultrafiltration Membrane Testing for the SRS Baseline Process \\ INEEL/EXT-04-01933}

June 2004

\section{Authors}

N. R. Mann, INEEL

Date

R. S. Herbst, INEEL

Date

T. G. Garn, INEEL

Date

M. R. Poirier, SRNL

Date

S. D. Fink, SRNL

Date

\section{Customers}

C. E. Miller, EM-21, Office of Cleanup Technologies

Date

H. D. Harmon, SPP Technology Development Manager

Date

P. C. Suggs, DOE Technology Development Lead

Date

W. D. Kerley, Manager, Actinide Removal Process (SRNL)

Date

R. H. Spires, Manager, Salt Disposition Engineering (SRNL)

Date

S. J. Robertson, Manager, Closure Process Development Group (SRNL)

Date 



\section{ABSTRACT}

The ability to more rapidly process high-level waste sludge and supernate, without sacrificing cost savings, continues to be a crucial challenge facing the Savannah River Site (SRS). There has, to date, not been any extensive investigation of alternative filter technologies for the SRS baseline process. To address this problem, a focused investigation into alternative, state-of-the art filtration technologies to facilitate the strontium and actinide removal process, which can be cost effectively implemented in existing facilities and current equipment designs, was completed. Filter technologies manufactured by Mott $(0.1 \mu \mathrm{m}$ and $0.5 \mu \mathrm{m})$ Graver $(0.07 \mu \mathrm{m})$, Pall $(0.1 \mu \mathrm{m}$ and $0.8 \mu \mathrm{m})$ and GKN $(0.1$

$\mu \mathrm{m})$ were evaluated. Membranes had a nominal inside diameter of $3 / 8$ inches and an active membrane length of 2 feet. The investigation was performed in two phases. The first phase of testing evaluated the consistency or variability in flux through the different membranes using water and a standard $5.0 \mathrm{wt} \%$ strontium carbonate slurry. The second phase of testing evaluated the achievable permeate flux and clarity through the various membranes using the SRS average salt supernate simulant at solids loadings of 0.06, 0.29 and $4.5 \mathrm{wt} \%$. Membrane variation data indicate that membranes having an asymmetric ceramic coating (Pall $0.1 \mu \mathrm{m}$ and Graver $0.07 \mu \mathrm{m}$ ), typically displayed the lowest variability with water. Membranes without a ceramic asymmetric coating (Mott $0.5 \mu \mathrm{m}$ and GKN $0.1 \mu \mathrm{m})$ displayed the highest variability. This is most likely associated with the experimental uncertainties in measuring large volumes of permeate in a short amount of time and to the impact of impurities in the water. In general, variability ranging from $4-56 \%$ was observed when using water for all membranes. In the case of variation testing using strontium carbonate, variability decreased to $3-12 \%$. In addition, membrane structure or composition had little effect on the variability. Data obtained from SRS simulant testing, indicate that membranes having a ceramic asymmetric coating (Graver $0.07 \mu \mathrm{m}$, Pall $0.1 \mu \mathrm{m}$ ), typically achieved the highest average steady state fluxes for all solution concentrations evaluated. In general, the Graver $0.07 \mu \mathrm{m}$ and Pall $0.1 \mu \mathrm{m}$ membranes achieved fluxes approximately 13 to 21 percent higher than those observed with the baseline Mott $0.1 \mu \mathrm{m}$ membrane using the SRS simulant at solids loadings of 0.29 and $4.5 \mathrm{wt} \%$. Membranes without a ceramic asymmetric coating (GKN, Mott) achieved the lowest average steady state fluxes. It is postulated that small particles present in solution were unable to penetrate the ceramic layer, thus producing surface filtration where the filter cake acts as the filter medium. Conversely, membranes without the asymmetric ceramic coating were susceptible to the small particles present in solution penetrating into the internal pore structure of the membrane, thus producing depth filtration where the porosity is greatly reduced by particles trapped within the interstices of the internal structure. Turbidity data indicate that permeate from the alternative membranes provided reduced or equivalent turbidity measurements when compared to the baseline $0.1 \mu \mathrm{m}$ Mott membrane. 


\section{CONTENTS}

ABSTRACT

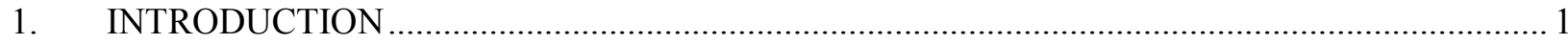

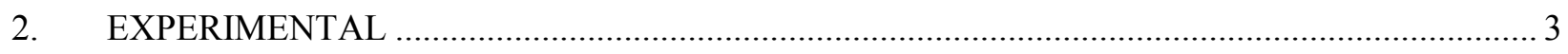

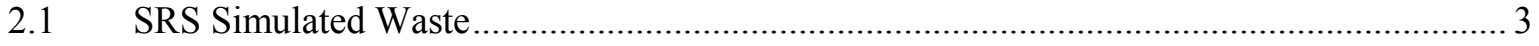

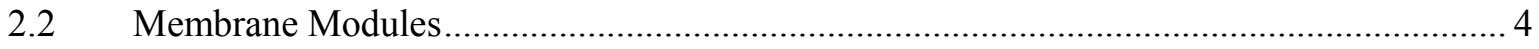

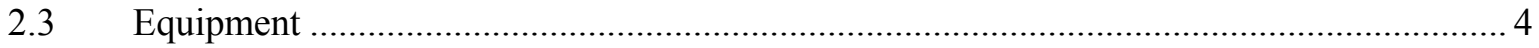

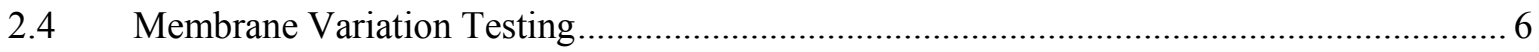

2.5 Experimental Evaluation of Flux with Simulated SRS Solids ........................................ 8

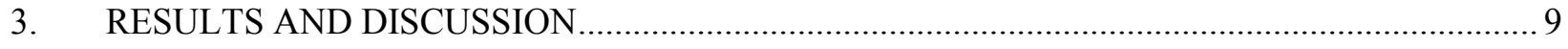

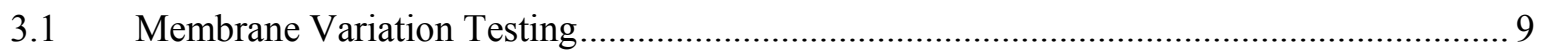

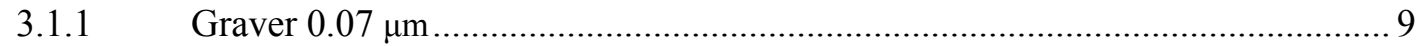

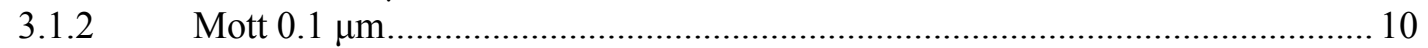

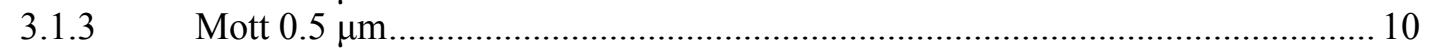

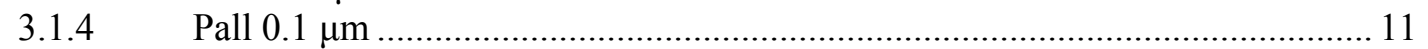

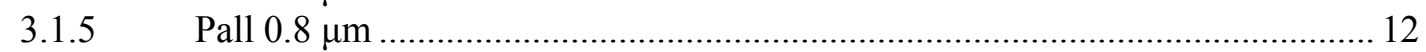

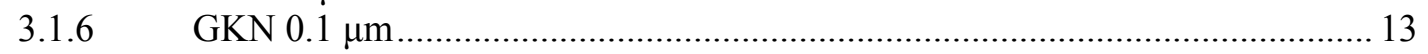

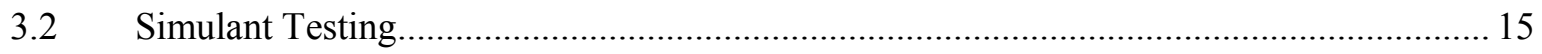

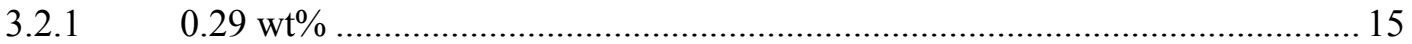

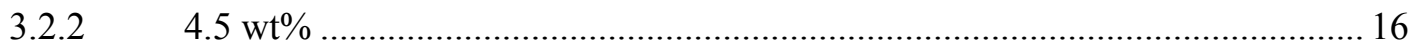

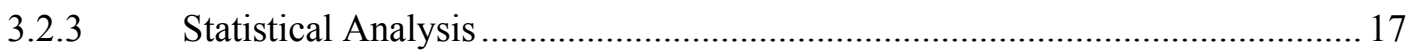

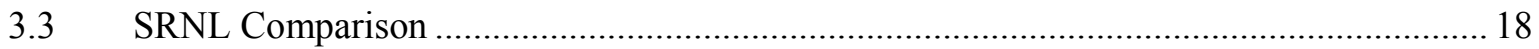

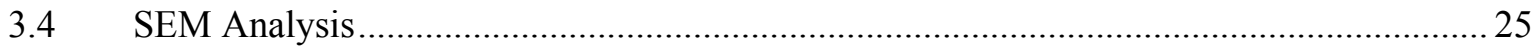

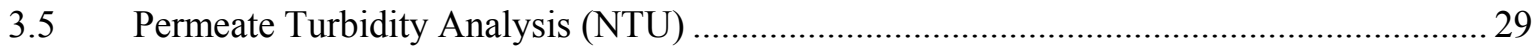

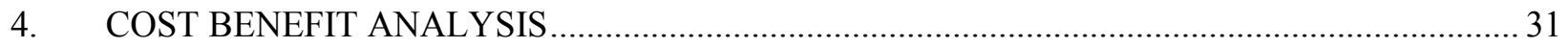

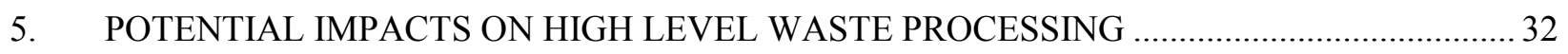

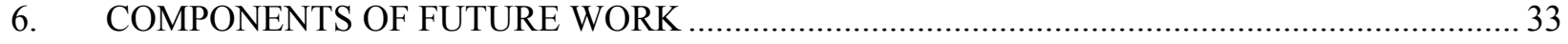

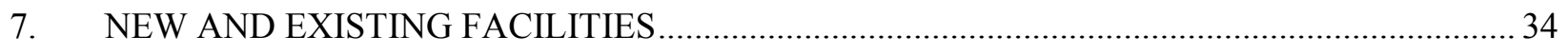

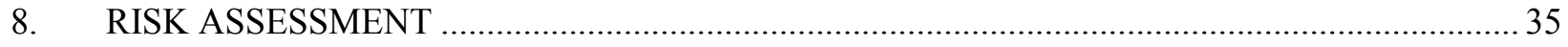

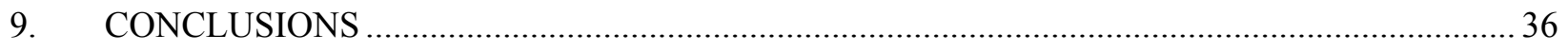

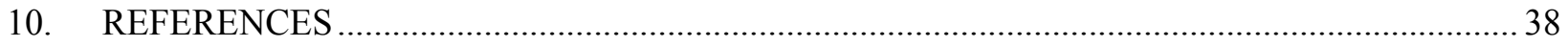




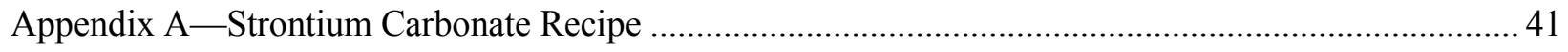

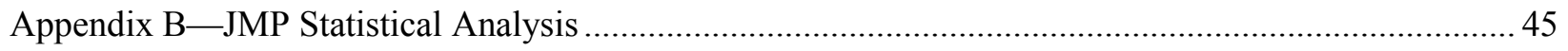

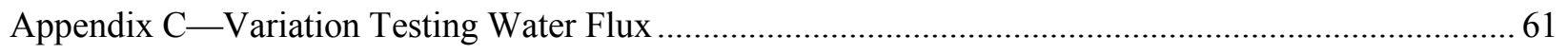

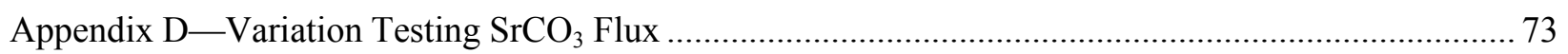

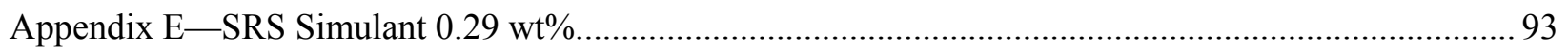

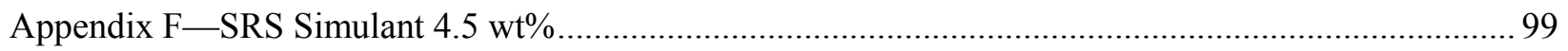

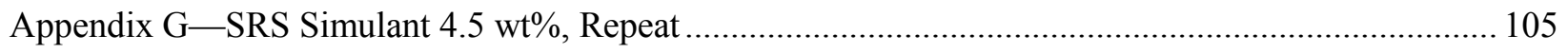

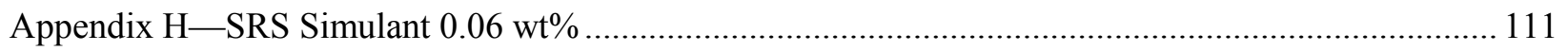

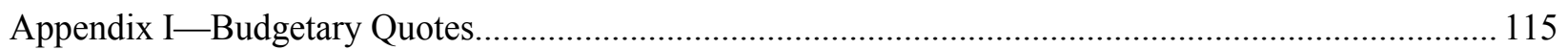

\section{FIGURES}

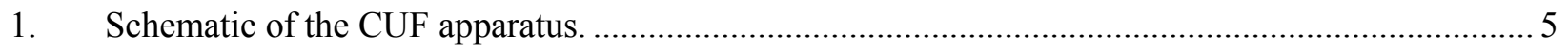

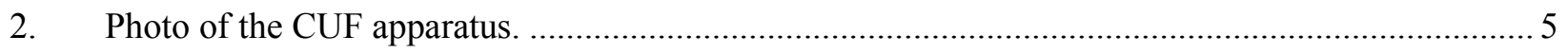

3. Fluxes for five Graver $0.07 \mu \mathrm{m}$ membranes are compared for the pristine, preconditioned,

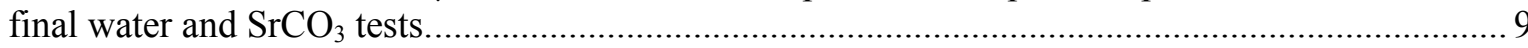

4. Fluxes for five Mott $0.1 \mu \mathrm{m}$ membranes are compared for the pristine, preconditioned, final

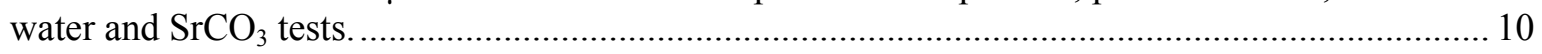

5. Fluxes for five Mott $0.5 \mu \mathrm{m}$ membranes are compared for the pristine, preconditioned, final

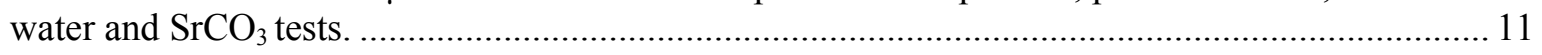

6. Fluxes for five Pall $0.1 \mu \mathrm{m}$ membranes are compared for the pristine, preconditioned, final water and $\mathrm{SrCO}_{3}$ tests.

7. Fluxes for five Pall $0.8 \mu \mathrm{m}$ membranes are compared for the pristine, preconditioned, final water and $\mathrm{SrCO}_{3}$ tests.

8. Fluxes for five GKN $0.1 \mu \mathrm{m}$ membranes are compared for the pristine, preconditioned, final water and $\mathrm{SrCO}_{3}$ tests.

9. The average steady-state flux for the five membranes using the $0.29 \mathrm{wt} \% \mathrm{SRS}$ simulant.............. 16

10. The average steady-state flux for the five membranes using the $4.5 \mathrm{wt} \%$ SRS simulant................ 17

11. Flux as a function of axial velocity for the Mott $0.1 \mu \mathrm{m}$ membrane at $4.5 \mathrm{wt} \%$ for tests performed at the INEEL and SRNL (FRED Facility). 
12. Average steady-state for the Mott $0.1 \mu \mathrm{m}$ (FRED facility), Mott $0.1 \mu \mathrm{m}$ (INEEL), Graver $0.07 \mu \mathrm{m}$ and Pall $0.1 \mu \mathrm{m}$ membranes using the SRS simulant at $0.06 \mathrm{wt} \%$ at $35^{\circ} \mathrm{C}$.

13. Average steady-state flux for the Mott $0.1 \mu \mathrm{m}$ (FRED Facility), Mott $0.1 \mu \mathrm{m}$ (INEEL), Graver $0.07 \mu \mathrm{m}$ and Pall $0.1 \mu \mathrm{m}$ membranes using the SRS simulant at $4.5 \mathrm{wt} \%$ at $35^{\circ} \mathrm{C}$.

14. Focused Beam Reflectance Measurement (FBRM) of slurry samples........................................ 23

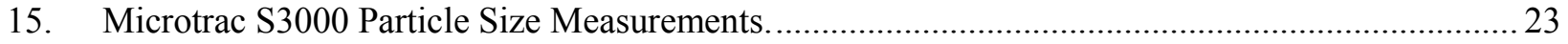

16. Particle size data collected for the as-received SRS solids and slurry samples obtained at the completion of the $0.29 \mathrm{wt} \%$ simulant tests for each membrane.

17. Particle size data collected for the as-received SRS solids and slurry samples obtained at the completion for the $4.5 \mathrm{wt} \%$ simulant tests for each membrane. .25

18. SEM micrograph of the Graver $0.07 \mu \mathrm{m}$ membrane at 1000X magnification.............................26

19. SEM micrograph of the Mott $0.1 \mu \mathrm{m}$ membrane at 2000X magnification. .................................. 27

20. SEM micrograph of the Mott $0.5 \mu \mathrm{m}$ membrane at 2000X magnification. .................................... 27

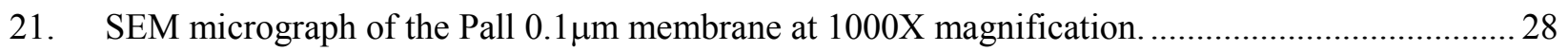

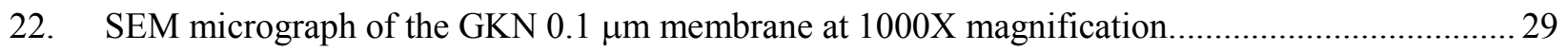

\section{TABLES}

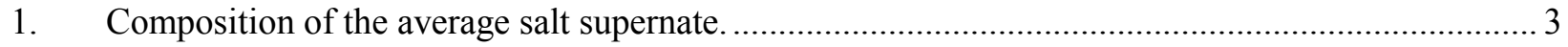

2. Test matrix for evaluating flux through the different membranes............................................... 7

3. Summary of the average water and $\mathrm{SrCO}_{3}$ flux data for the different membranes....................... 15

4. Experimental differences for simulant tests performed with the Mott $0.1 \mu \mathrm{m}$ at the INEEL and SRNL (FRED facility)

5. The average Nephelometric Turbidity Units (NTU) and standard deviation for permeate samples for all membranes tested at 0.29 and $4.5 \mathrm{wt} \%$ 30

6. Budgetary quote for retrofit into the existing crossflow filter located in 512-S. 


\section{Alternative Ultrafiltration Membrane Testing for the SRS Baseline Process}

\section{INTRODUCTION}

The ability to more rapidly process high-level waste sludge and supernate, without sacrificing cost savings, continues to be a crucial challenge facing the Savannah River Site (SRS). To address this problem, a focused investigation into unique, state-of-the art filtration technologies to facilitate the strontium and actinide removal process, which can be cost effectively implemented in existing facilities and current equipment designs, were evaluated. Specifically, the goal of this effort was to evaluate achievable permeate flux and clarity through membranes of similar structure and composition that are currently available commercially from different manufacturers as alternatives to the Mott product used in the current baseline. The Idaho National Engineering and Environmental Laboratory (INEEL) and the Savannah River National Laboratory (SRNL) received funding from the Department of Energy - Head Quarters (DOE-HQ), Office of Cleanup Technologies (EM-21), via the National Energy Technology Laboratory (NETL), to evaluate alternative filter media. The baseline crossflow unit operation uses filtration membranes provided by Mott Metallurgical as the prescribed filtration media. This work experimentally examined crossflow filtration media manufactured by Pall, GKN, Graver and Mott. The Mott, Graver and GKN media are all nominally rated at approximately $0.1 \mu \mathrm{m}$ pore size, i.e. equivalent to the recommended Mott baseline. A Mott $0.5 \mu \mathrm{m}$ membrane was also evaluated to provide a complete comparison of filter media. The Pall media were absolute rated at 0.1 and 0.8 , respectively.

The current baseline treatment process at SRS for strontium and actinide removal involves sorption on particulate Monosodium Titanate (MST) followed by crossflow filtration to remove entrained sludge and radionuclide-containing MST solids. Not only is this same process incorporated in the baseline approach to process all of the existing wastes through the Salt Waste Processing Facility (SWPF), but it is also the baseline technology associated with the accelerated treatment option. The basic premise of the accelerated option is to segregate the waste by type and selectively process the different types. In the accelerated option, some wastes require strontium and actinide removal from the supernate liquid; this would be facilitated by sorption on particulate MST. Crossflow filtration would be used to concentrate the radionuclide-containing fraction (both sludge and MST solids are present) for vitrification as High-Level Waste (HLW) in the existing Defense Waste Processing Facility (DWPF). Treatment of wastes by MST and crossflow filtration assumes the use of existing facilities (such as Building 512-S); however, due to limited space in the facility, the filtration equipment must provide the highest possible processing rates.

The Mott product was extensively studied, at both the experimental and pilot scales, with regard to flux and cleanability using simulated and actual SRS wastes. ${ }^{(1-12)}$ Fluxes through the Mott membranes are well documented and the current design basis is $0.02 \mathrm{gpm} / \mathrm{square}$ foot of filter area $\left(\mathrm{gpm} / \mathrm{ft}^{2}\right)$, which has been used to size and cost the crossflow equipment in SWPF. Although the Mott product has undergone extensive study, little attention has been given to the application of other similar, commercially available products for the SRS-specific application. Higher processing rates, hence increased performance, may be obtained by a simple substitution of a different manufacturer's membrane for the Mott product. There is

experimental evidence ${ }^{(13,14)}$ with other streams that these alternative, commercially available membranes have the potential to provide permeate fluxes that are measurably higher than the current Mott design basis of $0.02 \mathrm{gpm} / \mathrm{ft}^{2}$. An equally important aspect of the alternative membranes is that they must produce permeates of at least the same clarity (as determined by turbidity) as the Mott membranes. An increase in filter flux with the relatively simple change in membrane specification would have two positive impacts on the baseline process: 1) higher flux translates to faster processing rates in the same size crossflow equipment, thus resulting in accelerated throughput or processing rates, and 2) higher flux equates to 
lower membrane surface area for the same throughput, thereby reducing crossflow equipment size. In reality, a balance of these two advantages is possible, but such a balance would be established based on the priorities of the process and an engineering evaluation. An additional consideration in the selection of the commercially available membranes from each manufacturer is the consistency or variability in fluxes through the new membranes due to porosity differences or residual solid impurities from the manufacturing processes. An additional effort was included in this work to quantify the variations in flux through the different membranes samples. 


\section{EXPERIMENTAL}

\subsection{SRS Simulated Waste}

The SRS simulant used in this testing was prepared according to methods developed by the Savannah River National Laboratory (SRNL) for the preparation of the SRS average salt supernate solution. The simulated SRS sludge and MST solids were provided directly from SRNL at a solids loading of approximately $7.25 \mathrm{wt} \%$. The simulated SRS supernate solution was prepared at the INEEL using a standard recipe provided by SRNL. The proper proportions of MST and sludge were diluted to the required feed solids concentration for testing $(0.06,0.29$ and $4.5 \mathrm{wt} \%)$ with the supernate solution. Twenty-one liters of each waste loading was prepared for testing to provide fresh feed solution for each membrane test. Particle size distribution analysis of the feed before and after testing was performed and will be discussed in a subsequent section. The composition of the supernate solution is indicated in Table 1 for a 1-liter batch.

Table 1. Composition of the average salt supernate.

\begin{tabular}{|c|c|c|c|c|}
\hline Component & Source & $\begin{array}{l}\text { Molecular Weight } \\
\quad(\mathrm{g} / \mathrm{mole})\end{array}$ & $\begin{array}{c}\text { Target } \\
\text { Concentration } \\
\text { (molar) }\end{array}$ & $\begin{array}{l}\text { Amount } \\
\text { Required } \\
\text { (grams/L) }\end{array}$ \\
\hline $\mathrm{K}^{+}$ & $\mathrm{KNO}_{3}$ & 101.1 & 0.015 & 1.517 \\
\hline $\mathrm{Cs}^{+}$ & $\mathrm{CsNO}_{3}$ & 194.92 & 0.00014 & 0.027 \\
\hline $\mathrm{OH}^{-}$ & $\mathrm{NaOH}$ & 40.00 & 1.91 & 126.40 \\
\hline $\mathrm{NO}_{3}^{-}$ & $\mathrm{NaNO}_{3}$ & 84.99 & 2.14 & 101.55 \\
\hline $\mathrm{NO}_{2}^{-}$ & $\mathrm{NaNO}_{2}$ & 69.00 & 0.52 & 35.88 \\
\hline $\mathrm{AlO}_{2}^{-}$ & $\mathrm{Al}\left(\mathrm{NO}_{3}\right)_{3} \cdot 9 \mathrm{H}_{2} \mathrm{O}$ & 375.14 & 0.31 & 116.29 \\
\hline $\mathrm{CO}_{3}{ }^{2-}$ & $\mathrm{Na}_{2} \mathrm{CO}_{3} \cdot \mathrm{H}_{2} \mathrm{O}$ & 124.01 & 0.16 & 19.84 \\
\hline $\mathrm{SO}_{4}^{2-}$ & $\mathrm{Na}_{2} \mathrm{SO}_{4}$ & 142.04 & 0.15 & 21.31 \\
\hline $\mathrm{Cl}^{-}$ & $\mathrm{NaCl}$ & 58.44 & 0.025 & 1.461 \\
\hline $\mathrm{F}^{-}$ & $\mathrm{NaF}$ & 41.99 & 0.032 & 1.344 \\
\hline $\mathrm{PO}_{4}^{3-}$ & $\mathrm{Na}_{2} \mathrm{HPO}_{4} \cdot 7 \mathrm{H}_{2} \mathrm{O}$ & 268.09 & 0.010 & 2.681 \\
\hline $\mathrm{C}_{2} \mathrm{O}_{4}{ }^{2-}$ & $\mathrm{Na}_{2} \mathrm{C}_{2} \mathrm{O}_{4}$ & 134.00 & 0.008 & 1.072 \\
\hline $\mathrm{SiO}_{3}^{2-}$ & $\mathrm{Na}_{2} \mathrm{SiO}_{3} \cdot 9 \mathrm{H}_{2} \mathrm{O}$ & 284.2 & 0.004 & 1.137 \\
\hline $\mathrm{MoO}_{4}^{2-}$ & $\mathrm{Na}_{2} \mathrm{MoO}_{4} \cdot 2 \mathrm{H}_{2} \mathrm{O}$ & 241.95 & 0.0002 & 0.048 \\
\hline Tributyl Phosphate & & 266.00 & & $5.0 \mathrm{E}-04$ \\
\hline Dibutyl Phosphate & & 210.00 & & $2.5 \mathrm{E}-02$ \\
\hline Monobutyl Phosphate & & 154.00 & & $2.5 \mathrm{E}-02$ \\
\hline n-Butanol & & 74.00 & & $2.0 \mathrm{E}-03$ \\
\hline Sodium Formate & & 68.00 & & 1.5 \\
\hline Water & & & & 827.9 \\
\hline Total Weight & & & & 1258.0 \\
\hline
\end{tabular}




\subsection{Membrane Modules}

The commercially available membranes evaluated in this study were selected based on similar specifications and materials of construction to the baseline Mott products. Furthermore, any tentative replacement to the baseline membrane would need to be predicated on a very similar design configuration for the specified product to facilitate a relative simple change without a major reconfiguration of the filtration equipment. The selection criteria included existing commercial availability, a $0.1 \mu \mathrm{m}$ nominal and/or absolute particle size cutoff rating, sintered stainless steel composition, and modules available in nominal 3/8" tubular form. Membranes tested include:

- $\quad$ Mott Metallurgical (USA): Two Mott products were obtained for testing, $0.1 \mu \mathrm{m}$ and $0.5 \mu \mathrm{m}$. Both Mott products are symmetric in design comprising solely of sintered stainless steel. The wall thickness for both Mott products was 0.062 inches. Extensive work has been performed on both Mott products throughout the DOE complex. The Mott $0.1 \mu \mathrm{m}$ product was recently chosen as the current baseline. For comparative purposes and completeness of the evaluation, a $0.5 \mu \mathrm{m}$ Mott membrane was also included in the experimental program. The $0.5 \mu \mathrm{m}$ Mott membrane was the previous baseline. Evaluation of these membranes is necessary as a baseline for all data generated in this work and provides a valuable and necessary point of comparison with numerous studies by other researchers in similar efforts.

- $\quad$ GKN (Germany): asymmetric, sintered stainless steel substrate with a thinner layer of sintered metal deposited on the surface. The GKN membranes obtained for testing had a nominal pore size of $0.1 \mu \mathrm{m}$. The wall thickness for the GKN membrane was 0.079 inches

- Graver Technologies (USA): asymmetric, thin layer of sintered titania $\left(\mathrm{TiO}_{2}\right)$ deposited on sintered stainless steel substrate. The Graver membranes obtained from testing had a nominal pore size of $0.07 \mu \mathrm{m}$. The wall thickness for the Graver membrane was 0.055 inches.

- $\quad$ Pall Corp. (USA): Two Pall products were purchased for testing: $0.8 \mu \mathrm{m}$ and $0.1 \mu \mathrm{m}$. The $0.1 \mu \mathrm{m}$ product is absolute rated at $0.1 \mu \mathrm{m}$ and is an asymmetric membrane comprised of a sintered zirconia $\left(\mathrm{ZrO}_{2}\right)$ layer on a sintered stainless steel support. The $0.8 \mu \mathrm{m}$ product is absolute rated at $0.8 \mu \mathrm{m}$ and is symmetric comprising solely of sintered stainless steel. The wall thickness for both Pall products is 0.035 inches.

The membranes modules obtained for evaluation consisted of a nominal 3/8-inch inside diameter with a single section of active membrane tube, 2 feet in length. Membranes modules were modified by the respective manufacture (per INEEL instruction) to insure compatibility with the test rigs. These modifications included welding VCO end fittings (O-ring face seal fittings) to the tubes and installing permeate and pressure ports.

\subsection{Equipment}

The Cells Unit Filter (CUF), depicted schematically in Figure 1 and pictorially in Figure 2, was used for flux measurements with the commercially available membrane modules. ${ }^{(15)}$ Two identical and fully operational CUF systems exist for testing simulated (non-radioactive) wastes at the INEEL. The system consists of a 4 liter feed vessel, which feeds a modified Oberdorfer progressive cavity pump driven by a variable speed direct current (DC) motor. The feed solution (water, cleaning solution, or simulated waste) is recirculated from the feed vessel through a flowmeter, heat exchanger, and the interior of the tubular filter membrane, then back to the feed vessel. Maximum volumetric flow through the system is $\sim 9$ gpm, depending on the pressure head developed at the pump outlet. The discharge throttle valve, located on the discharge side of the filter module, is used to control transmembrane pressure by controlling pump head and flow rate. The permeate side of the membrane is at ambient pressure ( 0 psig) 


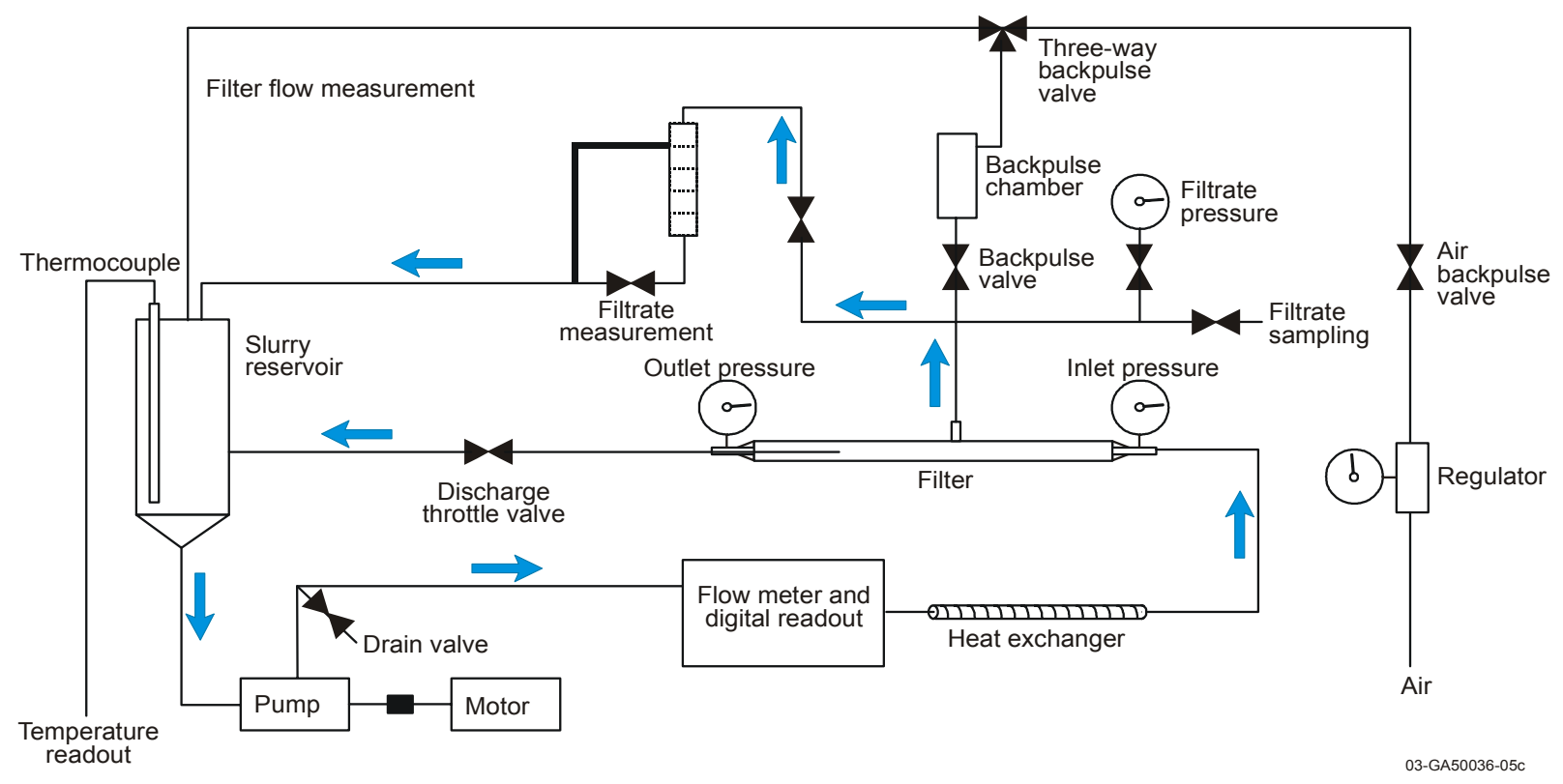

Figure 1. Schematic of the CUF apparatus.

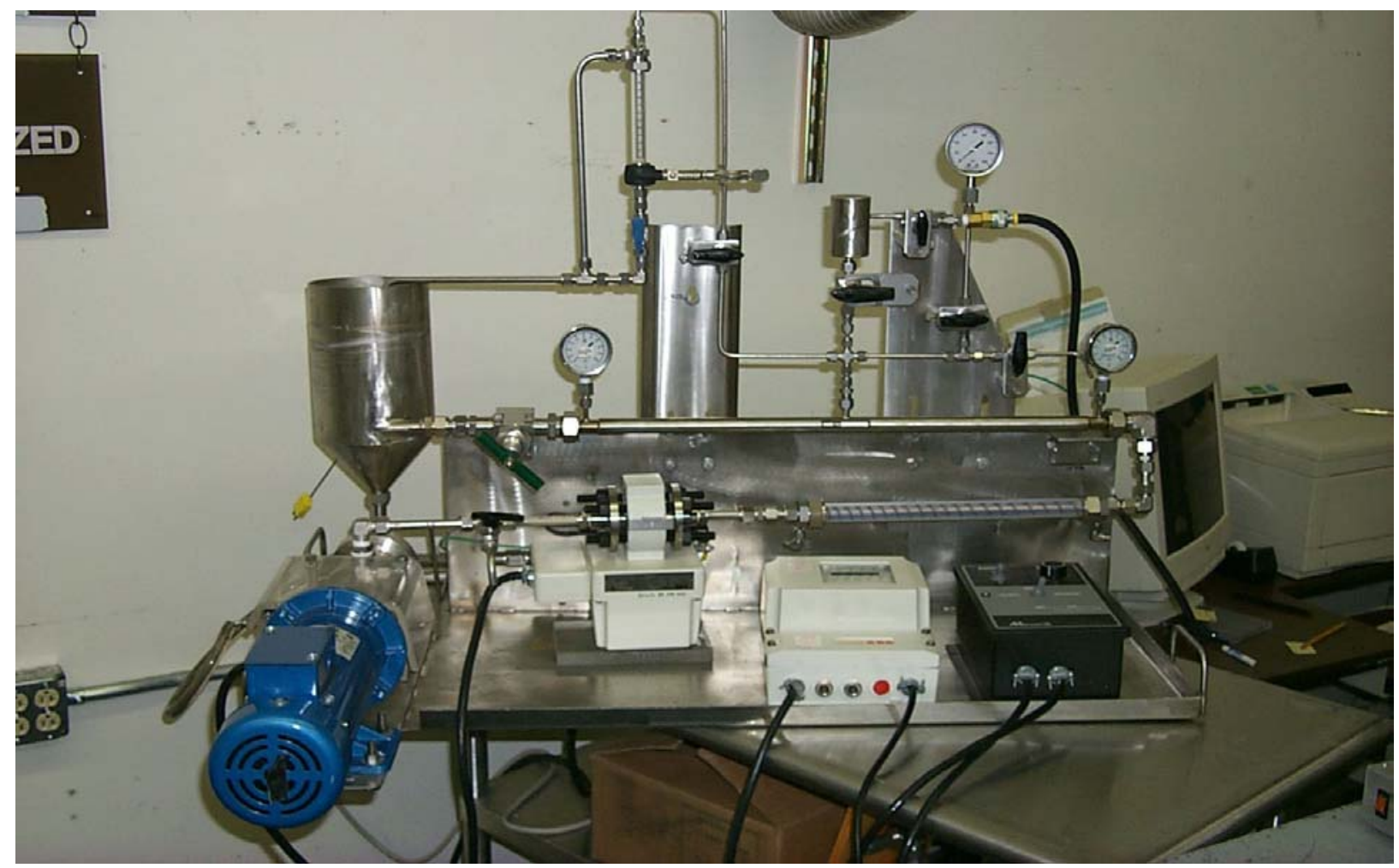

Figure 2. Photo of the CUF apparatus. 
and transmembrane pressures of up to 100 psig can be easily achieved with this arrangement. The CUF is designed to accommodate a two-foot length of active membrane. The design incorporates a back-pulse system that pressurizes permeate (overpressure of up to $100 \mathrm{psig}$ ) collected in the small back-pulse vessel. The small volume of pressurized permeate can be routed back to the permeate side of the membrane module, thereby dislodging or re-suspending filter cake and solids entrained in the membrane surface from the feed side of the membrane. The back pulse system includes the necessary manual valves to collect, pressurize, and back-pulse the filter membrane. The permeate exiting on the low pressure side of the membrane was collected in the sample holder, routed through a graduated cylinder that can be used to manually measure permeate flux, and is typically routed back to the feed vessel. Permeate flux was corrected to $25^{\circ} \mathrm{C}$, using the following equation. ${ }^{(13)}$

$$
\text { Flux }=\frac{P}{A} * C
$$

Where:

$$
\begin{array}{lll}
\text { Flux } & = & \text { permeate flux at } 25^{\circ} \mathrm{C}\left(\mathrm{gpm} / \mathrm{ft}^{2}\right) \\
\mathrm{P} & = & \text { permeate flow rate }(\mathrm{gpm}) \\
\mathrm{A} & = & \text { filter surface area }\left(\mathrm{ft}^{2}\right) \\
\mathrm{C} & = & \text { temperature correction factor }=\mathrm{e}^{\left(2500^{*}((1 /(273+\mathrm{T}))-(1 / 298))\right)} \\
\mathrm{T} & = & \text { slurry/permeate temperature in degrees Celsius }
\end{array}
$$

The temperature correction factor corrects flux back to an equivalent flux at $25^{\circ} \mathrm{C}$ and accounts for changes in fluid viscosity and surface tension. Additional parameters recorded during testing include recirculation flow, axial velocity, membrane inlet pressure, membrane outlet pressure, permeate pressure, and slurry temperature.

\subsection{Membrane Variation Testing}

An important consideration in the selection of the commercially available membranes from each manufacturer is the consistency or variability in fluxes through the new membranes due to porosity differences or residual solid impurities from the manufacturing processes. Testing was used for the specific purpose of observing the variability within a specific membrane group or manufacturer and not as a basis of comparison between groups or manufactures.

An effort to quantify the variations in flux through the different membranes samples was completed. Five identical membrane modules were obtained from each respective manufacturer and fluxes were evaluated through the different membrane samples using the CUF apparatus. Membranes were evaluated for variation using the following test sequence.

1. Measure pristine water flux (benchmark flux).

2. $\quad$ Perform preconditioning procedure.

3. Re-measure water flux (evaluate potential increase or decrease in flux as a result of preconditioning).

4. Measure flux using standard $5.0 \mathrm{wt} \%$ strontium carbonate solution. 
5. Perform acid rinse using 1.0 $\mathrm{M}$ nitric (in-situ to remove residual strontium carbonate from system).

6. Re-measure water flux (ensure complete removal of residual strontium carbonate).

Water flux variation tests were performed using Nanopure ${ }^{\mathrm{TM}}$ water at $7.0 \mathrm{ft} / \mathrm{sec}$ linear axial velocity (AV) and 10, 20, 30, 40 and 50 psig, transmembrane pressure (TMP), each condition being held for 0.5 hours.

The preconditioning procedure was performed to remove residual manufacturing impurities from the membranes and ensure reproducible "clean water" fluxes were obtained. The preconditioning procedure was performed using $0.1 \mathrm{M}$ sodium hydroxide followed by $1.0 \mathrm{M}$ nitric acid and then $0.5 \mathrm{M}$ oxalic acid. Preconditioning solutions were routed through the system at $9.0 \mathrm{ft} / \mathrm{sec}$ linear axial velocity (AV) and $30 \mathrm{psig}$ TMP for 0.5 hours each. A water rinse was performed between each conditioning solution.

Flux measurements using strontium carbonate $\left(\mathrm{SrCO}_{3}\right.$ precipitate in $\left.0.2 \mathrm{M} \mathrm{NaOH}\right)$ were performed to ensure representative flux under conditions of solids loading. Fluxes measured under load are often more indicative of membrane performance than the clean water flux. The $\mathrm{SrCO}_{3}$ flux test is useful since the particulate slurry can be easily prepared with a narrow particle size distribution (median particle size 3-4 $\mu \mathrm{m}$ ) of solids and residual solids, potentially fouling the membrane, are easily cleaned. The recipe for the strontium carbonate solution is shown in Table 1 of Appendix A. Strontium carbonate flux was measured using a parametric study, indicated in Table 2 . The test conditions used in the parametric study were collaboratively selected by the INEEL and SRNL and are based on historical testing and tentative operating conditions of the Actinide Removal Process (ARP) filtration plant. ${ }^{(12)}$ It should be noted that the parametric conditions were also used in subsequent SRS simulant testing (vide infra). The eleven statistically designed test conditions vary transmembrane pressure (TMP) from 15 to 45 psig and axial velocity (AV) from 4 to $14 \mathrm{ft} / \mathrm{sec}$. Three liters of $5.0 \mathrm{wt} \%$ strontium carbonate solution were used for testing of each membrane.

Table 2. Test matrix for evaluating flux through the different membranes.

\begin{tabular}{ccc} 
Condition & $\begin{array}{c}\text { Axial Velocity } \\
(\mathrm{ft} / \mathrm{sec})\end{array}$ & $\begin{array}{c}\text { Transmembrane Pressure } \\
(\mathrm{psid})\end{array}$ \\
\hline 1 & 9 & 30 \\
2 & 12 & 40 \\
3 & 4 & 30 \\
4 & 9 & 15 \\
5 & 12 & 20 \\
6 & 9 & 30 \\
7 & 6 & 40 \\
8 & 9 & 45 \\
9 & 14 & 30 \\
10 & 6 & 20 \\
11 & 9 & 30 \\
\hline
\end{tabular}




\subsection{Experimental Evaluation of Flux with Simulated SRS Solids}

SRS simulant testing commenced by installing an average or typical membrane module from each membrane manufacturer (as statistically determined from water and strontium carbonate variation testing). Prior to waste addition, simulants were mixed using a Barnant (Series 10) mixer with accompanying stainless steel impeller and stand. Simulants were mixed for 0.25 hours to ensure complete homogeneity of the slurry prior to testing. A Cole-Parmer, Masterflex ${ }^{\circledR}$ peristaltic pump (Model 7518-12) was used for slurry transfer. Approximately 3.5 liters of slurry was used for each membrane test.

Simulant flux was measured using the parametric test matrix, as indicated in Table 2 (vide supra). The test conditions used in the parametric study were collaboratively selected by the INEEL and SRNL. The ranges of process variables to be tested were determined to envelope baseline design conditions of 6$9 \mathrm{ft} / \mathrm{sec}$ axial velocity and $30-40 \mathrm{psig}$ transmembrane pressure.

Aside from permeate flux, the collected analytical data included the particle size distribution (PSD) of suspended solids prior to and following testing and permeate turbidity. PSD analysis was used to ensure consistent and verifiable feed slurries. In addition, the effects of shear and associated particle deagglomeration were also evaluated using PSD analysis. Permeate turbidity analysis was performed by obtaining samples of permeate at test conditions 1,6 and 11, (repeatable test conditions). An approximate $30 \mathrm{~mL}$ sample of permeate was obtained for turbidity analysis using a $\mathrm{Hach}^{\circledR} 2100 \mathrm{P}$ turbidmeter. 


\section{RESULTS AND DISCUSSION}

\subsection{Membrane Variation Testing}

\subsubsection{Graver $0.07 \mu \mathrm{m}$}

A comparison for five $0.07 \mu \mathrm{m}$ Graver membranes is shown in Figure 3. Comparisons are shown for the (as-received) pristine water flux, water flux following the preconditioning sequence, final water flux (following $\mathrm{SrCO}_{3}$ and the nitric acid rinse) and fluxes obtained from the $5.0 \mathrm{wt} \% \mathrm{SrCO}_{3}$ solution. Also shown is the average flux for the respective tests. When referring to the water flux data, an average increase of $30.2 \%$ can be observed following preconditioning. This increase is most evident with the $\mathrm{C}$ membrane. It should be noted that a cleaning procedure is recommended by Graver to remove residual manufacturing impurities. It should also be noted that a $23.9 \%$ reduction in flux was observed following the final water flux.

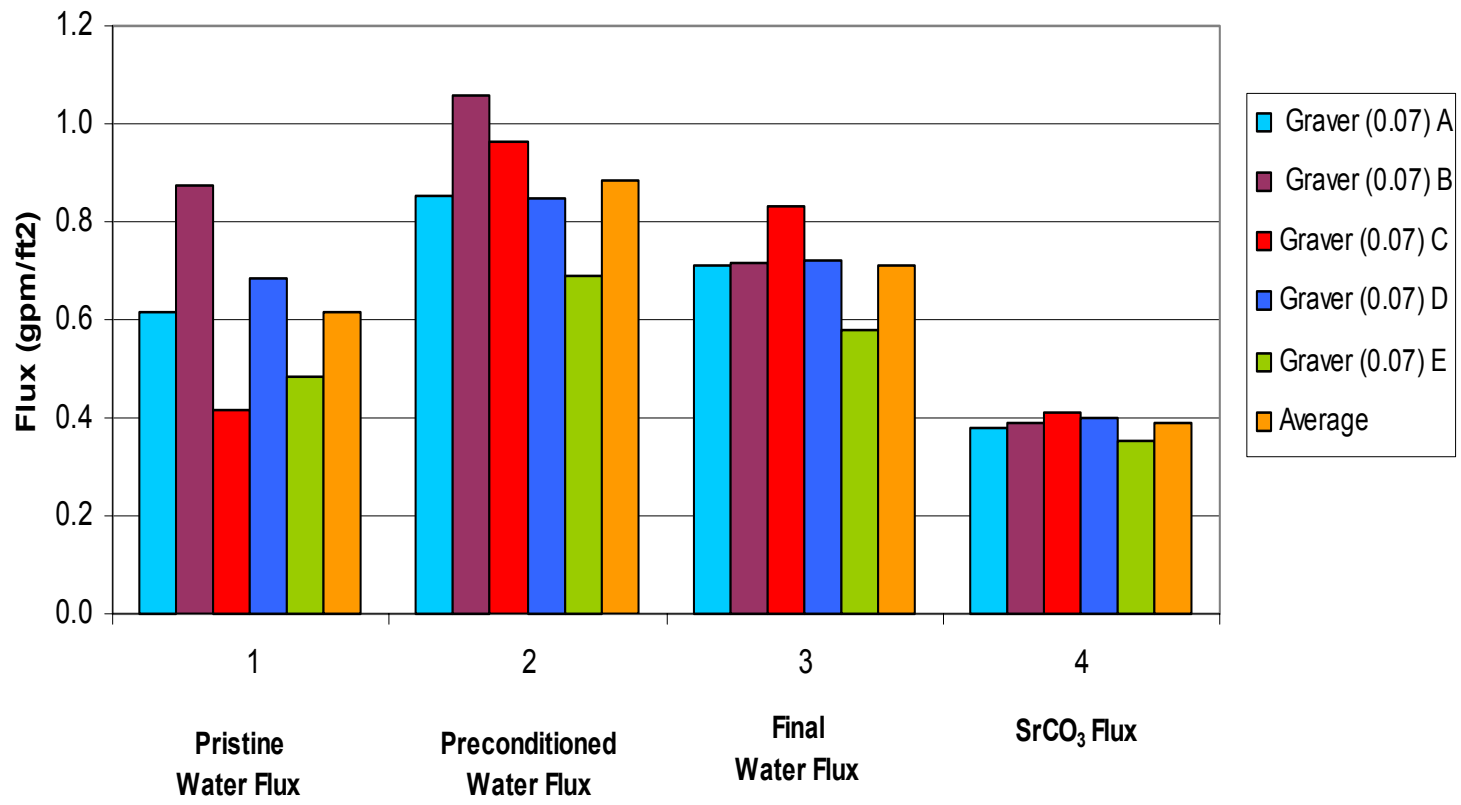

Figure 3. Fluxes for five Graver $0.07 \mu \mathrm{m}$ membranes are compared for the pristine, preconditioned, final water and $\mathrm{SrCO}_{3}$ tests.

Statistical analysis of variance techniques (ANOVA) applied to the complete set of water flux data for these membranes indicates no statistical differences are associated with these five Graver modules: all membranes are the same and none of them can be rejected on statistical grounds. In general, ANOVA analysis indicates that any of the five membrane modules could be chosen as the most representative for testing with the SRS simulated wastes. It should be noted that Graver module E had a very slight leak at the weld around the permeate port on the housing. The leak was not sufficient to impact the measurement of flux; however, the use of the E module was rejected based on the leak. 


\subsubsection{Mott $0.1 \mu \mathrm{m}$}

A comparison for five $0.1 \mu \mathrm{m}$ Mott membranes is shown in Figure 4. Comparisons are shown for the (as-received) pristine water flux, water flux following the preconditioning sequence, final water flux (following $\mathrm{SrCO}_{3}$ and nitric acid rinse) and fluxes obtained from the $5.0 \mathrm{wt} \% \mathrm{SrCO}_{3}$ solution. Also shown is the average flux for the respective tests. The water permeation rate through the Mott membranes was quite consistent for the pristine (as-received) membranes and after preconditioning. However, an average increase in flux of $5.7 \%$ can be observed following preconditioning. The data indicate that the water permeation rates through the Mott $0.1 \mu \mathrm{m}$ membranes were relatively high. Any variability associated with water flux is most likely due to experimental error as a result of the high permeation rates.

Statistical analysis of variance techniques (ANOVA) applied to the complete set of water flux data for the Mott $0.1 \mu \mathrm{m}$ membranes indicate no statistical differences associated with the five modules: all membranes are the same and none of them can be rejected on statistical grounds. In general, ANOVA analysis indicates that any of the five membrane modules could be chosen for testing with the SRS simulated wastes.

\subsubsection{Mott $0.5 \mu \mathrm{m}$}

A comparison for five Mott $0.5 \mu \mathrm{m}$ membranes is shown in Figure 5. Comparisons are shown for the (as-received) pristine water flux, water flux following the preconditioning sequence, final water flux (following $\mathrm{SrCO}_{3}$ and nitric acid rinse) and fluxes obtained from the $5.0 \mathrm{wt} \% \mathrm{SrCO}_{3}$ solution. Also shown is the average flux for the respective tests.

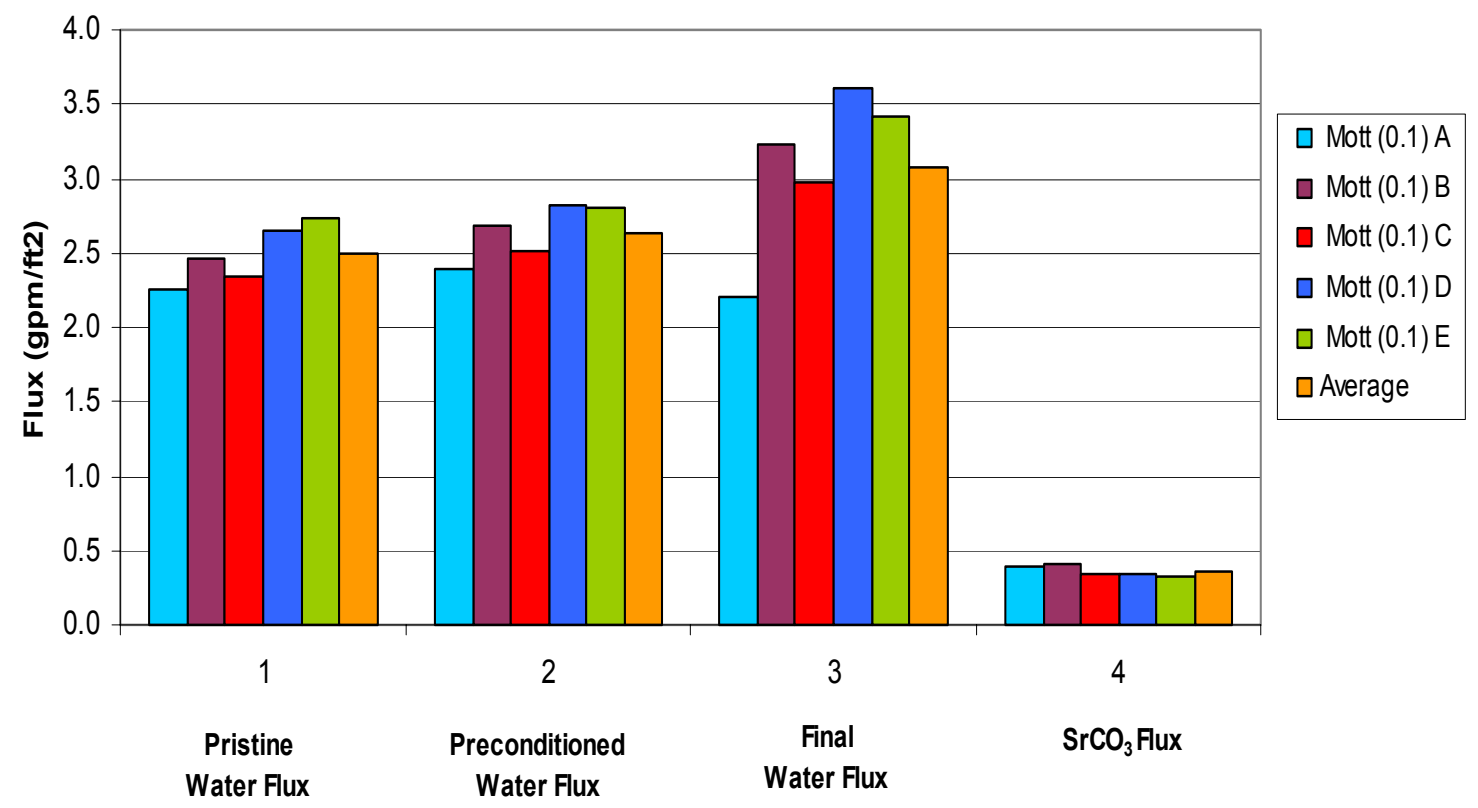

Figure 4. Fluxes for five Mott $0.1 \mu \mathrm{m}$ membranes are compared for the pristine, preconditioned, final water and $\mathrm{SrCO}_{3}$ tests. 


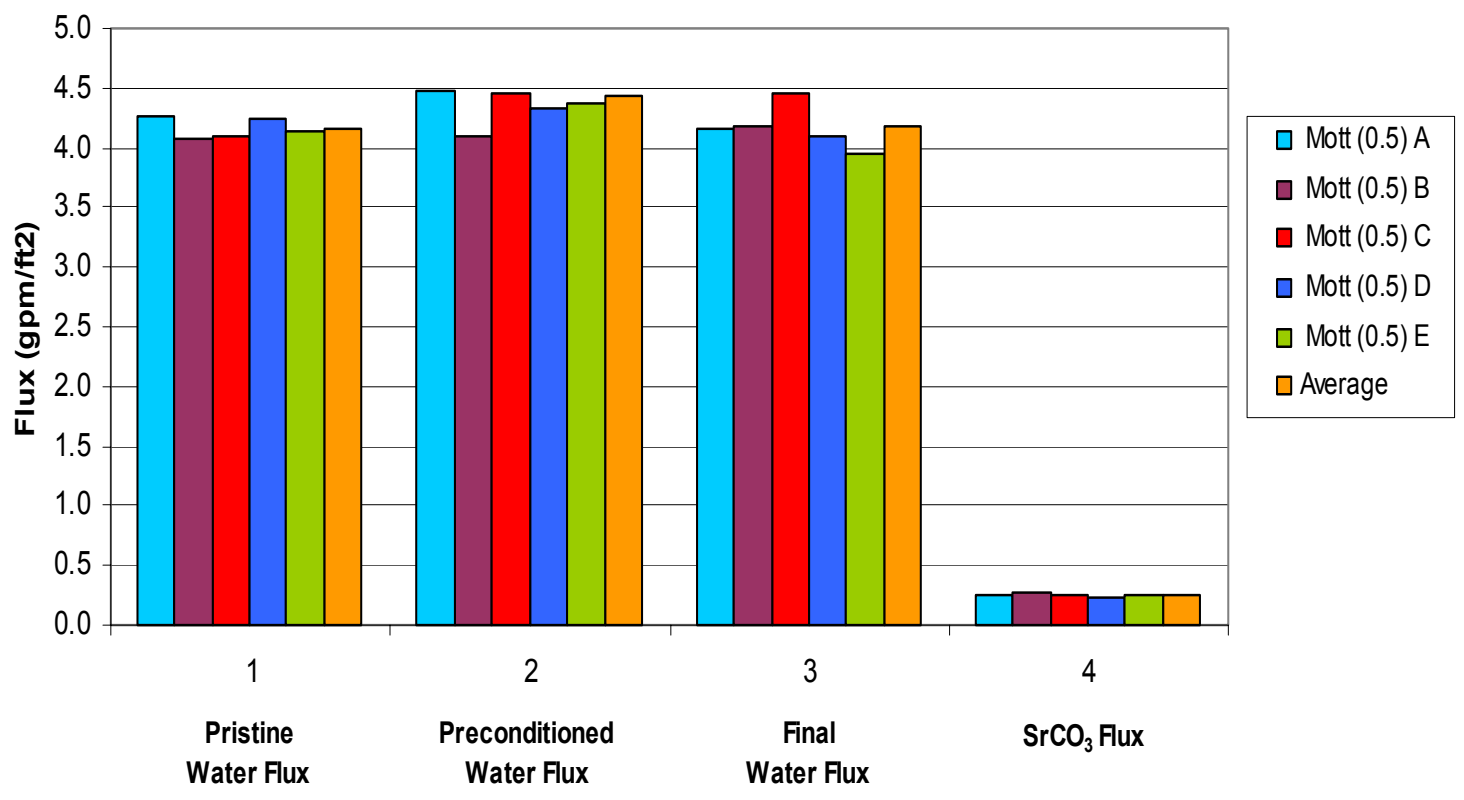

Figure 5. Fluxes for five Mott $0.5 \mu \mathrm{m}$ membranes are compared for the pristine, preconditioned, final water and $\mathrm{SrCO}_{3}$ tests.

The water permeation rate through the Mott $0.5 \mu \mathrm{m}$ membranes was quite consistent for the pristine (as-received) membranes and after preconditioning. An overall increase in flux of $4.0 \%$ can be observed following preconditioning. Data obtained for the final water flux indicate an average decrease of $4.2 \%$ over the preconditioned water flux. Average water permeation rates for the pristine and final water fluxes are nearly identical. Water permeation rates through the Mott $0.5 \mu \mathrm{m}$ membranes were nearly the highest among the membranes tested. As a result, a different measurement technique was adopted to handle the increased capacity. The variability associated with water flux is most likely due to experimental error related to the high water permeation rates.

Statistical analysis of variance techniques (ANOVA) applied to the complete set of water flux data for these membranes indicates no statistical differences are associated with the five Mott $0.5 \mu \mathrm{m}$ modules: all membranes are the same among respective pore sizes and none of them can be rejected on statistical grounds. In general, ANOVA analysis indicates that any of the five membrane modules could be chosen for testing with the SRS simulated wastes.

\subsubsection{Pall $0.1 \mu \mathrm{m}$}

Fluxes for five Pall $0.1 \mu \mathrm{m}$ membranes is shown in Figure 6. Comparisons are shown for the (asreceived) pristine water flux, water flux following the preconditioning sequence, final water flux (following $\mathrm{SrCO}_{3}$ and nitric acid rinse) and fluxes obtained from the $5.0 \mathrm{wt} \% \mathrm{SrCO}_{3}$ solution. Also shown is the average flux for the respective tests. The water permeation rate through the Pall membranes was quite consistent for all sets of water flux data. The absolute rating of the Pall membrane also affects the permeation rate. It should be noted that an average increase in flux of $7.5 \%$ is observed following preconditioning. This is possibly due to the removal of residual manufacturing impurities associated with the ceramic coating. 


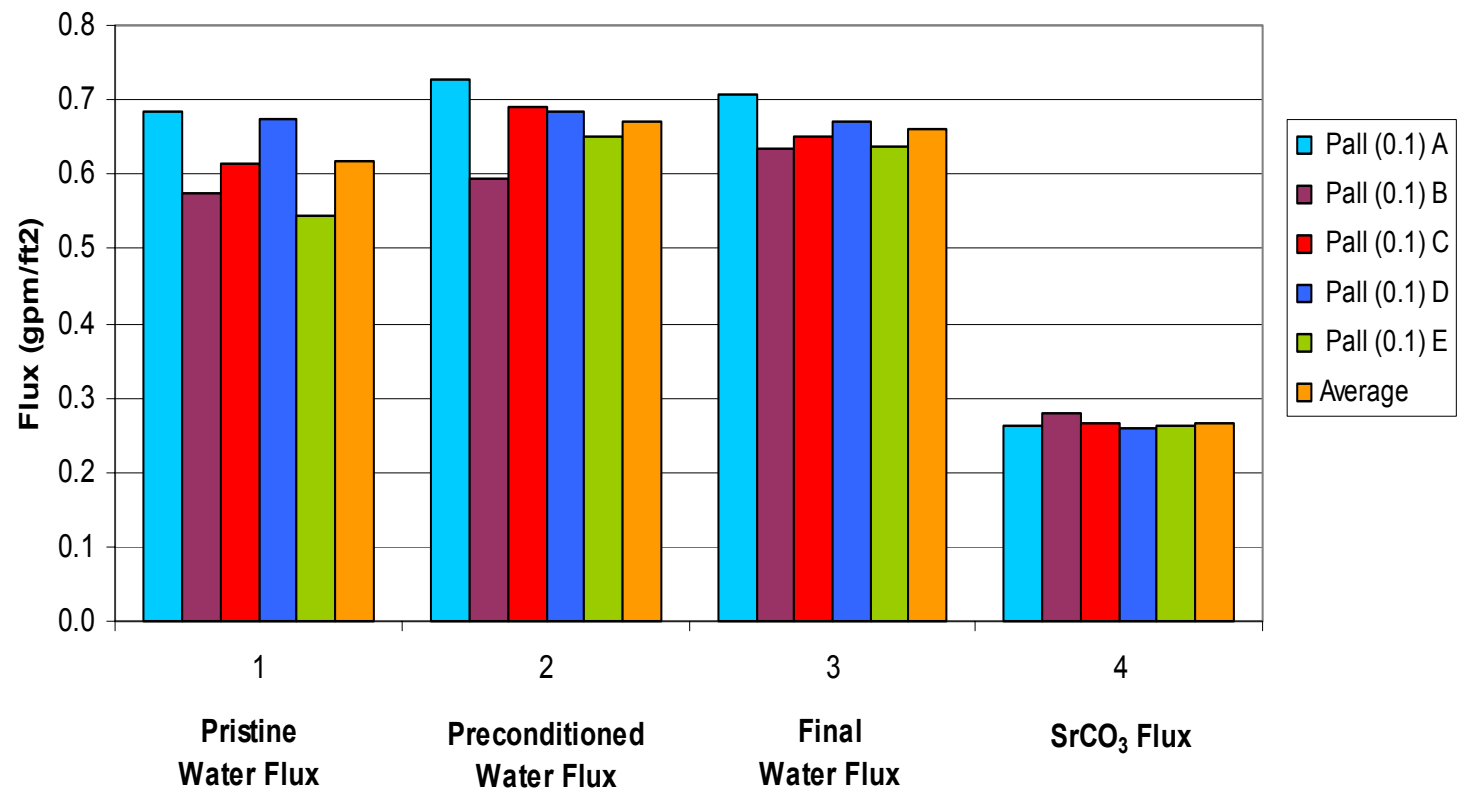

Figure 6. Fluxes for five Pall $0.1 \mu \mathrm{m}$ membranes are compared for the pristine, preconditioned, final water and $\mathrm{SrCO}_{3}$ tests.

Statistical analysis of variance techniques (ANOVA) applied to the complete set of water flux data for these membranes indicates no statistical differences are associated with the five Pall $0.1 \mu \mathrm{m}$ modules: all membranes are the same among respective pore sizes and none of them can be rejected on statistical grounds. In general, ANOVA analysis indicates that any of the five membrane modules could be chosen for testing with the SRS simulated wastes.

\subsubsection{Pall $0.8 \mu \mathrm{m}$}

Fluxes for five Pall $0.8 \mu \mathrm{m}$ membranes are shown in Figure 7. Comparisons are shown for the (asreceived) pristine water flux, water flux following the preconditioning sequence, final water flux (following $\mathrm{SrCO}_{3}$ and nitric acid rinse) and fluxes obtained from the $5.0 \mathrm{wt} \% \mathrm{SrCO}_{3}$ solution. Also shown is the average flux for the respective tests. The water fluxes through the membranes were quite inconsistent for all of the water flux data, and membrane $\mathrm{C}$ was consistently low and decreased further with each water flux test. The variability between the different membranes was statistically different based on ANOVA analysis, which indicated sample $\mathrm{C}$ was consistently low. All other modules were statistically the same when module $\mathrm{C}$ was removed from the ANOVA method. It is unknown why membrane $\mathrm{C}$ displayed such low fluxes. ANOVA analysis indicates that any of the four membrane modules (membrane $\mathrm{C}$ removed from testing) could be chosen for testing with the SRS simulated wastes. 


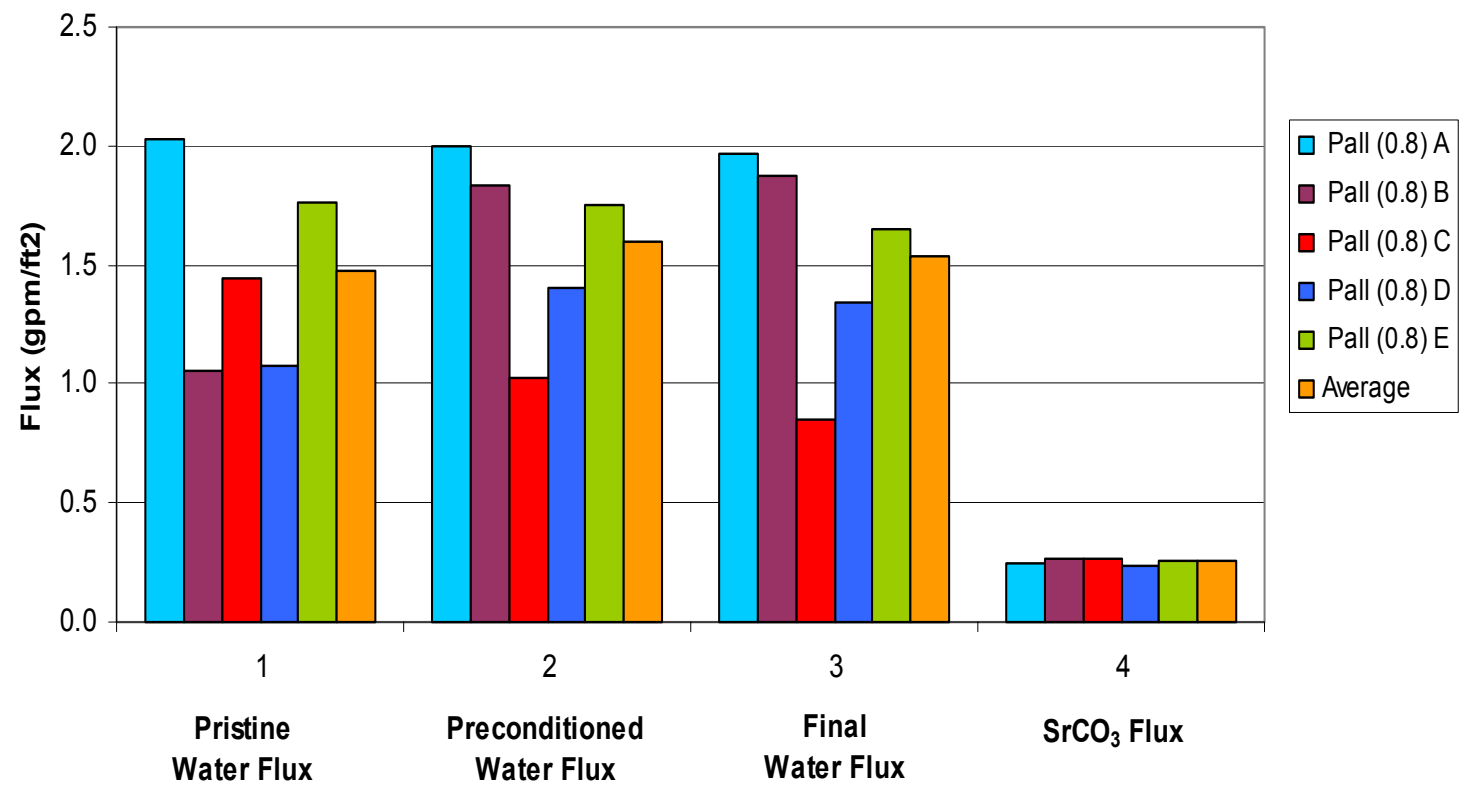

Figure 7. Fluxes for five Pall $0.8 \mu \mathrm{m}$ membranes are compared for the pristine, preconditioned, final water and $\mathrm{SrCO}_{3}$ tests.

\subsubsection{GKN $0.1 \mu \mathrm{m}$}

Fluxes for the five GKN $0.1 \mu \mathrm{m}$ membranes are shown in Figure 8. Comparisons are shown for the (as-received) pristine water flux, water flux following the preconditioning sequence, final water flux (following $\mathrm{SrCO}_{3}$ and nitric acid rinse) and fluxes obtained from the $5.0 \mathrm{wt} \% \mathrm{SrCO}_{3}$ solution. Also shown is the average flux for the respective tests. The data indicate that the water permeation rates through the GKN $0.1 \mu \mathrm{m}$ membranes were relatively high. It is important to note that for the GKN membranes, the high water flux, particularly at the higher TMP, results in a large amount of experimental error associated with the water flux measurement.

Statistical analysis of variance techniques (ANOVA) applied to the complete set of water flux data for these different membranes indicates no statistical differences are associated with these five GKN modules: all membranes are the same and none of them can be rejected on statistical grounds. In general, ANOVA analysis indicates that any of the five membrane modules could be chosen for testing with the SRS simulated wastes. 


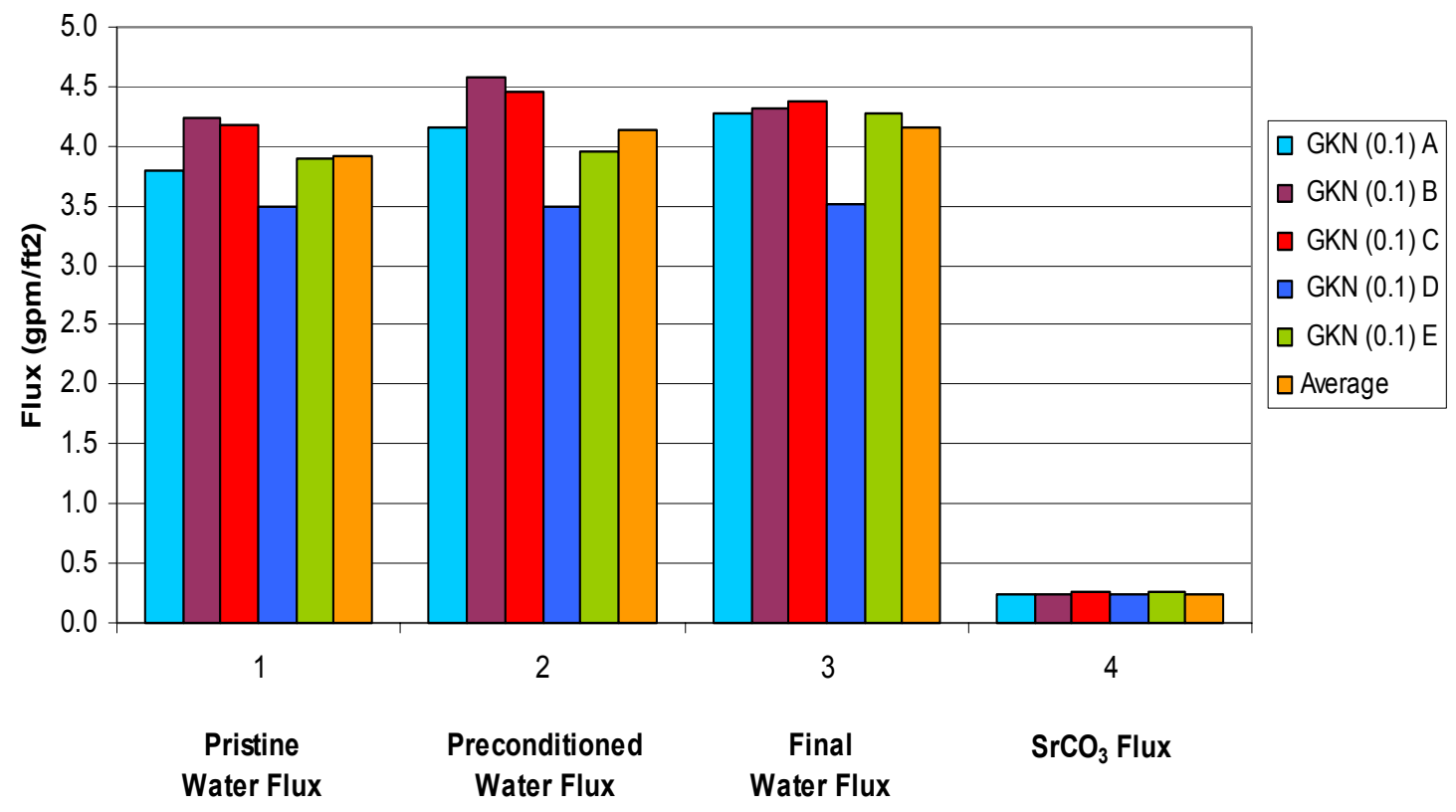

Figure 8. Fluxes for five GKN $0.1 \mu \mathrm{m}$ membranes are compared for the pristine, preconditioned, final water and $\mathrm{SrCO}_{3}$ tests.

Table 3 summarizes the average steady-state flux data for the different membrane modules and indicates which modules were selected for continued testing with the SRS simulated waste. Membranes for continued testing were selected by identifying the membrane that most closely resembled the average steady state flux of the five respective membranes. The variation is indicated by the associated standard deviations reported for each membrane set. The $\mathrm{H}_{2} \mathrm{O}$ and $\mathrm{SrCO}_{3}$ data are relative; the water data has units of flux/TMP or $\left(\mathrm{gpm} / \mathrm{ft}^{2}\right) / \mathrm{psig}$, while the $\mathrm{SrCO}_{3}$ flux data is in units of flux $/ \mathrm{AV}$ or $\left(\mathrm{gpm} / \mathrm{ft}^{2}\right) /(\mathrm{ft} / \mathrm{sec})$. In the case of the $\mathrm{SrCO}_{3}$ permeate measurements, where the experimental errors associated with the measurements are relatively low, the variability (based on the standard deviations) ranges from $3-12 \%$. In the case of the water flux measurements, the variations are substantially higher, ranging from $4-56 \%$. Note also that in the water flux measurements, the higher flux membranes (GKN $0.1 \mu \mathrm{m}$ and Mott $0.5 \mu \mathrm{m}$ membranes) have the greatest amount of variability, associated with the experimental uncertainties in measuring a large volume of permeate in a short amount of time. The data indicate that the water permeation rate through the Graver $(0.07 \mu \mathrm{m})$ and Pall $(0.1 \mu \mathrm{m})$ membranes are lowest among the membranes tested and have the lowest variability in the as-received membranes. Less variability is most likely due to consistency of the pore structure associated with the asymmetric ceramic coating.

Again, it must be emphasized that the purpose of this comparison is only to provide a measure of variability for each set of samples, and the comparison of the different membranes must be based on a representative feed stream for which they will be used; in this case the SRS simulated sludge + MST waste. 
Table 3. Summary of the average water and $\mathrm{SrCO}_{3}$ flux data for the different membranes.

\begin{tabular}{lccccc}
\hline \multicolumn{1}{c}{ Membrane } & $\begin{array}{c}\text { Test } \\
\text { Module } \\
\text { Selected }\end{array}$ & $\begin{array}{c}\text { Pristine Water } \\
(\mathrm{gpm} / \mathrm{ft} 2) / \mathrm{psid}\end{array}$ & $\begin{array}{c}\text { Preconditioned } \\
\text { Water } \\
(\mathrm{gpm} / \mathrm{ft} 2) / \mathrm{psid}\end{array}$ & $\begin{array}{c}\text { Final Water } \\
(\mathrm{gpm} / \mathrm{ft} 2) / \mathrm{psid}\end{array}$ & $\begin{array}{c}\mathrm{SrCO}_{3} \\
(\mathrm{gpm} / \mathrm{ft} 2) /(\mathrm{ft} / \mathrm{sec})\end{array}$ \\
\hline Graver $0.07 \mu \mathrm{m}$ & B & $0.022 \pm 0.006$ & $0.030 \pm 0.004$ & $0.024 \pm 0.003$ & $0.043 \pm 0.002$ \\
Mott $0.1 \mu \mathrm{m}$ & B & $0.102 \pm 0.011$ & $0.105 \pm 0.012$ & $0.105 \pm 0.019$ & $0.041 \pm 0.005$ \\
Mott $0.5 \mu \mathrm{m}$ & B & $0.395 \pm 0.046$ & $0.435 \pm 0.036$ & $0.567 \pm 0.187$ & $0.029 \pm 0.001$ \\
Pall $0.1 \mu \mathrm{m}$ & C & $0.021 \pm 0.003$ & $0.022 \pm 0.002$ & $0.023 \pm 0.001$ & $0.030 \pm 0.001$ \\
Pall $0.8 \mu \mathrm{m}$ & E & $0.053 \pm 0.016$ & $0.056 \pm 0.014$ & $0.054 \pm 0.017$ & $0.029 \pm 0.002$ \\
GKN $0.1 \mu \mathrm{m}$ & C & $0.768 \pm 0.433$ & $0.599 \pm 0.219$ & $0.595 \pm 0.177$ & $0.028 \pm 0.001$ \\
\hline
\end{tabular}

\subsection{Simulant Testing}

\subsection{1 $0.29 w t \%$}

The average steady-state flux for the five membranes using the $0.29 \mathrm{wt} \%$ SRS simulant is shown in Figure 9 . The average steady-state flux was calculated by averaging the final ( 0.5 hour $)$ steady state flux for each of the eleven parameters.

At $0.29 \mathrm{wt} \%$, the Graver $0.07 \mu \mathrm{m}$ and Pall $0.1 \mu \mathrm{m}$ membranes displayed the highest average fluxes at 0.061 and $0.060 \mathrm{gpm} / \mathrm{ft}^{2}$, respectively. Both membranes are of asymmetric construction with a ceramic coating on a stainless steel support. Interestingly, the GKN membrane, which is also of asymmetric construction, performed comparably to the asymmetric Pall $0.8 \mu \mathrm{m}$ with fluxes of 0.058 and 0.058 $\mathrm{gpm} / \mathrm{ft}^{2}$. The lowest average steady-state fluxes were obtained by the baseline Mott $0.1 \mu \mathrm{m}$ and Mott 0.5 $\mu \mathrm{m}$ membranes at 0.051 and $0.050 \mathrm{gpm} / \mathrm{ft}^{2}$. The average steady-state flux through the membranes decreased in the order:

Graver $0.07 \mu \mathrm{m}>$ Pall $0.1 \mu \mathrm{m}>$ Pall $0.8 \mu \mathrm{m}>$ GKN $0.1 \mu \mathrm{m}>$ Mott $0.1 \mu \mathrm{m}>$ Mott $0.5 \mu \mathrm{m}$

At the completion of the $0.29 \mathrm{wt} \%$ test, the simulated waste was drained from the CUF system and the system rinsed with DI water. Water rinses were performed approximately three times using 2 liters of water per rinse. This was typically performed with the permeate valve closed. This was followed by chemically cleaning the membranes using approximately 2 liters of $0.5 \mathrm{M}$ oxalic acid for 0.5 hours at an axial velocity of $9 \mathrm{ft} / \mathrm{sec}$ and a transmembrane pressure of $30 \mathrm{psig}$. Multiple chemical cleaning steps were often needed depending on the cleanability of the respective membrane. Once chemical cleaning was complete, acid solutions were drained from the system and a water flux was performed. Water fluxes were used to observe how closely the membrane had returned to near pristine levels in preparation for the subsequent $4.5 \mathrm{wt} \%$ test. All membranes tested displayed a decrease in water flux following the $0.29 \mathrm{wt} \%$ test. 


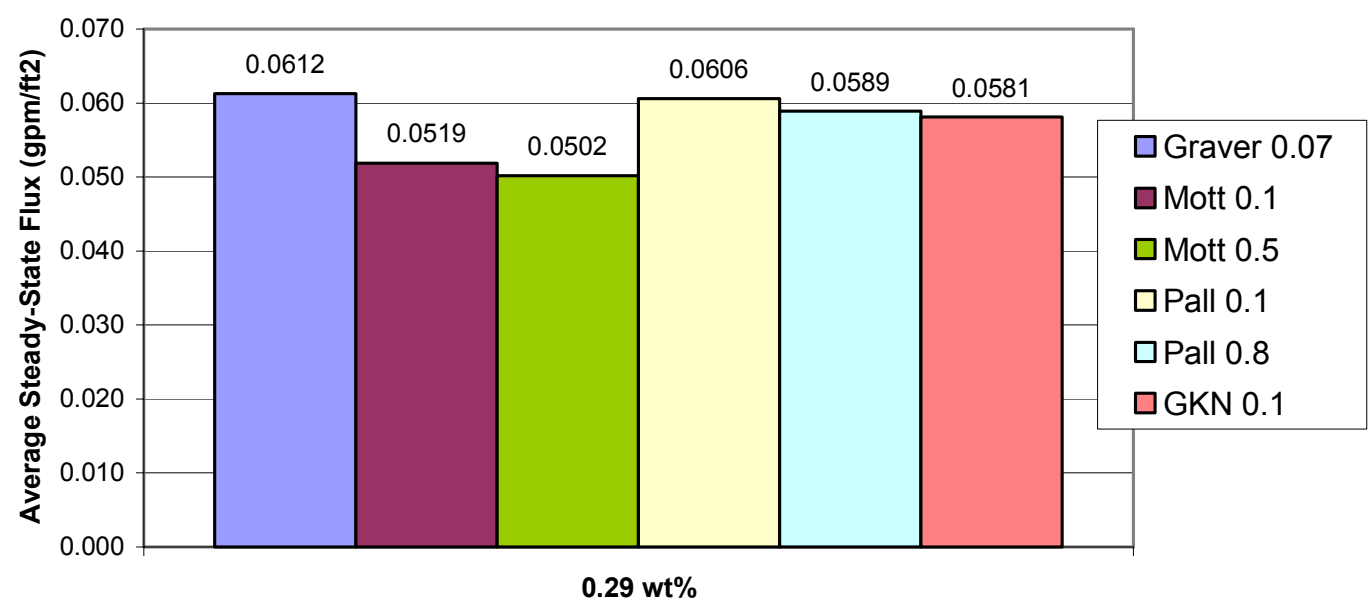

Figure 9. The average steady-state flux for the five membranes using the $0.29 \mathrm{wt} \% \mathrm{SRS}$ simulant.

\section{$3.2 .2 \quad 4.5 w t \%$}

The average steady-state flux for the five membranes tested using the $4.5 \mathrm{wt} \%$ SRS simulant is shown in Figure 10. The average steady-state flux was calculated by averaging the final ( 0.5 hour) steady state flux for each of the eleven parameters. It should be noted that an additional test at $4.5 \mathrm{wt} \%$ was completed for the Mott 0.5 and GKN 0.1 membranes. Initial simulant tests at $4.5 \mathrm{wt} \%$ displayed lower fluxes than expected with the Mott 0.5 and GKN 0.1 membranes. The initial and repeated final steadystate fluxes were combined and averaged and are shown in Figure 10.

At $4.5 \mathrm{wt} \%$, the Pall $0.1 \mu \mathrm{m}$ and Graver $0.07 \mu \mathrm{m}$ membranes display the highest average fluxes at 0.039 and $0.036 \mathrm{gpm} / \mathrm{ft}^{2}$, respectively. Interestingly, the Pall $0.8 \mu \mathrm{m}$ membrane, which displayed unusually low water fluxes prior to testing, performed comparably to the Graver membrane at 0.0366 $\mathrm{gpm} / \mathrm{ft}^{2}$. The lowest average steady state fluxes at $0.035,0.034$ and $0.032 \mathrm{gpm} / \mathrm{ft}^{2}$ were obtained by the GKN, Mott $0.5 \mu \mathrm{m}$ and the SRS baseline Mott $0.1 \mu \mathrm{m}$, respectively. The average steady-state flux through the membranes decreased in the order:

$$
\text { Pall } 0.1 \mu \mathrm{m}>\text { Graver } 0.07 \mu \mathrm{m}>\text { Pall } 0.8 \mu \mathrm{m}>\text { GKN } 0.1 \mu \mathrm{m}>\text { Mott } 0.5 \mu \mathrm{m}>\text { Mott } 0.1 \mu \mathrm{m}
$$

At the completion of the $4.5 \mathrm{wt} \%$ test, a similar chemical cleaning procedure, as performed in the $0.29 \mathrm{wt} \%$ test was performed. However, due to the increased solids loading, additional water and chemical cleaning steps were required to remove solids. 


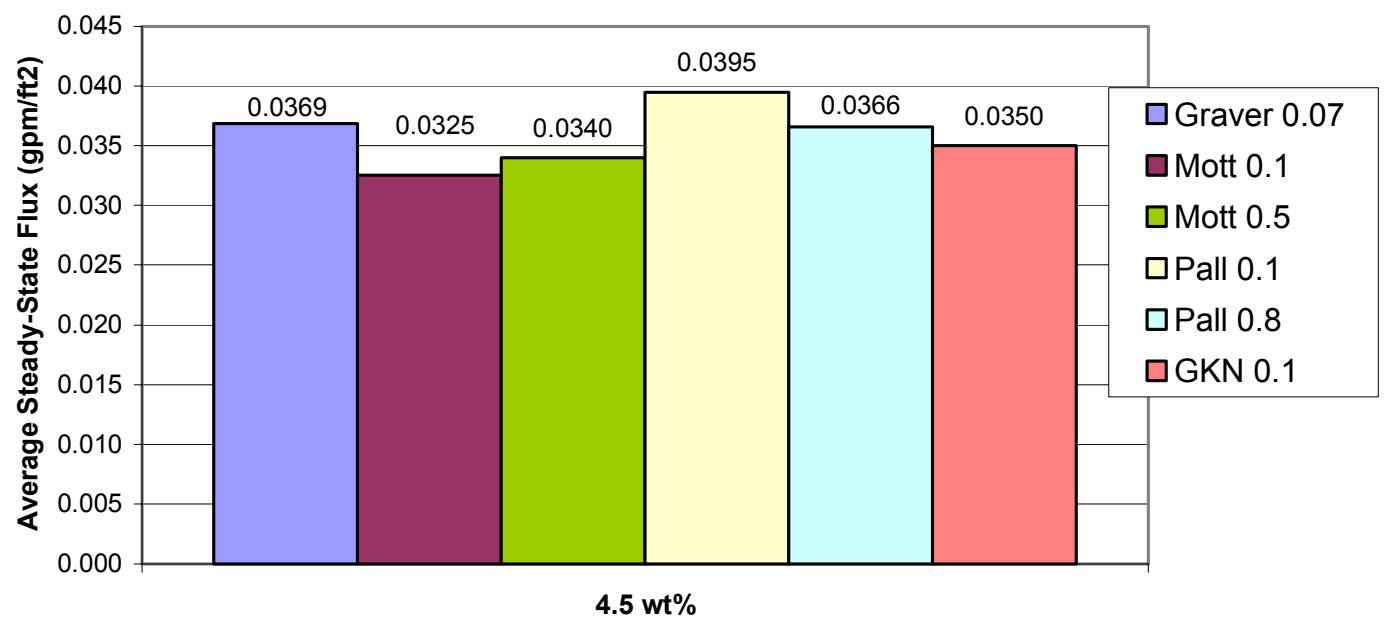

Figure 10. The average steady-state flux for the five membranes using the $4.5 \mathrm{wt} \%$ SRS simulant.

\subsubsection{Statistical Analysis}

The authors performed statistical analyses on the simulant flux data to determine which of the operating parameters (filter media, insoluble solids concentration, transmembrane pressure, and axial velocity) had a significant effect on filter flux. The analyses were performed (with JMP software) by developing a model to calculate the filter flux (in $\mathrm{L} / \mathrm{m}^{2} \mathrm{hr}$ ) as a function of filter media, insoluble solids (wt $\%)$, transmembrane pressure (bar), and axial velocity $(\mathrm{m} / \mathrm{s})$.

The statistical analysis of all the filter media is shown in Table 1 of Appendix B. The analysis shows the insoluble solids concentration and axial velocity have the strongest effect on filter flux, and that the effects are statistically significant. The analysis also shows the transmembrane pressure and filter media have statistically significant effects on filter flux, but the effects are less than the effects of insoluble solids concentration and axial velocity. The $0.1 \mu \mathrm{m}$ Pall and $0.07 \mu \mathrm{m}$ Graver media produced the highest mean flux.

Additional statistical analysis was completed as a basis of comparison between the various alternative filter media. The following comparisons were evaluated:

- $\quad$ Pall $0.1 \mu \mathrm{m}$ and Mott $0.1 \mu \mathrm{m}$

- $\quad$ Graver $0.07 \mu \mathrm{m}$ and Mott $0.1 \mu \mathrm{m}$

- $\quad$ Graver $0.07 \mu \mathrm{m}$ and Pall $0.1 \mu \mathrm{m}$

- $\quad$ Mott $0.1 \mu \mathrm{m}$ and Mott $0.5 \mu \mathrm{m}$

The statistical analysis of the Pall $0.1 \mu \mathrm{m}$ and Mott $0.1 \mu \mathrm{m}$ filter media are shown in Table 2 of Appendix B. The analysis shows the insoluble solids concentration and axial velocity have the strongest effect on filter flux, and that the effects are statistically significant. The analysis shows the transmembrane pressure does nt have a statistically significant effect on filter flux. Filter media has a 
statistically significant effect on filter flux, but the effect is less than the effect of insoluble solids concentration and axial velocity.

The statistical analysis of the Graver $0.07 \mu \mathrm{m}$ and Mott $0.1 \mu \mathrm{m}$ filter media are shown in Table 3 of Appendix B. The analysis shows the insoluble solids concentration and axial velocity have the strongest effect on filter flux, and that the effects are statistically significant. The analysis shows the transmembrane pressure does not have a statistically significant effect on filter flux. Filter media has a statistically significant effect on filter flux, but the effect is less than the effect of insoluble solids concentration and axial velocity.

The statistical analysis of the Graver $0.07 \mu \mathrm{m}$ and Pall $0.1 \mu \mathrm{m}$ filter media are shown in Table 4 of Appendix B. The analysis shows the insoluble solids concentration and axial velocity have the strongest effect on filter flux, and that the effects are statistically significant. The analysis shows the transmembrane pressure does not have a statistically significant effect on filter flux. Filter media does not have a statistically significant effect on filter flux. Therefore, filter flux with the Pall $0.1 \mu \mathrm{m}$ and the Graver $0.07 \mu \mathrm{m}$ filters is statistically the same.

The statistical analysis of the Mott $0.5 \mu \mathrm{m}$ and Mott $0.1 \mu \mathrm{m}$ filter media are shown in Table 5 of Appendix B. The analysis shows the insoluble solids concentration and axial velocity have the strongest effect on filter flux, and that the effects are statistically significant. The analysis shows the transmembrane pressure does not have a statistically significant effect on filter flux. Filter media does not have a statistically significant effect on filter flux. Therefore, filter flux with the Mott $0.1 \mu \mathrm{m}$ and the Mott $0.5 \mu \mathrm{m}$ filters is statistically the same.

\subsection{SRNL Comparison}

After close examination of INEEL simulant flux data performed at $4.5 \mathrm{wt} \%$, it was speculated that a discrepancy between the INEEL and prior Savannah River National Laboratory (SRNL) data existed. Personnel from the Savannah River National Laboratory and the University of South Carolina (USC) had previously conducted engineering-scale filtration tests using the Filtration Research Engineering Demonstration (FRED) facility and the Mott $0.1 \mu \mathrm{m}$ membrane. ${ }^{(12)}$

Figure 11 displays flux as a function of axial velocity for the Mott $0.1 \mu \mathrm{m}$ membrane at $4.5 \mathrm{wt} \%$ for tests performed at the INEEL and SRNL (FRED facility). Fluxes obtained at SRNL were approximately $20-50 \%$ higher than those obtained in the INEEL study. Similar tests conditions were utilized between the two tests, however, a few experimental differences were observed, which could account for the difference in flux. Table 4 displays the experimental differences for simulant tests performed with the Mott $0.1 \mu \mathrm{m}$ at the INEEL and SRNL. In addition, the potential impacts in respect to the experimental differences are also shown. 


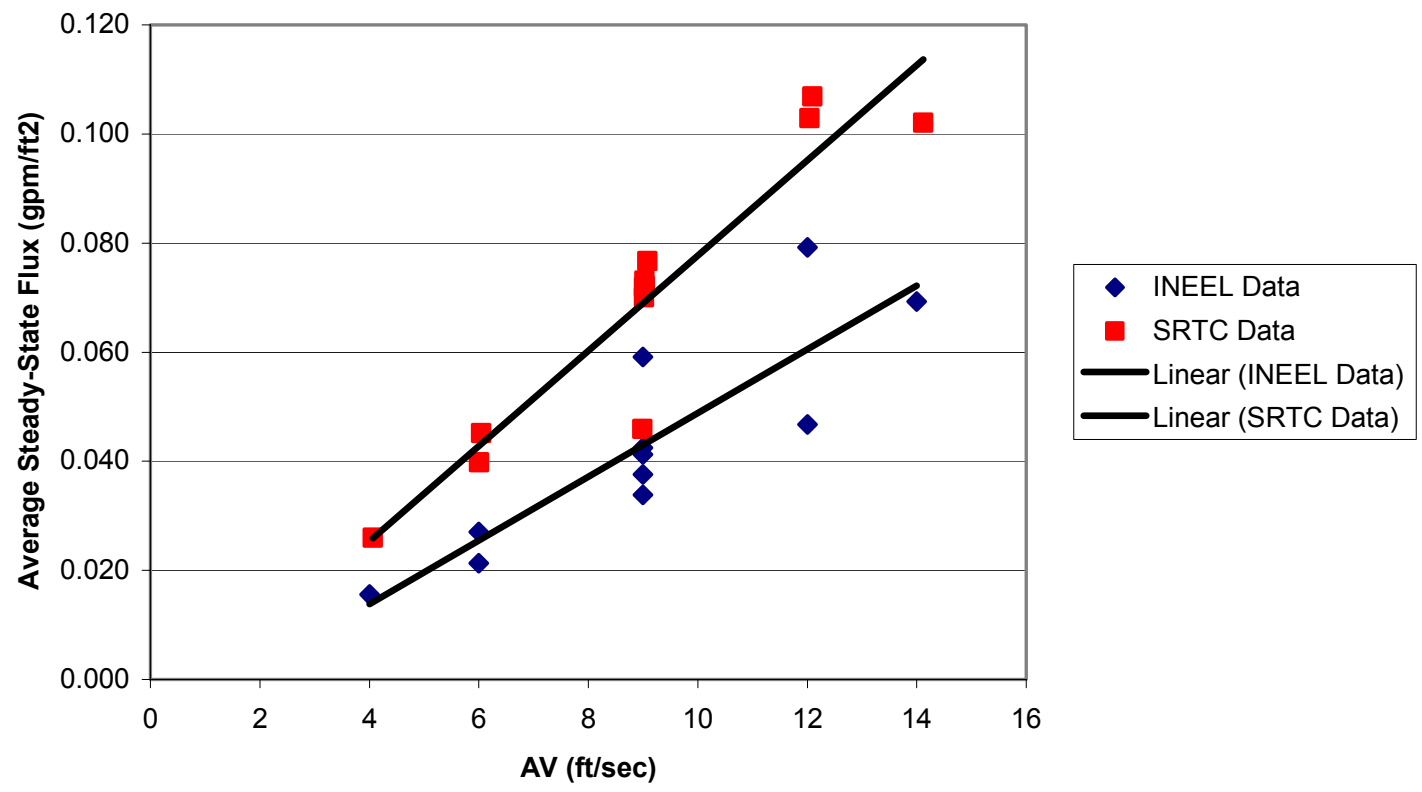

Figure 11. Flux as a function of axial velocity for the Mott $0.1 \mu \mathrm{m}$ membrane at $4.5 \mathrm{wt} \%$ for tests performed at the INEEL and SRNL (FRED Facility).

Table 4. Experimental differences for simulant tests performed with the Mott $0.1 \mu \mathrm{m}$ at the INEEL and SRNL (FRED facility).

\begin{tabular}{|c|c|c|c|}
\hline & INEEL & (SRNL) FRED & Impacts \\
\hline $\begin{array}{l}\text { Particle Size } \\
\text { Distribution in Feed }\end{array}$ & $\begin{array}{l}\text { Particle size } 4.32-4.39 \mu \mathrm{m} \\
\text { based on Microtrac analysis } \\
\text { measured at SRTC }\end{array}$ & $\begin{array}{l}\text { Particle size of } 3.56- \\
4.09 \mu \mathrm{m} \text { based on } \\
\text { Microtrac analysis } \\
\text { measured at SRTC }\end{array}$ & $\begin{array}{l}\text { Smaller particles foul } \\
\text { membrane or produce } \\
\text { tighter cake, lower flux }\end{array}$ \\
\hline $\begin{array}{l}\text { Membrane } \\
\text { Diameter }\end{array}$ & $3 / 8$ & $5 / 8$ & $\begin{array}{l}\text { Smaller membrane would } \\
\text { produce higher wall shear } \\
\text { at same AV increasing flux }\end{array}$ \\
\hline Number of Tubes & (1 tube, $2 \mathrm{ft}$ long) & (7 tubes, 10 feet long) & $\begin{array}{l}\text { Shorter length with less } \\
\text { tubes = higher fraction is at } \\
\text { the entrance region, which } \\
\text { has higher mass transfer } \\
\text { coefficient, increasing flux } \\
\text { - }\end{array}$ \\
\hline Temperature & $25^{\circ} \mathrm{C}$ & $35^{\circ} \mathrm{C}$ & $\begin{array}{l}\text { Higher temperature yields } \\
\text { higher flux due to change in } \\
\text { viscosity }\end{array}$ \\
\hline Backpulse Pressure & 40 psig & 100 psig & $\begin{array}{l}\text { Higher backpulse pressure } \\
\text { produces better particle } \\
\text { removal efficiency }\end{array}$ \\
\hline $\begin{array}{l}\text { Insoluble Solids } \\
(\mathrm{wt} \%)\end{array}$ & $10.8 \mathrm{wt} \%$ feed stock & $\sim 7.0 \mathrm{wt} \%$ feed stock & $\begin{array}{l}\text { Higher solids loading create } \\
\text { added resistance and } \\
\text { decreased flux }\end{array}$ \\
\hline
\end{tabular}


As a result of the differences described in Table 4, we performed additional testing to provide a direct comparison with tests performed at SRNL. Additional testing was completed on the Graver $0.07 \mu \mathrm{m}$, Mott $0.1 \mu \mathrm{m}$ and Pall $0.1 \mu \mathrm{m}$. These membranes displayed the highest average steady-state flux during original testing with SRS simulated waste at solids loadings of 0.29 and $4.5 \mathrm{wt} \%$.

As a basis of comparison, two test conditions were changed: operating temperature and backpulse pressure. Operating temperatures were increased from $25^{\circ} \mathrm{C}$ to $35^{\circ} \mathrm{C}$ and backpulse pressures were increased from 40 psig to 90 psig. The 90 psig backpulse was selected, because the Pall $0.1 \mu \mathrm{m}$ filter has a maximum operating pressure of 90 psig. Accordingly, backpulses were performed at $90 \mathrm{psig}$ for all membranes. Flux was measured in accord with the matrix conditions indicated in Table 2 (vide supra). However, an additional "preflux" parameter (repeat of condition \#1) was added to the test matrix to decrease the high variation in initial-flux measurements. Additional tests were performed with SRS simulated waste at solids loadings of 0.06 and $4.5 \mathrm{wt} \%$. Figures 12 and 13 indicate the average steadystate flux for the Mott $0.1 \mu \mathrm{m}$ (FRED pilot facility), Mott $0.1 \mu \mathrm{m}$ (INEEL), Graver $0.07 \mu \mathrm{m}$ and Pall $0.1 \mu \mathrm{m}$ membranes using simulated SRS waste at 0.06 and $4.5 \mathrm{wt} \%$ at $35^{\circ} \mathrm{C}$.

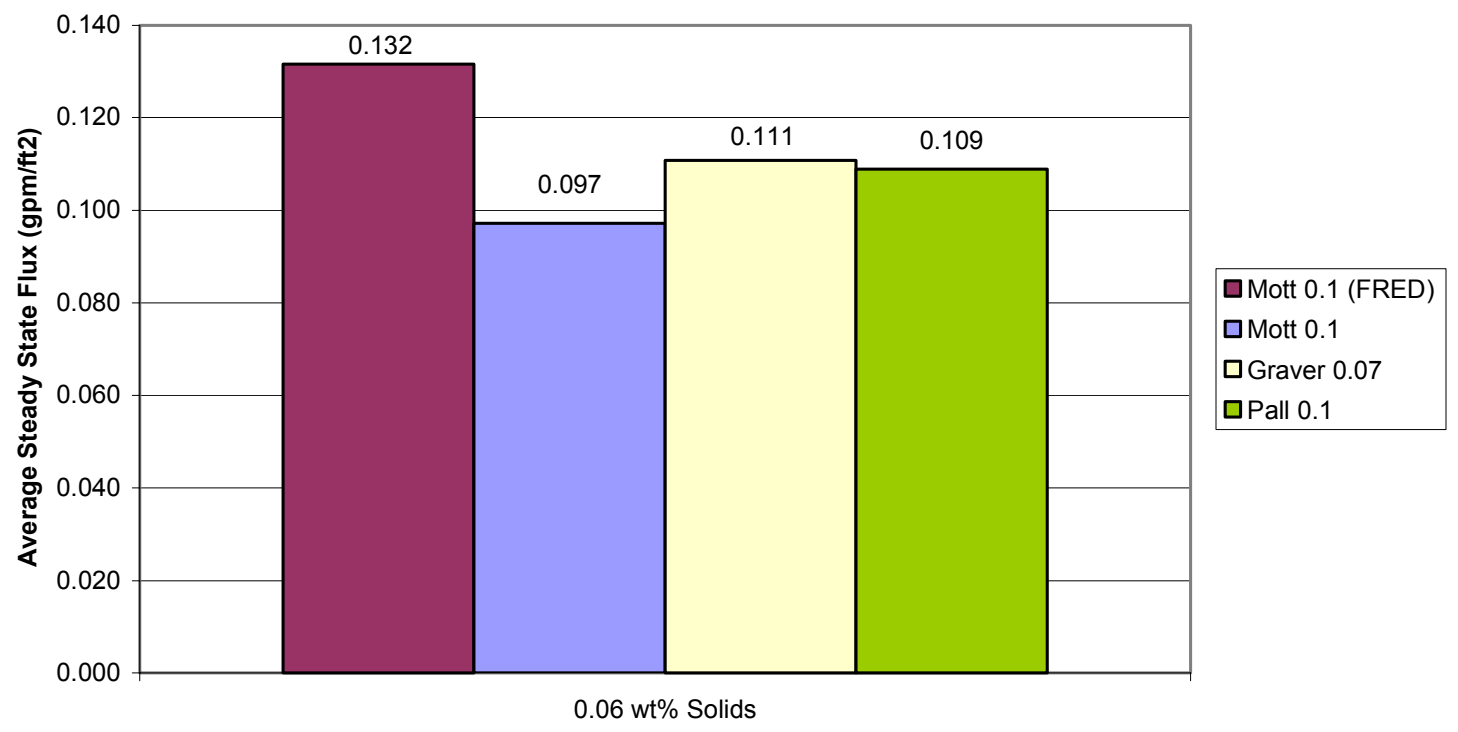

Figure 12. Average steady-state for the Mott $0.1 \mu \mathrm{m}$ (FRED facility), Mott $0.1 \mu \mathrm{m}$ (INEEL), Graver 0.07 $\mu \mathrm{m}$ and Pall $0.1 \mu \mathrm{m}$ membranes using the SRS simulant at $0.06 \mathrm{wt} \%$ at $35^{\circ} \mathrm{C}$. 


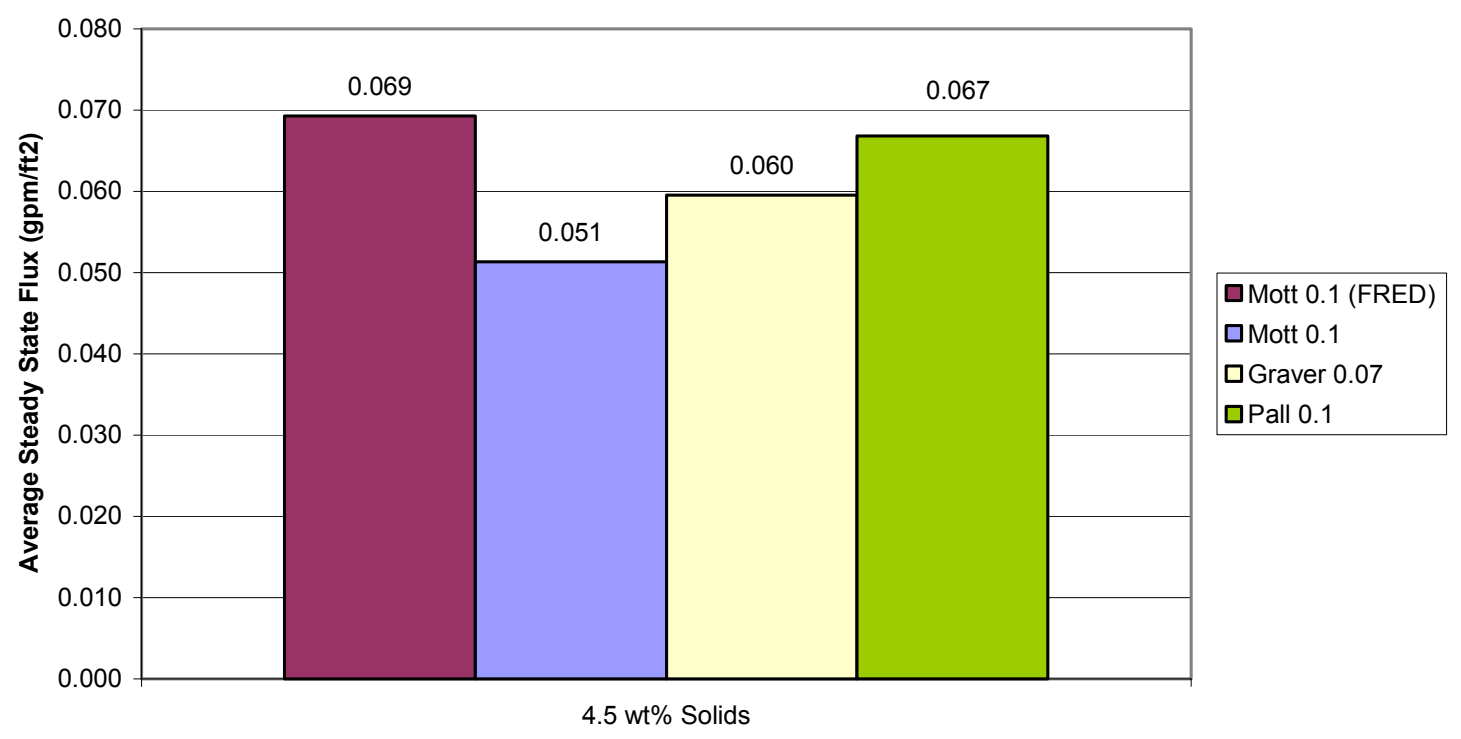

Figure 13. Average steady-state flux for the Mott $0.1 \mu \mathrm{m}$ (FRED Facility), Mott $0.1 \mu \mathrm{m}$ (INEEL), Graver $0.07 \mu \mathrm{m}$ and Pall $0.1 \mu \mathrm{m}$ membranes using the SRS simulant at $4.5 \mathrm{wt} \%$ at $35^{\circ} \mathrm{C}$.

At 0.06 and $4.5 \mathrm{wt} \%$, the Graver $0.07 \mu \mathrm{m}$ and Pall $0.1 \mu \mathrm{m}$ membranes displayed the highest average steady-state fluxes. Interestingly, the order of performance remained the same when compared to previous testing. The Graver membrane displayed the highest average steady-state flux at the low solids loading and the Pall membrane displayed the highest average steady-state flux at the high solids loading. In general, fluxes were 11-31\% higher for the Graver $0.07 \mu \mathrm{m}$ and Pall $0.1 \mu \mathrm{m}$ membranes when compared to the baseline Mott $0.1 \mu \mathrm{m}$ membrane.

Statistical analysis of the data collected at $35{ }^{\circ} \mathrm{C}$ is shown in Table 6 of Appendix B. The analysis indicates the insoluble solids concentration and axial velocity have the strongest effect on filter flux, and that the effects are statistically significant. The analysis also shows the transmembrane pressure and filter media have statistically significant effects on filter flux, but the effects are less than the effects of insoluble solids concentration and axial velocity. This analysis is consistent with the results for the testing at $25^{\circ} \mathrm{C}$.

Although tests were performed in replication of tests performed at SRNL (FRED facility), flux values obtained at the INEEL were still approximately 25 percent lower. As an after thought, the discrepancies were discovered to be a difference in simulant test solutions, specifically solids loading and particle size diameter. The INEEL received simulated sludge and MST solids at a solids loading of approximately $7.25 \mathrm{wt} \%$, as determined by SRNL. Following simulant testing at the INEEL, six samples of the $4.5 \mathrm{wt} \%$ test solutions were back-calculated to determine the solids loading of the actual asreceived simulated sludge and MST solids. A solids loading of $10.8 \mathrm{wt} \%$ was determined. The solids loadings of test solutions utilized at the INEEL were approximately $33 \%$ higher than those tested at the FRED facility. Thus, the calculated solids loadings for the tests solutions were $0.09,0.43$ and $6.7 \mathrm{wt} \%$, respectively. To substantiate this, Mott $0.1 \mu \mathrm{m}$ flux data obtained at the FRED facility was interpolated using a solids loading of $6.7 \mathrm{wt} \%$. The flux data was calculated at $0.051 \mathrm{gpm} / \mathrm{ft}^{2}$. Fluxes obtained at the INEEL were also $0.051 \mathrm{gpm} / \mathrm{ft}^{2}$. Moreover, interpolating the lower concentration data at $0.43 \mathrm{wt} \%$ (based on the natural $\log$ of the concentration), a flux of $0.096 \mathrm{gpm} / \mathrm{ft}^{2}$ was calculated for the FRED facility. 
Fluxes obtained at the INEEL were $0.097 \mathrm{gpm} / \mathrm{ft}^{2}$. Consequently, the differences in the INEEL and SRNL data are largely attributed to the differences in percent solids loading between the feed solutions.

In addition to solids loading analysis, the authors performed particle size analyses with a Lasentec probe and with a Microtrac S3000 particle size analyzer. Personnel collected particle measurements with a Focused Beam Reflectance Measurement (FBRM) probe (Lasentec $\left.{ }^{\circledR}\right)$. The probe works in the following manner. Personnel installed the probe in the feed tank. The laser beam projects through the window of the FBRM probe and focuses just outside the window surface. This focused beam follows a path around the circumference of the probe window. As particles pass by the window surface, the focused beam will intersect the edge of a particle. The particle will backscatter laser light. The particle will continue to backscatter the light until the focused beam reaches the opposite edge of the particle. The instrument collects the backscattered light and converts it into an electronic signal. The FBRM isolates the time of backscatter from one edge of an individual particle to its opposite edge. The software records the product of the time multiplied by the scan speed as a chord length. A chord length is a straight line between any two points on the edge of a particle or particle structure (agglomerate). FBRM typically measures tens of thousands of chords per second, resulting in a robust number-by-chord-length distribution. The chordlength distribution provides a means of tracking changes in both particle dimension and particle population. The calculations do not assume a particle shape. The chord-length distribution is essentially unique for any given particle size and shape distribution. Assuming the average particle shape remains constant over millions of particles, changes to the chord-length distribution reflect solely a function of the change in particle dimension and particle number. Slurry samples from the current test and the pilot-scale test were analyzed with the FBRM. Personnel obtained $200 \mathrm{ml}$ slurry samples and placed them in a beaker. They agitated the slurry with an impeller and placed the FBRM probe into the slurry. Figure 14 shows the particle distribution measured. The slurry samples in the current test had a smaller media particle size than the samples in the pilot-scale test. The difference was $25 \%$ at the lower concentration and $17 \%$ at the higher concentration. Many filtration models predict filter flux to be proportional to particle size squared ${ }^{(16,17)}$, this difference in particle size would correspond to a difference in filter flux of $35-55 \%$.

Following the FBRM measures, personnel submitted the samples to the SRNL Analytical Development Section for particle size analysis with a Microtrac S3000. The Microtrac instrument can measure smaller particle sizes than the FBRM (as small as $0.026 \mu \mathrm{m}$ ). The results are displayed in Figure 15. The low solids slurry used in the pilot-scale tests at FRED has a smaller median particle size than the low solids slurry used in the current tests. Moreover, when referring to the low particle size of the graph, the samples from the current test have more fine particles $(<1$ micron) than the samples from the pilot-scale test. The fine particles could become trapped in the filter pores and decrease the filter permeability. In addition, the slurry from the current test performed at the INEEL has a wider particle size distribution. A wider distribution allows the particles to pack more tightly and decreases the filter cake permeability. 


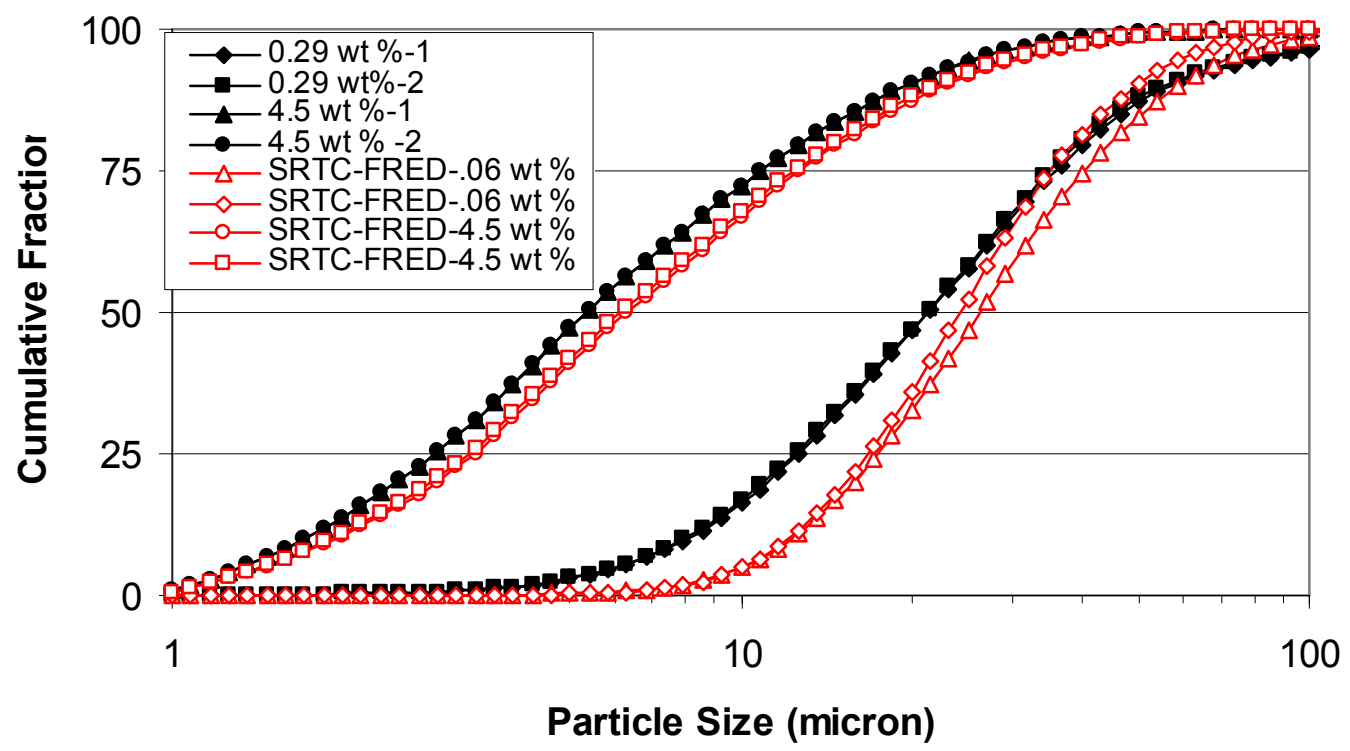

Figure 14. Focused Beam Reflectance Measurement (FBRM) of slurry samples.

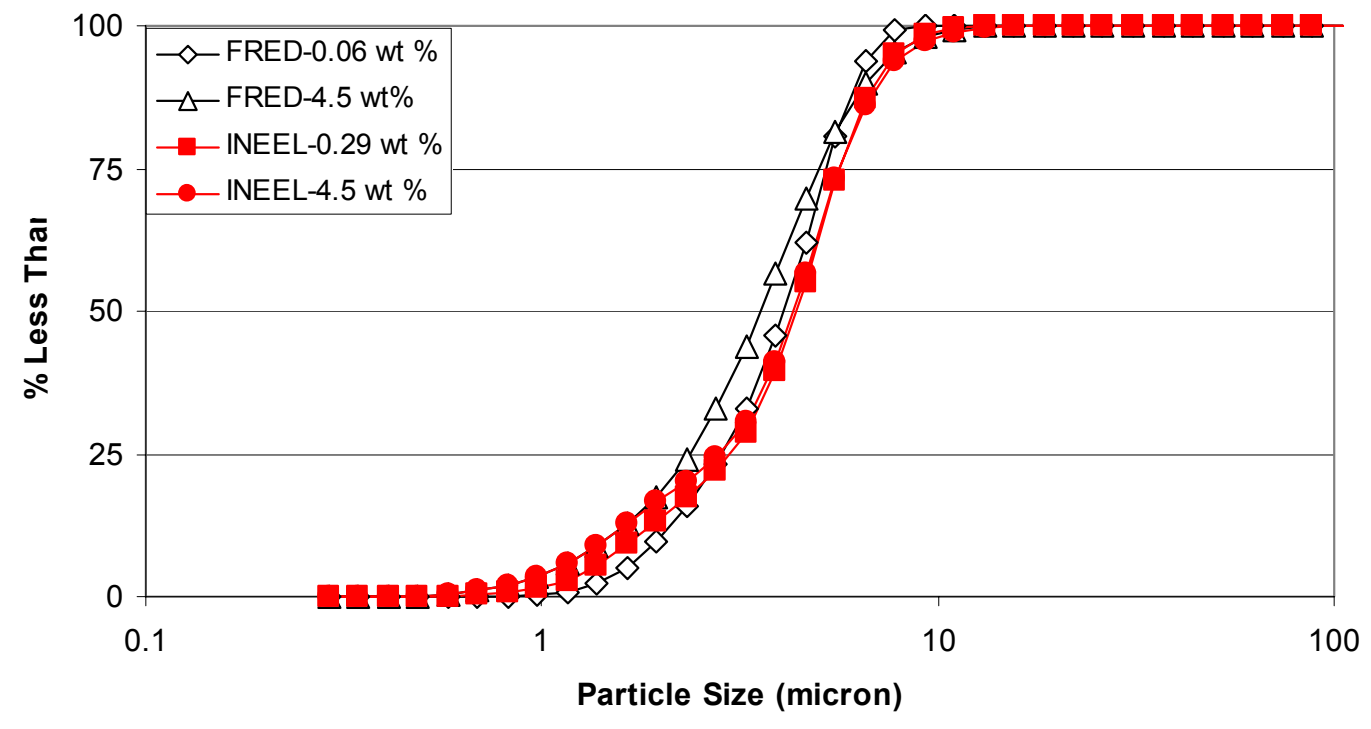

Figure 15. Microtrac S3000 Particle Size Measurements.

It is unknown why or how the differences in solids loading and/or particle size diameter occurred between the two tests. However, it was postulated that the finer particles observed in the current tests were the result of shear effects within the CUF apparatus. To evaluate this theory, particle size measurements were performed on samples of the stock SRS simulant (as supplied by SRNL and not tested at the INEEL) and simulant solutions following testing. Samples of test solutions were obtained prior to and after testing to validate test solutions and identify potential de-agglomeration of solids due to shear effects experienced during testing. 
Particle size analysis was performed using the Microtrac-FRA-9200 particle size analyzer. The Microtrac-FRA-9200 (Leeds \& Northrup) particle size analyzer consists of a small volume sample recirculator, measurement module and computer. The Microtrac FRA-9200 utilizes the phenomenon of low-angle forward scattered light from a laser beam projected through a stream of particles. The amount and direction of light scattered by the particles is measured by an optical detector array and then analyzed by the computer, which calculates the size distribution of the particles in the sample. The MircortracFRA9200 provides particle size analysis in the range of 0.12 to 704 microns.

Figures 16 and 17 display the particle size data collected for the as-received SRS solids and slurry samples obtained at the completion of the $0.29 \mathrm{wt} \%$ and $4.5 \mathrm{wt} \%$ tests for each membrane. The median particle size for the as-received sample was $4.11 \mu \mathrm{m}$. The average median particle size for the slurry samples obtained at the completion of testing at 0.29 and $4.5 \mathrm{wt} \%$ was $4.14 \pm 0.05$ and $4.16 \pm 0.06$, respectively. Slurry samples were obtained prior to testing for each membrane, but are not shown. Slurry samples obtained prior to testing were nearly identical to the as-received SRS solids. It is postulated that de-agglomeration due to shear did not occur, as evidenced by the static PSD analysis prior to and following testing.

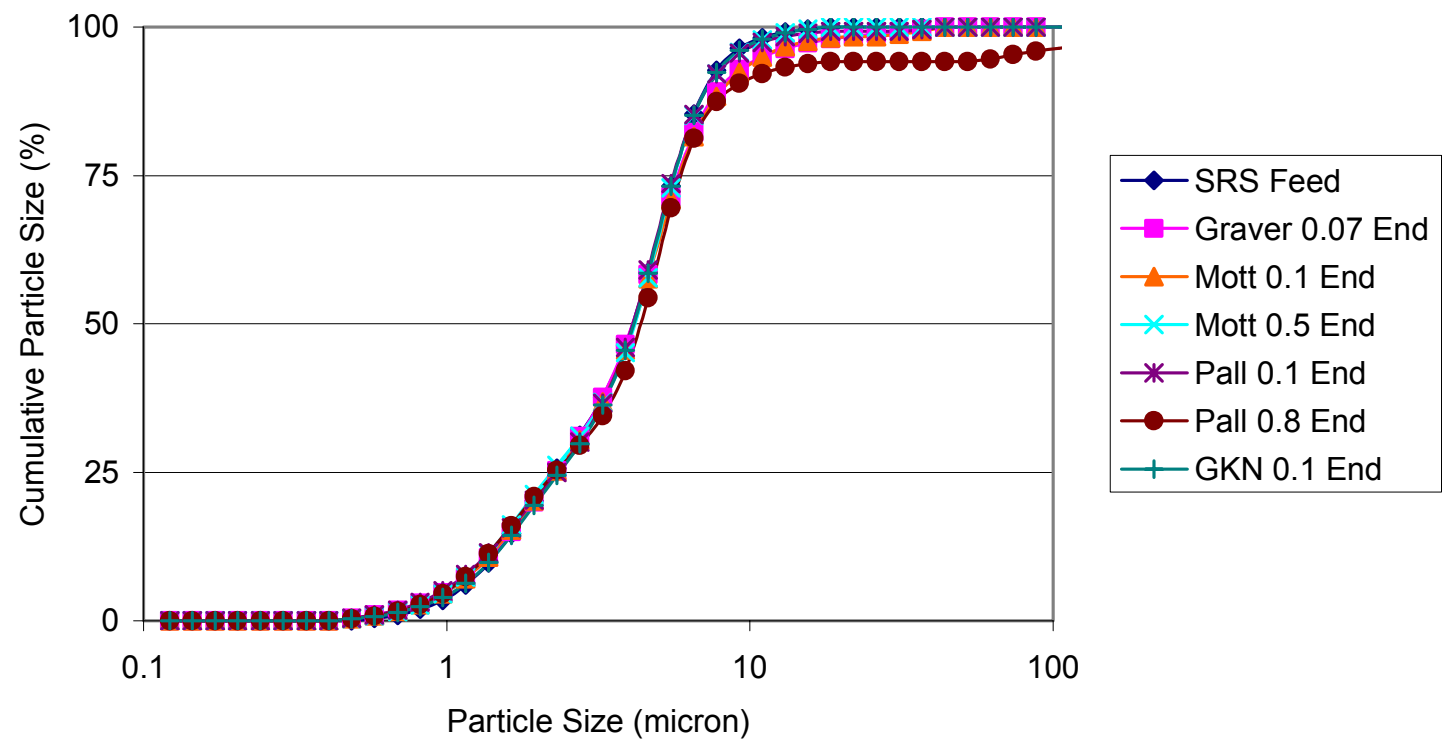

Figure 16. Particle size data collected for the as-received SRS solids and slurry samples obtained at the completion of the $0.29 \mathrm{wt} \%$ simulant tests for each membrane. 


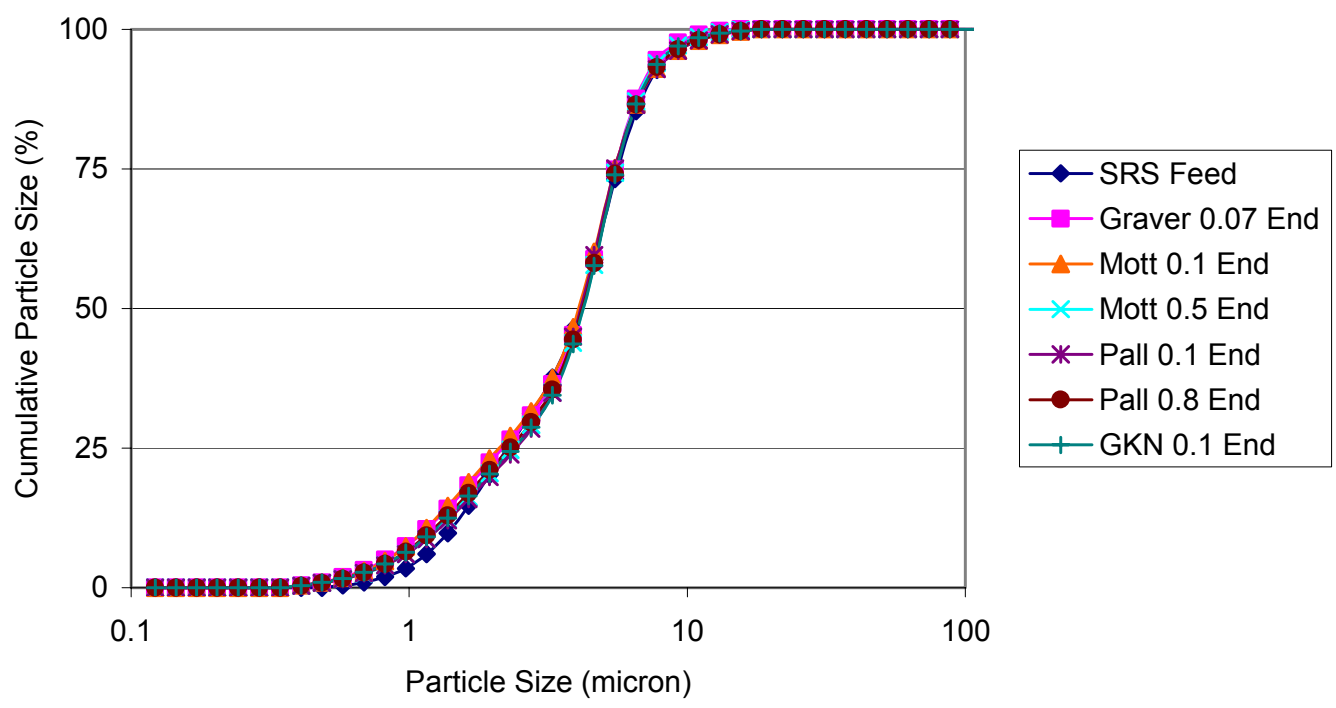

Figure 17. Particle size data collected for the as-received SRS solids and slurry samples obtained at the completion for the $4.5 \mathrm{wt} \%$ simulant tests for each membrane.

\subsection{SEM Analysis}

Analysis using the Scanning Electron Microscope (SEM) was completed on the five membrane samples following simulant testing. The purpose of the additional analysis was to qualitatively observe the membranes under high magnification in order to identify potential fouling phenomena within the pore structure of the membranes. At the completion of the repeated $4.5 \mathrm{wt} \%$ simulant testing, membranes were not chemically cleaned with $0.5 \mathrm{M}$ oxalic acid. Instead, membranes were water rinsed (in-situ). This method allowed for the removal of the bulk solids or cake from the system, but left particulate potentially fouled within the pores intact.

Membranes were prepared by first removing the active membrane from the respective permeate housings. Cutting a 6-inch section from the center of the 24-inch long membrane followed this. The 6inch sections were then cut in half along the length of the membrane. To finish, the partial 6-inch section of membrane was scarred and fractured into small 0.5 -inch pieces. The final 0.5 -inch pieces were then used for SEM analysis.

Figure 18 displays a SEM micrograph of the Graver $0.07 \mu \mathrm{m}$ membrane at $1000 \mathrm{X}$ magnification. The SEM micrograph is taken at the inner surface of the membrane. The Graver membrane consists of an asymmetric $\mathrm{TiO}_{2}$ layer on a sintered stainless steel support. The $\mathrm{TiO}_{2}$ layer is defined by the dark material. The $\mathrm{TiO}_{2}$ layer can be further defined by observing cracks along its surface. The support material cannot be seen in the micrograph, as it resides beneath the ceramic layer. The lighter material present on the surface of the ceramic layer is possibly residual solids or crystallized sodium hydroxide.

In general, the pore structure of the Graver membrane cannot be defined. In fact, earlier work has shown that a magnification of 20,000 or greater is needed to see the $\mathrm{TiO}_{2}$ pore structure. It is believed that the dense $\mathrm{TiO}_{2}$ layer, which provided relatively low water fluxes when compared to the other membranes evaluated, also provided relatively high fluxes with the SRS simulant. Small particles were unable to penetrate the $\mathrm{TiO}_{2}$ layer, thus producing surface filtration where the filter cake acts as the filter medium. ${ }^{(18,19)}$ 


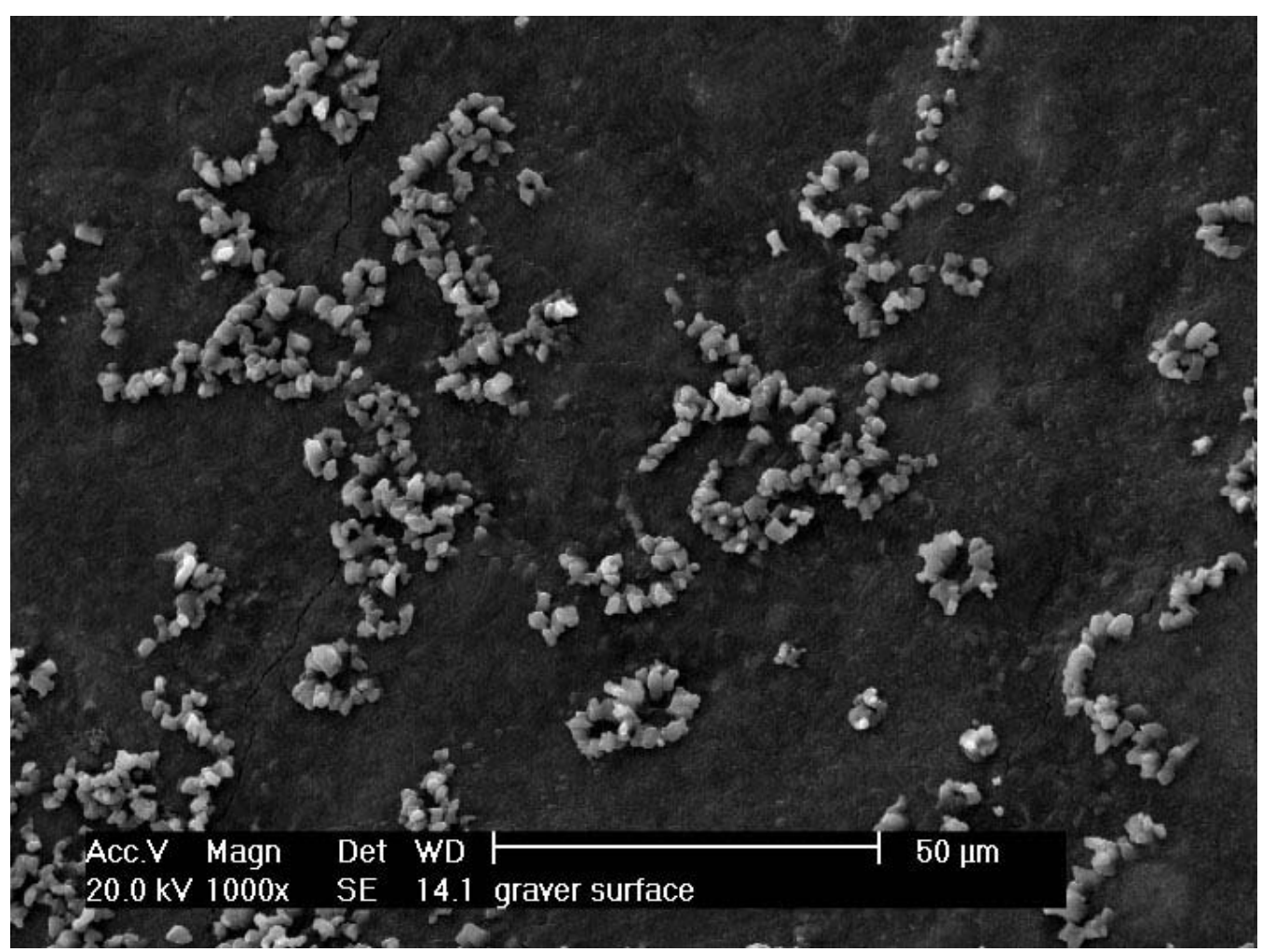

Figure 18. SEM micrograph of the Graver $0.07 \mu \mathrm{m}$ membrane at 1000X magnification.

Figures 19 and 20 display SEM micrographs of the Mott $0.1 \mu \mathrm{m}$ and Mott $0.5 \mu \mathrm{m}$ membranes at 2000X magnification. The SEM micrographs are taken at the inner surface of the membranes. The Mott membranes consist solely of sintered stainless steel as defined in the micrograph by the light globular material. A dark "cake-like" material can be observed between the sintered metal of the Mott $0.1 \mu \mathrm{m}$ membrane and is most likely residual solids. This "cake like" material can be further defined by the cracks along its surface. This dark material is not observed within the pores of the Mott $0.5 \mu \mathrm{m}$ membrane. However, due to the relatively large pore structure, this dark material may reside deeper within the pores and is not evident through SEM analysis. It should be noted that a lighter crystalline material can be observed at the pore opening of the Mott $0.5 \mu \mathrm{m}$ membrane.

In general, it is believed that the open pore structure of both Mott membranes provided relatively high water fluxes when compared to the other membranes evaluated, but provided relatively low fluxes with respect to the SRS simulant. Small particles were able to penetrate within the pore structure (as evidenced by SEM analysis), thus producing depth filtration where the porosity is greatly reduced by particles trapped within the interstices of the internal structure. ${ }^{(18,19)}$ 


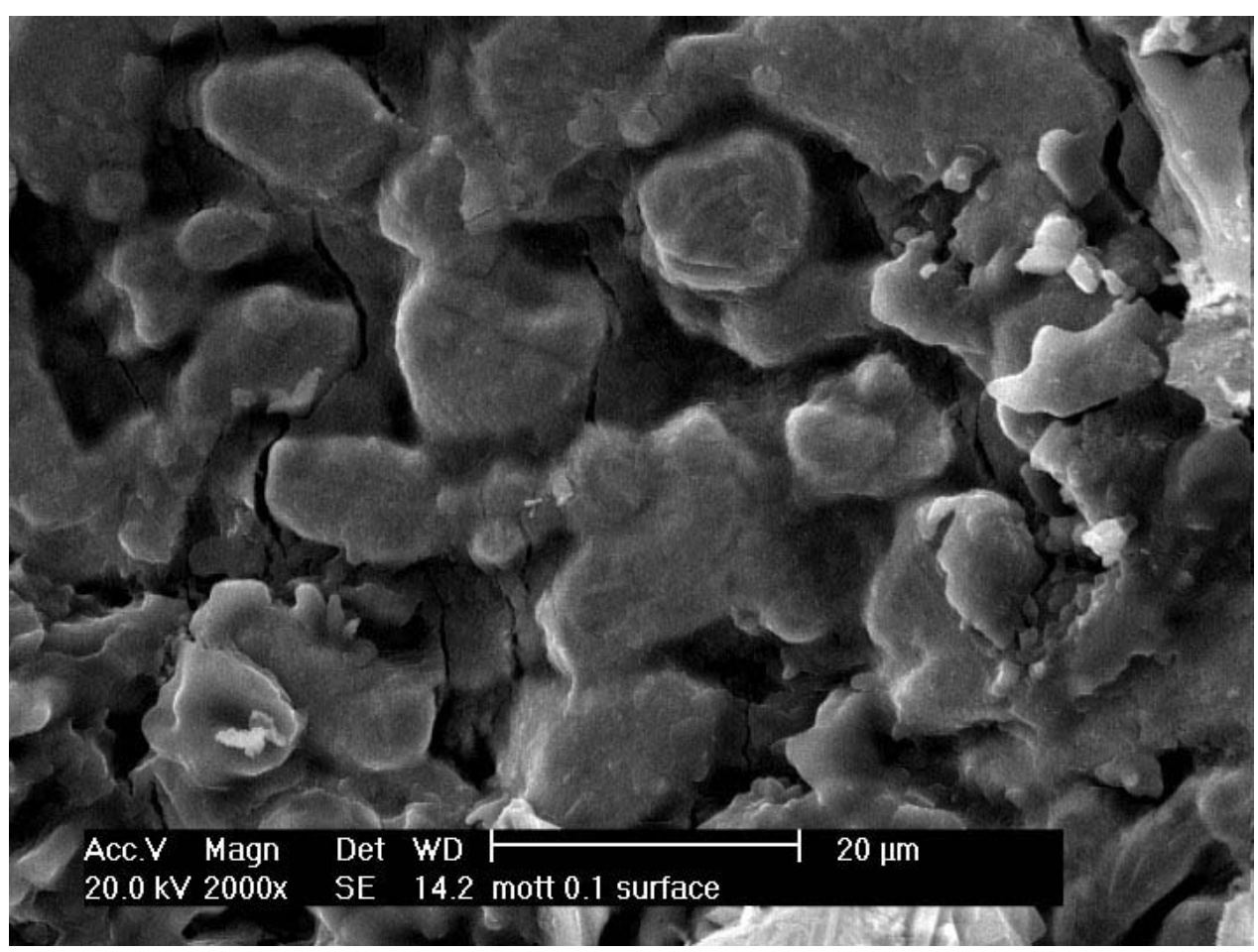

Figure 19. SEM micrograph of the Mott $0.1 \mu \mathrm{m}$ membrane at 2000X magnification.

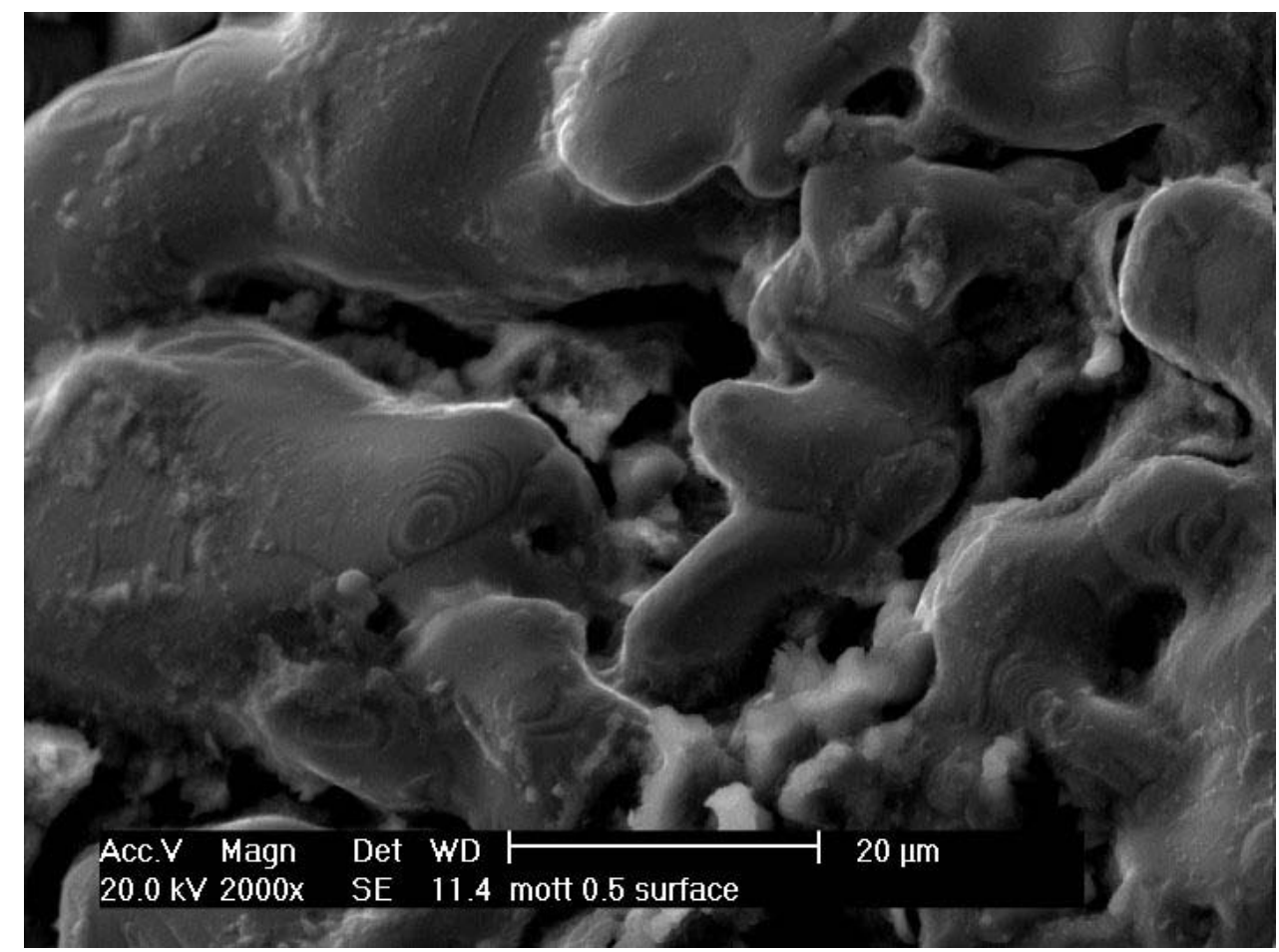

Figure 20. SEM micrograph of the Mott $0.5 \mu \mathrm{m}$ membrane at 2000X magnification. 
Figure 21 displays a SEM micrograph of the Pall $0.1 \mu \mathrm{m}$ membrane at 1000X magnification. The SEM micrograph is taken at the inner surface of the membrane. The Pall $0.1 \mu \mathrm{m}$ membrane consists of an asymmetric $\mathrm{ZrO}_{2}$ layer on a sintered stainless steel support. The $\mathrm{ZrO}_{2}$ layer is defined by the dark material. The $\mathrm{ZrO}_{2}$ layer can be further defined by observing cracks along its surface. The cracks are most likely due to the preparation (cutting and fracturing) of the sample for SEM analysis. In addition, large depressions are prevalent throughout the membrane surface and are most likely due to manufacturing. The support material cannot be seen in the micrograph since it lies beneath the $\mathrm{ZrO}_{2}$ layer. The small amount of lighter colored material present on the surface is possibly residual solids or crystallized sodium hydroxide.

In general, the pore structure of the Pall $0.1 \mu \mathrm{m}$ membrane cannot be defined. Much like the Graver membrane, it is postulated that a much higher magnification would be needed to see the $\mathrm{ZrO}_{2}$ pore structure. It is believed that the dense $\mathrm{ZrO}_{2}$ layer, which provided relatively low water fluxes when compared to the other membranes evaluated, also provided relatively high fluxes with the respect to the SRS simulant. Small particles were unable to penetrate the $\mathrm{TiO}_{2}$ layer, thus producing surface filtration where the filter cake acts as the filter medium. It should be noted that the Graver $0.07 \mu \mathrm{m}$ and Pall $0.1 \mu \mathrm{m}$ membranes observed the lowest water fluxes and the highest simulant fluxes when compared to the other membranes tested. Both membranes consist of a ceramic coating on a sintered metal support.

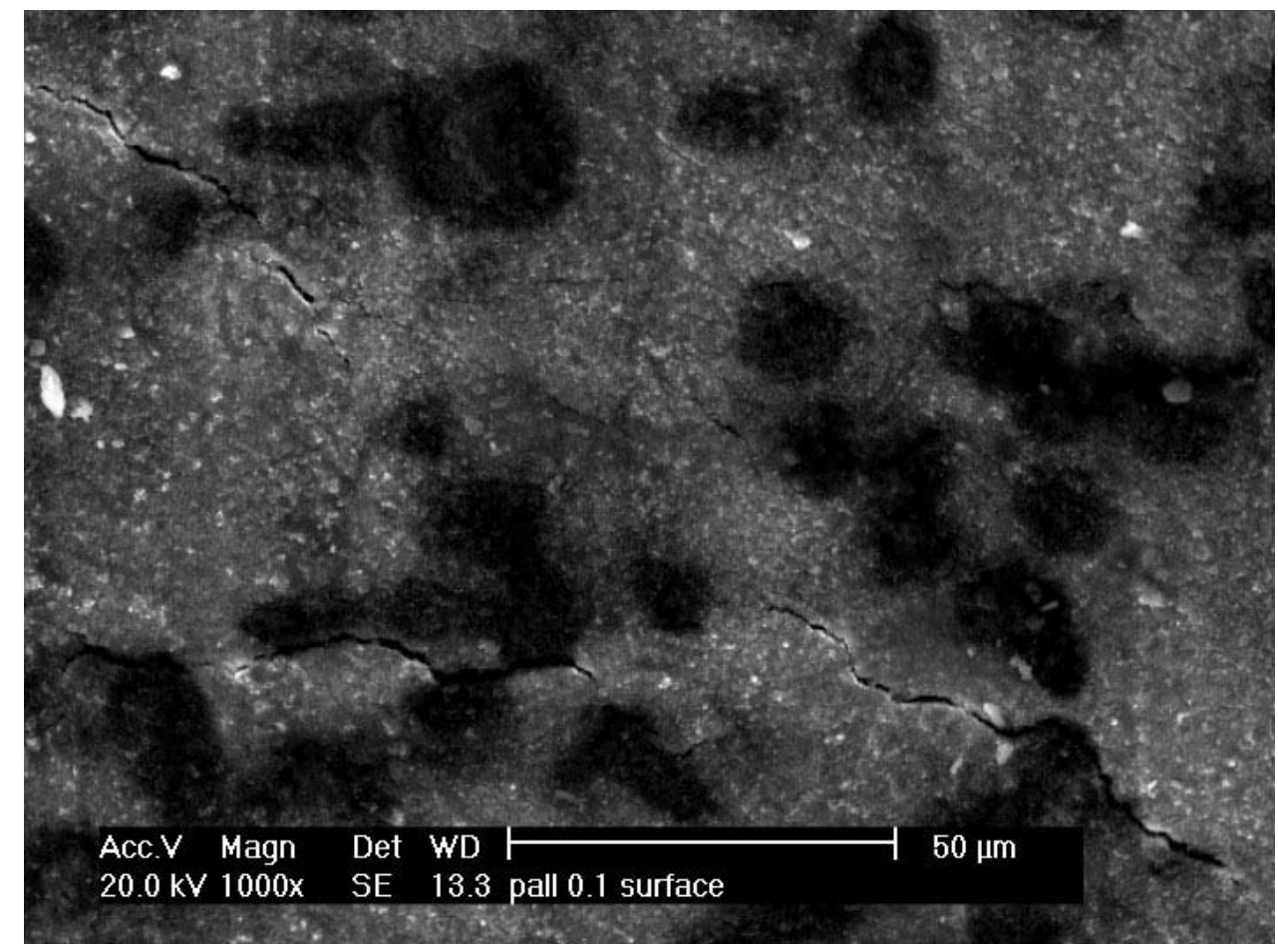

Figure 21. SEM micrograph of the Pall $0.1 \mu \mathrm{m}$ membrane at 1000X magnification.

Figure 22 displays the SEM micrograph of the GKN $0.1 \mu \mathrm{m}$ membrane at 2000X magnification. The SEM micrographs are taken at the inner surface of the membrane. The GKN membrane consists of a fine asymmetric stainless steel layer on a larger sintered stainless steel support. The GKN membrane is different in respect to the other asymmetric membranes, as the pore structure is very evident. The stainless steel asymmetric layer is not defined by the light globular material, as shown in the Mott micrographs but, light spherical material. A dark "cake-like" material can be observed between the asymmetric metal layer and is most likely fouled solids. 


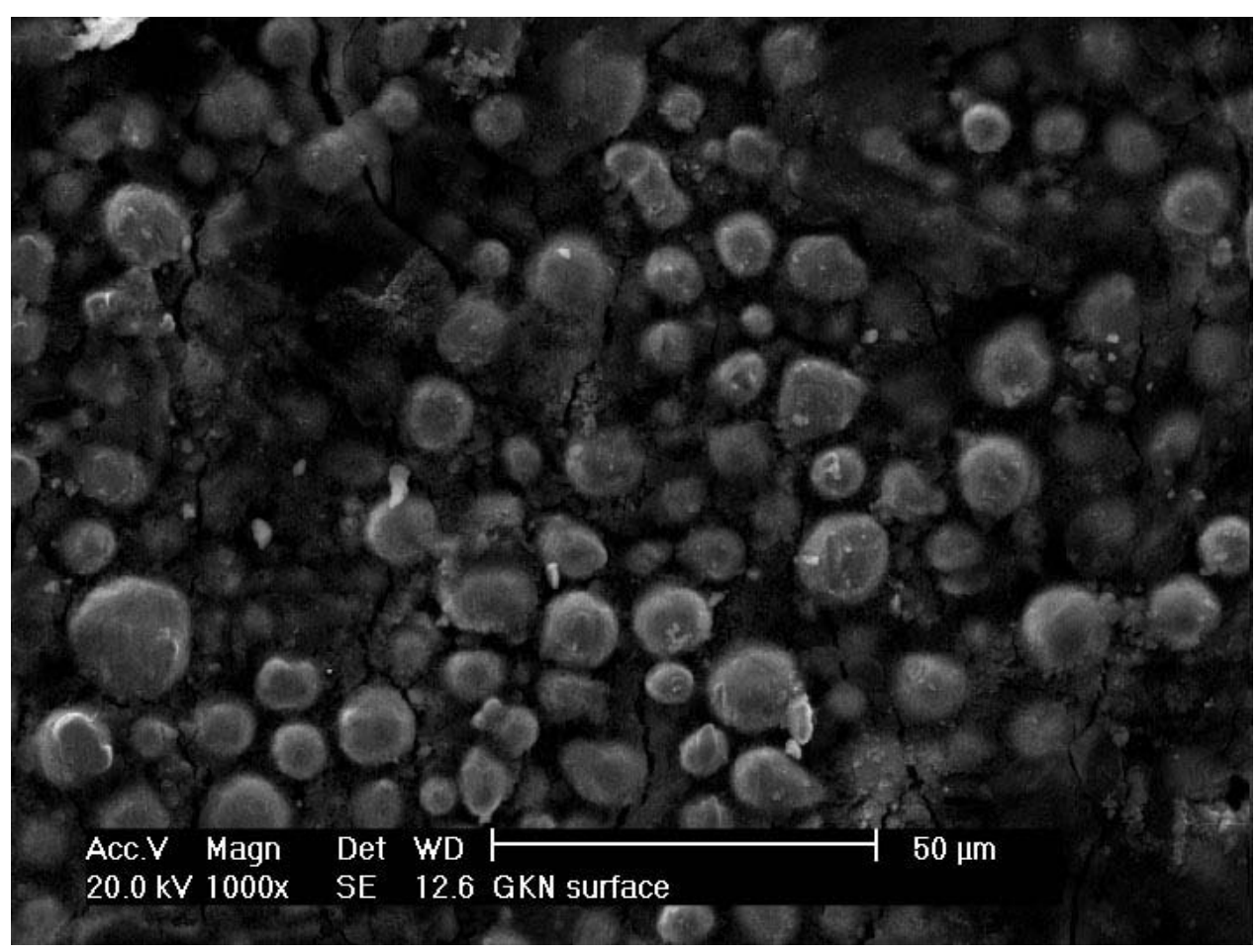

Figure 22. SEM micrograph of the GKN $0.1 \mu \mathrm{m}$ membrane at 1000X magnification.

In general, it is believed that the open pore structure of the GKN membrane provided the highest water fluxes when compared to the other membranes evaluated, but provided nearly the lowest fluxes with respect to the SRS simulant. It is postulated that the small particles were able to penetrate the spherical asymmetric layer, thus producing depth filtration where the porosity is greatly reduced by particles trapped within the interstices of the internal structure. ${ }^{(18,19)}$

The Pall $0.8 \mu \mathrm{m}$ membrane was evaluated using SEM. However, water flux could not be restored to near pristine levels despite numerous chemical and physical cleaning attempts. As a result, the Pall 0.8 $\mu \mathrm{m}$ was not included in the additional simulant tests at 0.6 and $4.5 \mathrm{wt} \%$. The Pall $0.8 \mu \mathrm{m}$ membrane was cleaned with $0.5 \mathrm{M}$ oxalic acid removing any solids present within the pore structure. Thus, the SEM micrographs depict a membrane free of any solids. A SEM of the Pall $0.8 \mu \mathrm{m}$ membrane is not shown.

\subsection{Permeate Turbidity Analysis (NTU)}

An important aspect of this evaluation was the permeate quality and whether the alternative membranes produce permeates of at least the same clarity as the baseline Mott $0.1 \mu \mathrm{m}$ membrane. The average Nephelometric Turbidity Units (NTU) and standard deviation for permeate samples are shown in Table 5. Samples of permeate were obtained during testing from the respective membranes at solids loadings of 0.29 and $4.5 \mathrm{wt} \%$. A $15 \mathrm{~mL}$ sample was obtained at test conditions 1,6 and 11 shown in the parametric test matrix in Table 2. These three measurements were averaged and are shown in Table 5. A $\mathrm{Hach}^{\circledR} 2100 \mathrm{P}$ turbidmeter was used to determine permeate quality. The turbidmeter works by transmitting a beam of light through the sample. The light beam reflects off particles in the solution, and the resultant light intensity is measured by a photodetector positioned at 90 degrees to the light beam. The detected light intensity is directly proportional to the turbidity of the solution. The Hach ${ }^{\circledR} 2100 \mathrm{P}$ turbidmeter has an analysis range of 0 to 1000 NTU. 
Table 5. The average Nephelometric Turbidity Units (NTU) and standard deviation for permeate samples for all membranes tested at 0.29 and $4.5 \mathrm{wt} \%$.

\begin{tabular}{lcccc}
\hline & \multicolumn{3}{c}{$0.29 \mathrm{wt} \%$} & \multicolumn{2}{c}{$4.5 \mathrm{wt} \%$} \\
\cline { 2 - 5 } Membrane & Average NTU & $\begin{array}{c}\text { Average Std. } \\
\text { Deviation }\end{array}$ & $\begin{array}{c}\text { Average NTU } \\
\text { Deviation }\end{array}$ \\
\hline Graver $0.07 \mu \mathrm{m}$ & 2.4 & 0.21 & 0.6 & 0.04 \\
Mott $0.1 \mu \mathrm{m}$ & 2.8 & 0.21 & 0.7 & 0.05 \\
Mott $0.5 \mu \mathrm{m}$ & 1.1 & 0.09 & 0.4 & 0.02 \\
Pall $0.1 \mu \mathrm{m}$ & 0.9 & 0.05 & 0.6 & 0.03 \\
Pall $0.8 \mu \mathrm{m}$ & 0.3 & 0.05 & 0.4 & 0.03 \\
GKN $0.1 \mu \mathrm{m}$ & 1.9 & 0.08 & 1.0 & 0.03 \\
\hline
\end{tabular}

The main objective of the NTU analysis was to compare the permeate quality to the baseline Mott $0.1 \mu \mathrm{m}$ membrane. The maximum acceptable turbidity measurement is 5-10 NTU. ${ }^{(3)}$ Referring to Table 5, NTU measurements of 2.8 and 0.7 at 0.29 and $4.5 \mathrm{wt} \%$, respectively were obtained with the Mott $0.1 \mu \mathrm{m}$ membrane. At $0.29 \mathrm{wt} \%$ the baseline Mott $0.1 \mu \mathrm{m}$ displayed the highest NTU and at $4.5 \mathrm{wt} \%$ displayed the second highest NTU measurement. The highest NTU measurement obtained was with the GKN 0.1 $\mu \mathrm{m}$ membrane at $4.5 \mathrm{wt} \%$. All alternative membranes provided reduced or equivalent turbidity measurements when compared to the baseline Mott $0.1 \mu \mathrm{m}$ membrane. 


\section{COST BENEFIT ANALYSIS}

Filter manufacturers, Graver Technologies, Pall Corporation and GKN were each requested to provide a budgetary quote for a retrofit filter bundle and associated housing to replace the existing crossflow filter (Hypulse LSX) located in 512-S. Each manufacturer was provided with drawings of the existing filter (7020346 Rev D and S511-205-030-00-F) as provided by SRNL. The overall length of the retrofit housing and total area $\left(\mathrm{ft}^{2}\right)$ of the filter bundle was to remain unchanged. However, some alteration could be made to the diameter of the filter housing. Moreover, manufacturers were provided with the necessary operational parameters (AV, TMP, pressures, etc.) and waste specifications (PSD, viscosity, density, etc.) to complete the budgetary quote. Table 6 compares the budgetary quote for the Graver $(0.07 \mu \mathrm{m})$, Pall $(0.1 \mu \mathrm{m}$ and $0.8 \mu \mathrm{m}) \mathrm{GKN}(0.1 \mu \mathrm{m})$ and Mott $(0.1 \mu \mathrm{m})$ filter products. Graver, Pall and GKN provided estimates based on replacing the existing Mott filters in 512-S with their technology. The proposal includes the supply of a housing and membrane filter bundle for retrofit into the previously installed crossflow filter in 512-S.

Table 6. Budgetary quote for retrofit into the existing crossflow filter located in 512-S.

$\begin{array}{lc}\text { Membrane } & \text { Budgetary Quote }(\$) \\ \text { Graver } 0.07 \mu \mathrm{m} & 44,000.00 \\ \text { Pall } 0.1 \mu \mathrm{m} & 100,000.00 \\ \text { Pall } 0.8 \mu \mathrm{m} & 140,000.00 \\ \text { GKN } 0.1 \mu \mathrm{m} & 475,000.00 \\ \text { Mott } 0.1 \mu \mathrm{m} & 270,000.00\end{array}$

Reproductions of the actual budgetary quotes obtained from Graver, Pall and GKN are shown in Tables 1, 2 and 3 of Appendix I. An added engineering design cost was added to the quote provided by GKN. This cost is a one-time cost for multiple housings. It should be noted that an engineering design cost is already included in the quotes provided by Pall Corporation and Graver Technologies. In addition, three quotes were supplied by Graver Technologies. However, option 1C should be used in this cost benefit analysis since it is closest to the current design. A budgetary quote for the Mott $0.1 \mu \mathrm{m}$ was provided by SRNL and is shown in Table 4 of Appendix I as a personal email. 


\section{POTENTIAL IMPACTS ON HIGH LEVEL WASTE PROCESSING}

The Pall and Graver filters offer increased flux over the 0.1 and $0.5 \mu \mathrm{m}$ Mott filters. As part of the development of the rotary microfilter, the authors investigated the impact of the technology on the SRS High Level Waste system.

The Pall and Graver filters add no new chemicals to the actinide removal process. With the technology, the feed to 512-S is contacted with monosodium titanate (MST) for as long as 24 hours, and filtered to remove the strontium and actinide species that sorb to the MST.

The Pall and Graver filters produce higher throughput, so they will facilitate faster treatment of the SRS High Level Waste that needs alpha removal. The flowsheet for the these filters shows that replacing the $0.5 \mu \mathrm{m}$ crossflow filter in 512-S with the same size Pall or Graver filter would increase the annual throughput of 512-S by $3-6 \%$ (assuming a $24 \mathrm{hr}$ MST strike). If the MST contact, or strike, time is reduced to 4 hours, the degree of improved throughput with the Pall and Graver filters increases further (6 $-12 \%$ ). If the MST contact, or strike, time is reduced to 0 hours, the degree of improved throughput with the Pall and Graver filters increases even further $(8-16 \%){ }^{(20)}$

Since the Pall and Graver filters produce higher filter flux than the baseline crossflow filter technology, they will likely require less frequent chemical cleaning, and add fewer cleaning chemicals, such as oxalic acid, to the SRS High Level Waste System.

The Pall and Graver filters have the following positive impacts to the SRS High Level Waste System:

- They add no new chemicals to the actinide removal process:

- $\quad$ The Pall and Graver filters will require less frequent chemical cleaning, so they add fewer cleaning chemicals to the SRS High Level Waste System.

- $\quad$ The Pall and Graver filters produce higher filtrate throughput, so they will allow faster treatment of the SRS High Level Waste needing actinide removal. Replacing the crossflow filter in 512-S with an equivalent sized Pall or Graver filter would increase the ARP processing rate by $3-16 \%$, depending on the MST strike time.

The Pall and Graver filters have the following negative impacts to the SRS High Level Waste System:

- $\quad$ There is a cost to procure the new filters and to install them in 512-S, and the replacement would require time.

- We would lose the historical database that we have built from all of the testing with 0.1 and $0.5 \mu \mathrm{m}$ Mott filter media. 


\section{COMPONENTS OF FUTURE WORK}

The authors recommend that the following additional testing be performed with membranes to confirm improved performance observed in these tests: actual waste filtration tests, pilot-scale filtration tests, and filter cleaning tests. SRNL should conduct bench-scale testing with actual waste using both the $0.1 \mu \mathrm{m}$ Pall filter media and the $0.07 \mu \mathrm{m}$ Graver media. In addition to the actual waste testing, SRNL should conduct pilot-scale testing with the Pall or Graver media. Moreover, additional bench-scale and pilot-scale testing should include the Mott $0.1 \mu \mathrm{m}$ media as a basis of comparison. The media selected for the pilot-scale testing should be based upon the results of the current tests and the actual waste tests. The actual waste and pilot-scale filtration tests should include an evaluation of filter cleaning for each media tested. 


\section{NEW AND EXISTING FACILITIES}

The Pall or Graver filters would be placed in the existing 512-S facility. The vendors have provided estimates based on replacing the existing filters in 512-S with their technology. 


\section{RISK ASSESSMENT}

If we replace the Mott $0.1 \mu \mathrm{m}$ filter with the Pall or Graver filters, we lose the historical test database that includes bench-scale simulant testing, actual waste testing and pilot-scale simulant testing. The database also includes sludge only feed, sludge plus MST and sludge plus manganese dioxide feed. 


\section{CONCLUSIONS}

Membrane variation data indicate that membranes having an asymmetric ceramic coating (Pall $0.1 \mu \mathrm{m}$ and Graver $0.07 \mu \mathrm{m}$ ), typically displayed the lowest variability with water. Membranes without a ceramic asymmetric coating (Mott $0.1 \mu \mathrm{m}$, Mott $0.5 \mu \mathrm{m}$, Pall $0.8 \mu \mathrm{m}$, and GKN $0.1 \mu \mathrm{m}$ ), displayed the highest variability, which is most likely associated with the experimental uncertainties in measuring large volumes of permeate in a short amount of time. Statistical analysis of variance techniques (ANOVA) applied to the complete set of water flux data indicate no statistical differences are associated among the five modules within each manufacture. In the case of variation testing using strontium carbonate, variability decreased to $3-12 \%$ as compared with the water flux. In addition, membrane structure or composition had little effect on the variability.

Data obtained from SRS simulant testing, indicate that membranes having a ceramic asymmetric coating (Pall $0.1 \mu \mathrm{m}$ and Graver $0.07 \mu \mathrm{m}$ ), achieved the highest average steady state fluxes for all solids loadings evaluated. In general, the Graver and Pall membranes achieved fluxes nearly 13 to 21 percent higher than those observed with the baseline Mott $0.1 \mu \mathrm{m}$ membrane at solids loadings of 0.29 and 4.5 $\mathrm{wt} \%$. It is postulated that small particles present in solution were unable to penetrate the ceramic layer, thus producing surface filtration where the filter cake acts as the filter medium. Conversely, membranes without the ceramic asymmetric coating were susceptible to the small particles present in solution penetrating into the internal pore structure of the membrane, thus producing depth filtration where the porosity is greatly reduced by particles trapped within the interstices of the internal structure. Statistical analyses (with JMP software) of the simulant flux data indicate that the insoluble solids concentration and axial velocity had the strongest effect on filter flux, and that the effects are statistically significant. The analysis also shows the transmembrane pressure and filter media have statistically significant effects on filter flux, but the effects are less than the effects of insoluble solids concentration and axial velocity. Statistical comparative analysis among various alternative membranes indicate that the Pall $0.1 \mu \mathrm{m}$ and Mott $0.1 \mu \mathrm{m}$ membranes are statistically different. In addition, the Graver $0.07 \mu \mathrm{m}$ and Mott $0.1 \mu \mathrm{m}$ are also statistically different. Conversely, the Pall $0.1 \mu \mathrm{m}$ and the Graver $0.07 \mu \mathrm{m}$ filters were determined to be statistically the same. Also, the Mott $0.5 \mu \mathrm{m}$ and Mott $0.1 \mu \mathrm{m}$ membranes were determined to be statistically the same.

After close examination of INEEL simulant flux data performed at $4.5 \mathrm{wt} \%$, it was speculated that a discrepancy between the INEEL and prior SRNL data existed. Personnel from the SRNL and USC had previously conducted engineering-scale filtration tests using the FRED facility and the Mott $0.1 \mu \mathrm{m}$ membrane. As a basis of comparison, additional tests were performed with SRS simulated waste at solids loadings of 0.06 and $4.5 \mathrm{wt} \%$. Two test conditions were changed. Operating temperatures were increased from $25^{\circ} \mathrm{C}$ to $35^{\circ} \mathrm{C}$ and backpulse pressures were adjusted from 40 psig to $90 \mathrm{psig}$. The additional flux data indicate that the fluxes obtained with the Graver $0.07 \mu \mathrm{m}$ and the Pall $0.1 \mu \mathrm{m}$ were $11-31 \%$ higher when compared to the baseline Mott $0.1 \mu \mathrm{m}$ membrane. However, despite tests being performed in replication of tests performed at SRNL (FRED facility), flux values obtained at the INEEL were approximately 26 percent lower. The discrepancies were discovered to be a difference in simulant test solutions, specifically solids loading and particle size diameter. The solids loadings of test solutions utilized at the INEEL were approximately $33 \%$ higher than those tested at the FRED facility. Actual test solutions were calculated at $0.09,0.43$ and $6.7 \mathrm{wt} \%$, respectively. In addition, PSD analysis displayed more fine particles $(<1$ micron) present in test solutions utilized at the INEEL. Statistical analysis of the data collected at $35^{\circ} \mathrm{C}$ indicate that the insoluble solids concentration and axial velocity have the strongest effect on filter flux, and that the effects are statistically significant. The analysis also shows the transmembrane pressure and filter media have statistically significant effects on filter flux, but the effects are less than the effects of insoluble solids concentration and axial velocity. 
Turbidity data indicate that permeate from the alternative membranes provided reduced or equivalent turbidity measurements when compared to the baseline $0.1 \mu \mathrm{m}$ Mott. All filters produced acceptable turbidity.

The authors recommend that additional testing be performed with the Pall $0.1 \mu \mathrm{m}$ and Graver 0.07 $\mu \mathrm{m}$ membranes to validate the improved performance observed in these tests. Additional testing should also include the Mott $0.1 \mu \mathrm{m}$ membrane as a basis of comparison. Testing should include actual waste, pilot-scale and filter cleaning tests. The media selected for the pilot-scale testing should be based upon the results of the current tests and the actual waste tests. The actual waste and pilot-scale filtration tests should include an evaluation of filter cleaning for each media tested. 


\section{REFERENCES}

1. J. A. Gantt, E. P. Gatzke, V. Van Brunt, R. Haggard, T. Deal, C. Stork, M. R. Poirier, and S. D. Fink, Modeling Pilot-Scale Crossflow Filtration of Simulated Nuclear Waste, 2002 AICHE Annual Meeting.

2. J. A. Gantt, E. P. Gatzke, V. Van Brunt, R. Haggard, T. Deal, C. Stork, M. R. Poirier, and S. D. Fink, Modeling and Operation of Pilot-Scale Crossflow Filtration of Simulated Nuclear Waste, 2002 AICHE Annual Meeting.

3. M. R. Poirier and S. D. Fink, "Recommendation for Using Smaller $(0.1 \mu \mathrm{m})$ Pore-Size Media for Filtration in Salt Waste Processing Project," WSRC-TR-2002-00341, August 5, 2002.

4. M. R. Poirier, T. M. Jones, S. D. Fink, R. Haggard, and V. Van Brunt, "Evaluation of Mott Filter Performance," WSRC-TR-2002-00256, May 30, 2002.

5. M. R. Poirier, J. L. Siler, and S. D. Fink, "Filtration of Actual Savannah River Site Waste Treated with Permanganate or Monosodium Titanate," WSRC-TR-2002-00134, March 14, 2002.

6. V. Van Brunt, R. Haggard, T. Deal, C. Stork, M. R. Poirier, and S. D. Fink, "Cross-Flow Filtration of Simulated High-Level Waste Sludge (Tank 8F),” WSRC-TR-2001-00195, April 20, 2001.

7. M. R. Poirier, F. F. Fondeur, T. L. Fellinger, and S. D. Fink "Cross-Flow Filtration Demonstration for Slurries Containing High Level Waste Sludge and Monosodium Titanate," WSRC-TR-200100212, April 11, 2001.

8. M. R. Poirier, “FY2000 Fred Test Report,” WSRC-TR-2001-00035, January 11, 2001.

9. H. H. Saito, M. R. Poirier, and J. L. Siler, "Effect of Sludge Solids to Mono-Sodium Titanate (MST) Ratio on MST - Treated Sludge Slurry Cross-Flow Filtration Rates," WSRC-TR-99-00342, September 15, 1999.

10. H. H. Saito, M. R. Poirier, S. W. Rosencrance, and J. L. Siler, "Improving Filtration Rates of Mono-Sodium Titanate (MST)-Treated Sludge Slurry with Chemical Additives", WSRC-TR-9900343, September 15, 1999.

11. M. R. Poirier, "Crossflow Filtration of Slurries Containing Savannah River Site High Level Waste Sludge and Monosodium Titanate," WSRC-MS-2003-00241, 2003 AICHE Spring Meeting, New Orleans, March 31, 2003.

12. M. R. Poirier, J. L. Siler, S. D. Fink, R. Haggard, T. Deal, C. Stork, and V. Van Brunt, "Pilot-Scale Testing of a 0.1 Micron Filter with SRS Simulated High Level Waste", WSRC-TR-2003-00469, October 8, 2003.

13. Garn, T. G., Mann N. R., Herbst, R. S., Todd, T. A., "Experimental Comparison of Mott, GKN, Pall, and Graver Ultrafiltration Membranes using Envelope A (AN-105) and Envelope D (AZ-101) Hanford Simulants," INEEL/EXT-03-00887, July 2003

14. Walker, B. W., McCabe, D., "Crossflow filtration of Department of Energy Hanford Waste Streams using Sintered Metal Mott and Graver Filters at the Savannah River Technology Center," WSRC-MS-98-00039, May 1998 
15. Mann, N. R., Garn, T. G., Herbst, R. S., Todd, T. A., "Investigation of an Ultrafiltration Chemical Cleaning Sequence for Hanford Simulated Tank Waste; Env. A (AN-105), Env. C (AN-102) and Env. D (AZ-101),” INEEL/EXT-03-00886, July 2003.

16. M. C. Porter, Handbook of Industrial Membrane Technology, Park Ridge, Noyes, Appendix 19.

17. T. Carroll, S. King, S. R. Gray, B. A. Bolto, and N. A. Booker, "The Fouling of Microfiltration Membranes by NOM after Coagulation Treatment," Wat. Res. Vol. 34, no. 11, pp. 2861-2868, 2000 .

18. Svarovsky, L., ed. Solid-Liquid Separation, Third Edition, Cambridge, Butterworths \& Co, 1990.

19. Dickenson, C. T. Filters and Filtration Handbook, Forth Edition, Oxford, Elsevier Science Ltd, 1997.

20. K. B. Martin, M. R. Poirier, S. G. Subosits, S. D. Fink, "Evaluation of Alternative Filter Media on the Actinide Removal Process Flowsheet," WSRC-TR-2004-00301, June 2004. 


\section{Appendix A \\ Strontium Carbonate Recipe}




\section{Appendix A \\ Strontium Carbonate Recipe}

Table A-1. Strontium carbonate recipe.

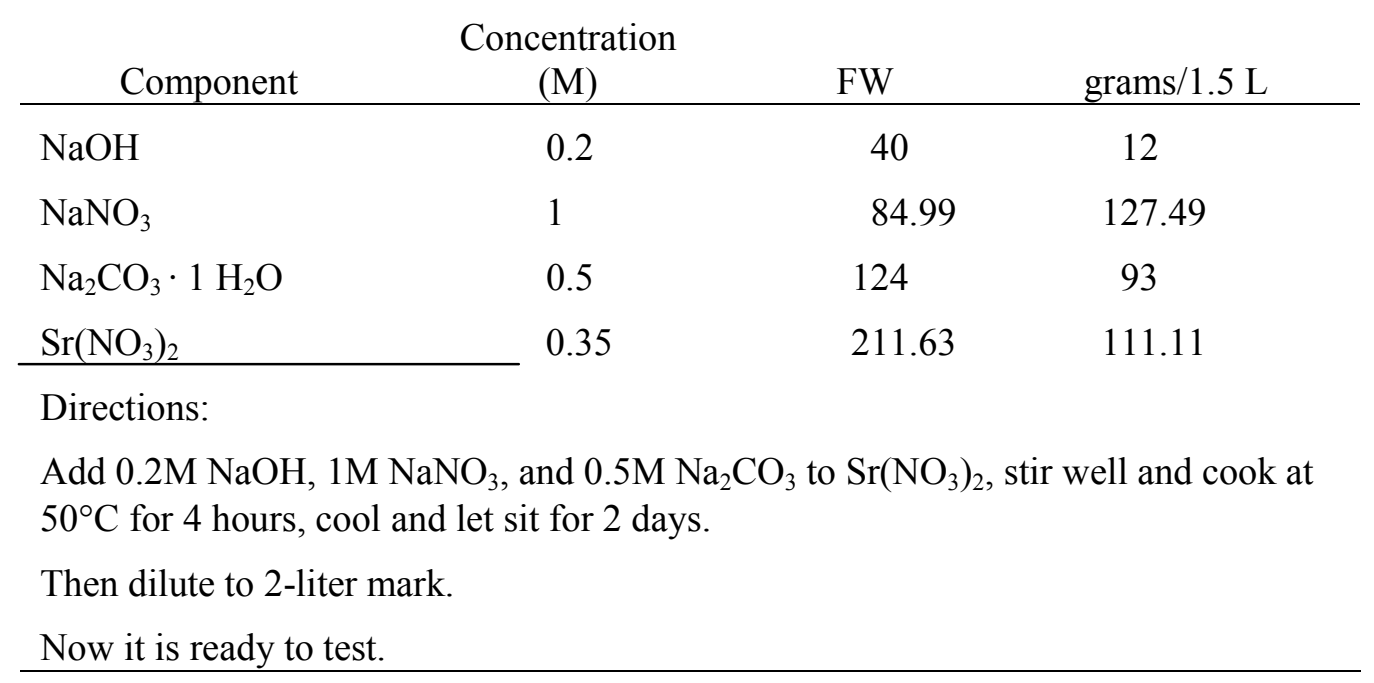


Appendix B

JMP Statistical Analysis 


\section{Appendix B}

\section{JMP Statistical Analysis}

The analysis of variance table shows the basic statistical calculations for a linear model. Since 132 tests were conducted and one degree of freedom is used to calculate the mean, there are 131 degrees of freedom to calculate the variance. Since three replicates of the center point were performed with each filter membrane and each solids loading, the analysis had 24 degrees of freedom to calculate the random error ( 2 from replicates x 6 filters x 2 solids loadings $=24$ ). The remaining 99 degrees of freedom were used to develop the model. The JMP software calculated the variance in the flux due to the model and the variance in the flux due to random error. Each variance was divided by the number of degrees of freedom, and the ratio of the mean variances was calculated to produce an $\mathrm{F}$ ratio. The software calculated the probability of obtaining a greater $F$ value by chance alone. If the probability is less than 0.05 , the model contains at least one significant regression factor (with 95\% confidence).

The parameter effects table shows the estimates of each parameter in the model and a t test for the hypothesis that each parameter is zero. The Prob $>|t|$ is the probability of obtaining an even greater $t$ statistic, given the hypothesis that the parameter is zero. If the probability is less than 0.05 , the parameter is not zero (with $95 \%$ confidence).

The effects test table shows the results of tests conducted to determine whether the individual effects are zero. Continuous effects have one parameter, and nominal effects have one less parameter than the number of levels. Ordinarily the degrees of freedom and the number of parameters are the same. The sum of squares is the variance due to the effect in the model. The F ratio is the ratio of the mean square for the effect divided by the mean square for the error. Prob $>\mathrm{F}$ is the probability that the null hypothesis is true (i.e., the variance measured is due to random error). Values less than 0.05 indicate the effect is statistically significant (with $95 \%$ confidence). 
Table B-1. Statistical Analysis of All Filter Media.

Response Flux

Whole Model

$\underline{\text { Summary of Fit }}$

RSquare $\quad 0.750206$

RSquare Adj $\quad 0.733959$

Root Mean Square Error $\quad 24.64512$

Mean of Response $\quad 113.0465$

Observations (or Sum Wgts) 132

Analysis of Variance

$\begin{array}{lllll}\text { Source } & \text { DF } & \text { Sum of Squares } & \text { Mean Square } & \text { F Ratio } \\ \text { Model } & 8 & 224370.02 & 28046.3 & 46.1757 \\ \text { Error } & 123 & 74707.96 & 607.4 & \text { Prob }>F^{*} \\ \text { C. Total } & 131 & 299077.97 & & <.0001\end{array}$

\section{Lack Of Fit}

$\begin{array}{lllll}\text { Source } & \text { DF } & \text { Sum of Squares } & \text { Mean Square } & \text { F Ratio } \\ \text { Lack Of Fit } & 99 & 41992.455 & 424.17 & 0.3112 \\ \text { Pure Error } & 24 & 32715.501 & 1363.15 & \text { Prob }>F^{*} \\ \text { Total Error } & 123 & 74707.956 & & 1.0000 \\ & & & & \text { Max RSq } \\ & & & & 0.8906\end{array}$

$\underline{\text { Parameter Estimates }}$

$\begin{array}{lllll}\text { Term } & \text { Estimate } & \text { Std Error } & \mathrm{t} \text { Ratio } & \text { Prob }>|\mathrm{t}|^{*} \\ \text { Intercept } & 27.574706 & 10.56861 & 2.61 & 0.0102 \\ \text { TIS } & -12.27107 & 1.019041 & -12.04 & <.0001 \\ \text { TMP } & 7.4986542 & 3.536548 & 2.12 & 0.0360 \\ \text { Vel } & 36.221476 & 2.515297 & 14.40 & <.0001 \\ \text { Filter[0.1 Mott] } & -9.885606 & 4.796549 & -2.06 & 0.0414 \\ \text { Filter[0.1 Pall] } & 9.2712121 & 4.796549 & 1.93 & 0.0555 \\ \text { Filter[0.5 Mott] } & -10.07106 & 4.796549 & -2.10 & 0.0378 \\ \text { Filter[0.8 Pall] } & 3.6721212 & 4.796549 & 0.77 & 0.4454 \\ \text { Filter[GKN] } & 0.1321212 & 4.796549 & 0.03 & 0.9781\end{array}$


Table B-1. Statistical Analysis of All Filter Media (continued).

$\underline{\text { Effect Tests }}$

$\begin{array}{llllll}\text { Source } & \text { Nparm } & \text { DF } & \text { Sum of Squares } & \text { F Ratio } & \text { Prob }>F^{*} \\ \text { TIS } & 1 & 1 & 88073.07 & 145.0045 & <.0001 \\ \text { TMP } & 1 & 1 & 2730.67 & 4.4958 & 0.0360 \\ \text { Vel } & 1 & 1 & 125954.98 & 207.3737 & <.0001 \\ \text { Filter } & 5 & 5 & 7611.12 & 2.5062 & 0.0338\end{array}$

Filter

Least Squares Means Table

$\begin{array}{llll}\text { Level } & \text { Least Sq Mean } & \text { Std Error } & \text { Mean } \\ 0.1 \text { Mott } & 103.16091 & 5.2543564 & 103.161 \\ 0.1 \text { Pall } & 122.31773 & 5.2543564 & 122.318 \\ 0.5 \text { Mott } & 102.97545 & 5.2543564 & 102.975 \\ 0.8 \text { Pall } & 116.71864 & 5.2543564 & 116.719 \\ \text { GKN } & 113.17864 & 5.2543564 & 113.179 \\ \text { Graver } & 119.92773 & 5.2543564 & 119.928\end{array}$

Values less than 0.05 indicate statistically significant effects 
Table B-2. Statistical Analysis of $0.1 \mu \mathrm{m}$ Pall and $0.1 \mu \mathrm{m}$ Mott Media.

Response Flux

Whole Model

$\underline{\text { Summary of Fit }}$

RSquare $\quad 0.749622$

RSquare Adj $\quad 0.723942$

Root Mean Square Error $\quad 25.6317$

Mean of Response 112.7393

Observations (or Sum Wgts) $\quad 44$

Analysis of Variance

$\begin{array}{lllll}\text { Source } & \text { DF } & \text { Sum of Squares } & \text { Mean Square } & \text { F Ratio } \\ \text { Model } & 4 & 76712.48 & 19178.1 & 29.1912 \\ \text { Error } & 39 & 25622.37 & 657.0 & \text { Prob }>F^{*} \\ \text { C. Total } & 43 & 102334.85 & & <.0001\end{array}$

Lack Of Fit

$\begin{array}{lllll}\text { Source } & \text { DF } & \text { Sum of Squares } & \text { Mean Square } & \text { F Ratio } \\ \text { Lack Of Fit } & 31 & 14141.263 & 456.17 & 0.3179 \\ \text { Pure Error } & 8 & 11481.105 & 1435.14 & \text { Prob }>F^{*} \\ \text { Total Error } & 39 & 25622.368 & & 0.9900 \\ & & & & \text { Max RSq } \\ & & & & 0.8878\end{array}$

$\underline{\text { Parameter Estimates }}$

$\begin{array}{lllll}\text { Term } & \text { Estimate } & \text { Std Error } & \text { t Ratio } & \text { Prob }>|t|^{*} \\ \text { Intercept } & 24.426162 & 19.03815 & 1.28 & 0.2071 \\ \text { TIS } & -11.74401 & 1.835688 & -6.40 & <.0001 \\ \text { TMP } & 6.5130541 & 6.370692 & 1.02 & 0.3129 \\ \text { Vel } & 37.540719 & 4.531025 & 8.29 & <.0001 \\ \text { Filter[0.1 Mott] } & -9.578409 & 3.864123 & -2.48 & 0.0176\end{array}$


Table B-2. Statistical Analysis of $0.1 \mu \mathrm{m}$ Pall and $0.1 \mu \mathrm{m}$ Mott Media (continued).

$\underline{\text { Effect Tests }}$

$\begin{array}{llllll}\text { Source } & \text { Nparm } & \text { DF } & \text { Sum of Squares } & \text { F Ratio } & \text { Prob }>F^{*} \\ \text { TIS } & 1 & 1 & 26889.922 & 40.9294 & <.0001 \\ \text { TMP } & 1 & 1 & 686.674 & 1.0452 & 0.3129 \\ \text { Vel } & 1 & 1 & 45099.009 & 68.6455 & <.0001 \\ \text { Filter } & 1 & 1 & 4036.821 & 6.1445 & 0.0176\end{array}$

Filter

Least Squares Means Table

Level Least Sq Mean

$\begin{array}{ll}\text { Std Error } & \text { Mean } \\ 5.4646958 & 103.161 \\ 5.4646958 & 122.318\end{array}$

* Values less than 0.05 indicate statistically significant effects 
Table B-3. Statistical Analysis of Graver and $0.1 \mu \mathrm{m}$ Mott Media.

Response Flux

Whole Model

$\underline{\text { Summary of Fit }}$

RSquare $\quad 0.775697$

RSquare Adj $\quad 0.752692$

Root Mean Square Error $\quad 23.68235$

Mean of Response 111.5443

Observations (or Sum Wgts) $\quad 44$

Analysis of Variance

$\begin{array}{lllll}\text { Source } & \text { DF } & \text { Sum of Squares } & \text { Mean Square } & \text { F Ratio } \\ \text { Model } & 4 & 75643.413 & 18910.9 & 33.7180 \\ \text { Error } & 39 & 21873.294 & 560.9 & \text { Prob }>F^{*} \\ \text { C. Total } & 43 & 97516.706 & & <.0001\end{array}$

Lack Of Fit

$\begin{array}{lllll}\text { Source } & \text { DF } & \text { Sum of Squares } & \text { Mean Square } & \text { F Ratio } \\ \text { Lack Of Fit } & 31 & 11126.270 & 358.91 & 0.2672 \\ \text { Pure Error } & 8 & 10747.024 & 1343.38 & \text { Prob }>F^{*} \\ \text { Total Error } & 39 & 21873.294 & & 0.9964 \\ & & & & \text { Max RSq } \\ & & & 0.8898\end{array}$

$\underline{\text { Parameter Estimates }}$

$\begin{array}{lllll}\text { Term } & \text { Estimate } & \text { Std Error } & \mathrm{t} \text { Ratio } & \text { Prob }>|\mathrm{t}|^{*} \\ \text { Intercept } & 27.39599 & 17.59026 & 1.56 & 0.1274 \\ \text { TIS } & -12.69499 & 1.69608 & -7.48 & <.0001 \\ \text { TMP } & 8.5259228 & 5.886187 & 1.45 & 0.1555 \\ \text { Vel } & 35.334144 & 4.18643 & 8.44 & <.0001 \\ \text { Filter[0.1 Mott] } & -8.383409 & 3.570249 & -2.35 & 0.0240\end{array}$


Table B-3. Statistical Analysis of Graver and $0.1 \mu \mathrm{m}$ Mott Media (continued).

Effect Tests

$\begin{array}{llllll}\text { Source } & \text { Nparm } & \text { DF } & \text { Sum of Squares } & \text { F Ratio } & \text { Prob }>F^{*} \\ \text { TIS } & 1 & 1 & 31421.117 & 56.0237 & <.0001 \\ \text { TMP } & 1 & 1 & 1176.696 & 2.0980 & 0.1555 \\ \text { Vel } & 1 & 1 & 39953.146 & 71.2363 & <.0001 \\ \text { Filter } & 1 & 1 & 3092.388 & 5.5137 & 0.0240\end{array}$

Filter

Least Squares Means Table

Level Least Sq Mean

$\begin{array}{ll}\text { Std Error } & \text { Mean } \\ 5.0490939 & 103.161 \\ 5.0490939 & 119.928\end{array}$

0.1 Mott 103.16091

$5.0490939-119.928$

* Values less than 0.05 indicate statistically significant effects 
Table B-4. Statistical Analysis of $0.1 \mu \mathrm{m}$ Pall and Graver Media.

Response Flux

Whole Model

Summary of Fit

$\begin{array}{ll}\text { RSquare } & 0.759814 \\ \text { RSquare Adj } & 0.73518 \\ \text { Root Mean Square Error } & 26.51919 \\ \text { Mean of Response } & 121.1227 \\ \text { Observations (or Sum Wgts) } & 44\end{array}$

Analysis of Variance

$\begin{array}{lllll}\text { Source } & \text { DF } & \text { Sum of Squares } & \text { Mean Square } & \text { F Ratio } \\ \text { Model } & 4 & 86765.18 & 21691.3 & 30.8436 \\ \text { Error } & 39 & 27427.44 & 703.3 & \text { Prob }>F^{*} \\ \text { C. Total } & 43 & 114192.61 & & <.0001\end{array}$

Lack Of Fit

$\begin{array}{lllll}\text { Source } & \text { DF } & \text { Sum of Squares } & \text { Mean Square } & \text { F Ratio } \\ \text { Lack Of Fit } & 31 & 14179.280 & 457.40 & 0.2762 \\ \text { Pure Error } & 8 & 13248.155 & 1656.02 & \text { Prob }>F^{*} \\ \text { Total Error } & 39 & 27427.435 & & 0.9956 \\ & & & & \text { Max RSq } \\ & & & & 0.8840\end{array}$

$\underline{\text { Parameter Estimates }}$

$\begin{array}{lllll}\text { Term } & \text { Estimate } & \text { Std Error } & \text { t Ratio } & \text { Prob }>|t|^{*} \\ \text { Intercept } & 29.523339 & 19.69735 & 1.50 & 0.1420 \\ \text { TIS } & -13.19305 & 1.899249 & -6.95 & <.0001 \\ \text { TMP } & 6.0132893 & 6.591277 & 0.91 & 0.3672 \\ \text { Vel } & 40.381227 & 4.687911 & 8.61 & <.0001 \\ \text { Filter[0.1 Pall] } & 1.195 & 3.997919 & 0.30 & 0.7666\end{array}$


Table B-4. Statistical Analysis of $0.1 \mu \mathrm{m}$ Pall and Graver Media (continued).

$\underline{\text { Effect Tests }}$

$\begin{array}{llllll}\text { Source } & \text { Nparm } & \text { DF } & \text { Sum of Squares } & \text { F Ratio } & \text { Prob }>F^{*} \\ \text { TIS } & 1 & 1 & 33934.940 & 48.2532 & <.0001 \\ \text { TMP } & 1 & 1 & 585.337 & 0.8323 & 0.3672 \\ \text { Vel } & 1 & 1 & 52182.016 & 74.1994 & <.0001 \\ \text { Filter } & 1 & 1 & 62.833 & 0.0893 & 0.7666\end{array}$

Filter

Least Squares Means Table

Level Least Sq Mean

$\begin{array}{ll}\text { Std Error } & \text { Mean } \\ 5.6539108 & 122.318 \\ 5.6539108 & 119.928\end{array}$

Graver $\quad 119.92773$

* Values less than 0.05 indicate statistically significant effects 
Table B-5. Statistical Analysis of $0.1 \mu \mathrm{m}$ Mott and $0.5 \mu \mathrm{m}$ Mott Media.

Response Flux

Whole Model

$\underline{\text { Summary of Fit }}$

$\begin{array}{ll}\text { RSquare } & 0.708038 \\ \text { RSquare Adj } & 0.678093 \\ \text { Root Mean Square Error } & 23.26767 \\ \text { Mean of Response } & 103.0682 \\ \text { Observations (or Sum Wgts) } & 44\end{array}$

Analysis of Variance

$\begin{array}{lllll}\text { Source } & \text { DF } & \text { Sum of Squares } & \text { Mean Square } & \text { F Ratio } \\ \text { Model } & 4 & 51203.640 & 12800.9 & 23.6448 \\ \text { Error } & 39 & 21114.000 & 541.4 & \text { Prob }>F^{*} \\ \text { C. Total } & 43 & 72317.640 & & <.0001\end{array}$

Lack Of Fit

$\begin{array}{lllll}\text { Source } & \text { DF } & \text { Sum of Squares } & \text { Mean Square } & \text { F Ratio } \\ \text { Lack Of Fit } & 31 & 12165.153 & 392.42 & 0.3508 \\ \text { Pure Error } & 8 & 8948.846 & 1118.61 & \text { Prob }>F^{*} \\ \text { Total Error } & 39 & 21114.000 & & 0.9830 \\ & & & & \text { Max RSq } \\ & & & & 0.8763\end{array}$

$\underline{\text { Parameter Estimates }}$

$\begin{array}{lllll}\text { Term } & \text { Estimate } & \text { Std Error } & \mathrm{t} \text { Ratio } & \text { Prob }>|\mathrm{t}|^{*} \\ \text { Intercept } & 25.594162 & 17.28226 & 1.48 & 0.1467 \\ \text { TIS } & -10.31095 & 1.666382 & -6.19 & <.0001 \\ \text { TMP } & 9.454631 & 5.78312 & 1.63 & 0.1101 \\ \text { Vel } & 30.118288 & 4.113126 & 7.32 & <.0001 \\ \text { Filter[0.1 Mott] } & 0.0927273 & 3.507734 & 0.03 & 0.9790\end{array}$


Table B-5. Statistical Analysis of $0.1 \mu \mathrm{m}$ Mott and $0.5 \mu \mathrm{m}$ Mott Media (continued).

\section{$\underline{\text { Effect Tests }}$}

$\begin{array}{llllll}\text { Source } & \text { Nparm } & \text { DF } & \text { Sum of Squares } & \text { F Ratio } & \text { Prob }>F^{*} \\ \text { TIS } & 1 & 1 & 20727.841 & 38.2867 & <.0001 \\ \text { TMP } & 1 & 1 & 1447.007 & 2.6728 & 0.1101 \\ \text { Vel } & 1 & 1 & 29028.352 & 53.6187 & <.0001 \\ \text { Filter } & 1 & 1 & 0.378 & 0.0007 & 0.9790\end{array}$

Filter

Least Squares Means Table

Level Least Sq Mean

$\begin{array}{ll}\text { Std Error } & \text { Mean } \\ 4.9606846 & 103.161 \\ 4.9606846 & 102.975\end{array}$

0.1 Mott 103.16091

$4.9606846-102.975$

* Values less than 0.05 indicate statistically significant effects 
Table B-6. Statistical Data for tests performed at $35^{\circ} \mathrm{C}$.

Response Flux@35C

Whole Model

$\underline{\text { Summary of Fit }}$

RSquare $\quad 0.820902$

RSquare Adj $\quad 0.805977$

Root Mean Square Error $\quad 0.013713$

Mean of Response $\quad 0.082455$

Observations (or Sum Wgts) 66

Analysis of Variance

$\begin{array}{lllll}\text { Source } & \text { DF } & \text { Sum of Squares } & \text { Mean Square } & \text { F Ratio } \\ \text { Model } & 5 & 0.05171385 & 0.010343 & 55.0025 \\ \text { Error } & 60 & 0.01128251 & 0.000188 & \text { Prob }>\text { F }^{*} \\ \text { C. Total } & 65 & 0.06299636 & & <.0001\end{array}$

$\underline{\text { Lack Of Fit }}$

$\begin{array}{lllll}\text { Source } & \text { DF } & \text { Sum of Squares } & \text { Mean Square } & \text { F Ratio } \\ \text { Lack Of Fit } & 48 & 0.00946784 & 0.000197 & 1.3044 \\ \text { Pure Error } & 12 & 0.00181467 & 0.000151 & \text { Prob }>F^{*} \\ \text { Total Error } & 60 & 0.01128251 & & 0.3196 \\ & & & & \text { Max RSq } \\ & & & & 0.9712\end{array}$

$\underline{\text { Parameter Estimates }}$

$\begin{array}{lllll}\text { Term } & \text { Estimate } & \text { Std Error } & \mathrm{t} \text { Ratio } & \text { Prob }>|\mathrm{t}|^{*} \\ \text { Intercept } & 0.0464884 & 0.008329 & 5.58 & <.0001 \\ \text { Filter[0.1 Mott] } & -0.008275 & 0.002387 & -3.47 & 0.0010 \\ \text { Filter[0.1 Pall] } & 0.0056855 & 0.002387 & 2.38 & 0.0204 \\ \text { TIS } & -0.010435 & 0.00076 & -13.72 & <.0001 \\ \text { TMP } & 0.0004765 & 0.000192 & 2.48 & 0.0159 \\ \text { Axial Velocity } & 0.005067 & 0.000614 & 8.26 & <.0001\end{array}$


Table B-6. Statistical Data for tests performed at $35^{\circ} \mathrm{C}$ (continued).

$\underline{\text { Effect Tests }}$

$\begin{array}{llllll}\text { Source } & \text { Nparm } & \text { DF } & \text { Sum of Squares } & \text { F Ratio } & \text { Prob }>F^{*} \\ \text { Filter } & 2 & 2 & 0.00236471 & 6.2877 & 0.0033 \\ \text { TIS } & 1 & 1 & 0.03542117 & 188.3685 & <.0001 \\ \text { TMP } & 1 & 1 & 0.00115782 & 6.1573 & 0.0159 \\ \text { Axial Velocity } & 1 & 1 & 0.01282412 & 68.1982 & <.0001\end{array}$

Filter

Least Squares Means Table

$\begin{array}{llll}\text { Level } & \text { Least Sq Mean } & \text { Std Error } & \text { Mean } \\ 0.1 \text { Mott } & 0.07417999 & 0.00292363 & 0.074318 \\ \text { 0.1 Pall } & 0.08814002 & 0.00292378 & 0.087864 \\ \text { Graver } & 0.08504363 & 0.00292363 & 0.085182\end{array}$

* Values less than 0.05 indicate statistically significant effects 
Appendix C

\section{Variation Testing}

Water Flux 


\section{Appendix C}

\section{Variation Testing \\ Water Flux}

Table C-1. Pristine Water Flux (Graver $0.07 \mu \mathrm{m})$.

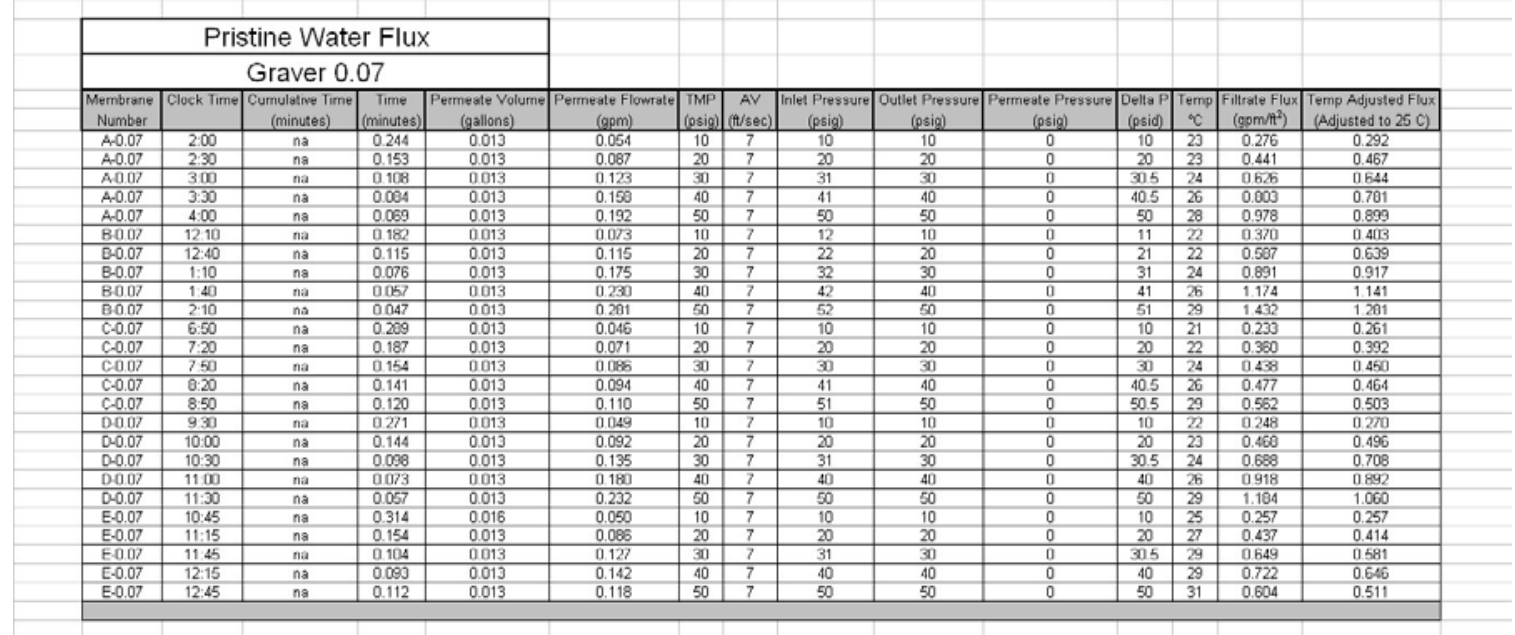

Table C-2. Conditioning Sequence (Graver $0.07 \mu \mathrm{m}$ ).

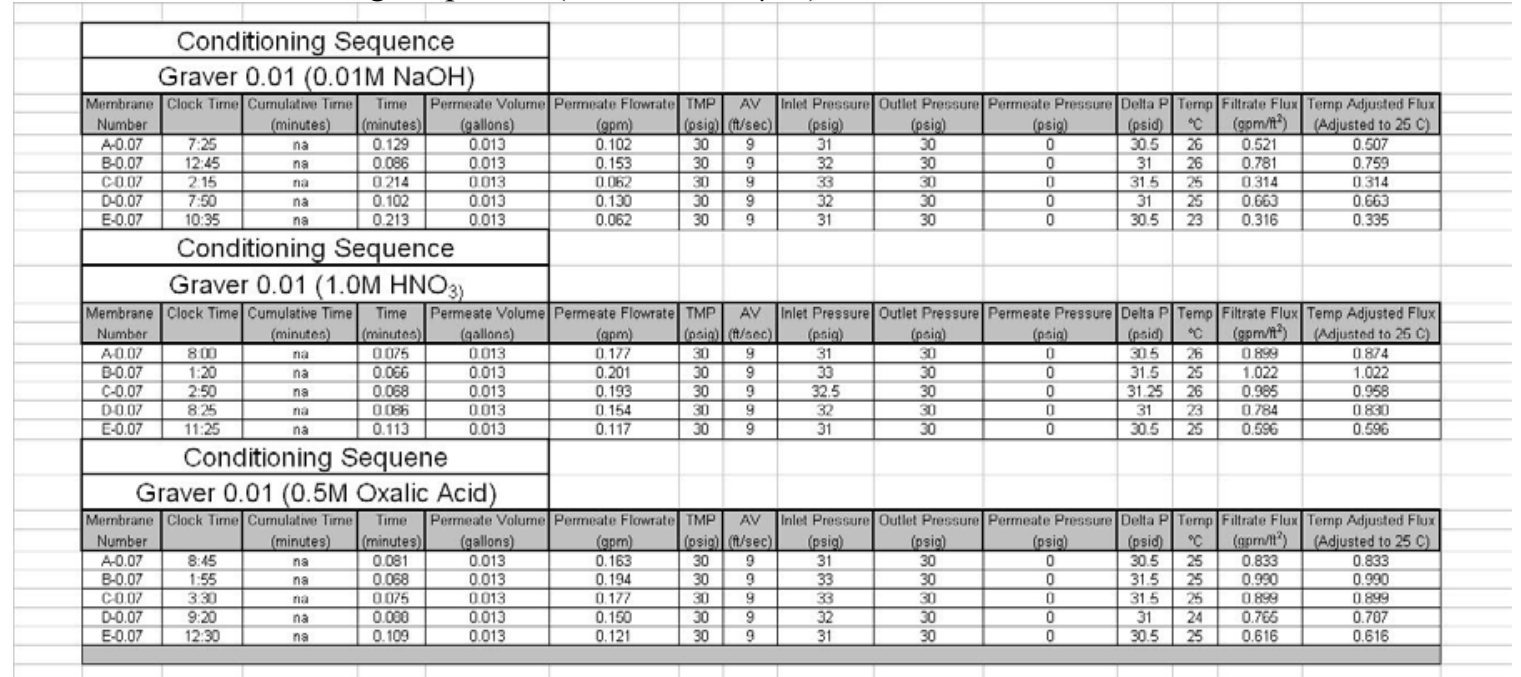


Table C-3. Repeated Water Flux (Graver $0.07 \mu \mathrm{m}$ ).

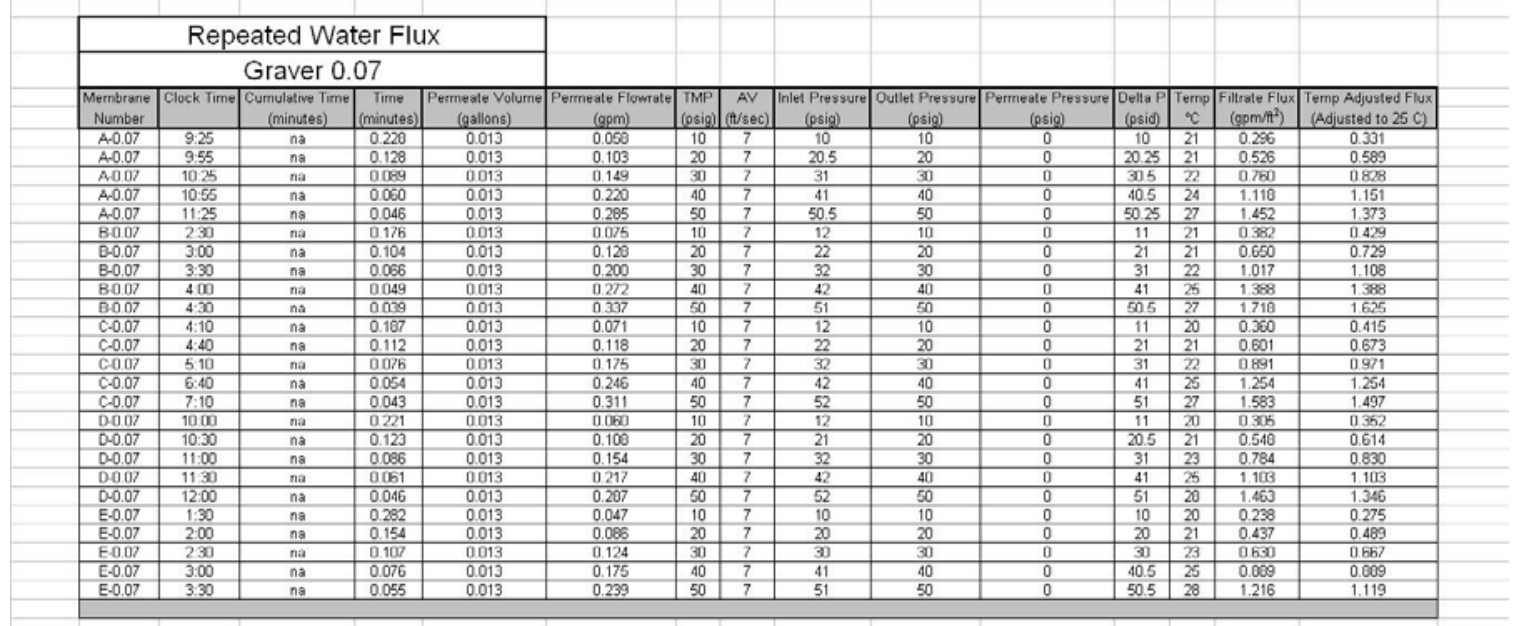

Table C-4. Final Water Flux (Graver $0.07 \mu \mathrm{m})$.

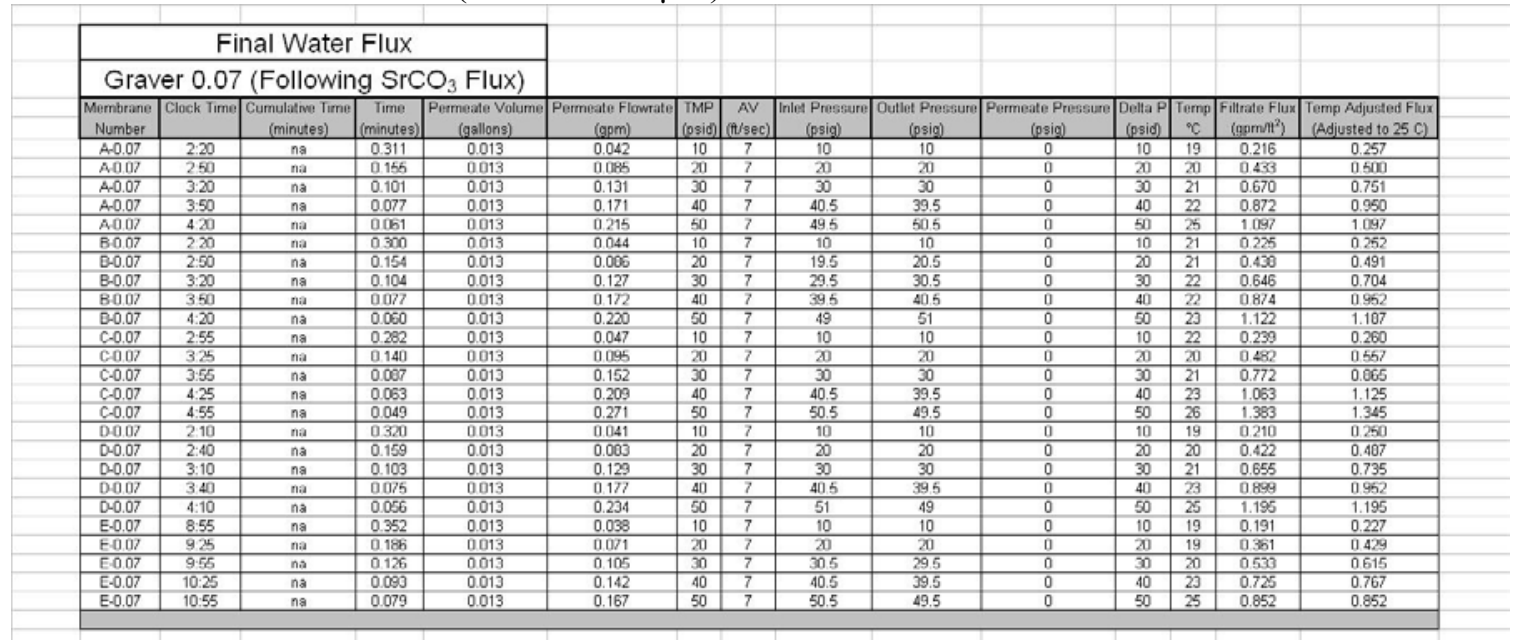

Table C-5. Pristine Water Flux (Mott $0.1 \mu \mathrm{m}$ ).

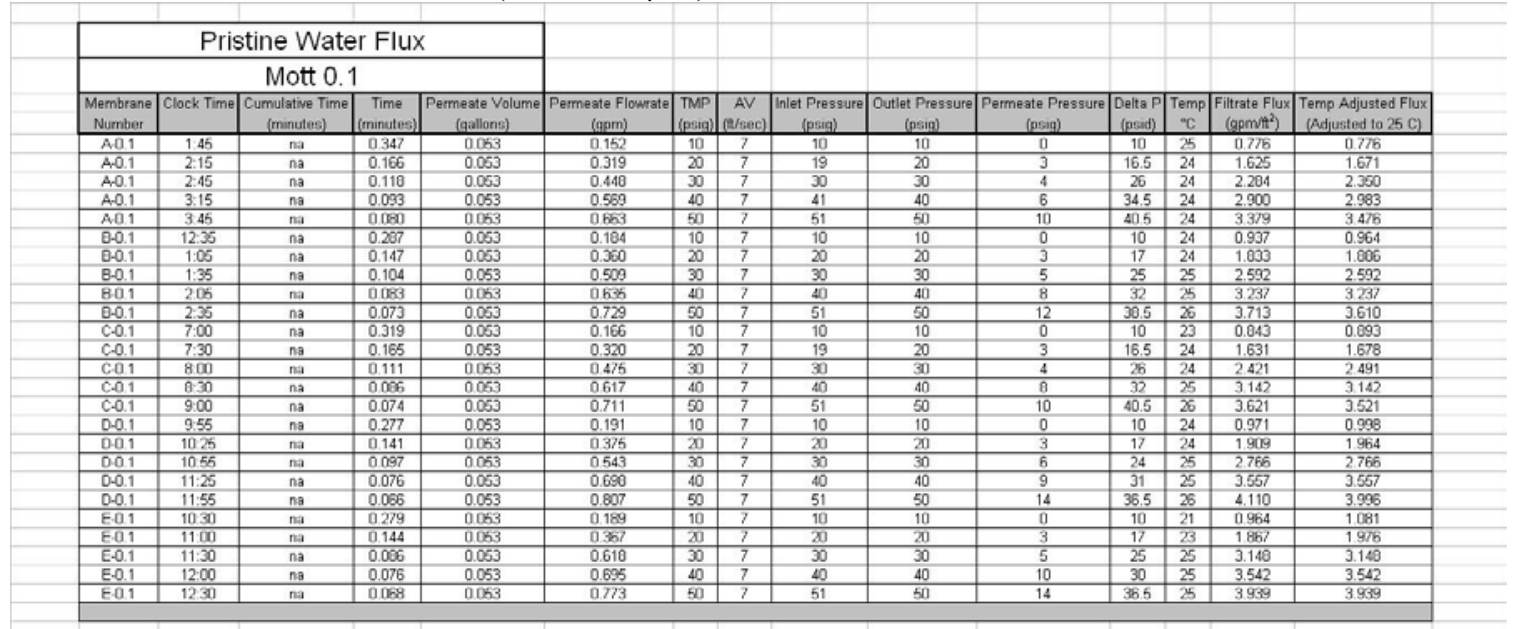


Table C-6. Conditioning Sequence (Mott $0.1 \mu \mathrm{m}$ ).

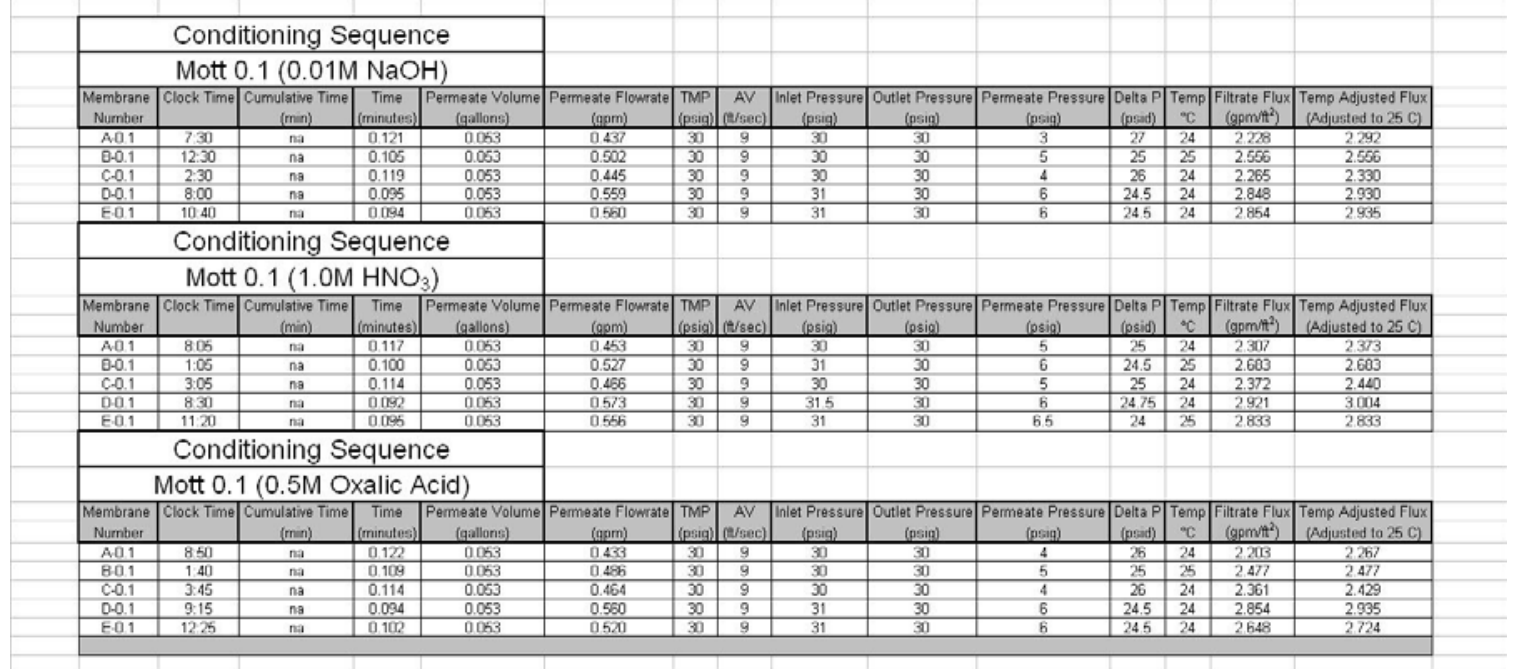

Table C-7. Repeated Water Flux (Mott $0.1 \mu \mathrm{m}$ ).

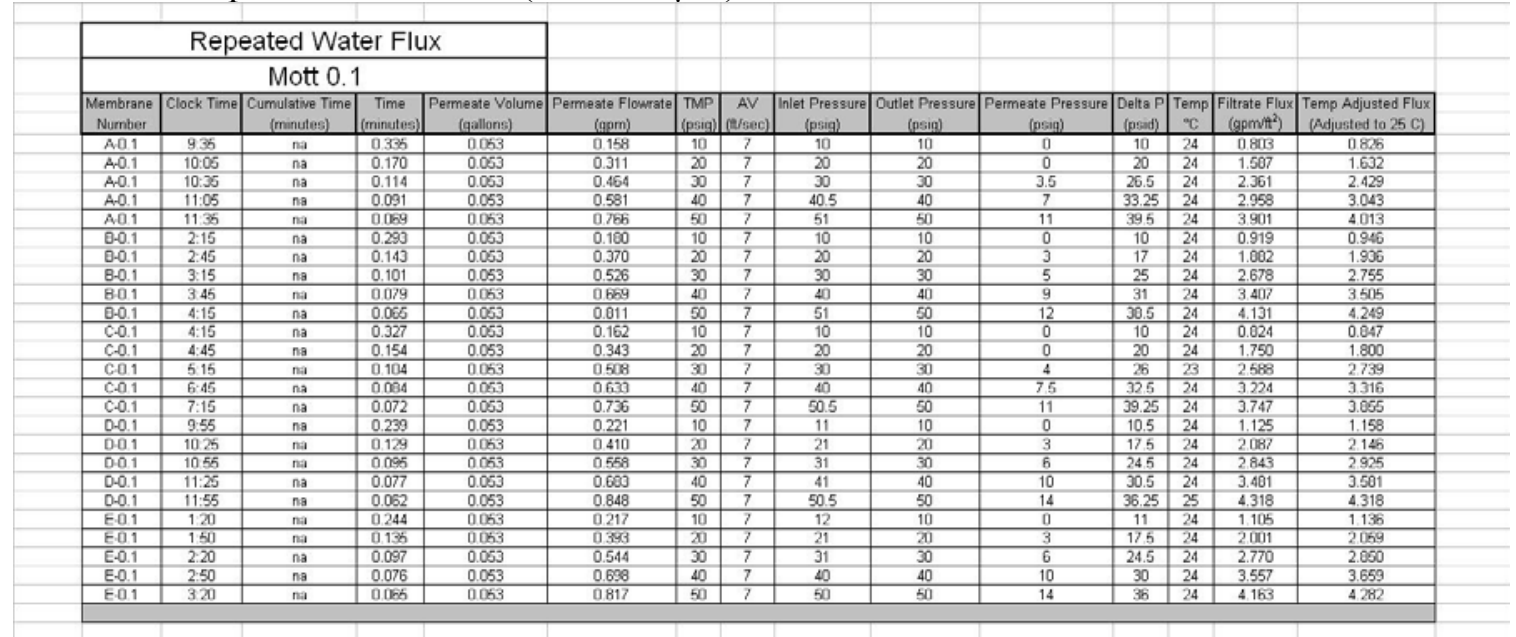

Table C-8. Final Water Flux (Mott $0.1 \mu \mathrm{m}$ ).

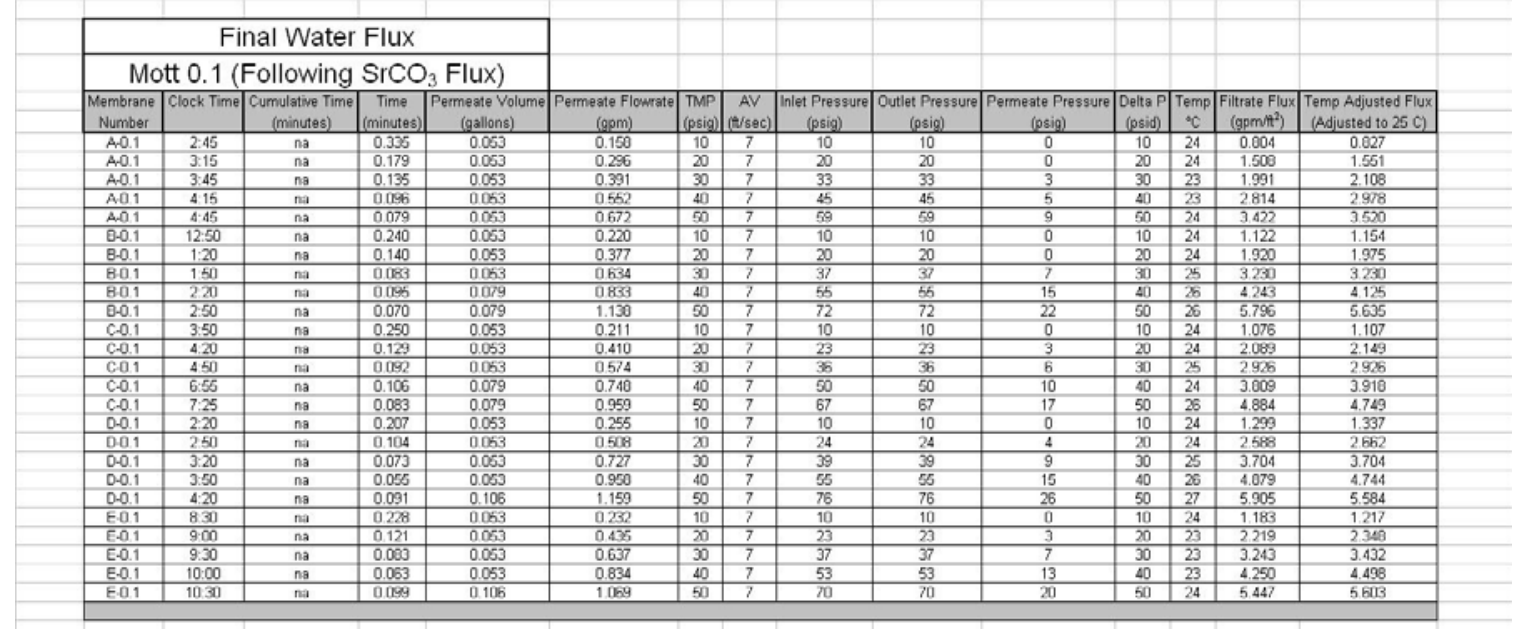


Table C-9. Pristine Water Flux (Mott $0.5 \mu \mathrm{m}$ ).

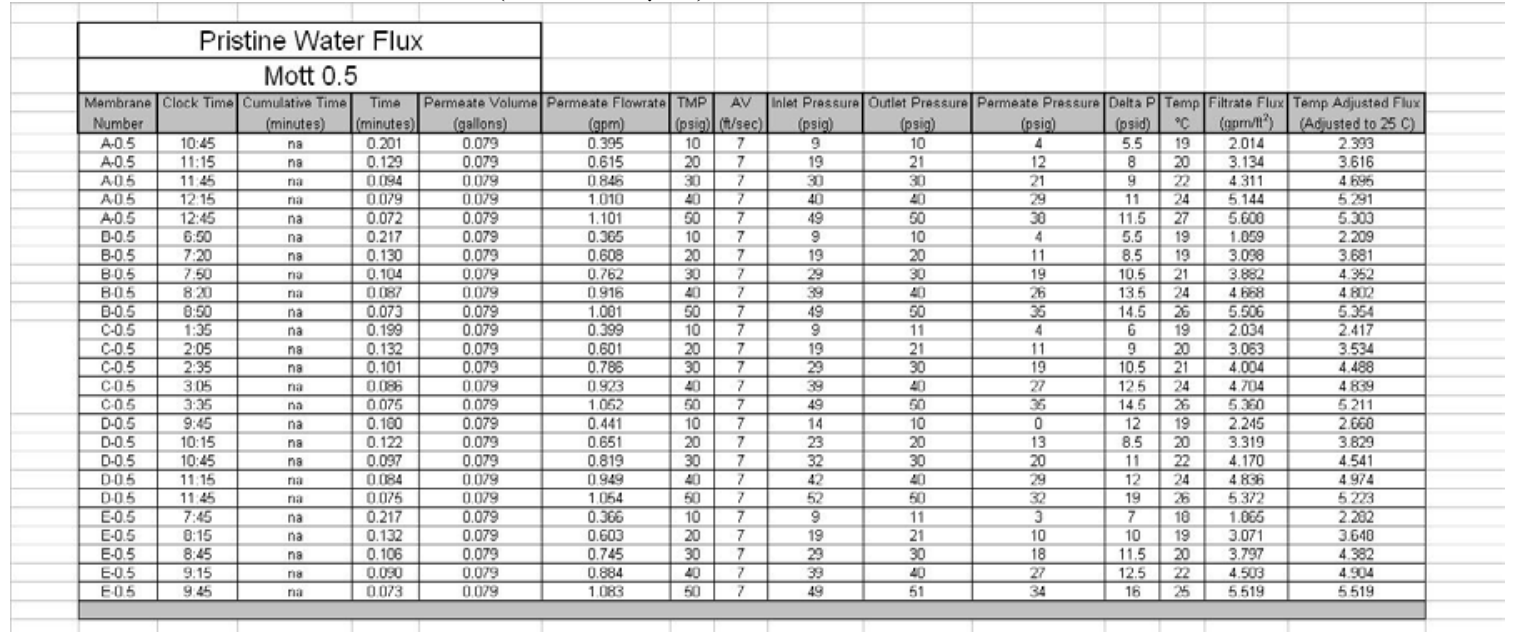

Table C-10. Conditioning Sequence (Mott $0.5 \mu \mathrm{m}$ ).

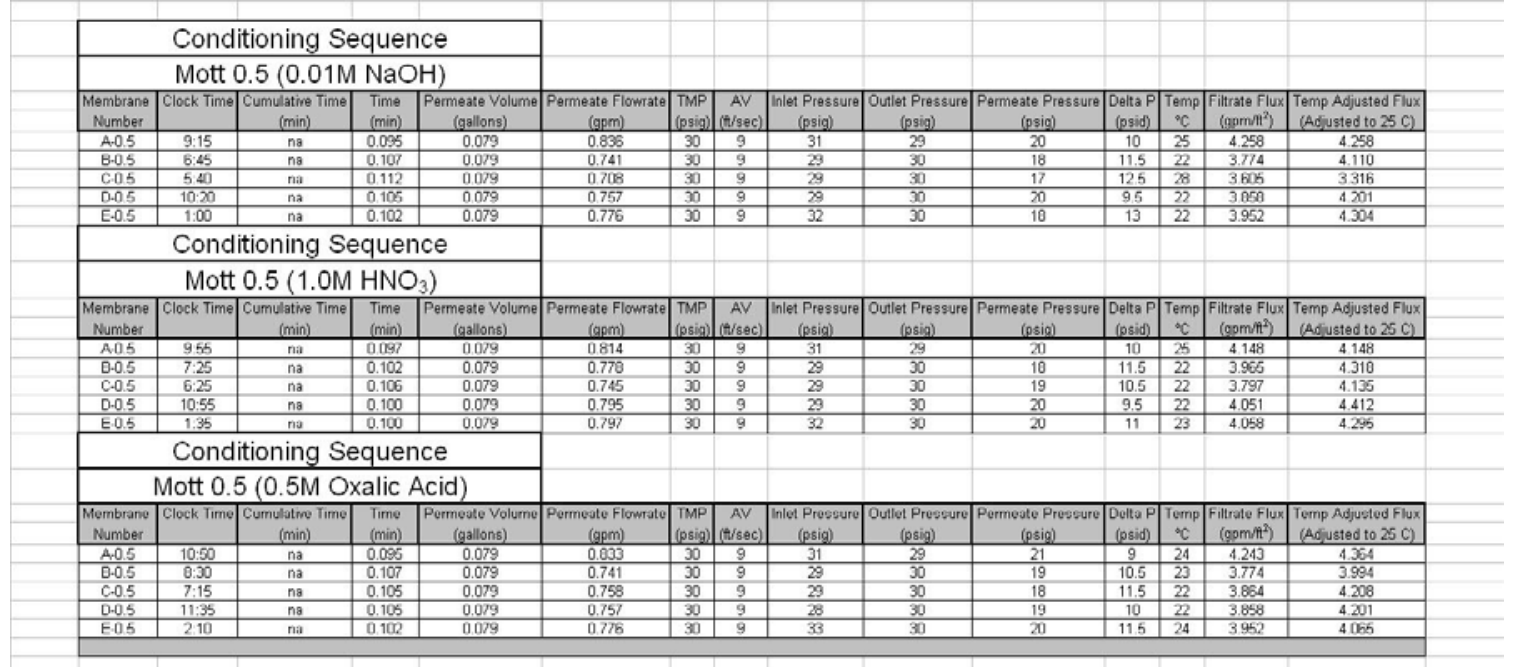

Table C-11. Repeated Water Flux (Mott $0.5 \mu \mathrm{m}$ ).

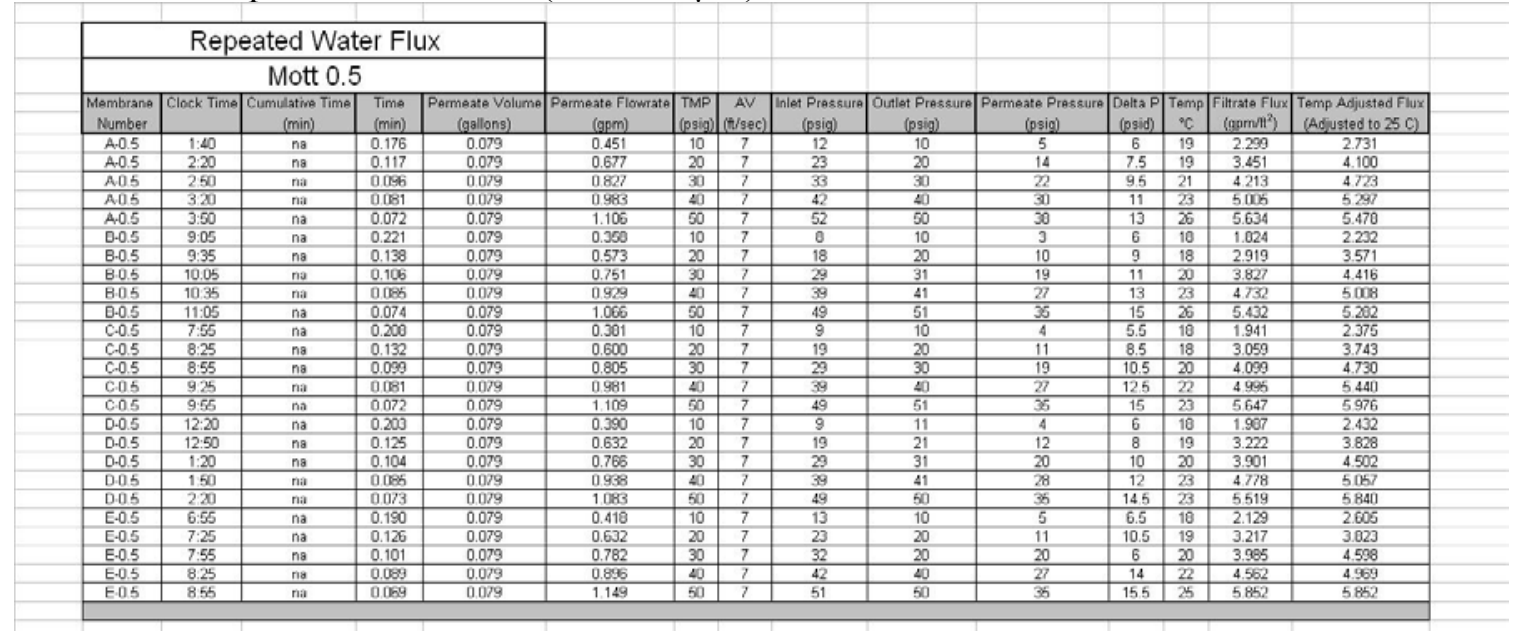


Table C-12. Final Water Flux (Mott $0.5 \mu \mathrm{m}$ ).

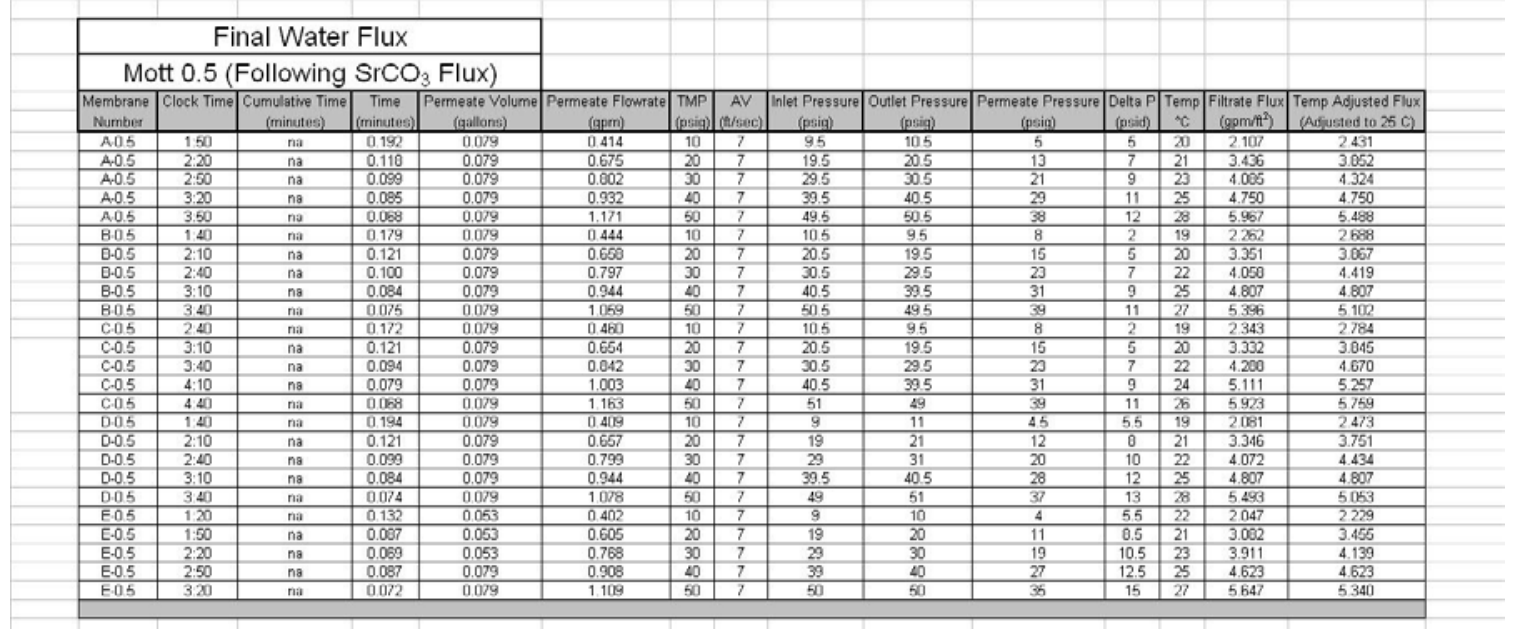

Table C-13. Pristine Water Flux (Pall $0.1 \mu \mathrm{m})$.

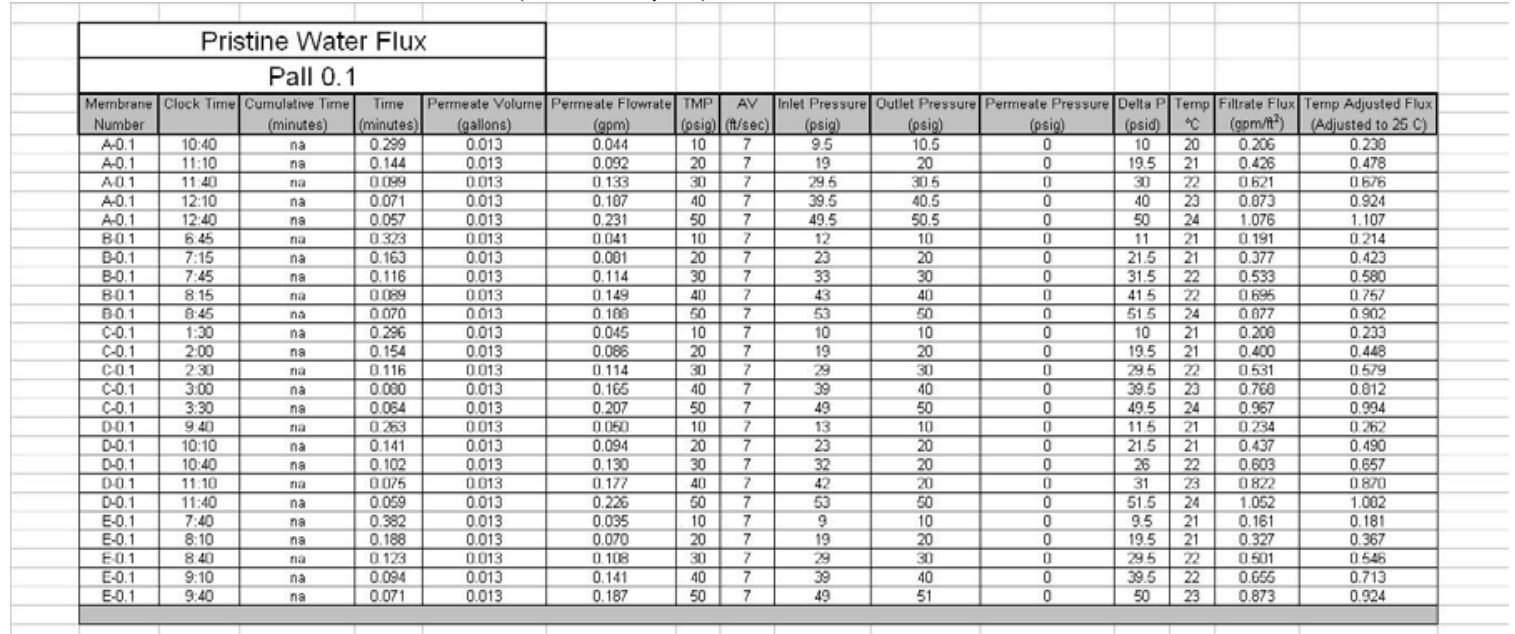

Table C-14. Conditioning Sequence (Pall $0.1 \mu \mathrm{m})$.

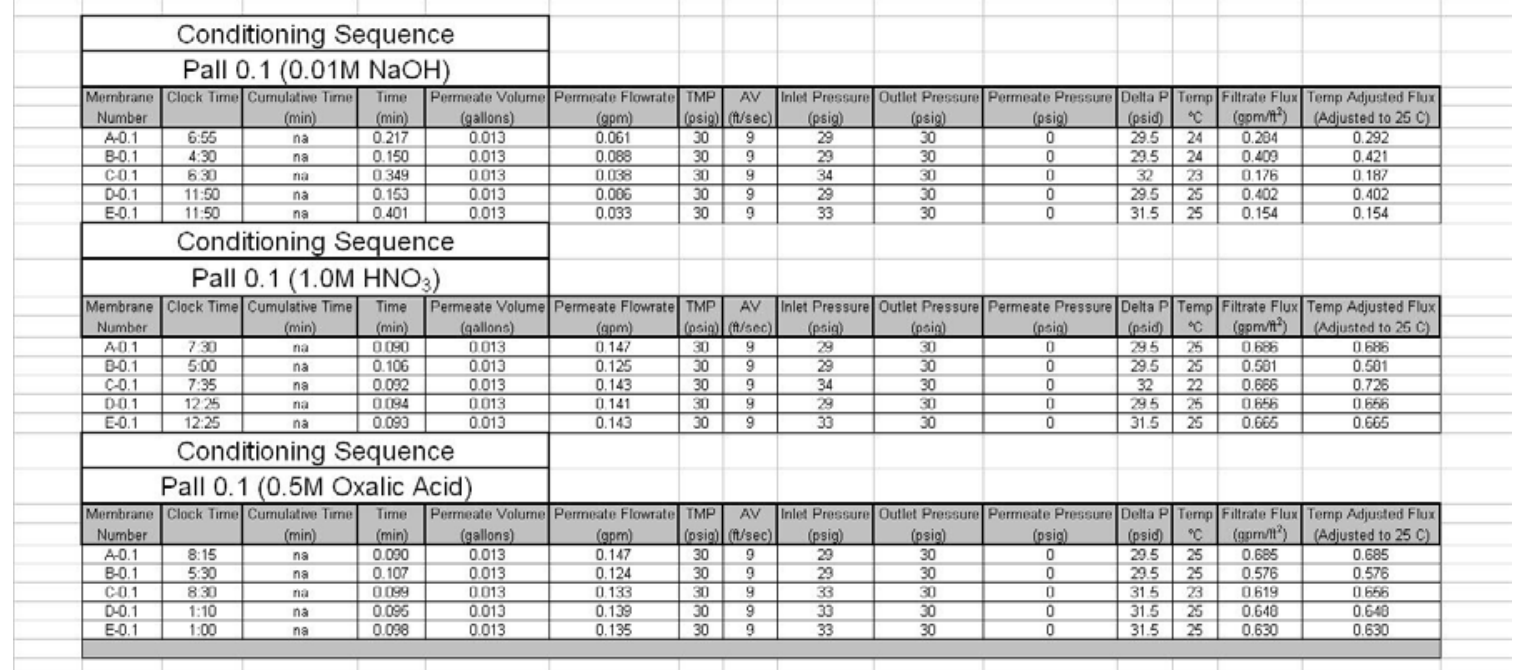


Table C-15. Repeated Water Flux (Pall $0.1 \mu \mathrm{m})$.

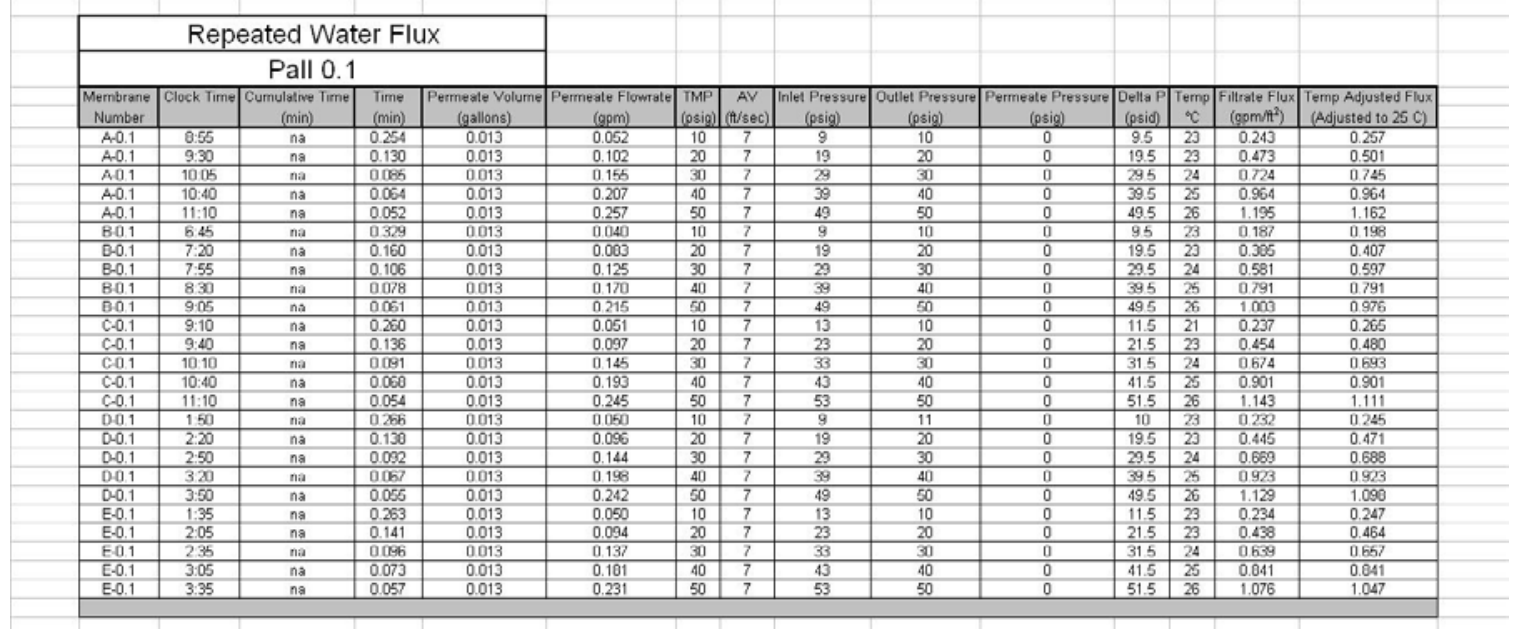

Table C-16. Final Water Flux (Pall $0.1 \mu \mathrm{m})$.

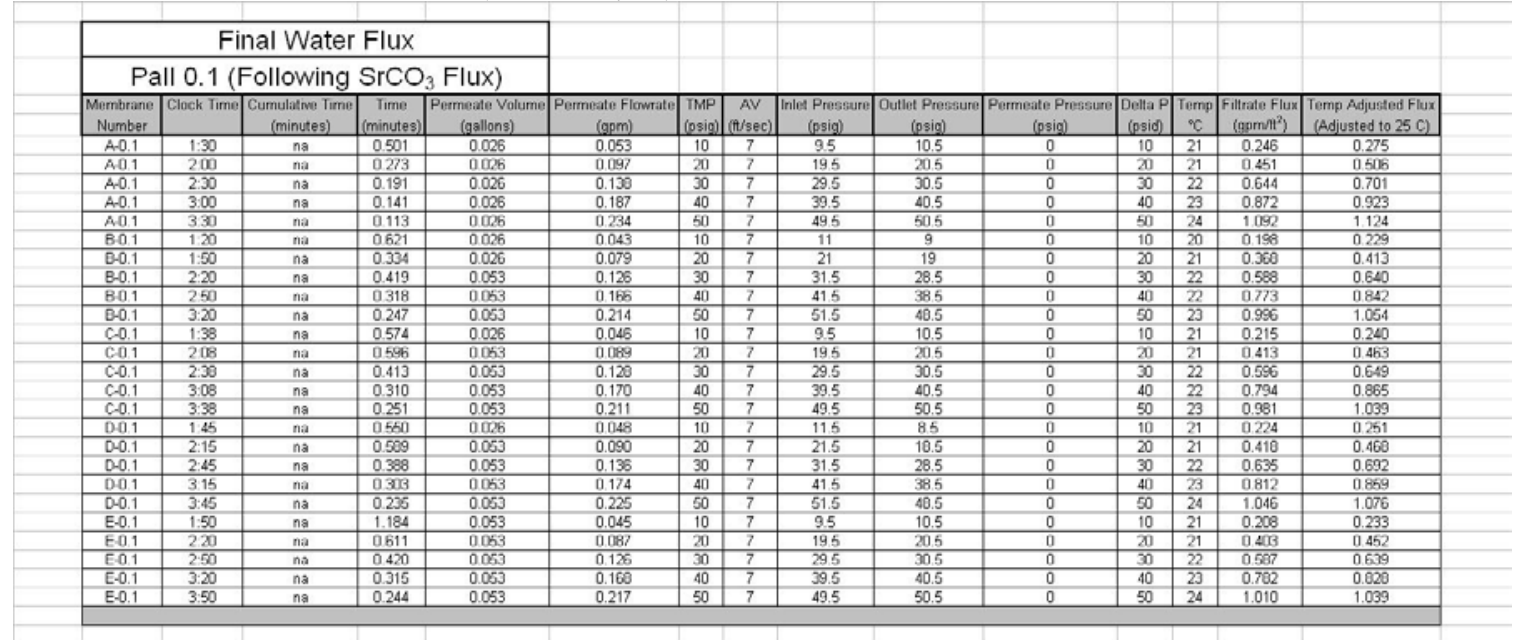

Table C-17. Pristine Water Flux (Pall $0.8 \mu \mathrm{m})$.

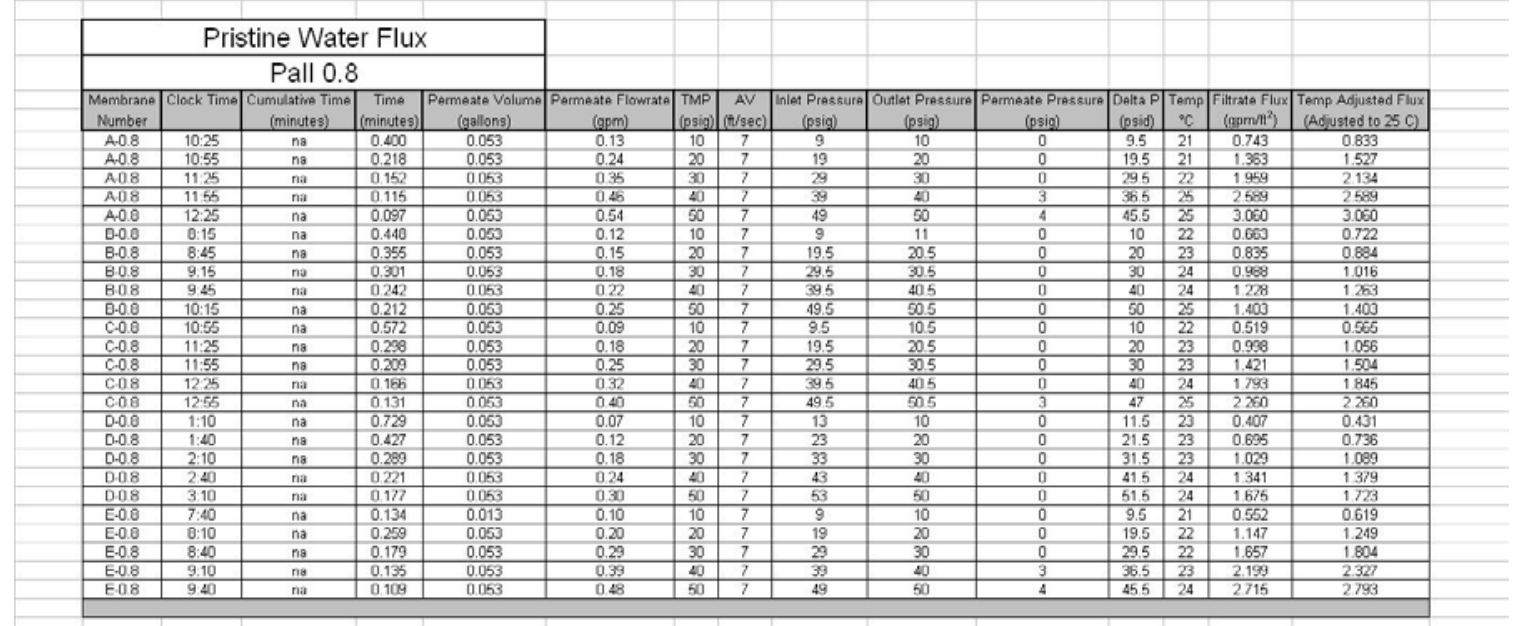


Table C-18. Conditioning Sequence (Pall $0.8 \mu \mathrm{m}$ ).

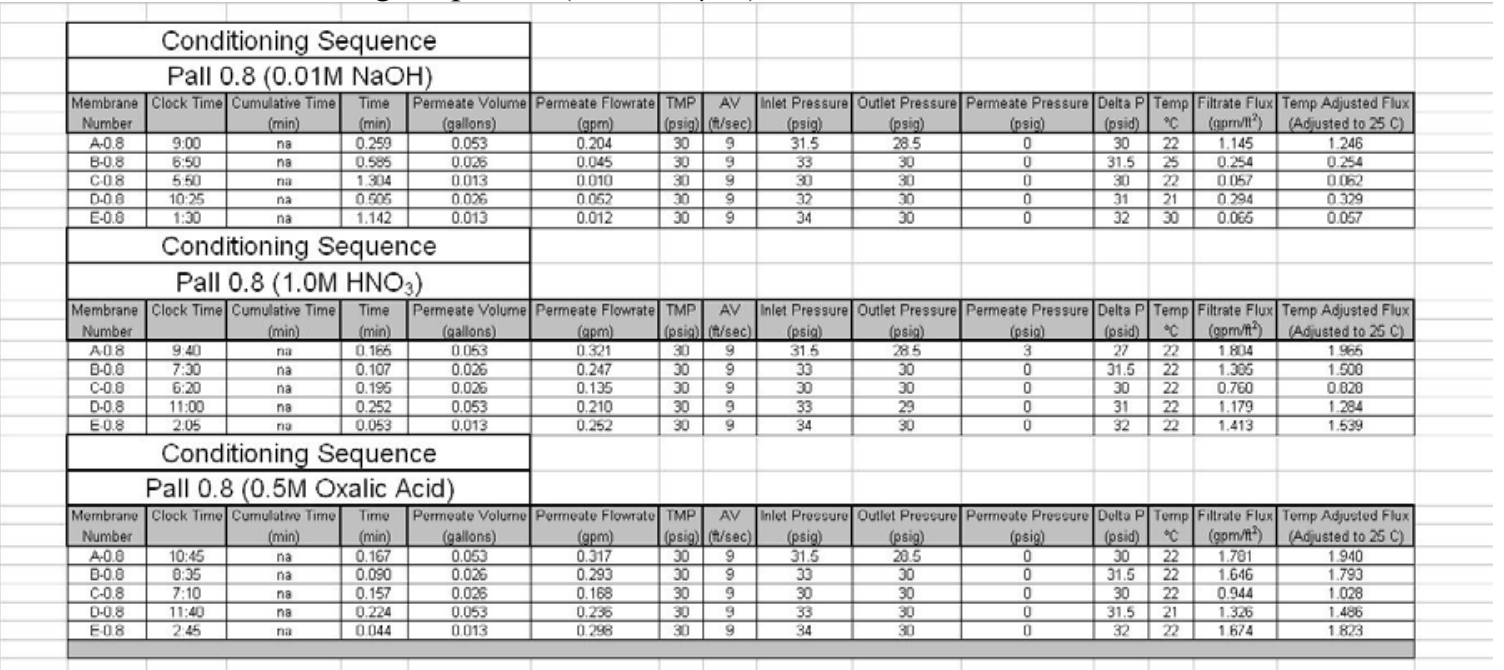

Table C-19. Repeated Water Flux (Pall $0.8 \mu \mathrm{m}$ ).

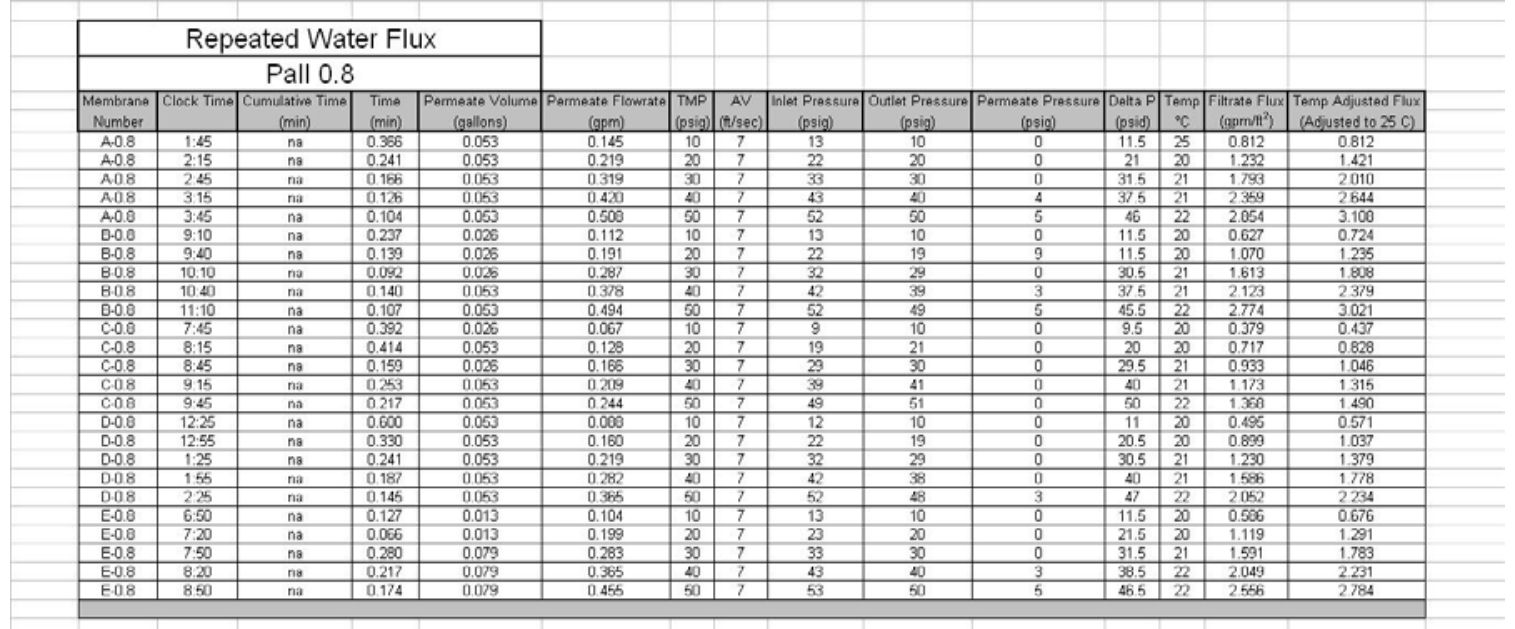

Table C-20. Final Water Flux (Pall $0.8 \mu \mathrm{m}$ ).

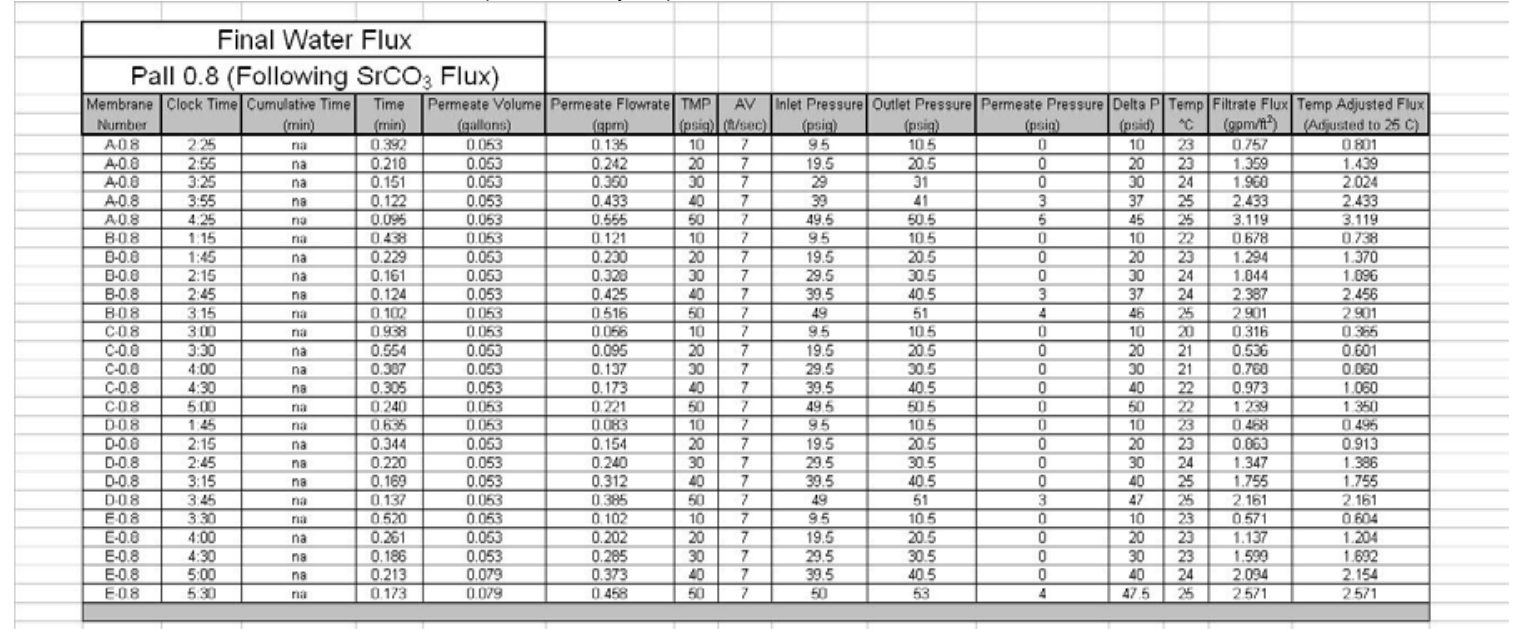


Table C-21. Pristine Water Flux (GKN $0.1 \mu \mathrm{m})$.

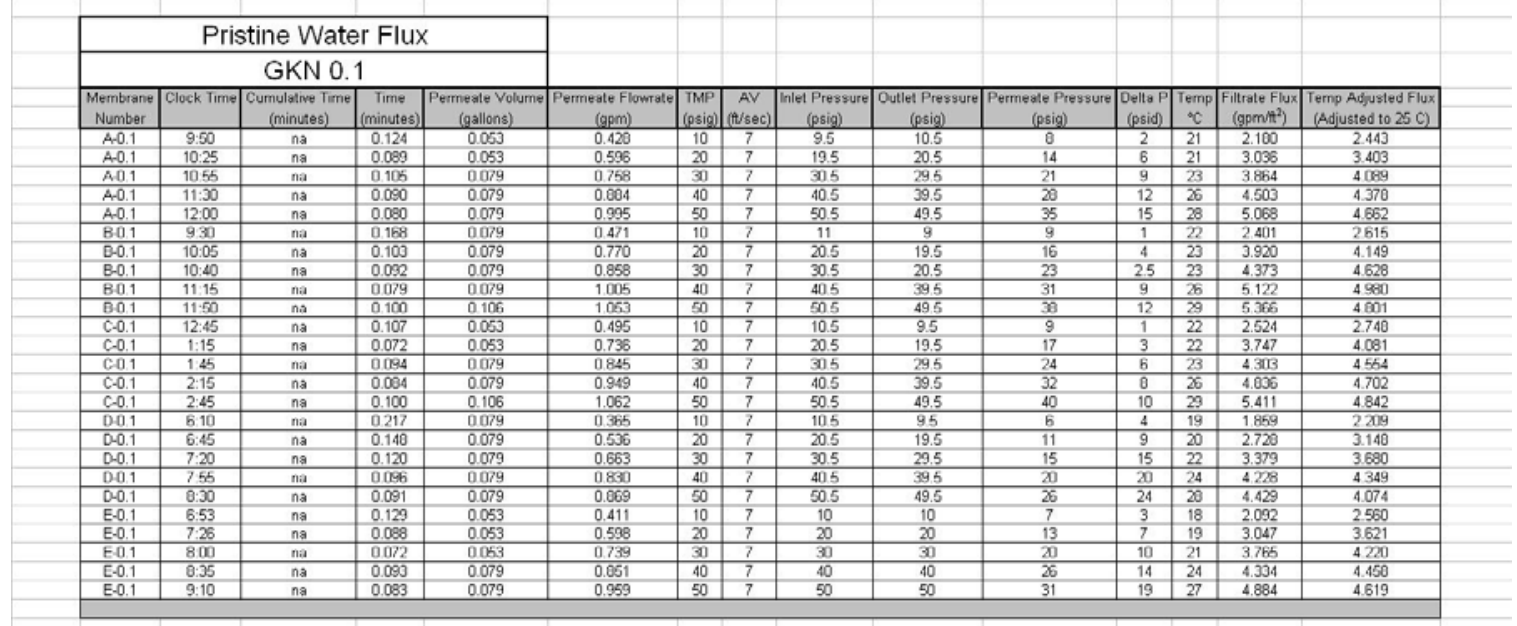

Table C-22. Conditioning Sequence (GKN $0.1 \mu \mathrm{m}$ ).

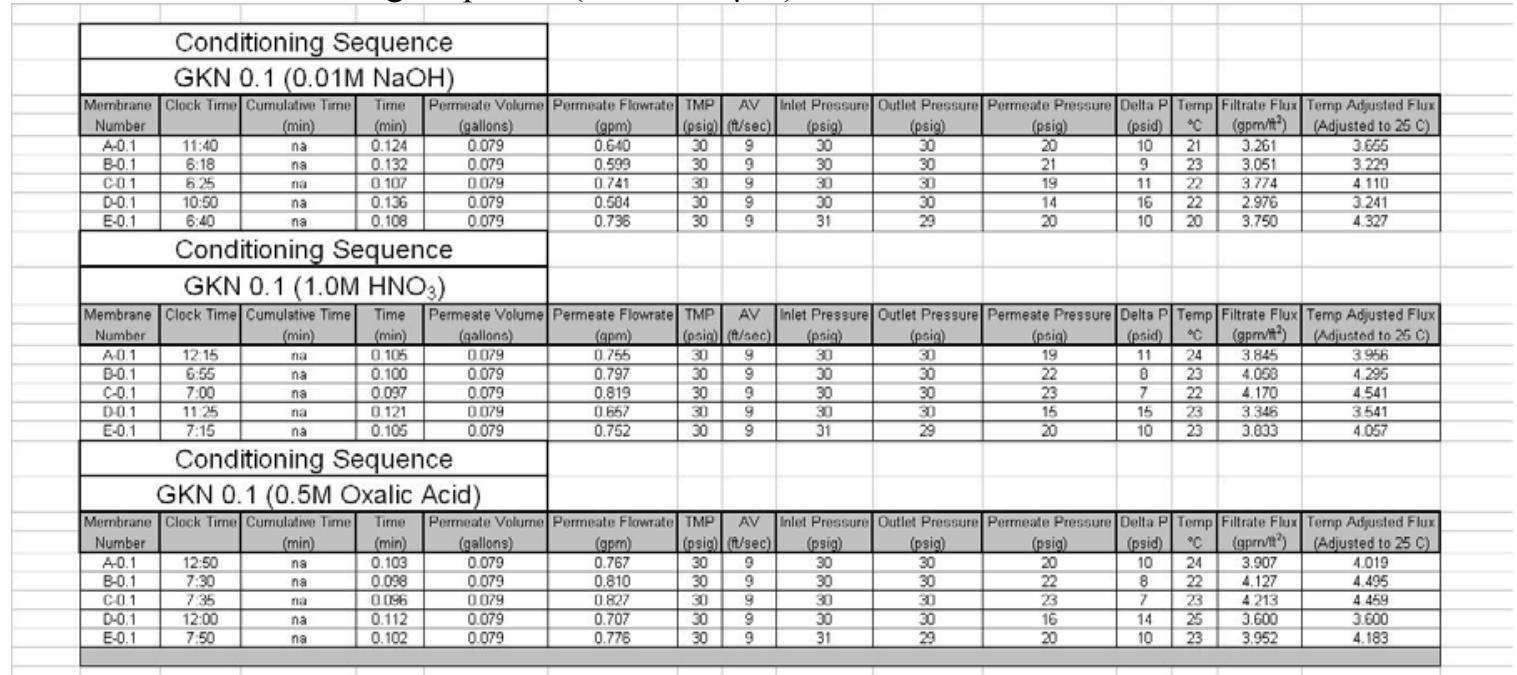

Table C-23. Repeated Water Flux (GKN $0.1 \mu \mathrm{m})$.

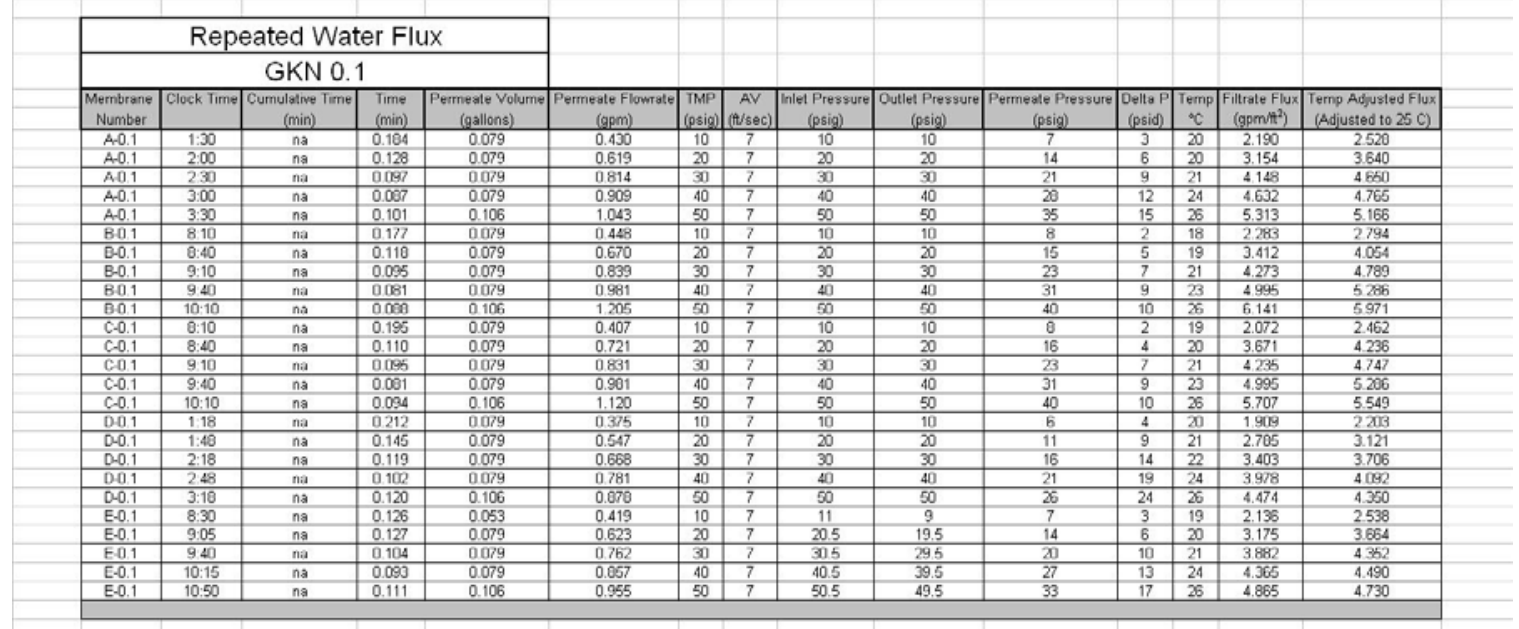


Table C-24. Final Water Flux (GKN $0.1 \mu \mathrm{m})$.

\begin{tabular}{|c|c|c|c|c|c|c|c|c|c|c|c|c|c|c|c|}
\hline 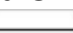 & 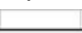 & 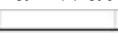 & 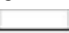 & & & 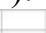 & 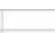 & & & & & - & & & \\
\hline \multicolumn{5}{|c|}{ Final Water Flux } & & & & & & & & & & & \\
\hline \multicolumn{5}{|c|}{ GKN 0.1 (Following $\mathrm{SrCO}_{3}$ Flux) } & & & & & & & & & & & \\
\hline Membrane & Clock Time & Cumulahive Time & Time & Pesmeate Volume & Permeate Flowrate & TMP & AV & Inlet Pressure & Outlet Pressure & Permeate Pressure & Della P & Temp & Filtrate Flux & Temp Adigusted Flux & \\
\hline Number & 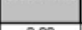 & \begin{tabular}{|l|} 
(minutes) \\
\end{tabular} & (minutes) & \begin{tabular}{|l|} 
(gallons) \\
\end{tabular} & \begin{tabular}{|l|l}
$(\mathrm{gpm})$ \\
0.40
\end{tabular} & (osige) & $(t / \mathrm{sec})$ & (psig) & \begin{tabular}{|l|} 
(psig) \\
10
\end{tabular} & \begin{tabular}{|c|} 
(psig) \\
7
\end{tabular} & (psid) & & (gpm/12) & (Adjusted to 25C) & \\
\hline $\mathrm{A}-0.1$ & $2: 00$ & na & 0.180 & 0.079 & 0.440 & 10 & 7 & $\frac{10}{x}$ & $\begin{array}{l}10 \\
x \\
\end{array}$ & 7 & 3 & 19 & 2.241 & 2.663 & \\
\hline A0.1 & $\frac{230}{300}$ & na & 0.127 & 0079 & 0623 & 20 & 7 & $\frac{20}{30}$ & $\frac{20}{n}$ & $\frac{14}{21}$ & 6 & 19 & 3.175 & 3772 & \\
\hline$A_{0} 0.1$ & $3: 00$ & $n a$ & 0.102 & 0.079 & 0.701 & 30 & 7 & 30 & 30 & 21 & 9 & 21 & 3.970 & 4.459 & \\
\hline$A 0.1$ & $3: 30$ & na & 0.083 & 0.079 & 0.955 & 40 & 7 & 40 & 40 & 27 & 13 & 23 & 4.865 & 5.148 & \\
\hline A01 & 400 & na & 00173 & 0.079 & 1081 & 50 & 7 & 50 & 50 & 36 & 15 & 26 & 5506 & 5364 & \\
\hline B01 & 1235 & na & 0189 & 0079 & 0420 & 10 & 7 & 10 & 10 & 8 & 2 & 19 & 2138 & 2541 & \\
\hline $0-0.1$ & 1.05 & na & 0.121 & 0,079 & 0,653 & 20 & 7 & 20 & 20 & 15 & 5 & 20 & 3.351 & 3057 & \\
\hline B-0.1 & $1: 35$ & na & 0.102 & 0.079 & 0.776 & 30 & 7 & 30 & 30 & 23 & 7 & 22 & 3.952 & 4304 & \\
\hline B.1 & 205 & na & 0 (1) & 00779 & 0991 & 40 & 7 & 40 & 40 & $\frac{5}{31}$ & $\frac{1}{9}$ & $\frac{24}{23}$ & $\frac{1.32}{5047}$ & 5341 & \\
\hline 0.0 .1 & 2.35 & na & 0.072 & 0.079 & 1.109 & 50 & 7 & 50 & 50 & $\frac{31}{89}$ & $\frac{3}{11}$ & $\frac{1}{26}$ & $\frac{3.377}{5.647}$ & $\frac{3.441}{5,491}$ & \\
\hline 60.1 & 12.55 & na & 0.176 & 0.079 & 0.449 & 10 & 7 & 10 & 10 & 7 & 3 & 19 & 2.2907 & 2721 & \\
\hline C.1 & 1.25 & na & 0118 & 01789 & $06 \times 2$ & $x$ & 7 & 20 & $x$ & 16 & 4 & 20 & 3422 & 3948 & \\
\hline $\mathrm{C}-0.1$ & $1: 55$ & $n a$ & 0.091 & 0.079 & 0.871 & 30 & 7 & 30 & 30 & 23 & 7 & 22 & 4.437 & 4.032 & \\
\hline C. 0.1 & $2: 25$ & ng & 0.083 & 0.079 & 0.955 & 40 & 7 & 40 & 40 & 31 & 9 & 24 & 4.865 & 5004 & \\
\hline$C=0.1$ & 2.55 & ng & 0.073 & 0.079 & 1.006 & 50 & 7 & 50 & 50 & 40 & 10 & 26 & 5.0007 & 5378 & \\
\hline 001 & 1250 & na & 0224 & 01079 & 0335 & 10 & 7 & 10 & 10 & 6 & 4 & 18 & 1807 & 2211 & \\
\hline 0.01 & 1.20 & na & 0.146 & 0079 & 0.544 & 20 & 7 & 20 & 20 & 11 & 9 & 19 & 27772 & 3293 & \\
\hline 0.0 .1 & 1.50 & nล & 0.125 & 0.079 & 0.636 & 30 & 7 & 30 & 30 & 16 & 14 & 21 & 3.239 & 3.630 & \\
\hline 00.1 & 220 & na & 0.105 & 0079 & 0.757 & 40 & 7 & 40 & 40 & 21 & 19 & 23 & 3858 & 4083 & \\
\hline 0.0 .1 & $2: 50$ & na & 0,0022 & 0.079 & 0.863 & 50 & 7 & 50 & 50 & 26 & 24 & 25 & 4,397 & 4.397 & \\
\hline$E-0.1$ & $2: 20$ & $n g$ & 0.182 & 0.079 & 0.436 & 10 & 7 & 10 & 10 & 8 & 2 & 19 & 2.223 & 2641 & \\
\hline E-01 & 250 & na & 0128 & 00779 & 0.621 & 20 & 7 & 20 & 20 & 14 & 6 & 19 & 3163 & 3758 & \\
\hline$E-01$ & 320 & na & 0100 & 0.079 & 0790 & 30 & 7 & 30 & 30 & 20 & 10 & 20 & 4024 & 4644 & \\
\hline$E-0.1$ & 3.50 & $\mathrm{na}$ & 0.034 & 0.079 & 0.949 & 40 & 7 & 40 & 40 & 27 & 13 & 23 & 4.836 & 5.110 & \\
\hline$E-0.1$ & $4: 20$ & กล & 0.077 & 0.079 & 1.027 & 50 & 7 & 50 & 50 & 33 & 17 & 25 & 5.232 & 5.232 & \\
\hline
\end{tabular}


Appendix D

\section{Variation Testing \\ $\mathrm{SrCO}_{3}$ Flux}


Appendix D

\section{Variation Testing \\ $\mathrm{SrCO}_{3}$ Flux}

Table D-1. Strontium Carbonate Flux (Graver 0.07 $\mu \mathrm{m}$ ).

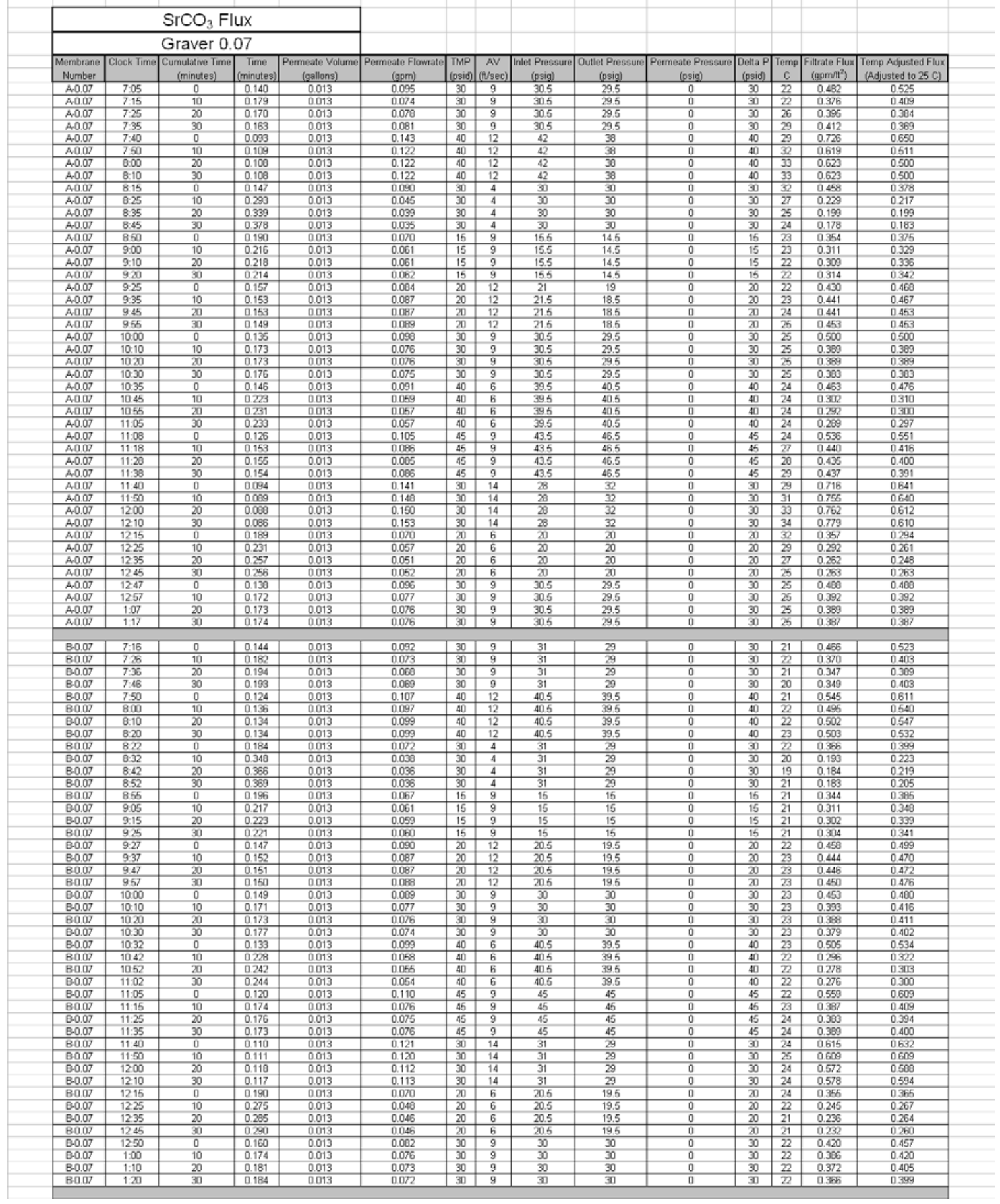


Table D-1. Strontium Carbonate Flux-Graver $0.07 \mu \mathrm{m}$ (continued).

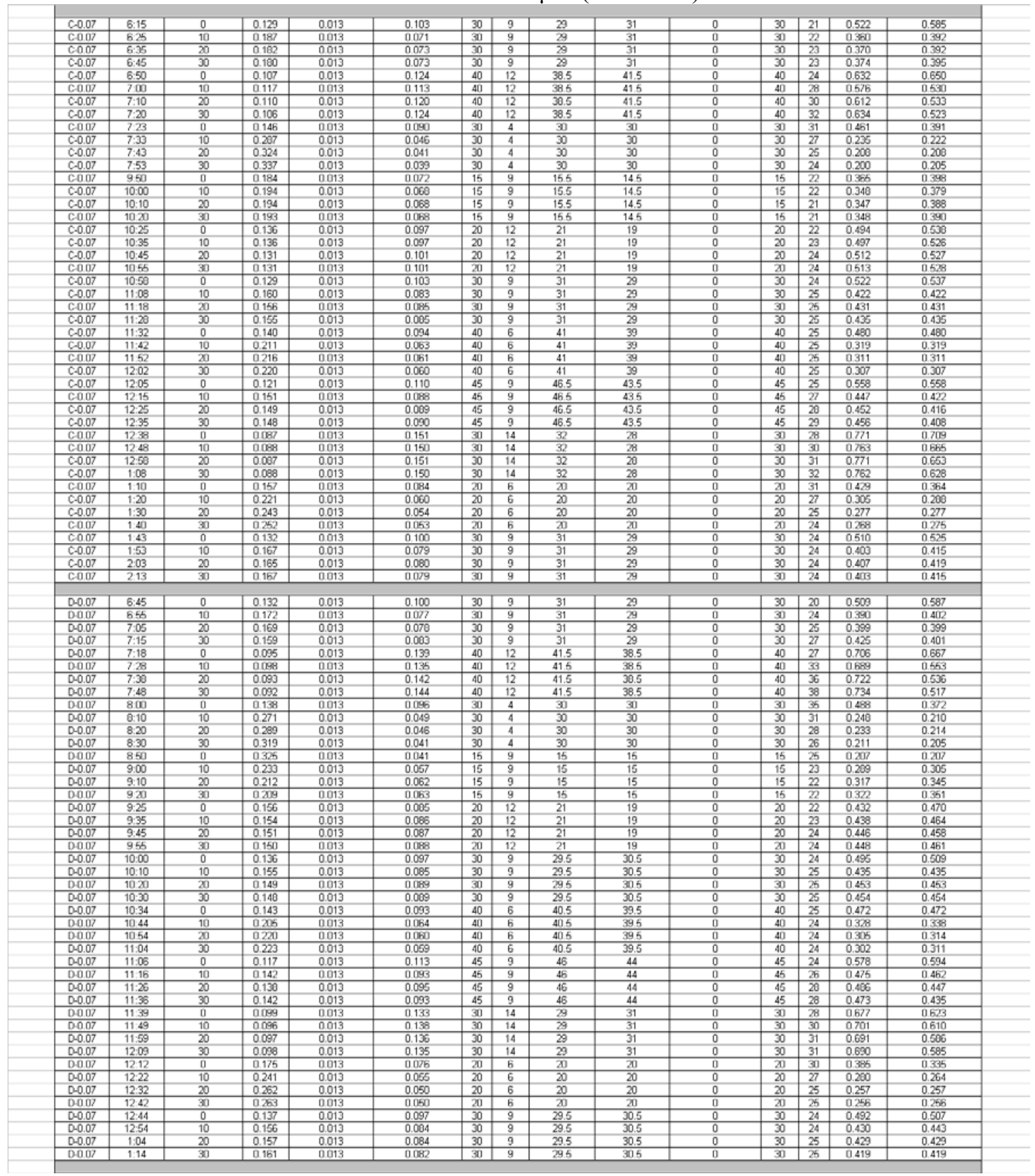


Table D-1. Strontium Carbonate Flux-Graver $0.07 \mu \mathrm{m}$ (continued).

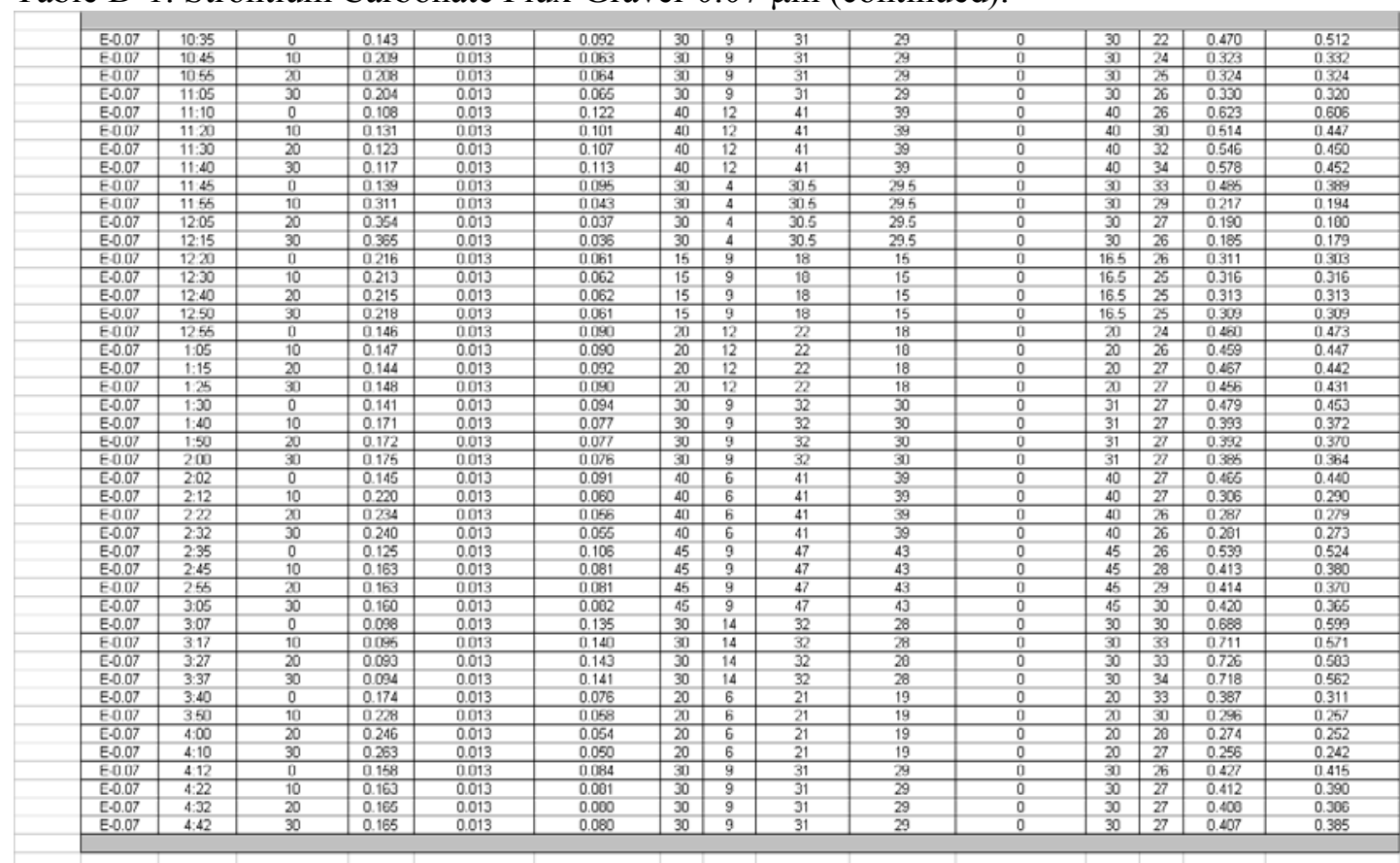


Table D-2. Strontium Carbonate Flux (Mott $0.1 \mu \mathrm{m}$ ).

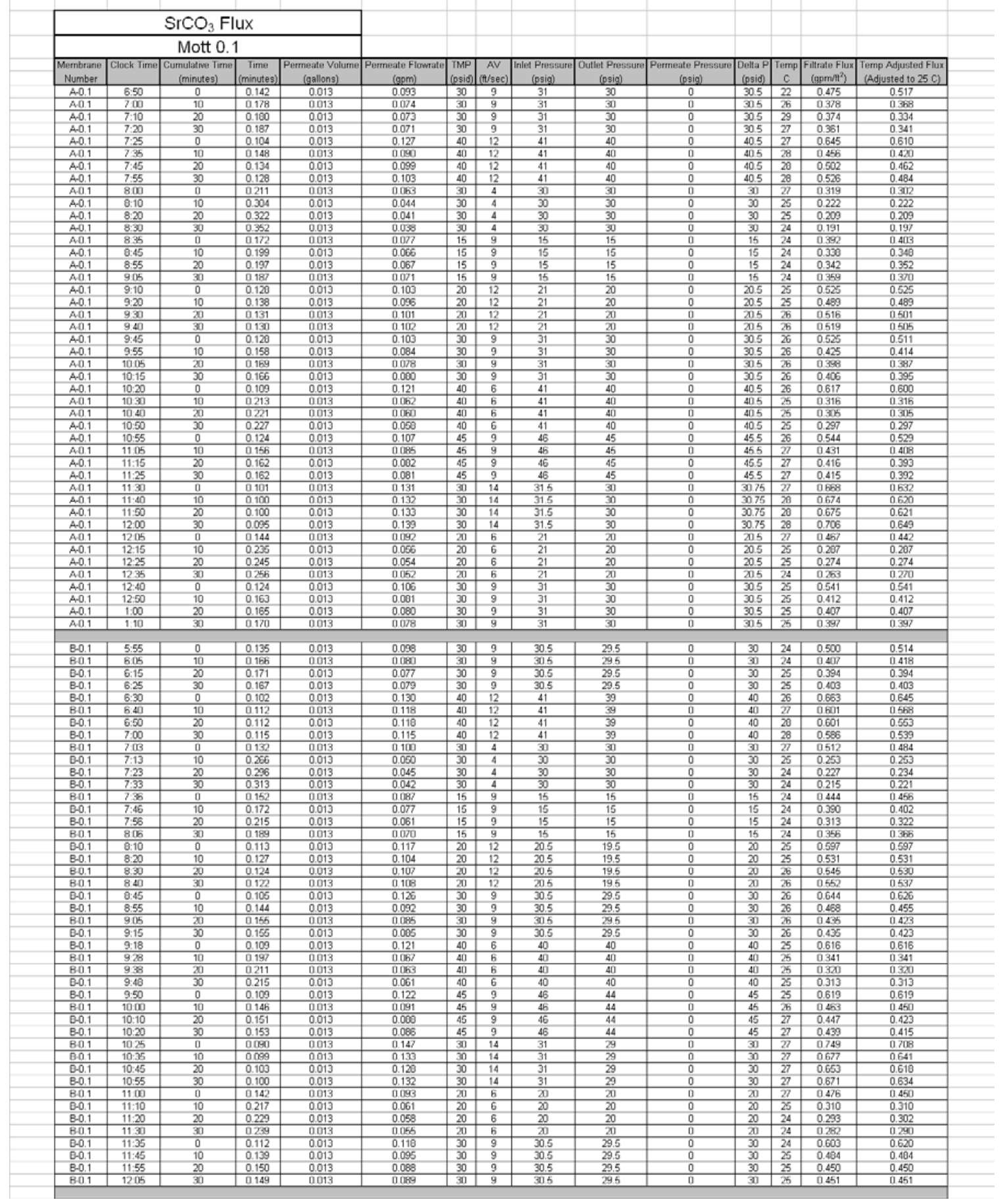


Table D-2. Strontium Carbonate Flux-Mott $0.1 \mu \mathrm{m}$ (continued).

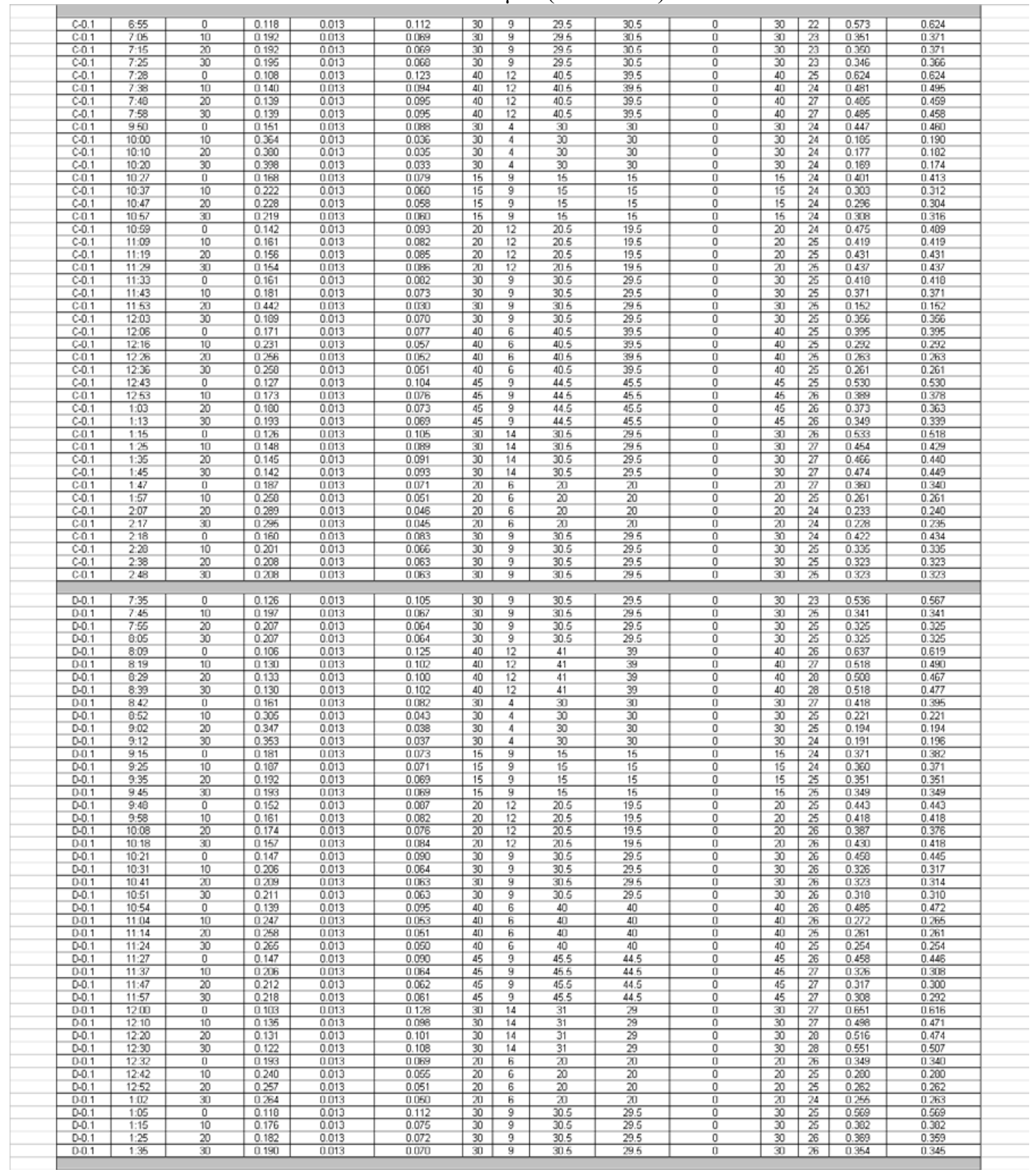


Table D-2. Strontium Carbonate Flux-Mott $0.1 \mu \mathrm{m}$ (continued).

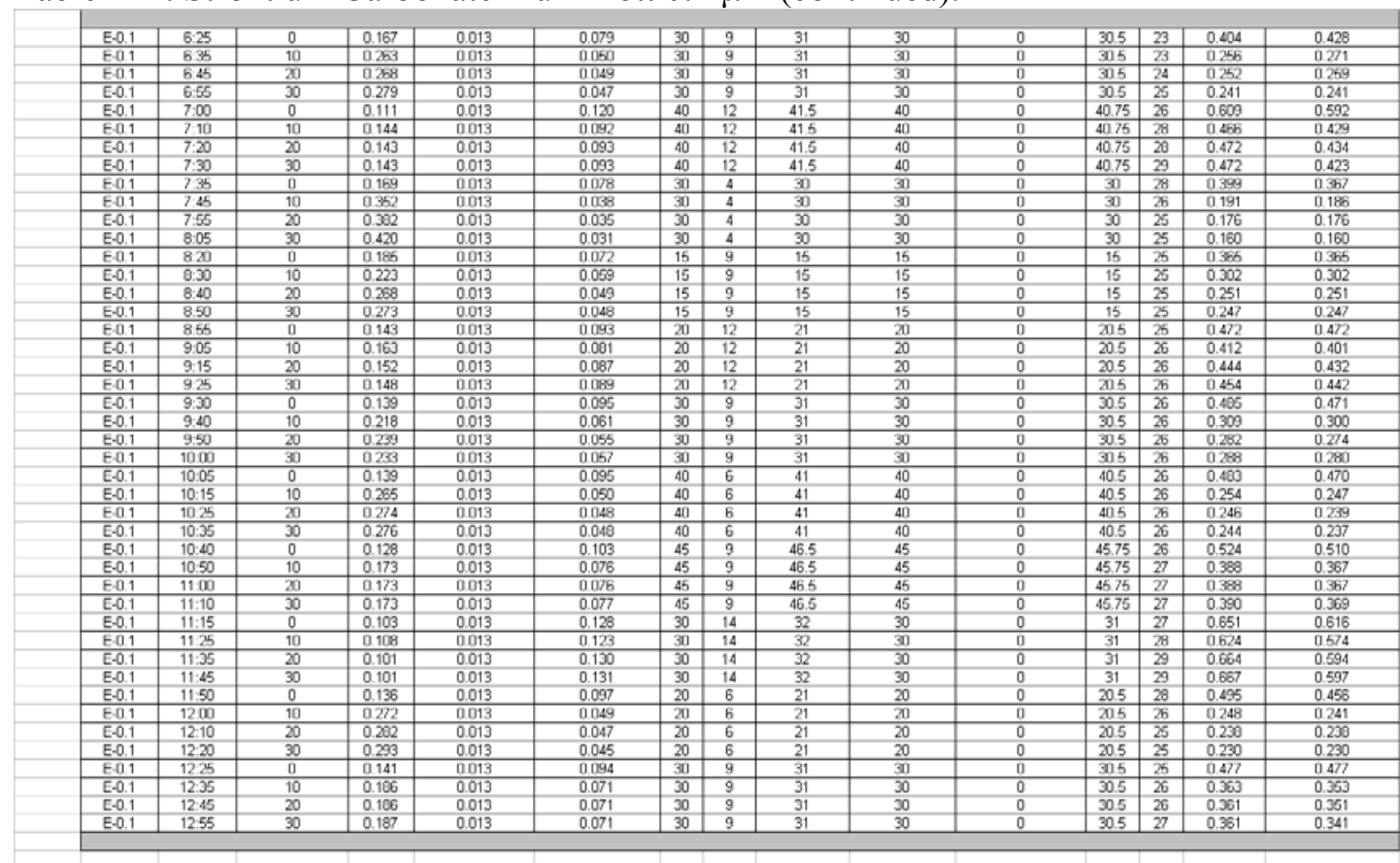


Table D-3. Strontium Carbonate Flux (Mott $0.5 \mu \mathrm{m}$ ).

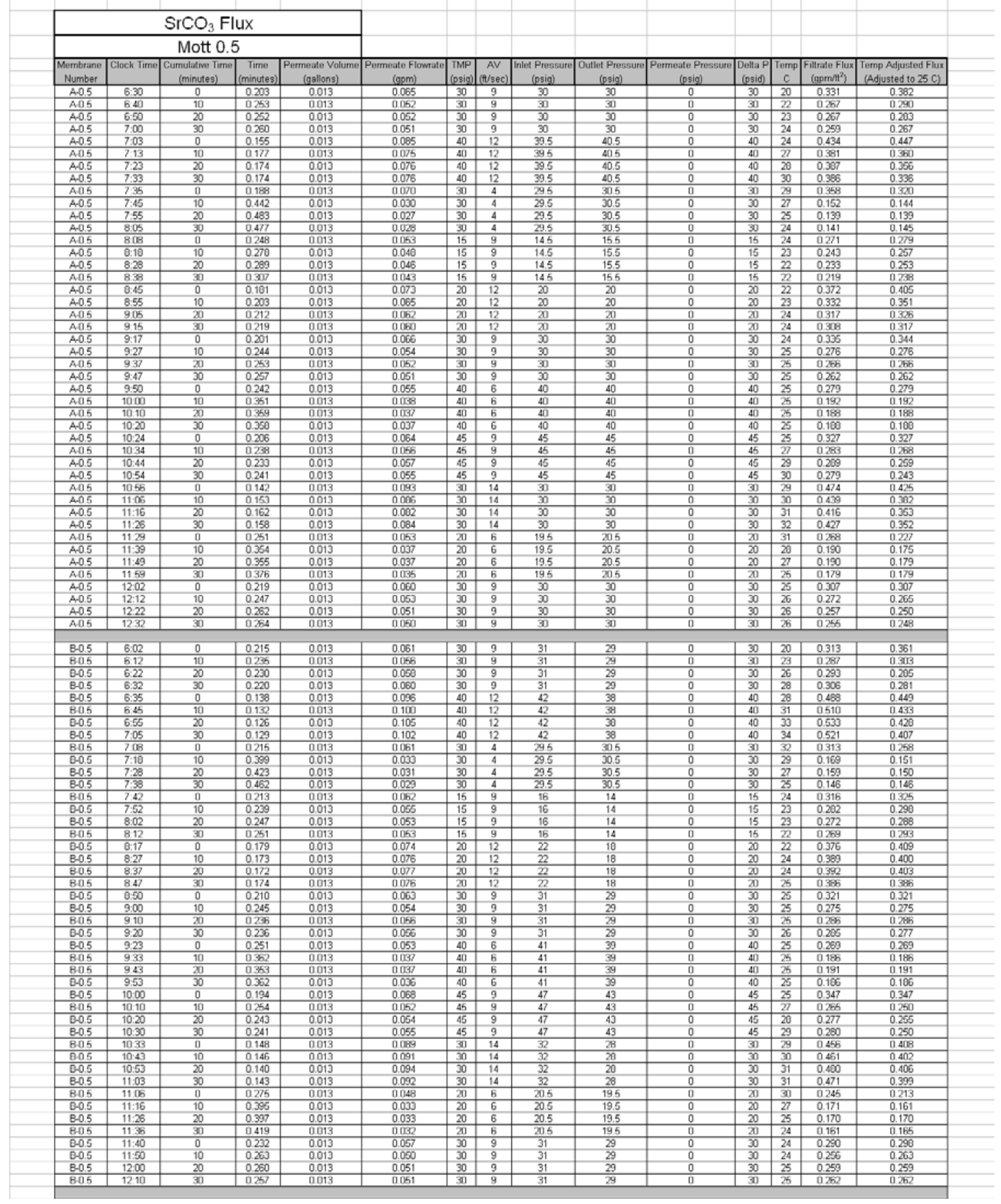


Table D-3. Strontium Carbonate Flux-Mott $0.5 \mu \mathrm{m}$ (continued).

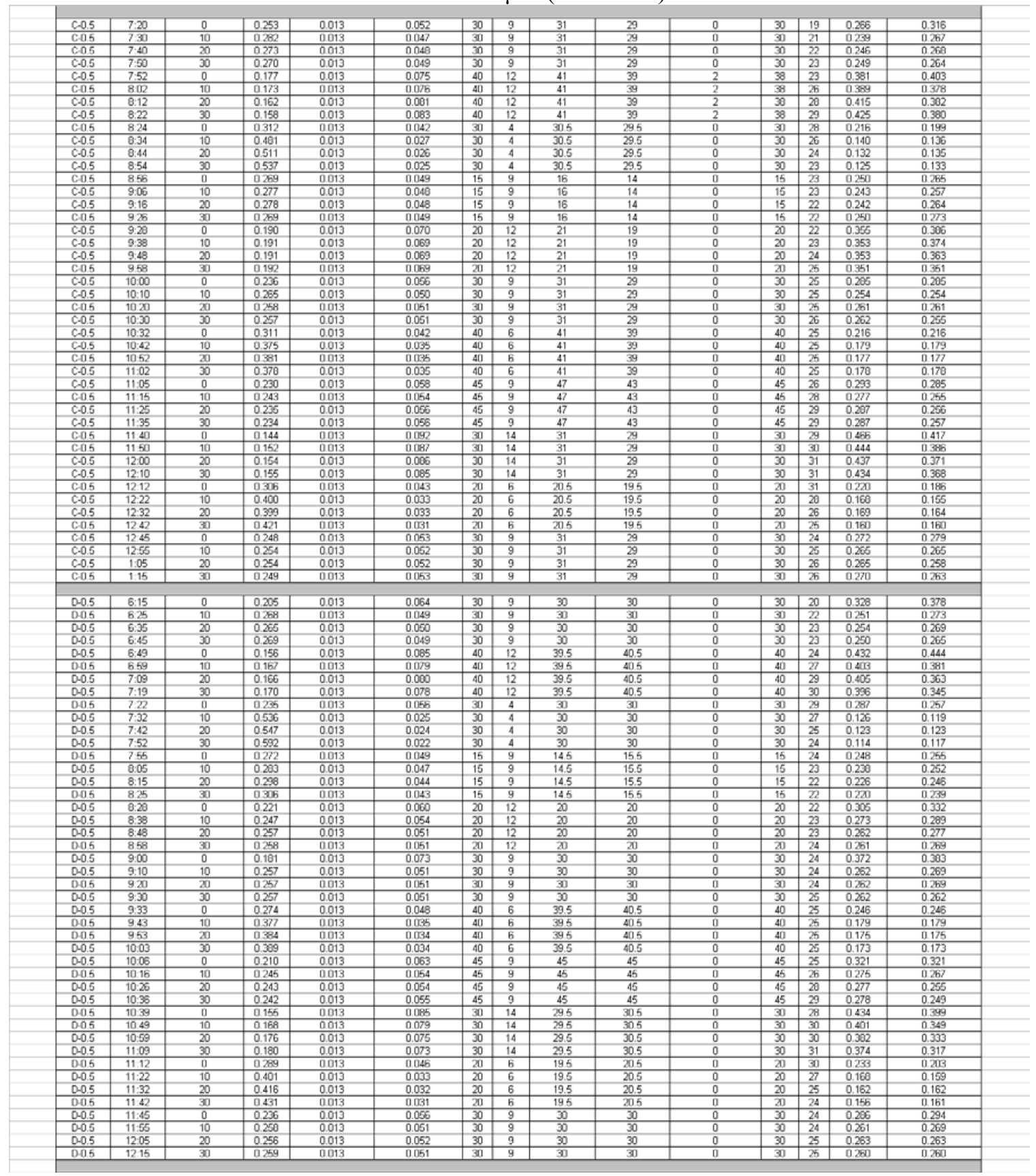


Table D-3. Strontium Carbonate Flux-Mott $0.5 \mu \mathrm{m}$ (continued).

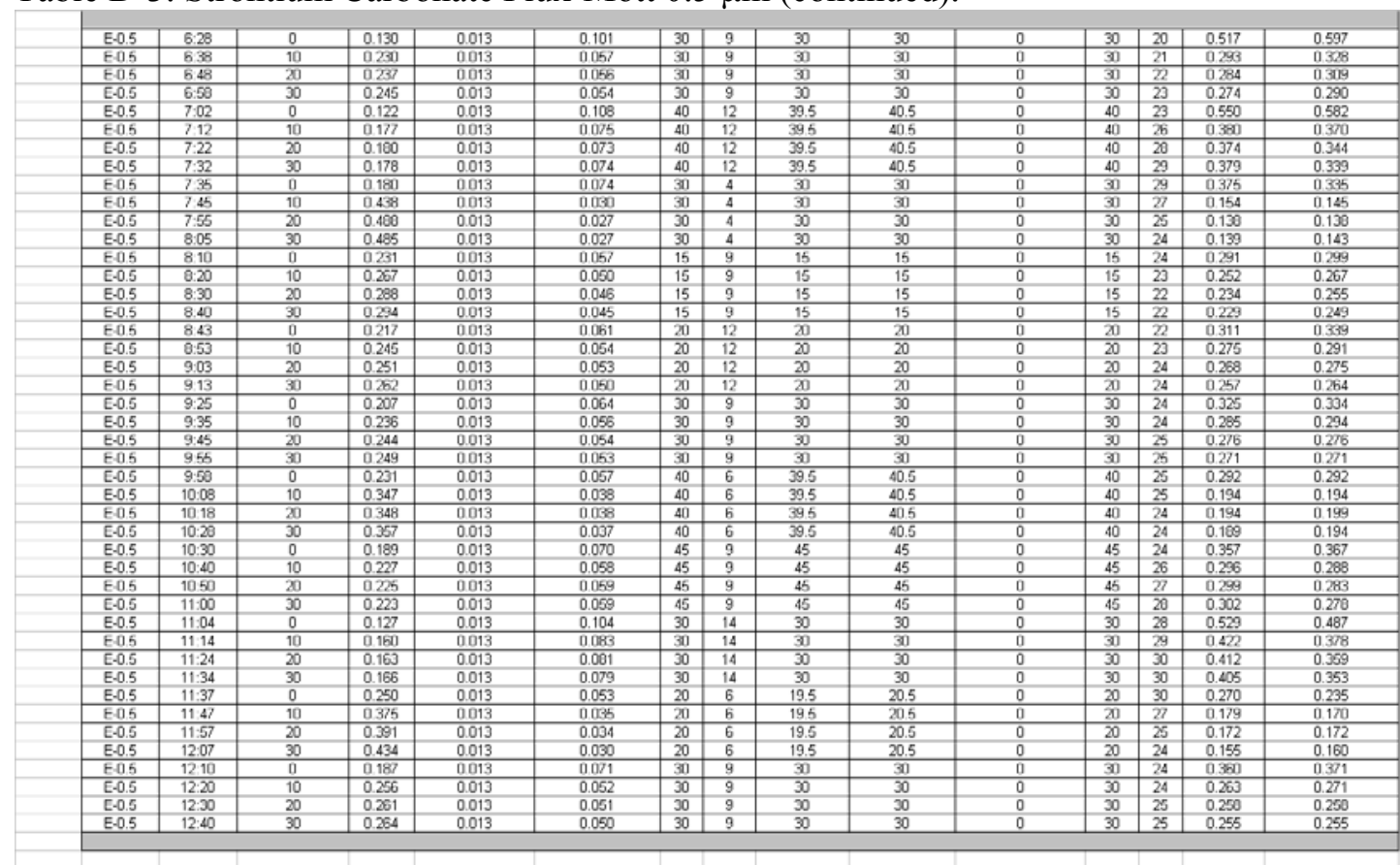


Table D-4. Strontium Carbonate Flux (Pall $0.1 \mu \mathrm{m})$.

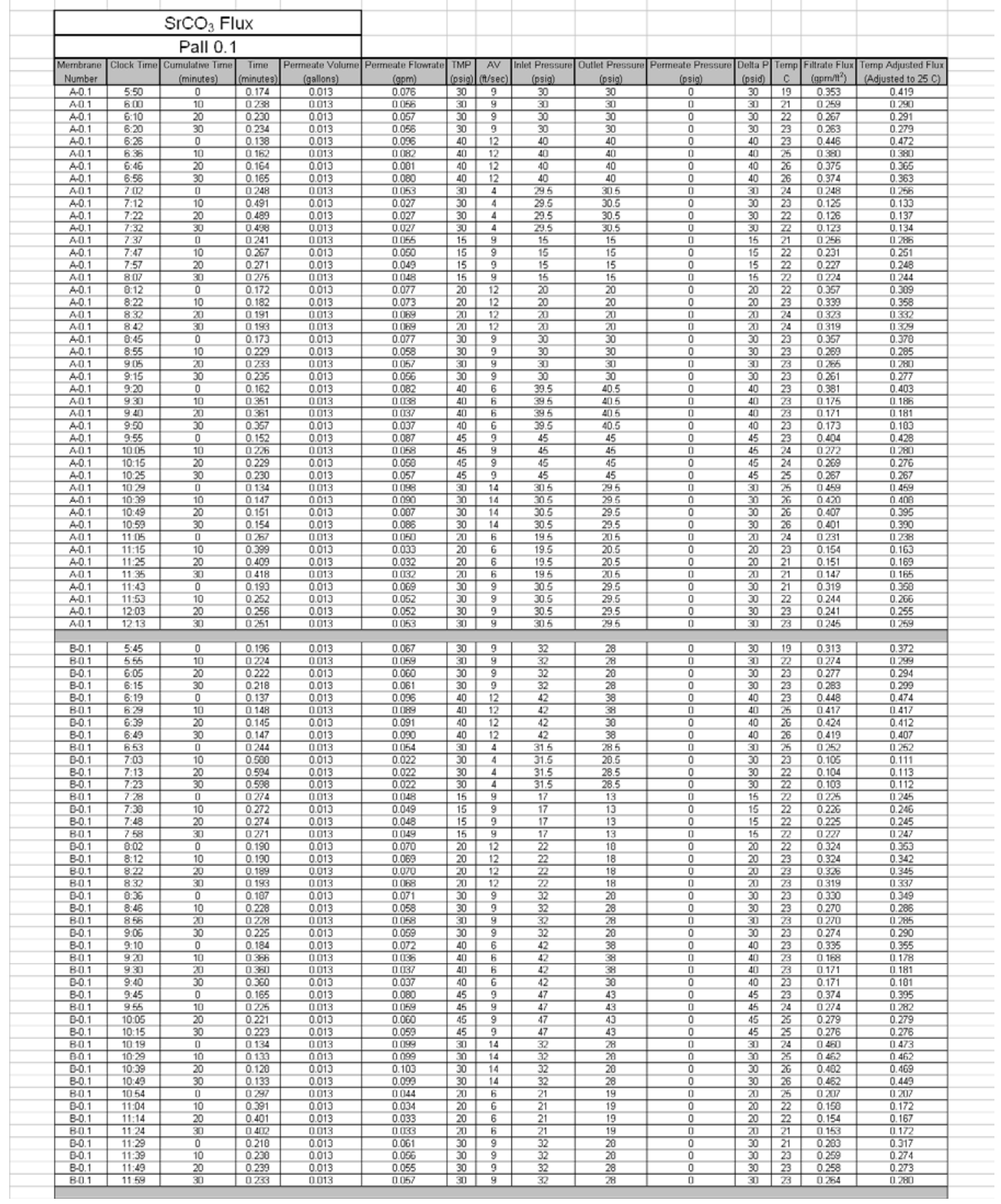


Table D-4. Strontium Carbonate Flux-Pall 0.1 $\mu \mathrm{m}$ (continued).

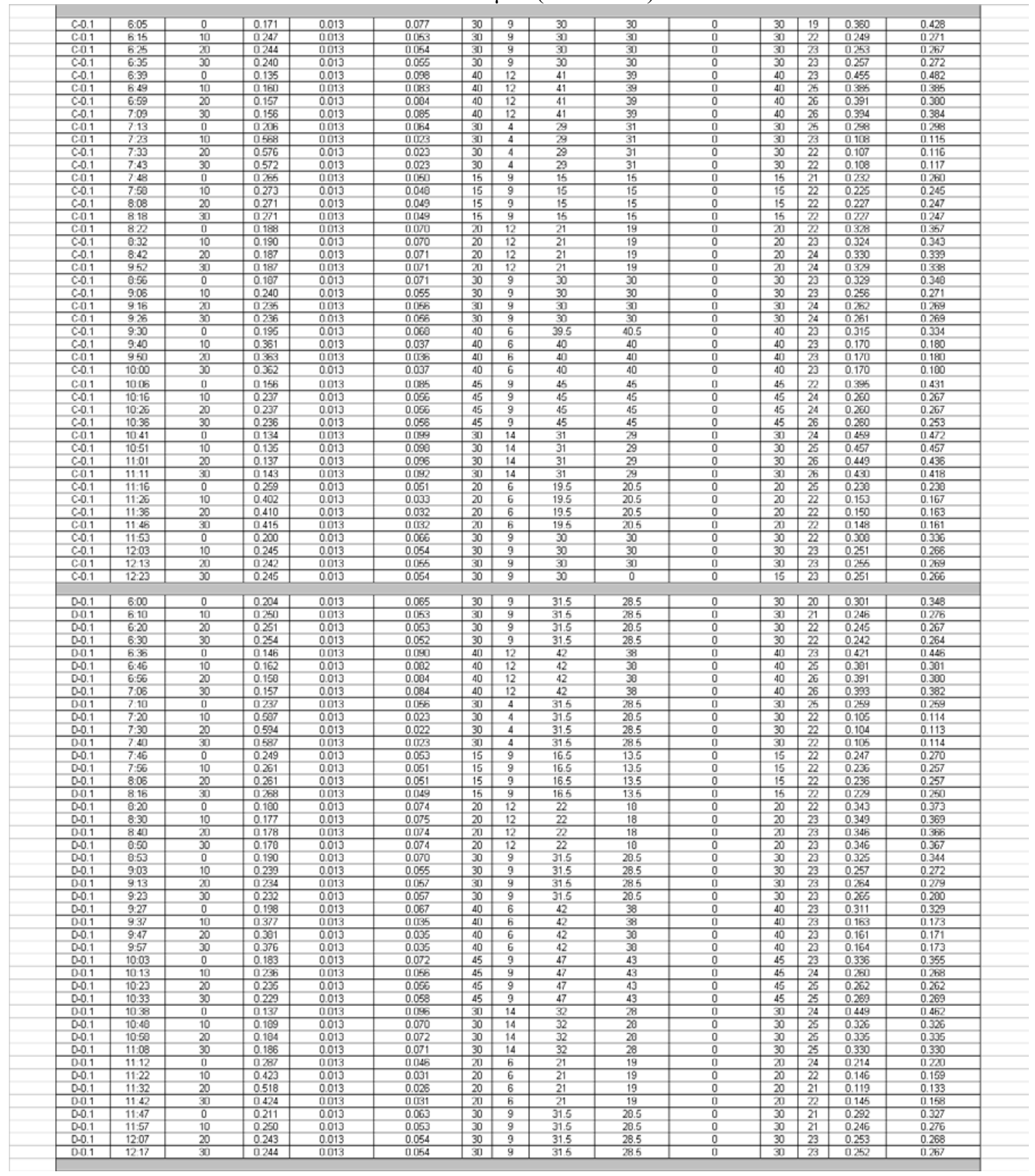


Table D-4. Strontium Carbonate Flux-Pall $0.1 \mu \mathrm{m}$ (continued).

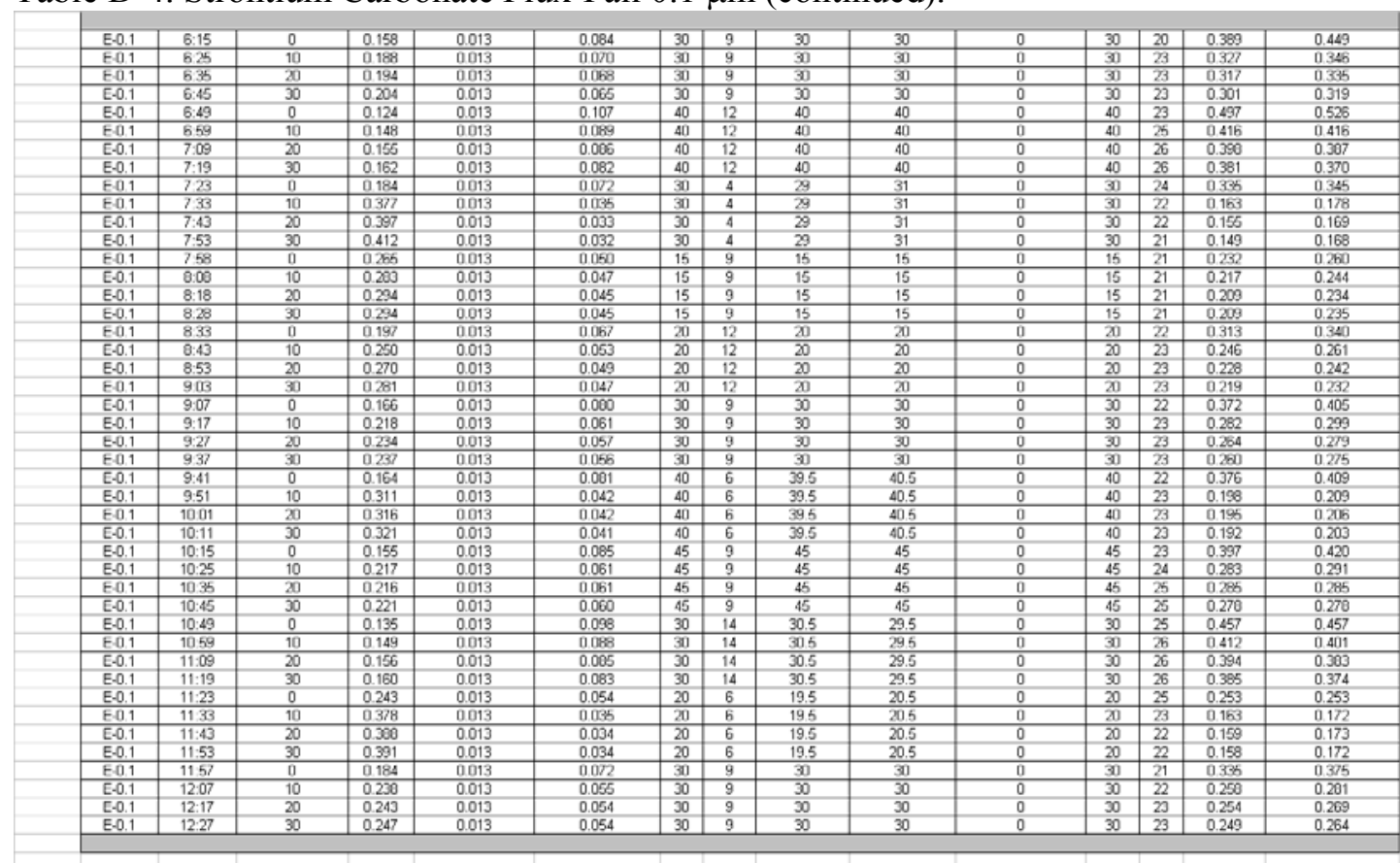


Table D-5. Strontium Carbonate Flux (Pall $0.8 \mu \mathrm{m})$.

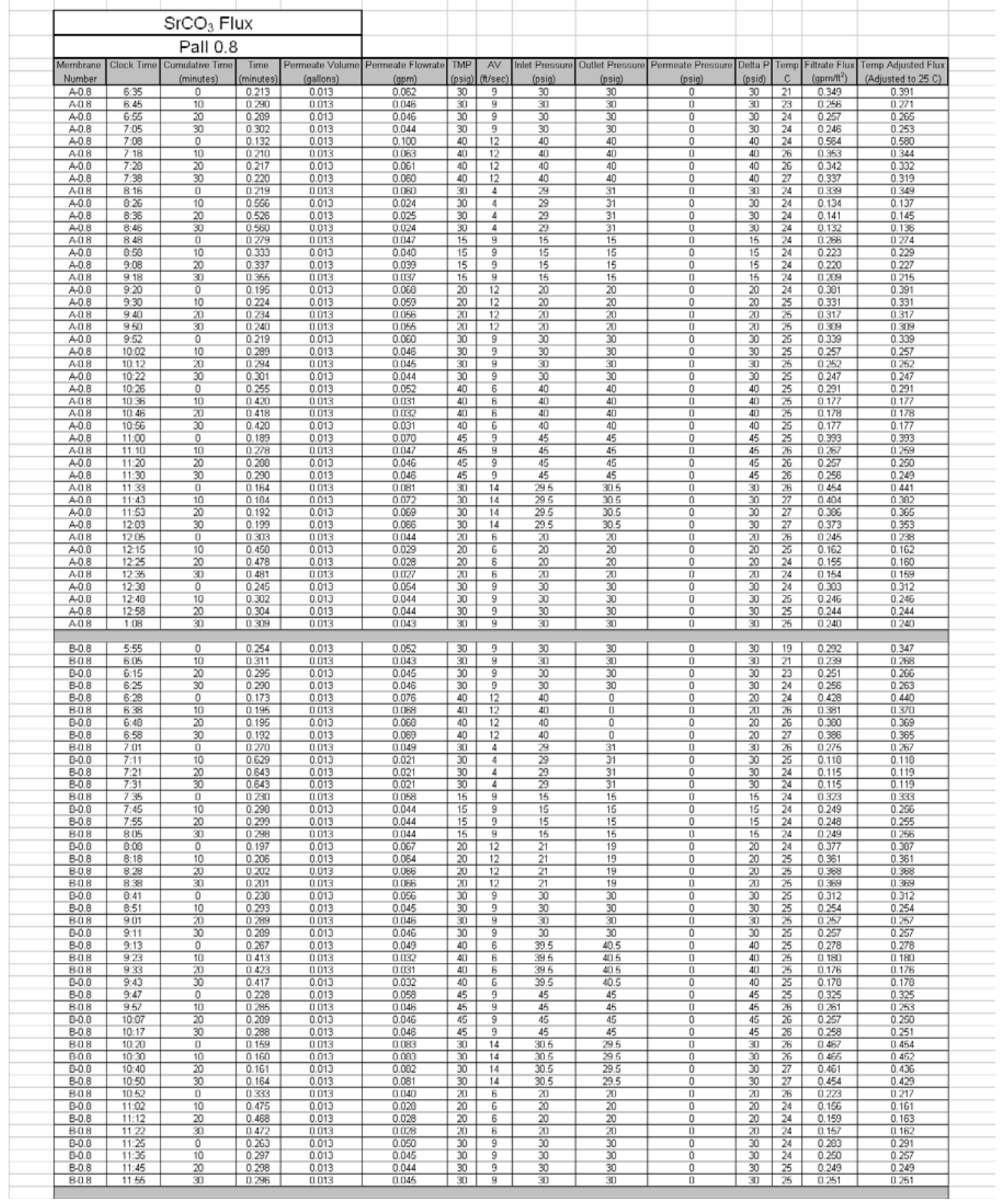


Table D-5. Strontium Carbonate Flux-Pall $0.8 \mu \mathrm{m}$ (continued).

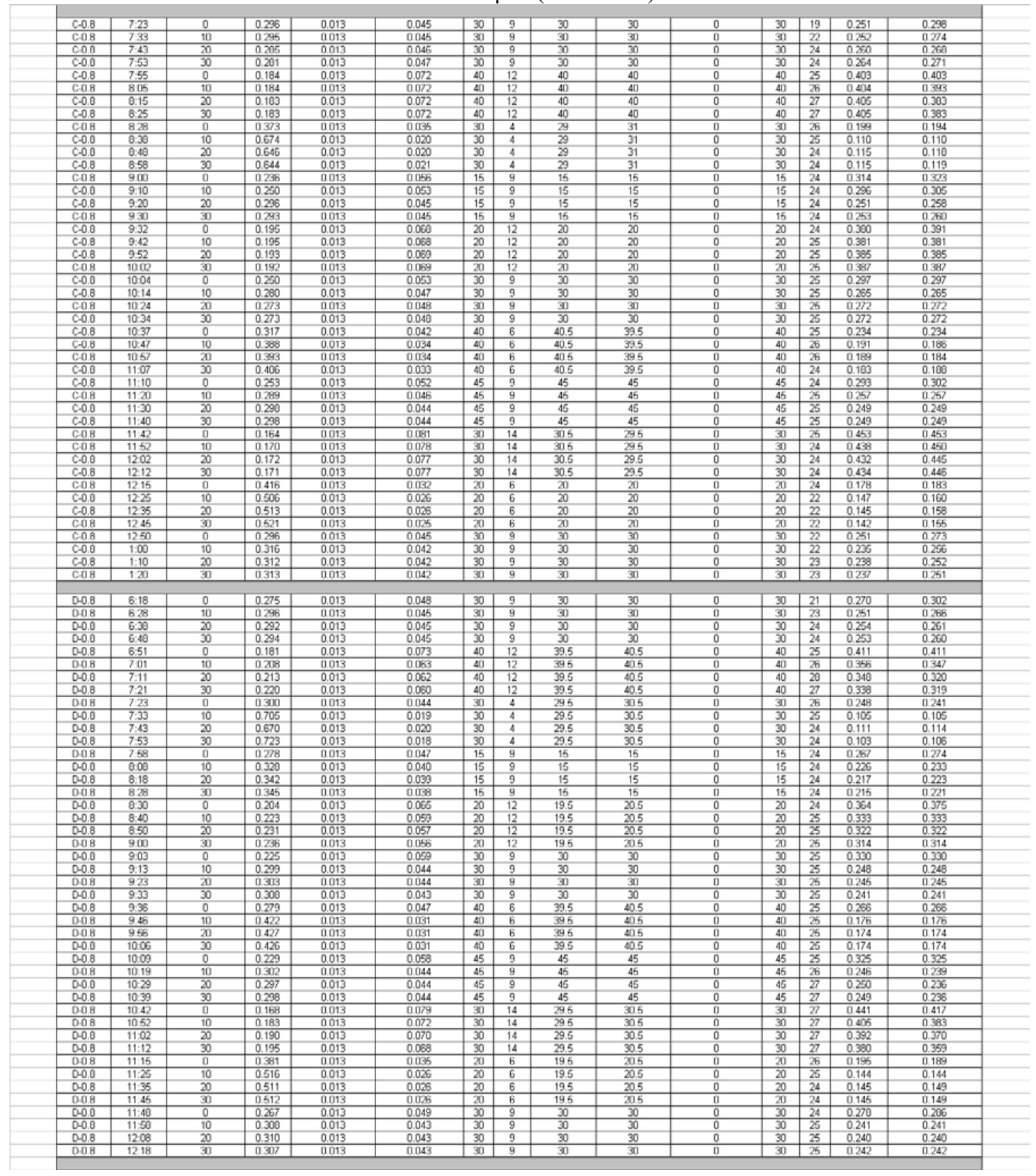


Table D-5. Strontium Carbonate Flux-Pall $0.8 \mu \mathrm{m}$ (continued).

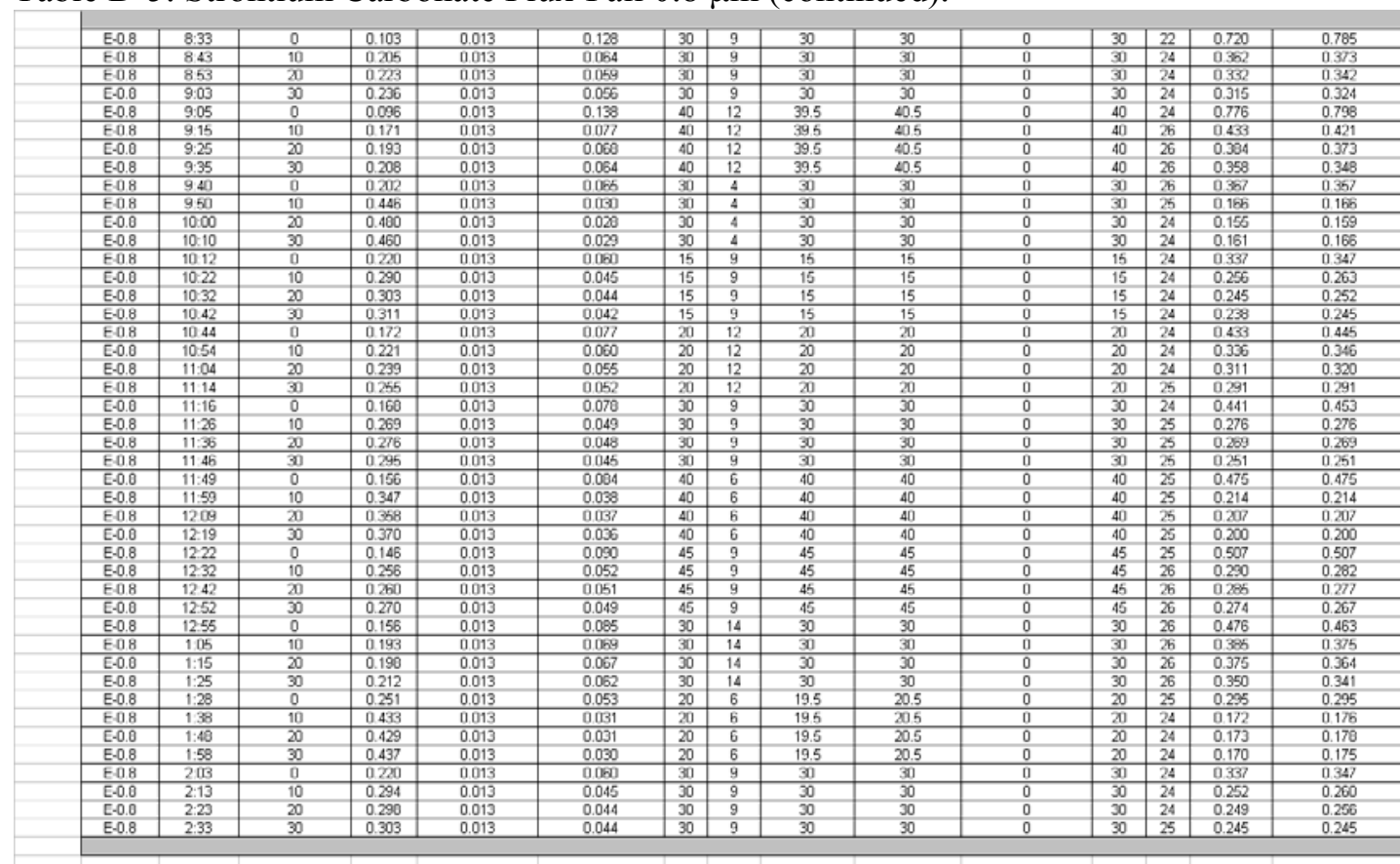


Table D-6. Strontium Carbonate Flux (GKN $0.1 \mu \mathrm{m}$ ).

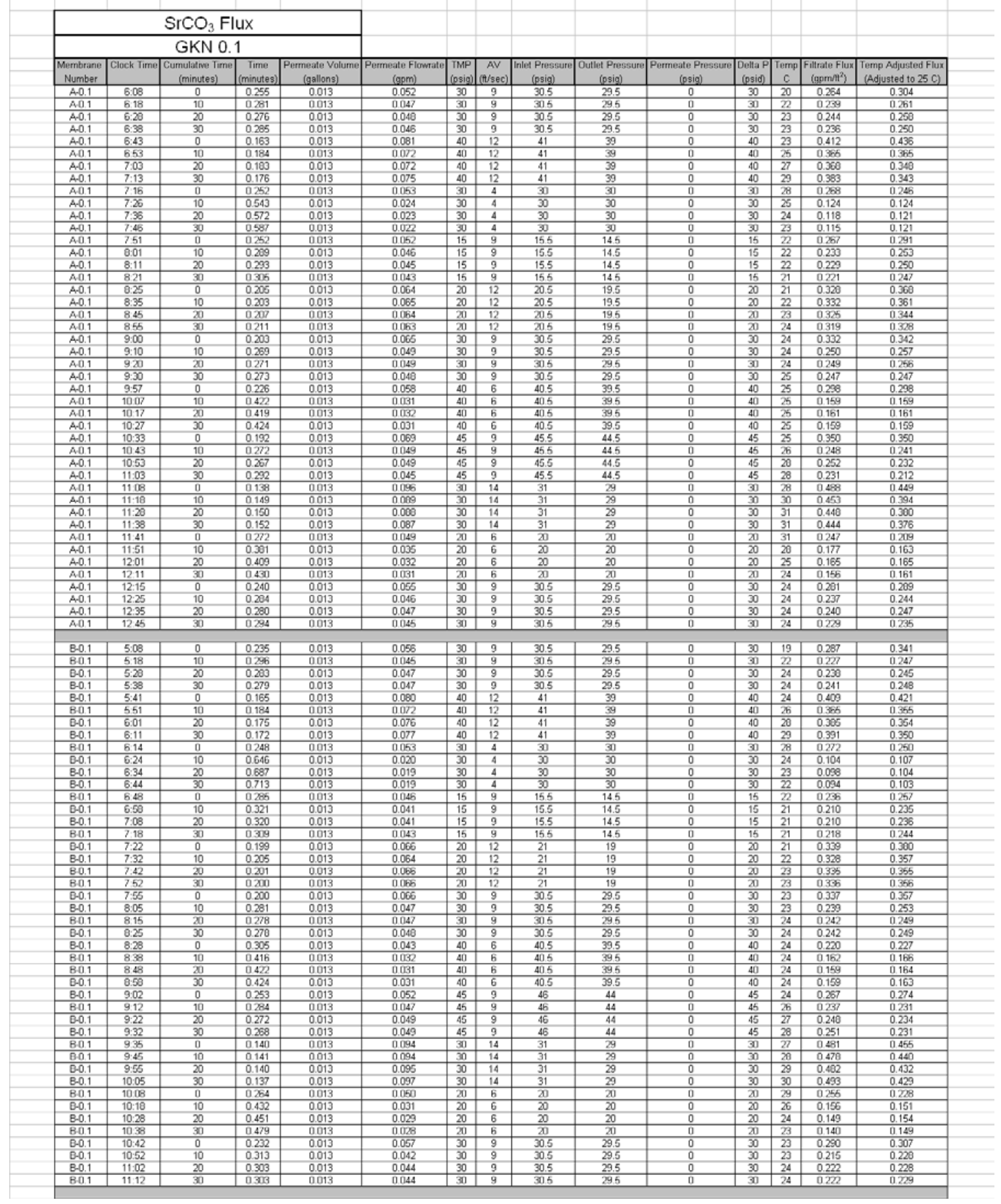


Table D-6. Strontium Carbonate Flux-GKN 0.1 $\mu \mathrm{m}$ (continued).

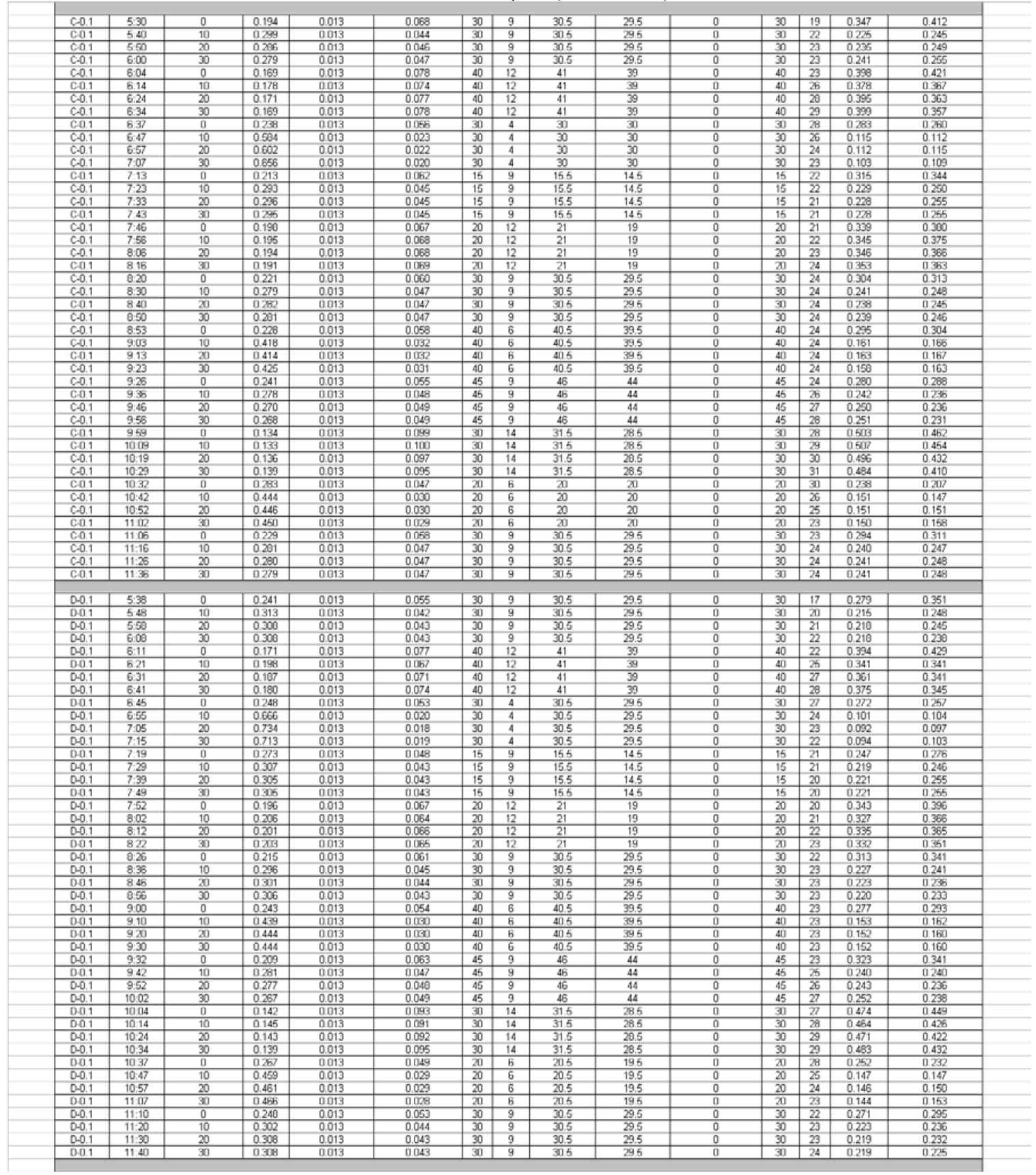


Table D-6. Strontium Carbonate Flux-GKN $0.1 \mu \mathrm{m}$ (continued).

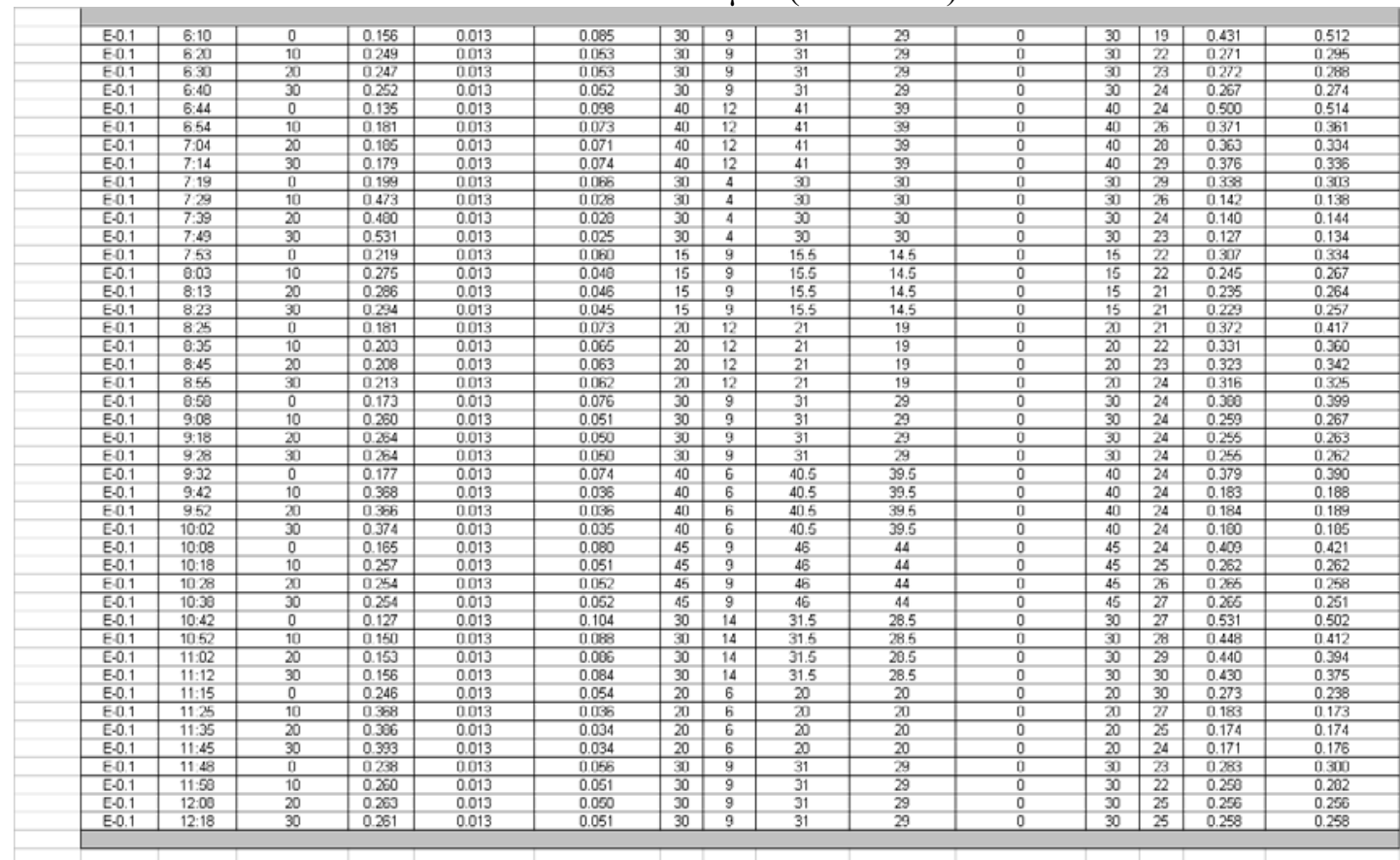


Appendix E

SRS Simulant 0.29 wt\% 


\section{Appendix E}

\section{SRS Simulant $0.29 \mathrm{wt} \%$}

Table E-1. SRS Simulant $0.29 \mathrm{wt} \%$ (Graver $0.07 \mu \mathrm{m}$ ).

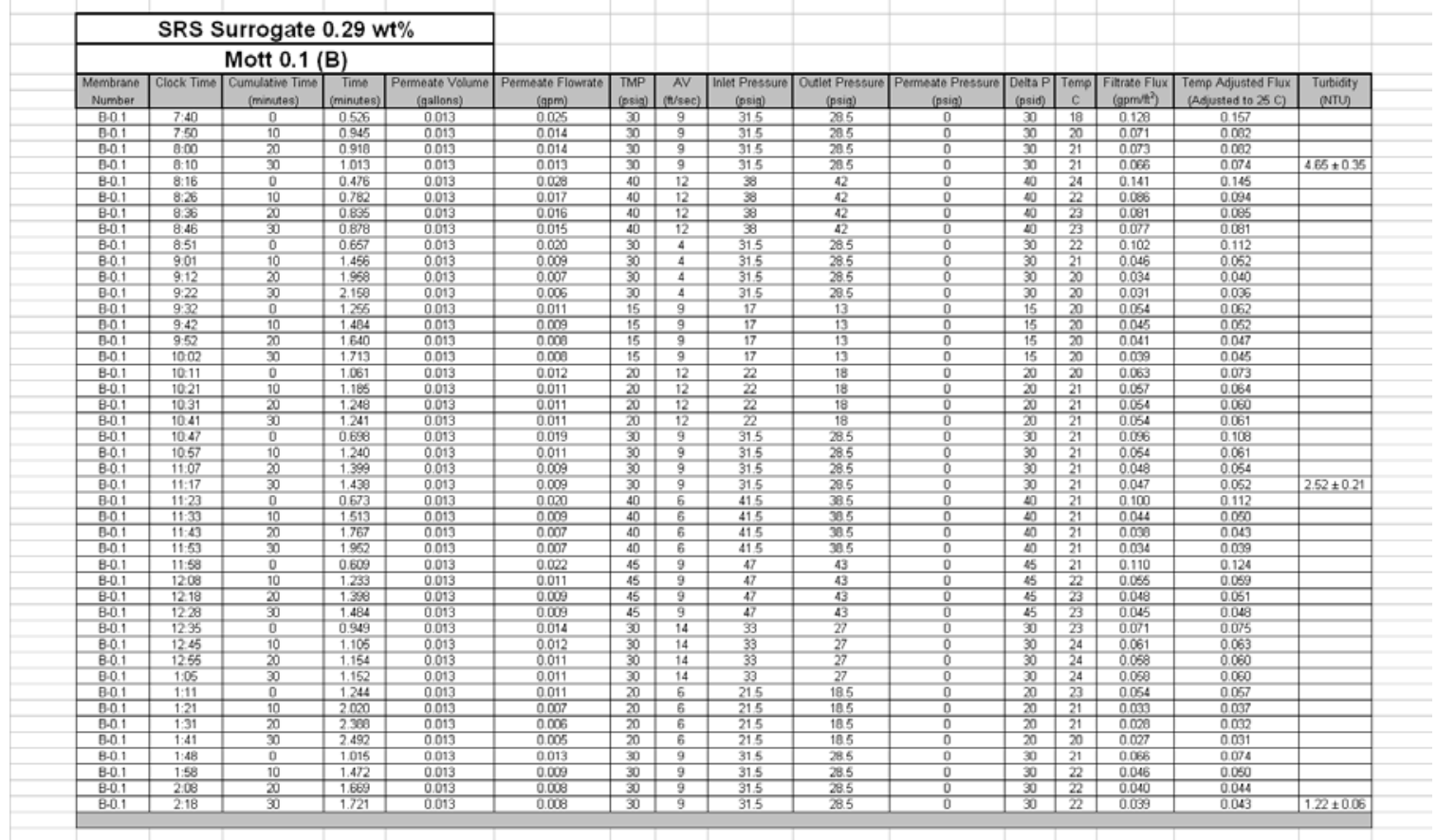

Table E-2. SRS Simulant 0.29 wt $\%$ (Mott $0.1 \mu \mathrm{m}$ ).

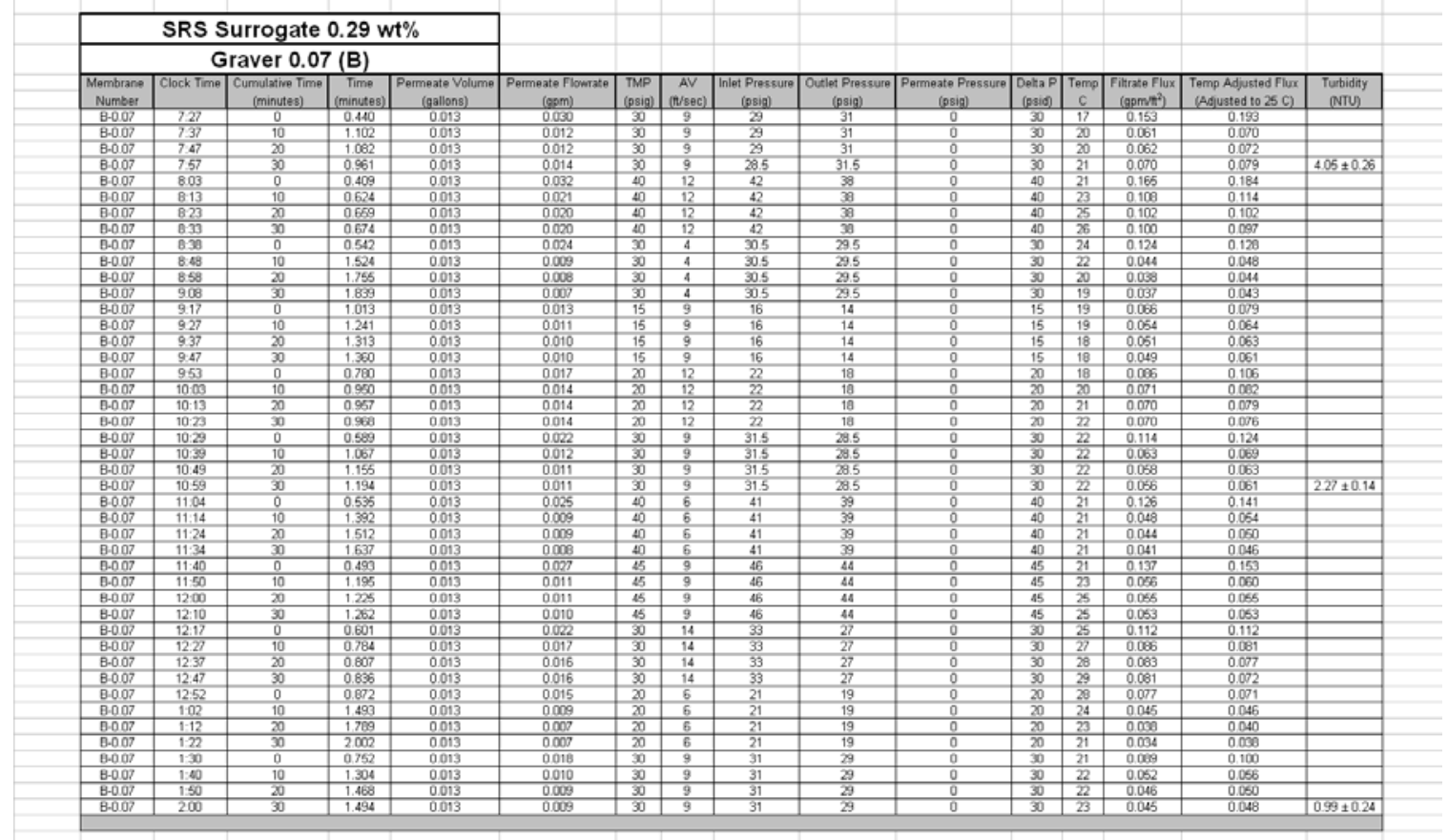


Table E-3. SRS Simulant 0.29 wt $\%$ (Mott $0.5 \mu \mathrm{m}$ ).

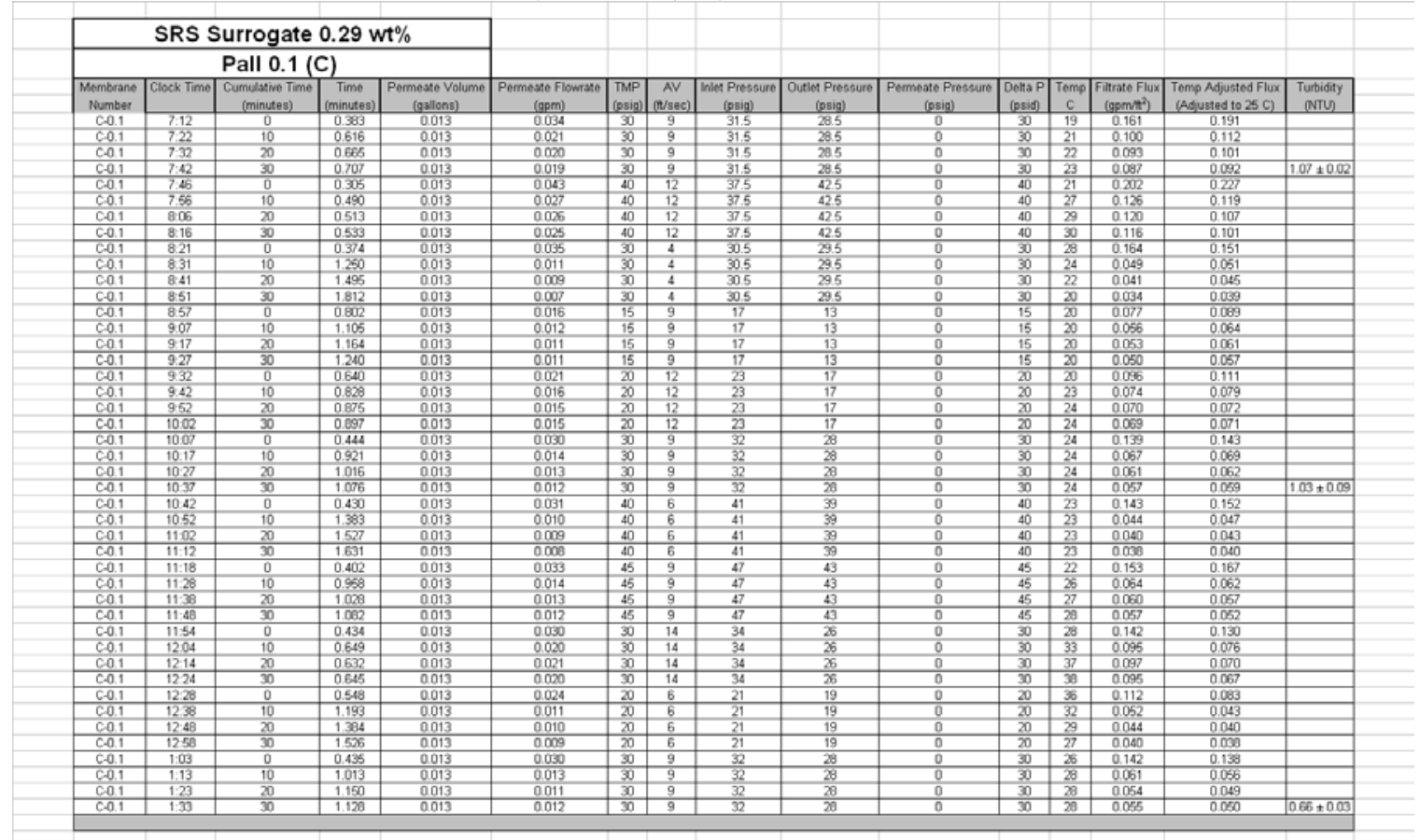

Table E-4. SRS Simulant $0.29 \mathrm{wt} \%$ (Pall $0.1 \mu \mathrm{m})$.

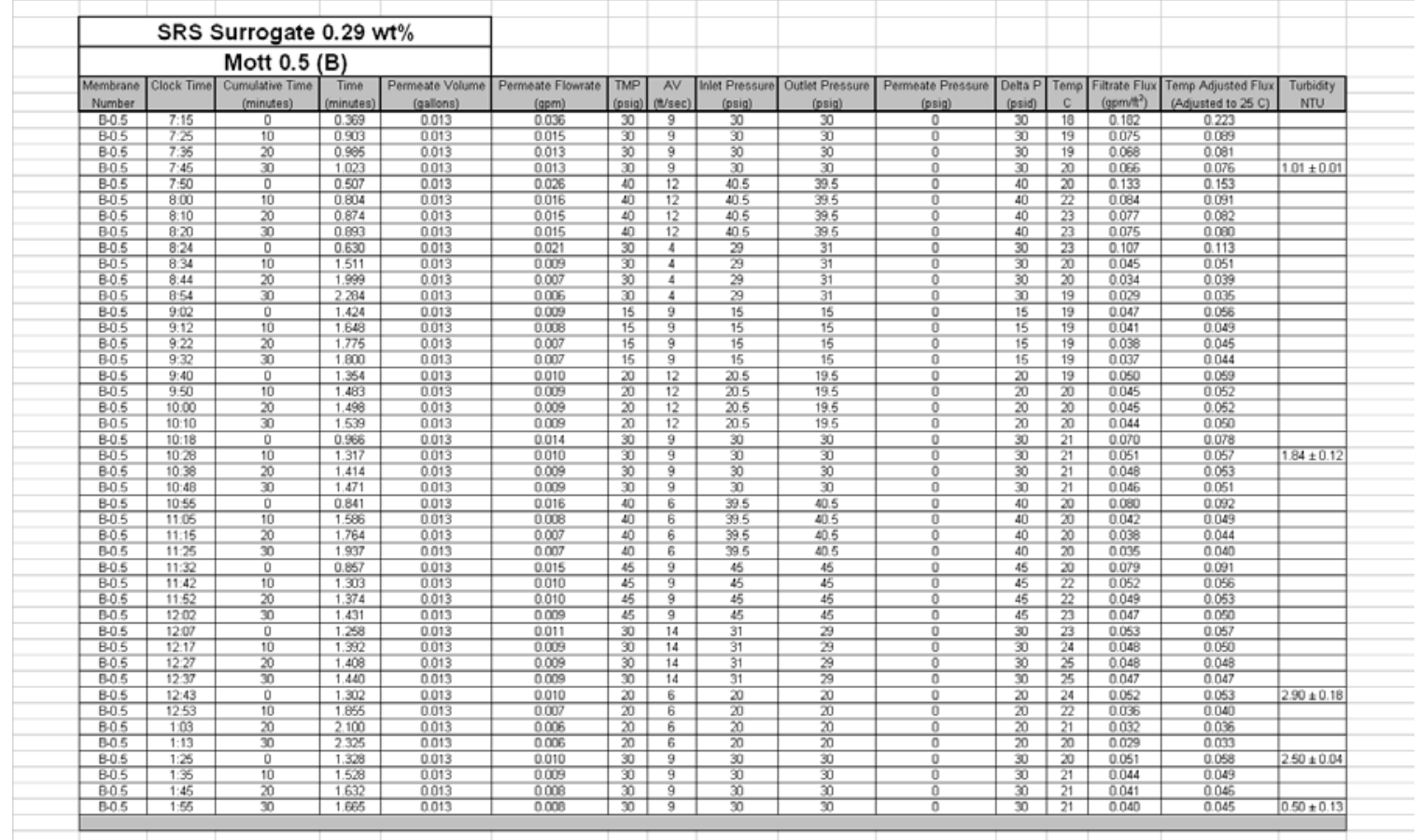


Table E-5. SRS Simulant 0.29 wt $\%$ (Pall $0.8 \mu \mathrm{m})$.

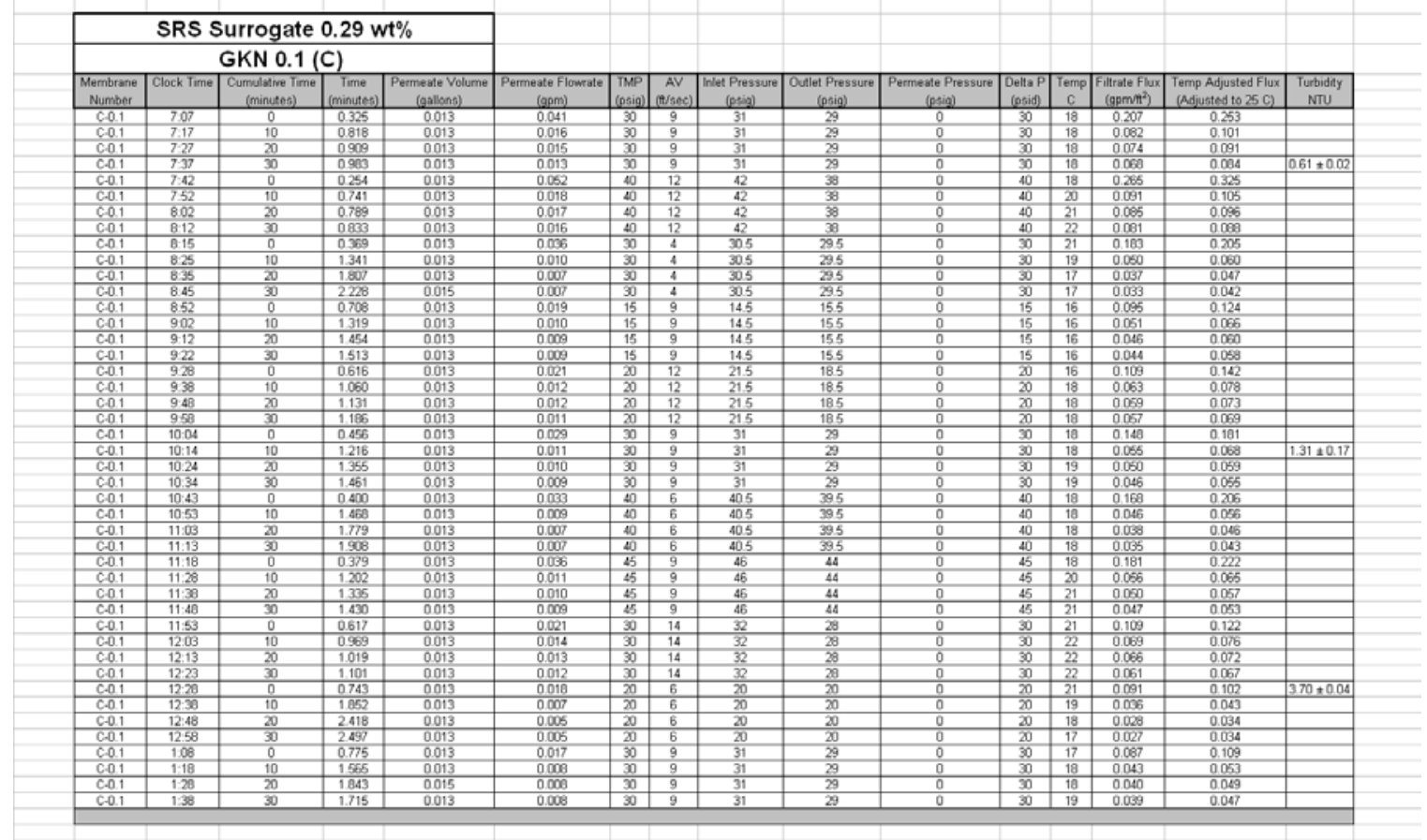

Table E-6. SRS Simulant 0.29 wt $\%$ (GKN $0.1 \mu \mathrm{m})$.

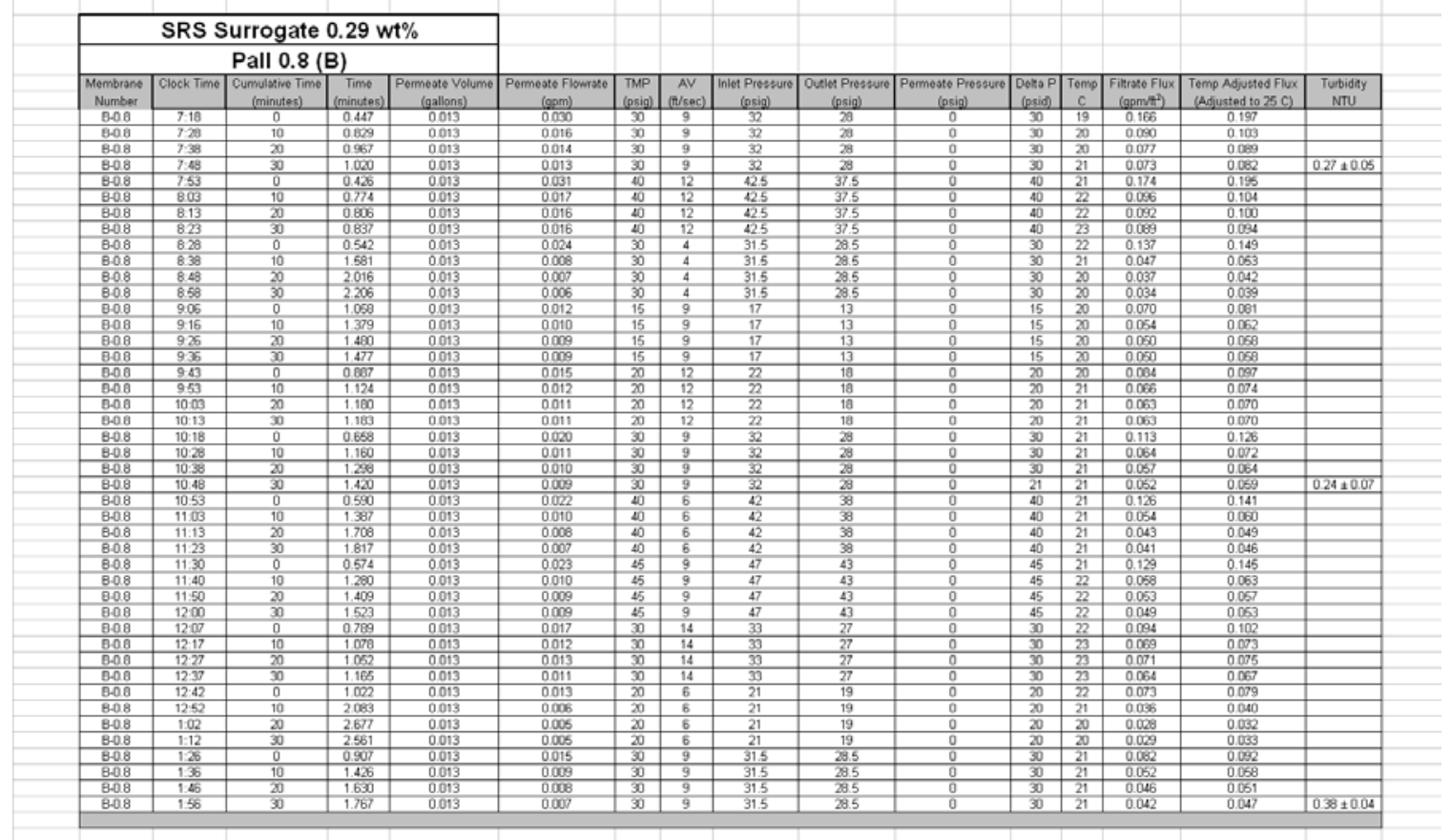




\section{Appendix F \\ SRS Simulant 4.5 wt $\%$}




\section{Appendix F}

\section{SRS Simulant $4.5 \mathrm{wt} \%$}

Table F-1. SRS Simulant $4.5 \mathrm{wt} \%$ (Graver $0.07 \mu \mathrm{m})$.

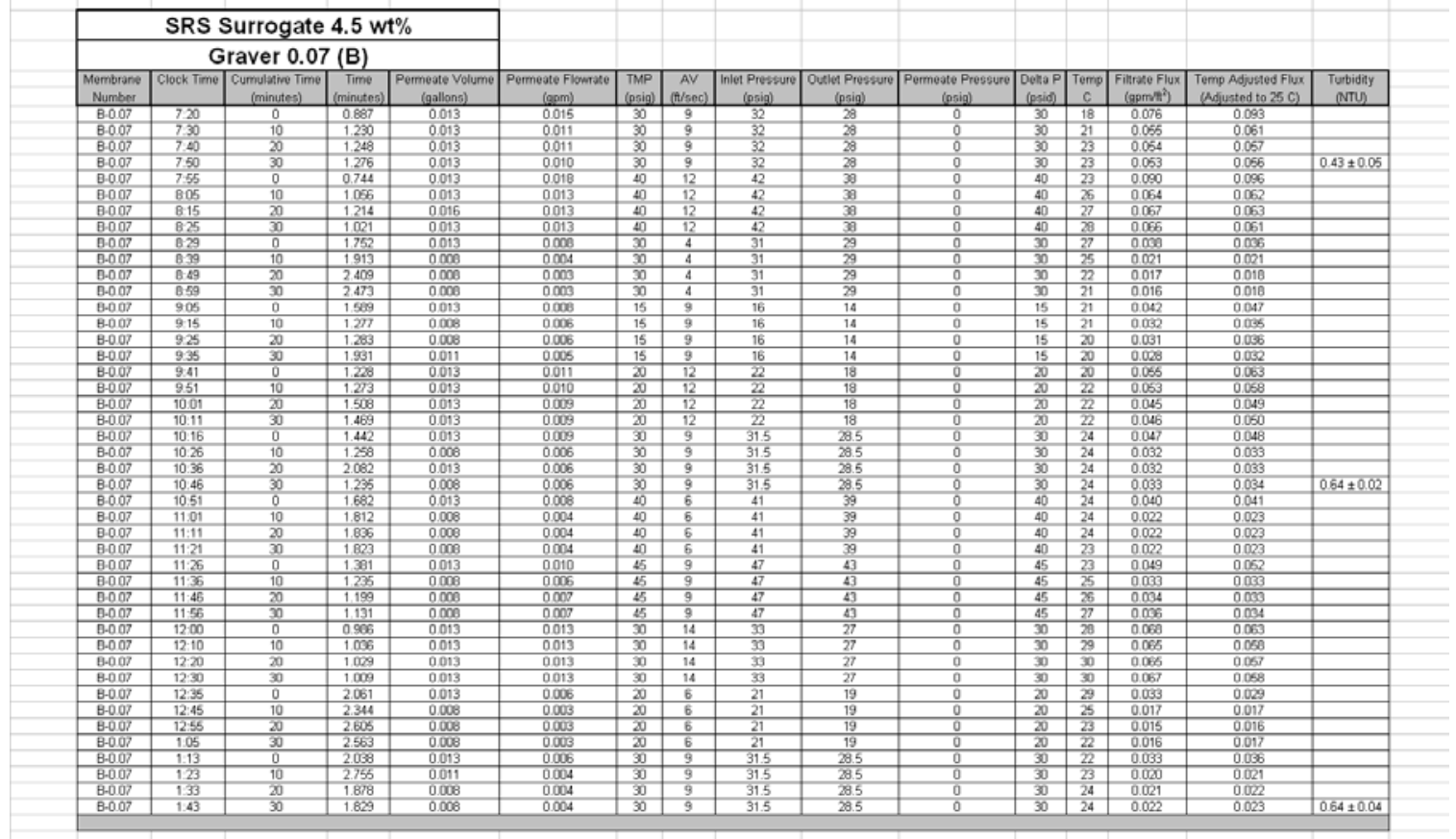

Table F-2. SRS Simulant $4.5 \mathrm{wt} \%$ (Mott $0.1 \mu \mathrm{m}$ ).

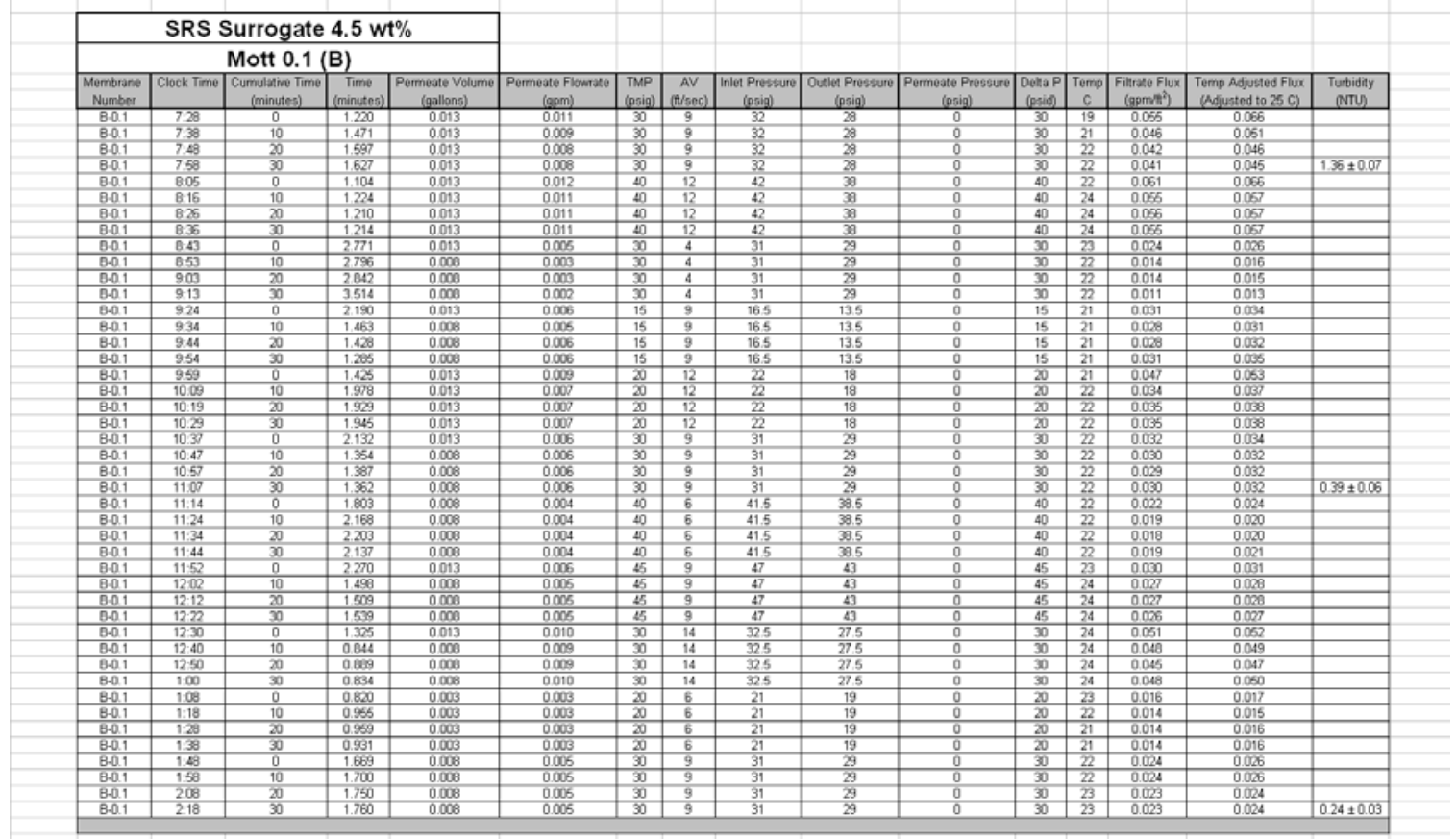


Table F-3. SRS Simulant $4.5 \mathrm{wt} \%$ (Mott $0.5 \mu \mathrm{m}$ ).

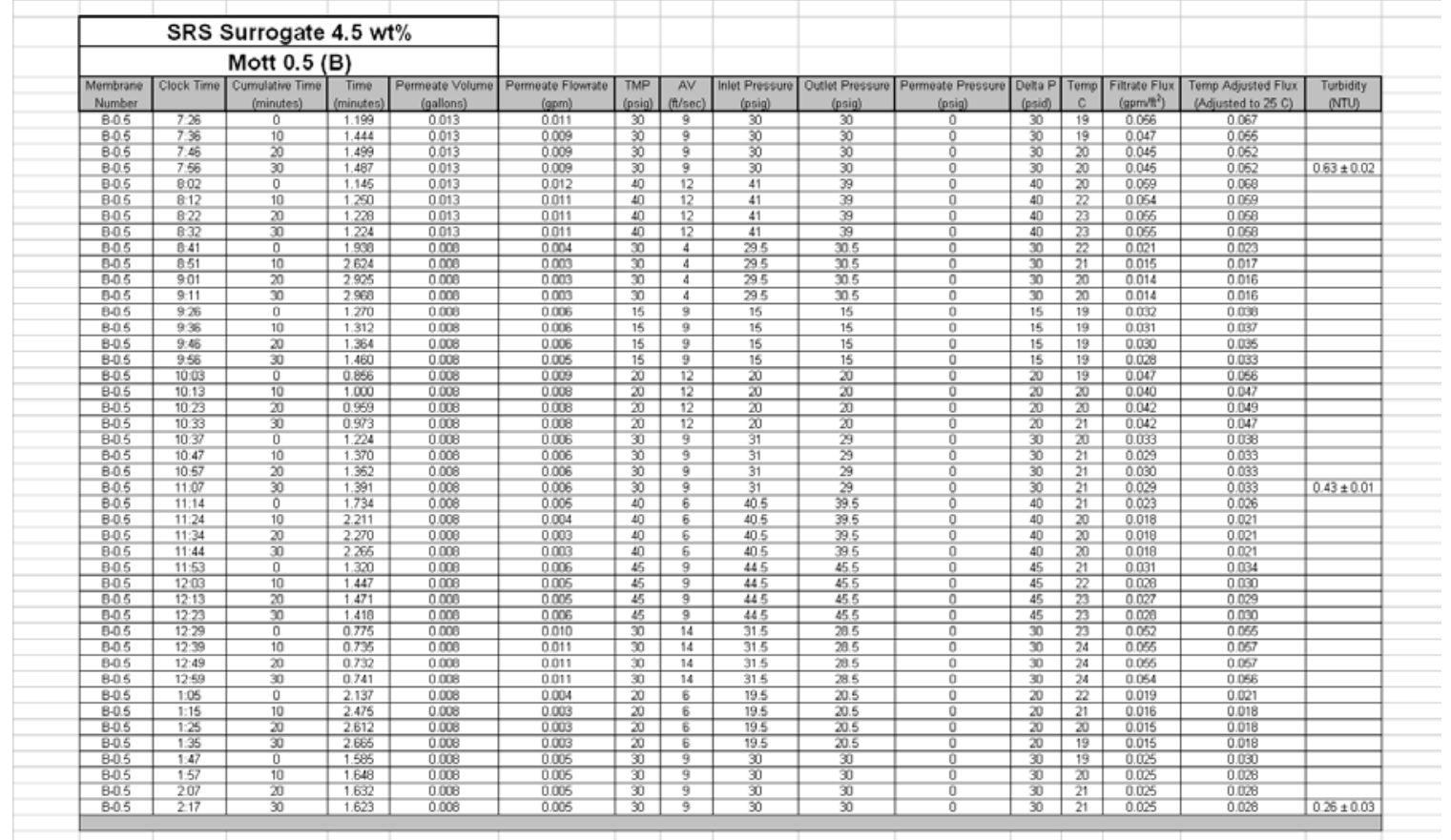

Table F-4. SRS Simulant 4.5 wt $\%$ (Pall $0.1 \mu \mathrm{m}$ ).

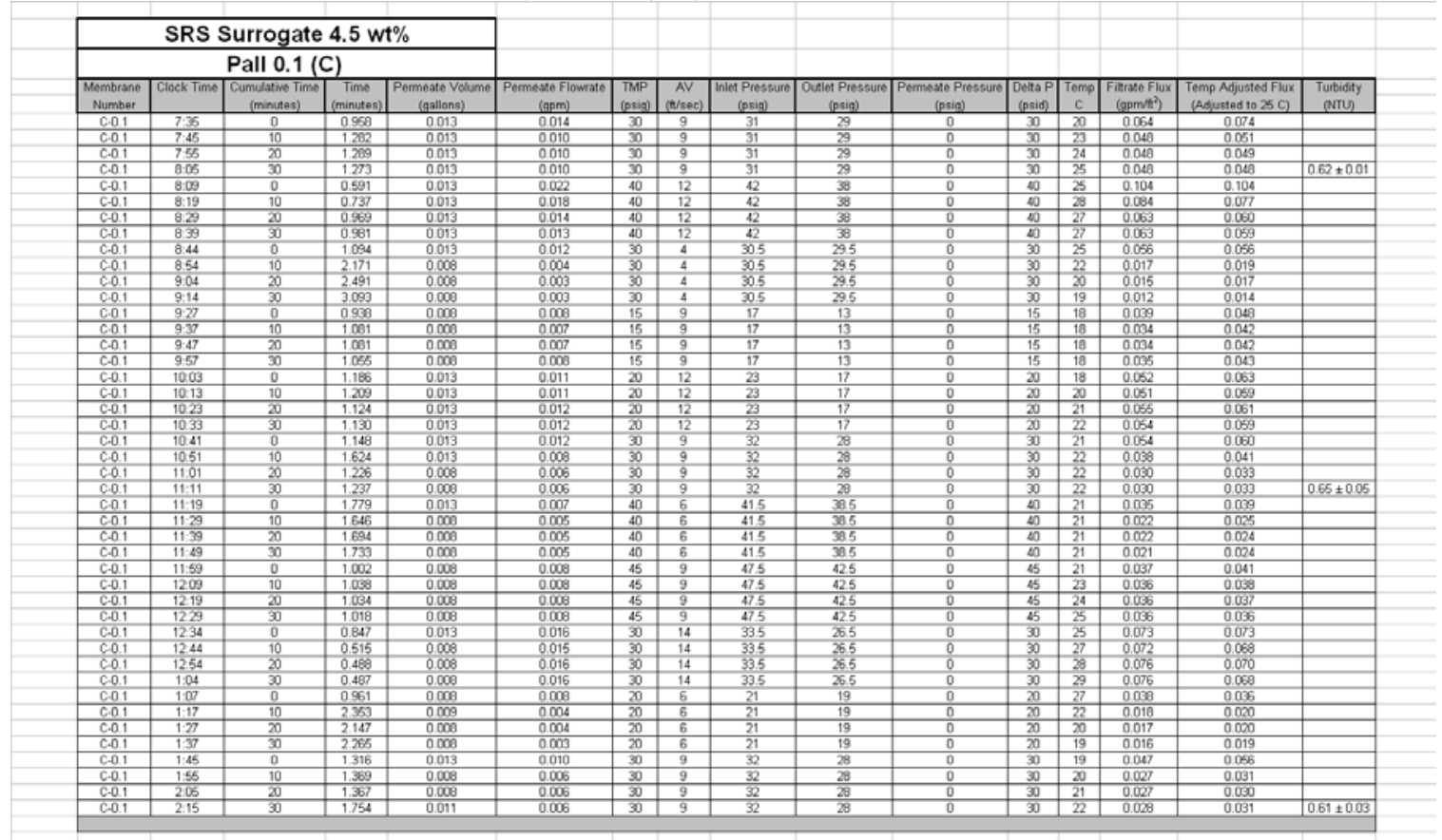


Table F-5. SRS Simulant 4.5 wt $\%$ (Pall $0.8 \mu \mathrm{m}$ ).

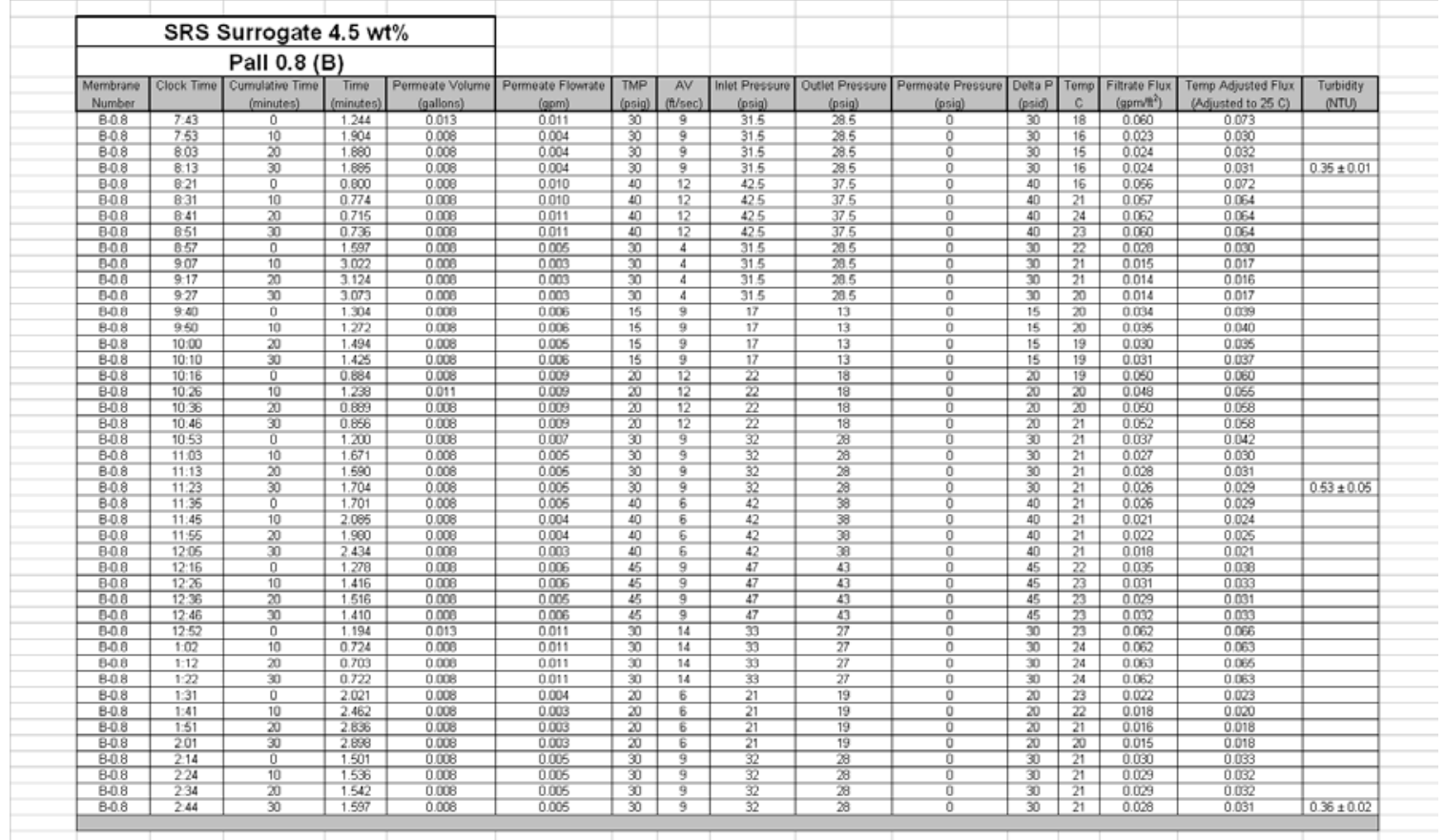

Table F-6. SRS Simulant 4.5 wt\% (GKN $0.1 \mu \mathrm{m})$.

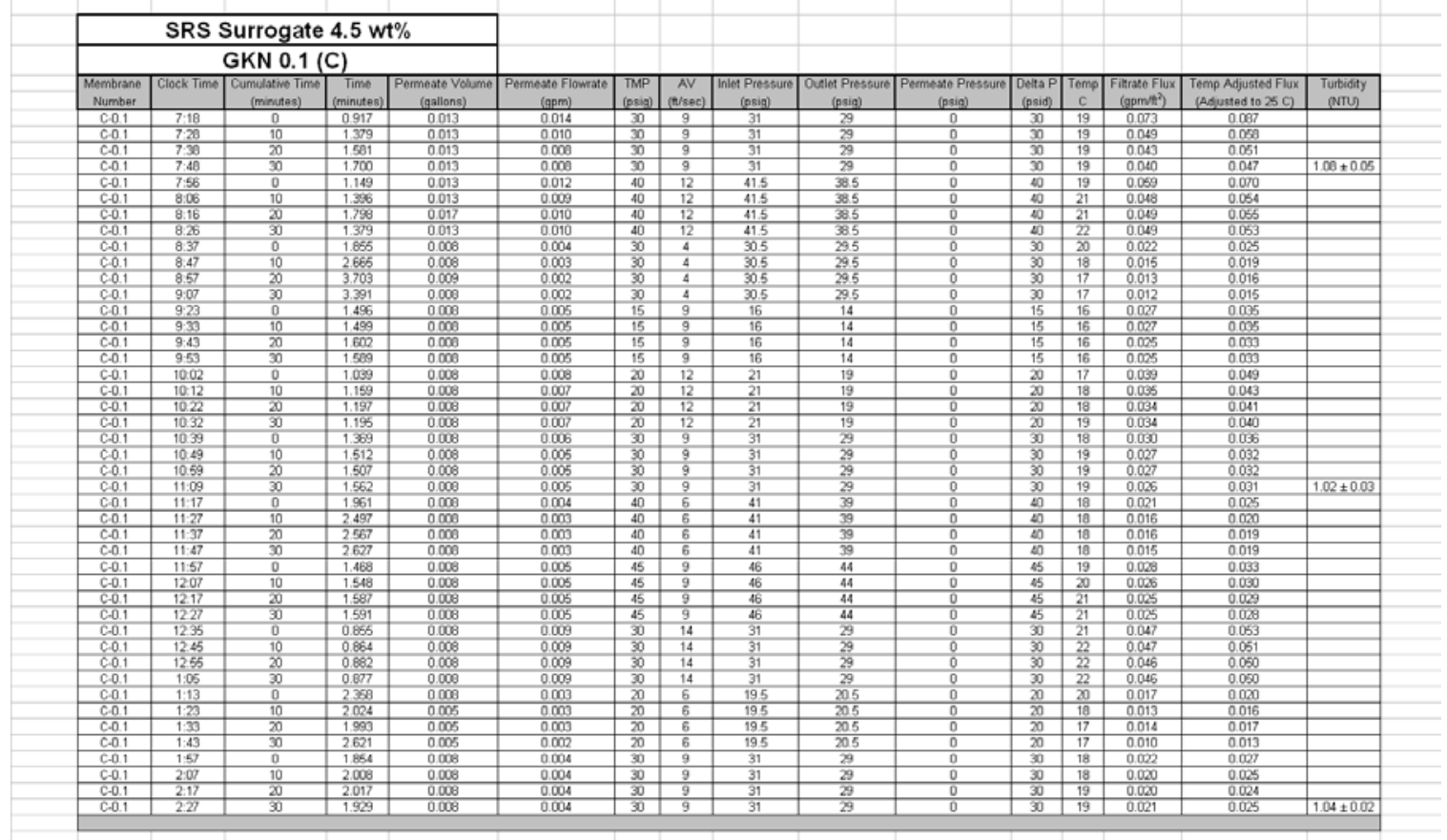




\section{Appendix G}

\section{SRS Simulant 4.5 wt $\%$ \\ Repeat}




\section{Appendix G \\ SRS Simulant $4.5 \mathrm{wt} \%$ \\ Repeat}

Table G-1. SRS Simulant 4.5 wt $\%$ Repeat (GKN $0.1 \mu \mathrm{m})$.

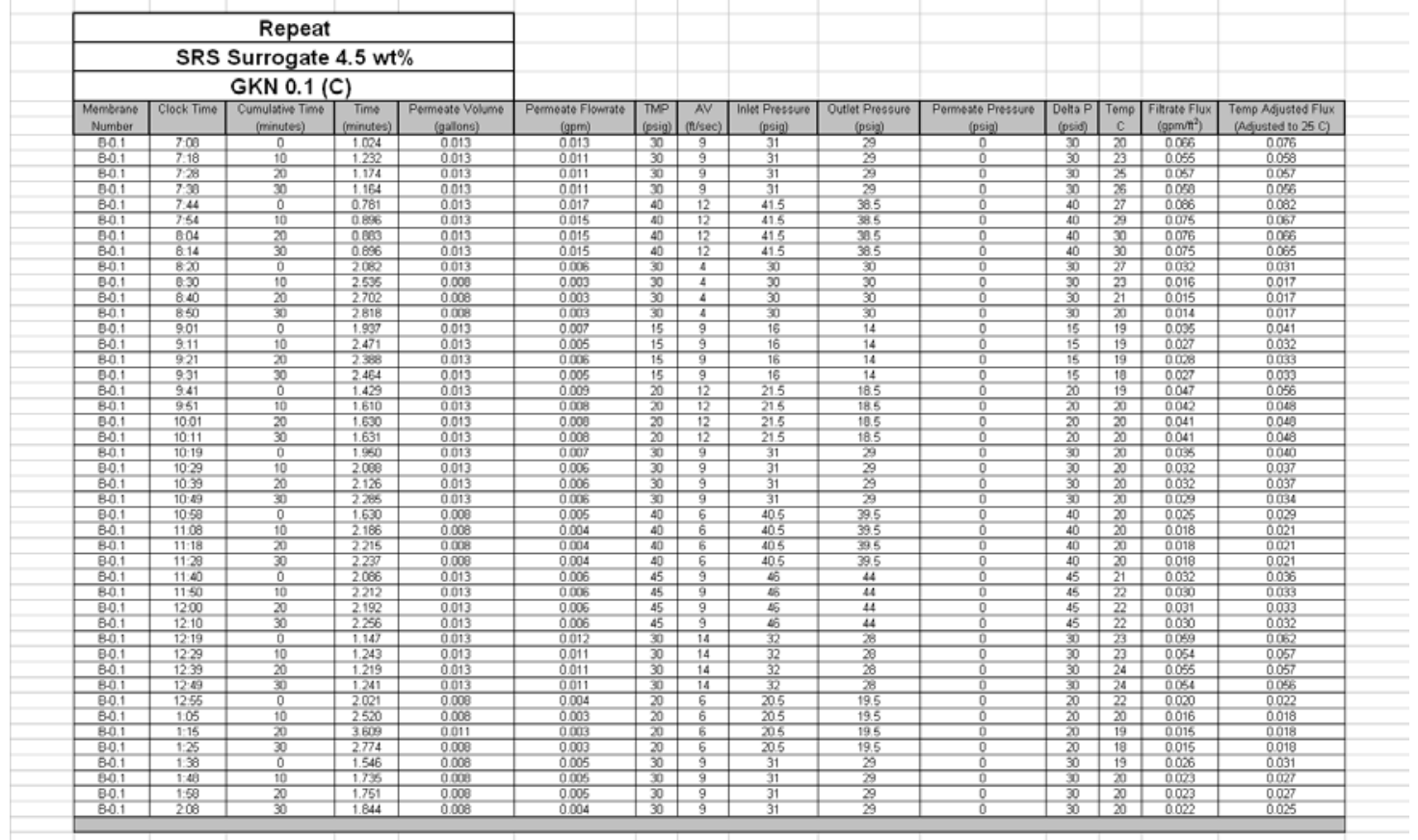

Table G-2. SRS Simulant $4.5 \mathrm{wt} \%$ Repeat (Mott $0.5 \mu \mathrm{m}$ ).

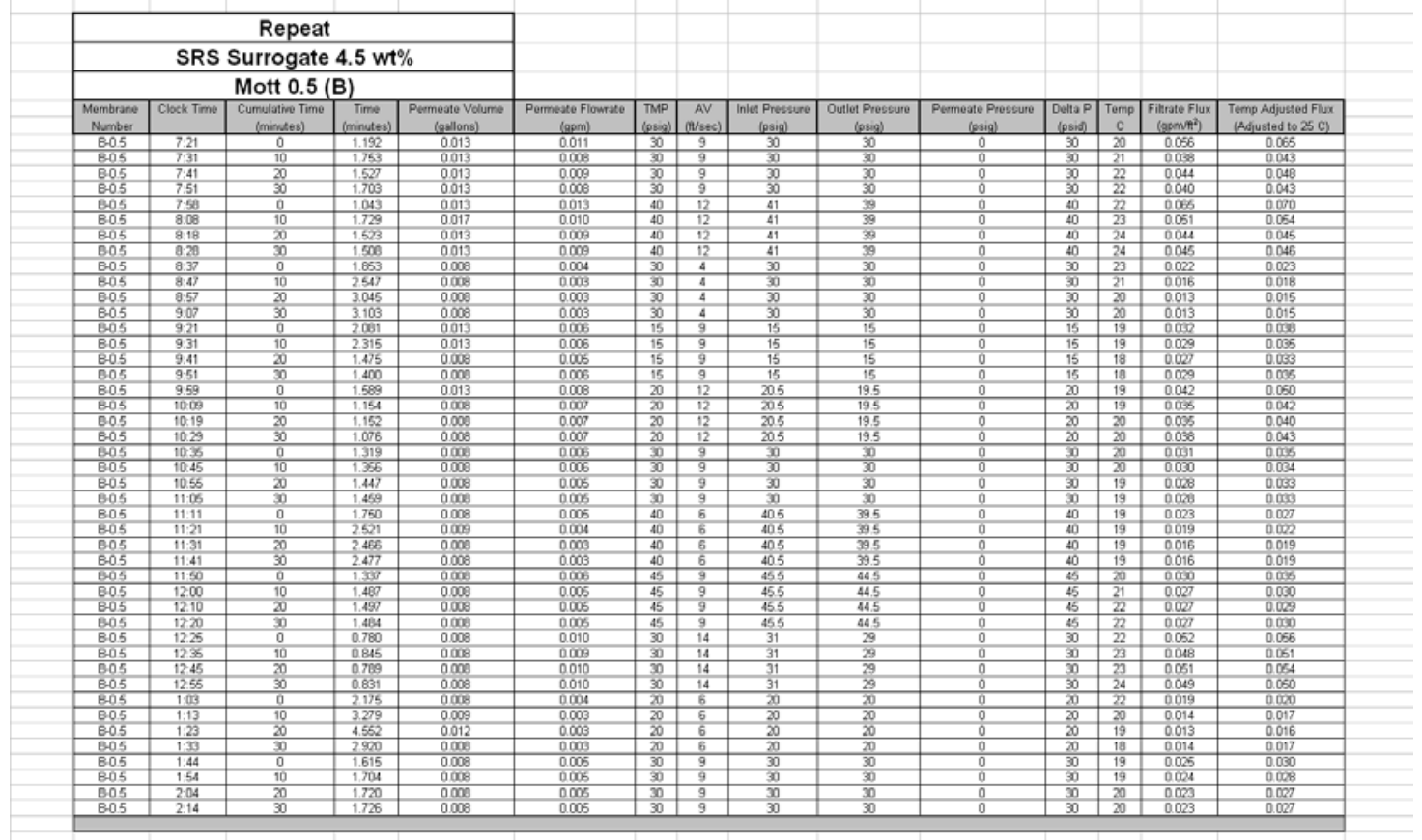


Table G-3. SRS Simulant 4.5 wt $\%$ Repeat (Graver $0.07 \mu \mathrm{m}$ ).

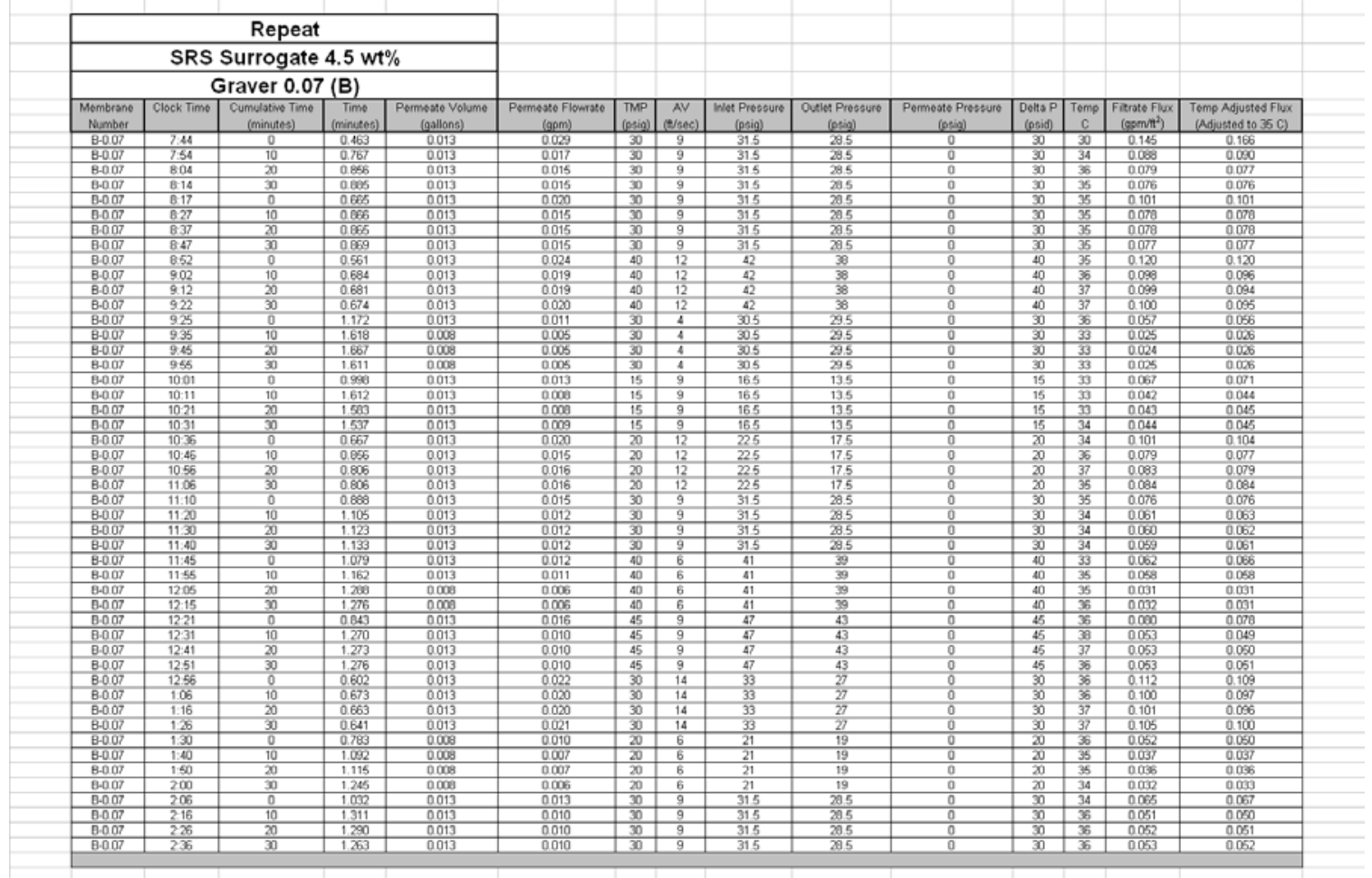

Table G-4. SRS Simulant $4.5 \mathrm{wt} \%$ Repeat (Mott $0.1 \mu \mathrm{m}$ ).

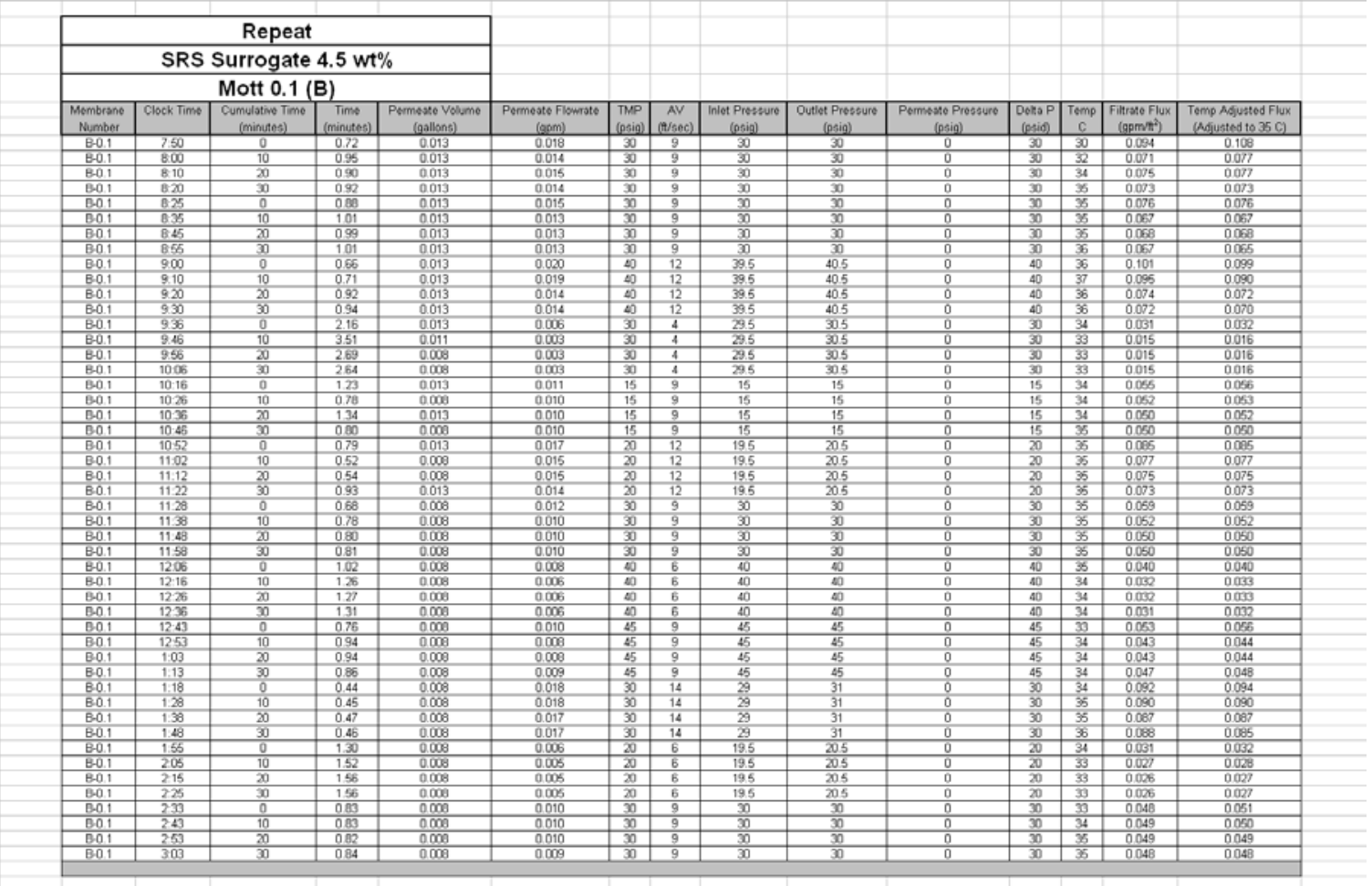


Table G-5. SRS Simulant 4.5 wt $\%$ Repeat (Pall $0.1 \mu \mathrm{m}$ ).

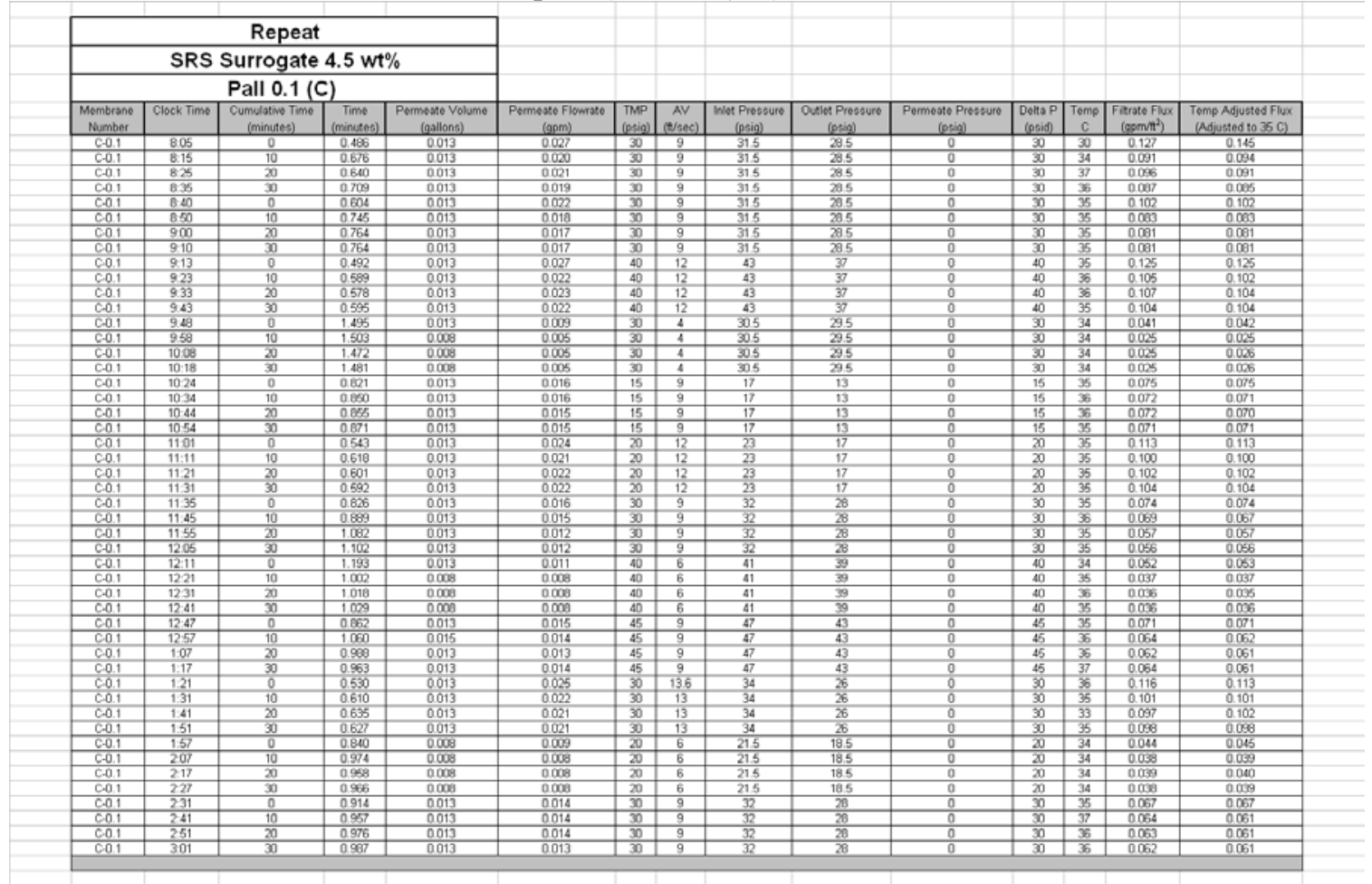


Appendix $\mathrm{H}$

SRS Simulant 0.06 wt $\%$ 


\section{Appendix $\mathrm{H}$}

\section{SRS Simulant $0.06 \mathrm{wt} \%$}

Table H-1. SRS Simulant 0.06 wt $\%$ (Graver $0.07 \mu \mathrm{m}$ ).

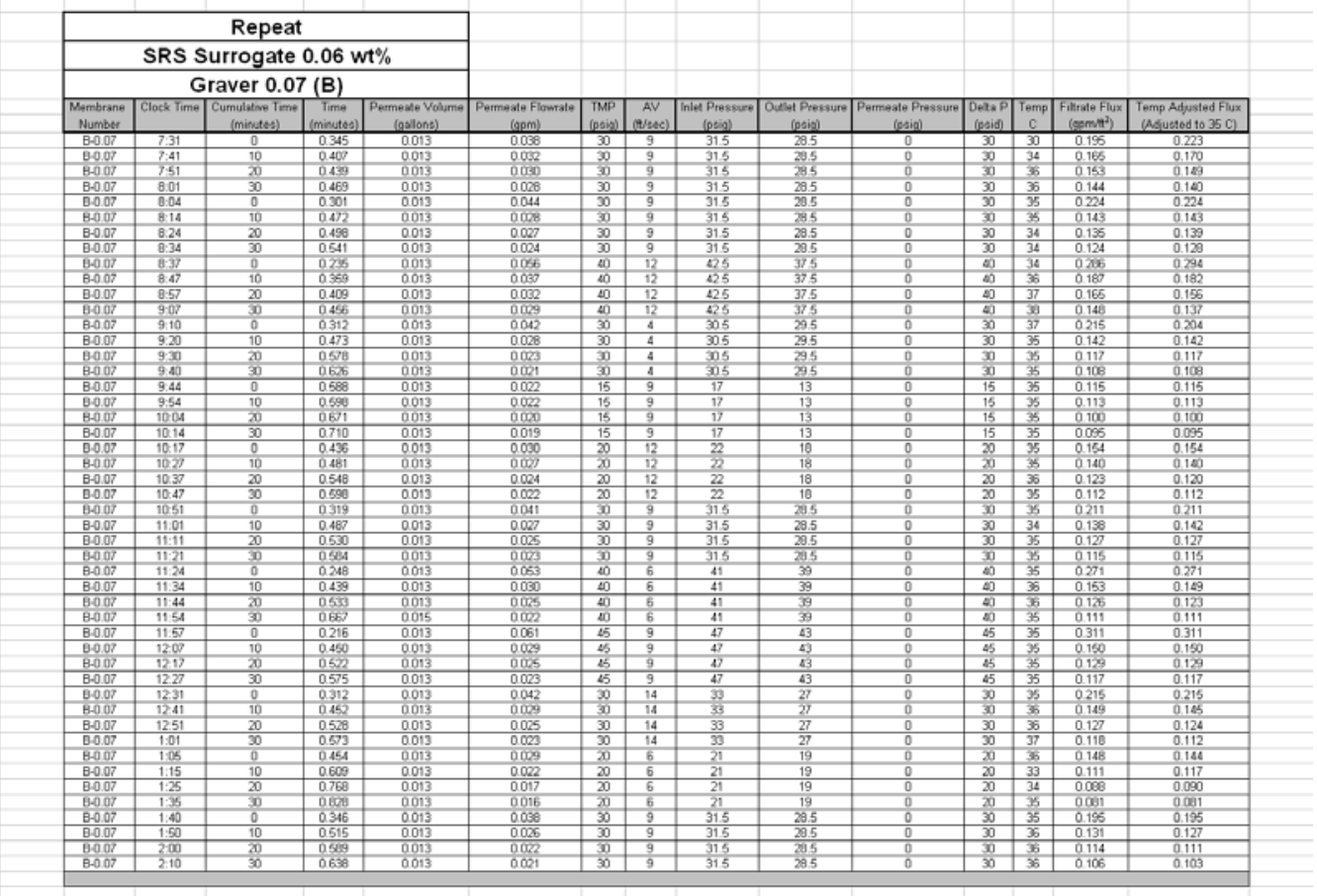

Table H-2. SRS Simulant 0.06 wt $\%$ (Mott $0.1 \mu \mathrm{m}$ ).

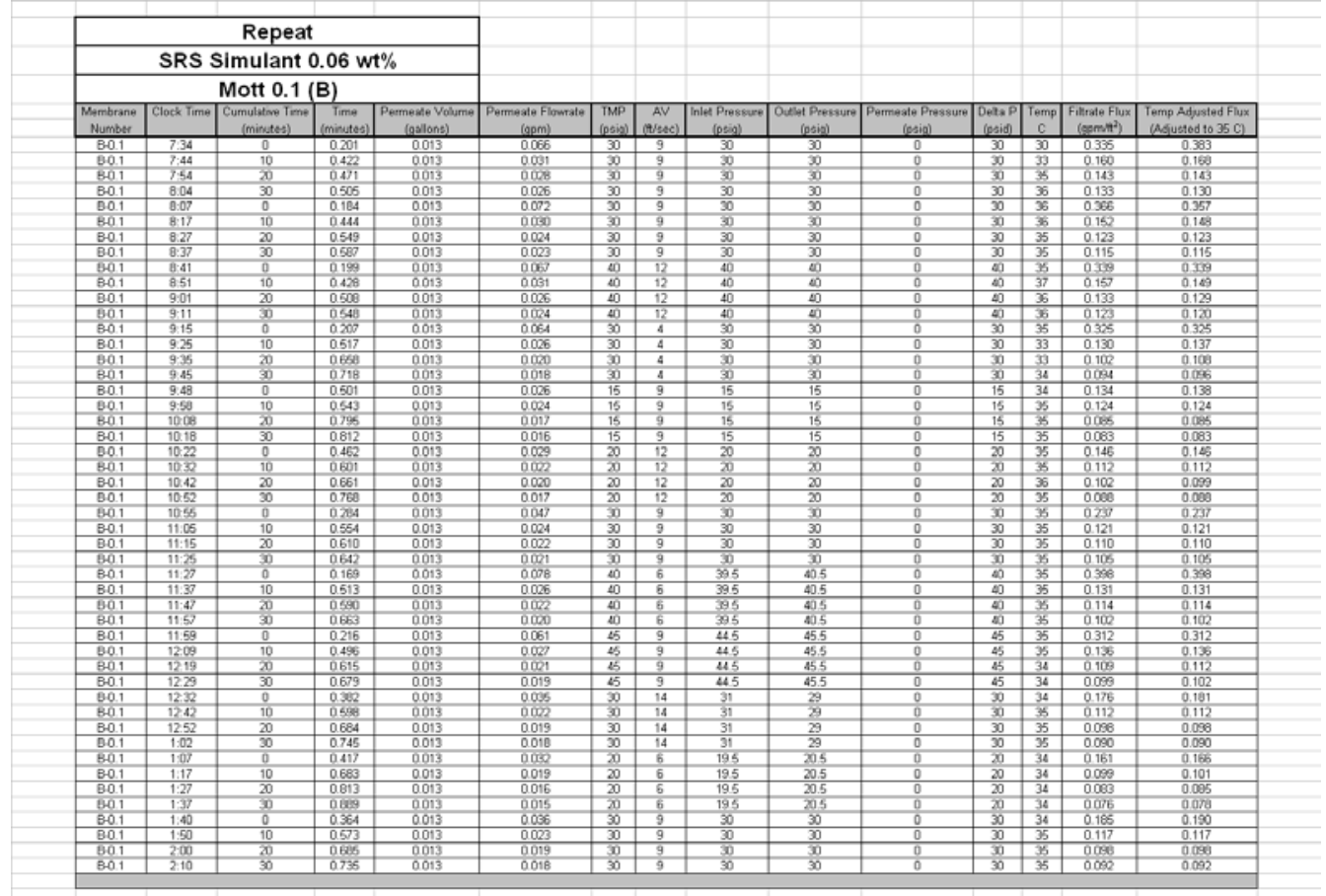


Table H-3. SRS Simulant 0.06 wt $\%$ (Pall $0.1 \mu \mathrm{m}$ ).

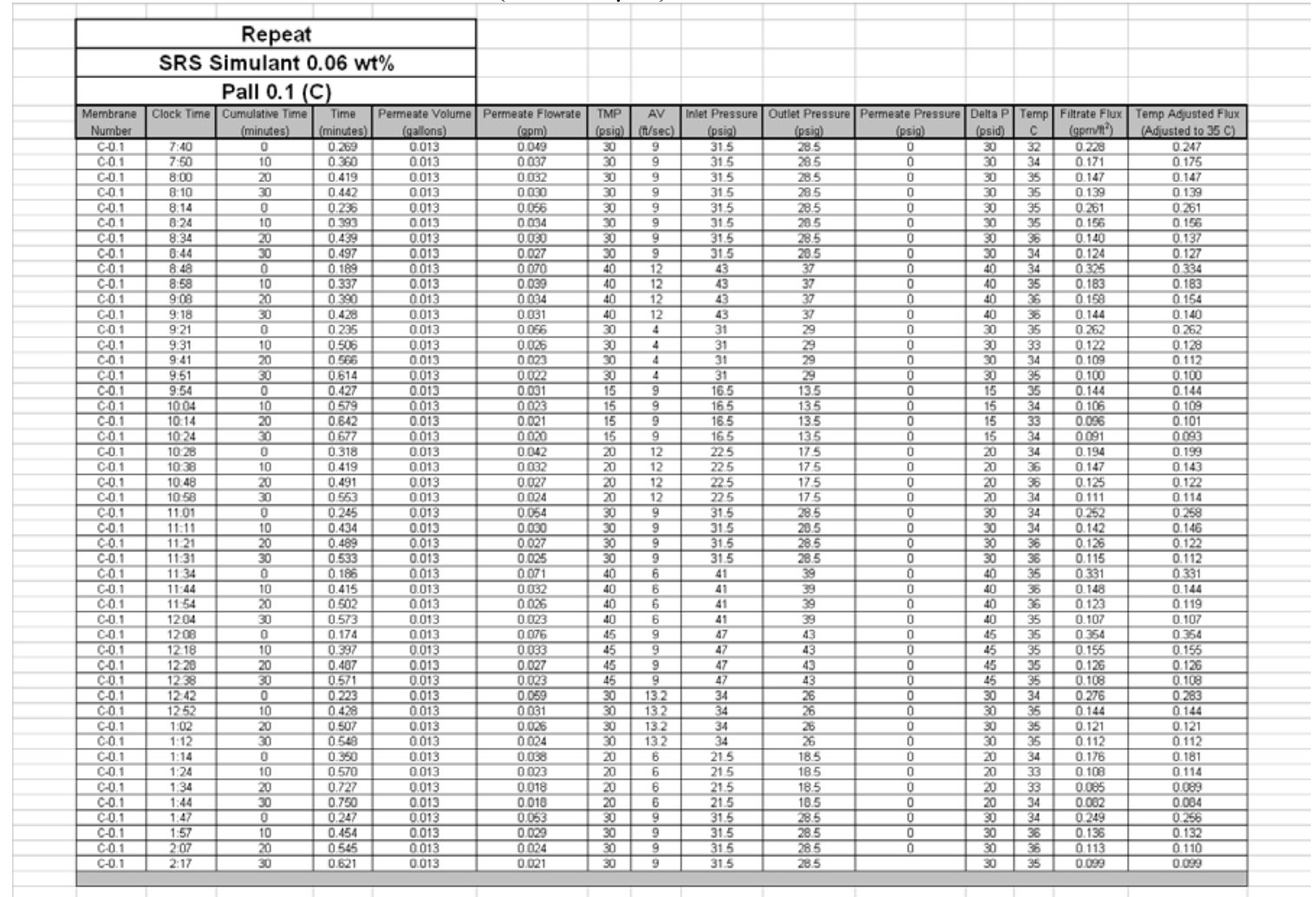




\section{Appendix I}

\section{Budgetary Quotes}




\section{Appendix I \\ Budgetary Quotes}

Table I-1. Budgetary quote for Pall membranes.

\section{BUDGETARY PRICE SHEET}

\section{WSRC Ultrafilter Retrofit Vessel and Filter Assembly}

Customer: Westinghouse Savannah River

Date: May 20, 2004

Item 1: (280) 96" AccuSep ${ }^{\circledR}$ Zirconia coated ( $0.1 \mu$ micron) membranes welded directly into the tubesheet comprising a combined filtration area of $231 \mathrm{ft}^{\wedge} 2$.

Item 2: $96 "$ AccuSep ${ }^{\circledR}(1.0 \mu$ micron $)$ membranes welded directly into the tubesheet.

Price [Item 1] Pall will complete the work as proposed for the budgetary price of $\$ 100,000.00$

[Item 2] Pall will complete the work as proposed for the budgetary price of $\$ 140,000.00$

\section{Validity}

Pricing is valid for a period of 90 -days from noted date. If a formal purchase order or executed contract is not received within the 90-day period, both the pricing and delivery schedule are subject to review and adjustment.

\section{Delivery}

16 Weeks ARAD

\section{Taxes and Duties}

Taxes are not included in the pricing. Any taxes, duties, tariffs of any type are for the account of the Purchaser.

\section{Terms of Payment}

$50 \%$ Upon Receipt of Order

$50 \%$ Delivery 
Table I-2. Budgetary quote for GKN membrane.

May 20, 2004

KemTEK, Inc.

21 Colonial Ave.

Haddonfield, NJ 08033

Attn.: Mr. Carl Gakeler

Subject: SRS BUDGET QUOTE---

Ref.: INEEL ---(1)FILTER 18" HyPULSE LSX Vessel

Refer to our ----DCF ref.\#040502----

Carl:

With reference to your request for a budgetary price for subject 18" Filter Vessel:

DCF price to design and build with reference to DOE SRS 200S AREA drawing (Defense

Waste Processing Facility, Late Wash Facility) for Cross Flow Filter Modifications, Plan and Sections S511-205-030-00-F, as well as, referred to reference drawing \#D7020346:

Price for one vessel as follows:

DCF design/manufacturing engineering ----------------------optional---------- \$200,000.

DCF vessel and GKN supplied tubes $\$ 275,000$.

Total $\$ 475,000$.

\section{Ref. Drawing \#D7020346 please note the following:}

Notes 1,2, \& 3 ----Vessel to be designed, built, and stamped to ASME SECTION VIII, DIV I in accordance with NQA-1 requirements.

Note \#4----Final assembly --Westinghouse SRS Engineering Stds ---not applicable.

Note \#5----Welding to be in accordance ASME CODE SECT VIII, DIV I, as applicable.

(Welding procedures, welders \& welder operators qualified (prior to fabrication) in accordance with SECT IX of ASME CODE. Reference to Westinghouse SRS Engineering Stds--- not applicable).

Tubes to be furnished by GKN — tubes to be manufactured and welded in accordance with DIN and GKN MFG STDS.

Note \#12---Shipping is for a domestic box.

Notes \#16, 22 \& 23---Not applicable.

Price excludes tube design engineering costs (by KemTEK/GKN)

Price is exclusive of sales, use and all other taxes

Price is good for a period of 30 days from date of quotation.

Delivery: to be determined at time of order placement, subject to material availability lead times and DCF production scheduling. 
FOB Florence, NJ (Freight costs by others)

Terms: To be determined, mutually agreed upon.

Should you have any questions or comments please do not hesitate to contact me.

Sincerely,

Robert Sarraiocco

Business Development Manager

DC Fabricators Inc. 
Carl Gakeler

21 Colonial Avenue

Haddonfield NJ 08033

Phone: 856-428-9332

Fax: $\quad 856-428-9206$

www.kemtekni.com

carl@kemtekni.com

\section{Fax}

To: NICK MANN

Company: INEET,

Fax: $208-526=3499$ 2. $2-526-1$

Phone: 208-526-8644

Re: CROSS FLOW ULTRA FILTER

\section{K e m T E K}

From: Cart Gakeler

Date: MAY 20, 2004

Pages: 3<smiles>C=[Te][Te][Te][Te][Te]</smiles>

18" DIAMETER

NICK :

BUDGET PRICE IS ATTACHED.

TO BE SAFE, I HAVE INCLUDED SPECIFICATIONS OF ASME CODE AND NQA-1. THIS PRICE IS SIMILAR THE HANFORD FILTERS EXCEPT THE ENGINEERING COST IS NOT APPORTIONED OVER SIX (6) FILTERS. IN THE EVENT MULTIRLE FILTERS WOULD BE REQUIRED, THE ENGINEERING COST OF $\$ 200,000.00$ WOULD BE APPORTIONSD.

I COULD NOT PREDICT THE WESTINGHOUSE STANDARDS THEREFORE HAVE TAKEN EXCEPTION TO THEM, BUT HOPEFULLY HAVE THEM COVERED TO SOME EXTENT

THE QUOTE IS TO DRAWING 7020346 REV D WHITE THE OVERALL DIMESIONS AND LAYOUT ARE TO S511-205-030-00-F.

NICK, I HOPE THIS PRESENTATION AND QUOTE WIIL BE SUFFICIENT TO YOUR CURRENT NEEDS.THE TUBES ARE GKI AS TYPE TUBES.

BEST REGARDS, 
Table I-3. Budgetary quote for Graver membranes.

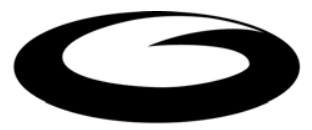

Graver Technologies
Graver Technologies, Inc. 200 Lake Drive Glasgow, DE 19702.3319

Toll Free: $800 \cdot 249 \cdot 1990$

Tel: $302 \cdot 731 \cdot 1700$

Fax: $302 \cdot 731 \cdot 1707$

\section{Budget QUOTATION}

DATE: May 24, 2004

PREPARED FOR:

INEEL

Idaho Falls, ID. 83415
QUOTATION \# C6034

SUBMITTED FROM:

Graver Technologies Inc.

200 Lake Drive

Glasgow, DE 19702 USA

Attn: Mr. Nick Mann - AST; Re: SCEPTER ${ }^{\circledR}$ MF Module for Savannah River

Your interest in Graver Technologies products is appreciated and we propose to furnish you:

\begin{tabular}{|c|c|c|c|c|}
\hline ITEM \# & QTY & DESCRIPTION & Price Each & TOTAL \\
\hline $1 \mathrm{~A}$ & 1 & $\begin{array}{l}\text { Graver Technologies Scepter microfiltration membrane } \\
\text { module model no. 12C-750A-10P2. This is a two- } \\
\text { pass, } 10 \text { foot ( } 3 \text {-meter) porous tube length module } \\
\text { designed for horizontal mounting. Provides } \\
\text { approximately } 237.5 \text { sq.ft. (22 } \mathbf{~ m}^{2} \text { ) of membrane area } \\
\text { rated at } 0.1 \text { microns. Contains quantity } 126 \text { ( } 63 / \text { pass) } \\
\text { tubular membranes having a nominal inner diameter of } \\
\mathbf{0 . 7 2} \text { inches ( } 18.3 \mathrm{~mm}) \text {. Module shell material of } \\
\text { construction is } 316 \mathrm{~L} \text {. Tubes are } 316 \mathrm{~L} \text { with TiO } \\
\text { membrane. ASME code designed and stamped for } 200 \\
\left.\text { psig ( } 13.8 \text { bar) at } 400^{\circ} \mathrm{F} \text { ( } 204^{\circ} \mathrm{C}\right) \text {. Process connections } \\
\text { to be standard pipe size weld stubs (or other as } \\
\text { mutually agreed). Sizes, quantity, and orientations to } \\
\text { be determined. All welded construction. A circulation } \\
\text { flowrate of } \mathbf{4 7 9} \text { to } 718 \mathrm{gpm} \text { would provide a crossflow } \\
\text { velocity of } 6 \text { to } 9 \mathrm{ft} / \mathrm{sec} \text {. }\end{array}$ & $\$ 45,600.00$ & $\$ 45,600.00$ \\
\hline $1 \mathrm{~B}$ & 1 & $\begin{array}{l}\text { Graver Technologies Scepter microfiltration membrane } \\
\text { module model no. 10C-375A-10P. This is a one-pass, } \\
10 \text { foot (3-meter) porous tube length module designed } \\
\text { for horizontal mounting. Provides approximately } 312 \\
\text { sq.ft. }\left(29 \mathrm{~m}^{2}\right) \text { of membrane area rated at } 0.1 \text { microns. } \\
\text { Contains } 312 \text { tubular membranes having a nominal } \\
\text { inner diameter of } 0.38 \text { inches }(9.65 \mathrm{~mm}) \text {. Module shell } \\
\text { material of construction is } 316 \mathrm{~L} \text {. Tubes are } 316 \mathrm{~L} \text { with } \\
\mathrm{TiO} \text { membrane. ASME code designed and stamped for } \\
200 \text { psig ( } 13.8 \text { bar) at } 400^{\circ} \mathrm{F}\left(204^{\circ} \mathrm{C}\right) \text {. Process } \\
\text { connections to be standard pipe size weld stubs. Sizes, } \\
\text { quantity, and orientations to be determined. All welded } \\
\text { construction. A circulation flowrate of } 659 \text { to } 998 \mathrm{gpm} \\
\text { would provide a crossflow velocity of } 6 \text { to } 9 \mathrm{ft} / \mathrm{sec} \text {. }\end{array}$ & $\$ 58,800.00$ & $\$ 58,800.00$ \\
\hline
\end{tabular}




\begin{tabular}{|c|c|c|c|c|}
\hline $1 \mathrm{C}$ & 1 & $\begin{array}{l}\text { Graver Technologies Scepter microfiltration membrane } \\
\text { module model no. } 12 \mathrm{C}-750 \mathrm{~A}-10 \mathrm{P} \text {. This is a one-pass, } \\
10 \text { foot (3-meter) porous tube length module designed } \\
\text { for horizontal mounting. Provides approximately } 262 \\
\text { sq.ft. }\left(24.3 \mathrm{~m}^{2}\right) \text { of membrane area rated at } 0.1 \text { microns. } \\
\text { Contains } 139 \text { tubular membranes having a nominal } \\
\text { inner diameter of } 0.72 \text { inch }(18.3 \mathrm{~mm}) \text {. Module shell } \\
\text { material of construction is } 316 \mathrm{~L} \text {. Tubes are } 316 \mathrm{~L} \text { with } \\
\mathrm{TiO} \text { membrane. ASME code designed and stamped for } \\
200 \text { psig ( } 13.8 \text { bar) at } 400^{\circ} \mathrm{F}\left(204^{\circ} \mathrm{C}\right) \text {. Process } \\
\text { connections to be standard pipe size weld stubs. Sizes, } \\
\text { quantity, and orientations to be determined. All welded } \\
\text { construction. A circulation flowrate of } 1056 \text { to } 1585 \\
\text { apm would provide a crossflow velocity of } 6 \text { to } 9 \mathrm{ft} / \mathrm{sec} \text {. }\end{array}$ & $\$ 44,000.00$ & $\$ 44,000.00$ \\
\hline
\end{tabular}

-- An approval drawing will be provided for your review and comments prior to manufacture. --

Terms: $\quad$ Twenty-five percent on drawing approval; Balance Net 30 days after shipment with approved credit. Approval drawing within 10 days of order.

FOB: $\quad$ Shipping Point - Robbinsville, NJ.

Freight: $\quad$ PP and add, or Collect. By dedicated air-ride flat bed truck.

Shipment: $10-12$ weeks after drawing approval, but dependent on shop load at time of order.

Validity: This quotation is valid for purchase for 60 days.

To place an order call Scott Wittwer at (302) 731 - 3539.

Subject to enclosed terms unless otherwise stated above or in any documents attached.

\begin{tabular}{c} 
PREPARED BY \\
Scott Wittwer \\
\hline Scott Wittwer \\
Product Manager
\end{tabular}


Table I-4. Budgetary quote for the Mott $0.1 \mu \mathrm{m}$ membrane (personal email, 06-23-04).

Michael,

The actual quote for the 0.1 Mott filter was $\$ 255,000+\$ 15,000$ for QA related documentation and inspections for a total cost of $\$ 270,000$. This quote was effective in January 2004 . We expect to see an escalation of the cost based on rising costs for stainless steel.

The $\$ 27,300$ for modification of the factory supplied filter to add elbows, Hanford nozzles, balance it, etc. should be a COMMON cost for any vendor's filter we purchase. However, keep in mind that the facility was designed specifically around a Mott filter with certain length tubes. I would expect the modification costs to be higher for any vendor's filter that was different in size, etc (e.g. different length standard tubes resulting in a fatter or longer tube bundle to get the same filter area.). The existing jumpers in the Cell are designed to fit the exact geometry of the Mott filter. If we use a different vendor and the nozzle locations are different by any dimensional amount, then at least 4 or more jumpers will have to modified at considerable cost $(\$ 100,000$ or more).

The estimate of $\$ 30,000$ for $512 S$ operational costs to install the filter would also be a common cost for any vendor's filter.

Please call me Michael and we can discuss how you intend to use this information in your comparisons of Filter Vendors. I want to make sure we are not talking apples and oranges when the filter vendors are compared. The cost numbers I saw for the "other vendors" seemed too low for a complete filter vessel.

---- Forwarded by E Seufert/WSRC/Srs on 06/23/2004 08:44 AM ----

James Lovekamp/BSRI/Srs

06/23/2004 08:14 AM 